\title{
ARCTIC NETWORK BUILDERS: THE ARCTIC COAL COMPANY'S OPERATIONS \\ ON SPITSBERGEN AND ITS RELATIONSHIP WITH \\ THE ENVIRONMENT
}

By

CAMERON C. HARTNELL

\author{
A DISSERTATION \\ Submitted in partial fulfillment of the requirements \\ For the degree of \\ DOCTOR OF PHILOSOPHY \\ (Industrial Heritage and Archaeology) \\ MICHIGAN TECHNOLOGICAL UNIVERSITY \\ 2009
}

Copyright (C) Cameron C. Hartnell 2009 
This thesis, “Arctic Network Builders: The Arctic Coal Company's Operations on Spitsbergen and its Relationship with the Environment," is hereby approved in partial fulfillment of the requirements of the Degree of DOCTOR OF PHILOSOPHY in the field of Industrial Heritage and Archaeology.

\section{SOCIAL SCIENCES DEPARTMENT:}

Industrial Heritage and Archaeology

Signatures:

Dissertation Advisor

Dr. Patrick Martin

Department Chair

Dr. Patrick Martin

Date 


\begin{abstract}
In 1906, two American industrialists, John Munroe Longyear and Frederick Ayer, formed the Arctic Coal Company to make the first large scale attempt at mining in the high-Arctic location of Spitsbergen, north of the Norwegian mainland. In doing so, they encountered numerous obstacles and built an organization that attempted to overcome them. The Americans sold out in 1916 but others followed, eventually culminating in the transformation of a largely undeveloped landscape into a mining region.

This work uses John Law's network approach of the Actor Network Theory (ANT) framework to explain how the Arctic Coal Company built a mining network in this environmentally difficult region and why they made the choices they did. It does so by identifying and analyzing the problems the company encountered and the strategies they used to overcome them by focusing on three major components of the operations; the company's four land claims, its technical system and its main settlement, Longyear City. Extensive comparison between aspects of Longyear City and the company's choices of technology with other American examples place analysis of the company in a wider context and helps isolate unique aspects of mining in the high-Arctic. American examples dominate comparative sections because Americans dominated the ownership and upper management of the company.
\end{abstract}




\section{TABLE OF CONTENTS}

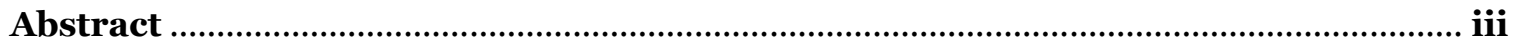

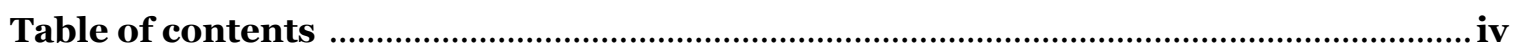

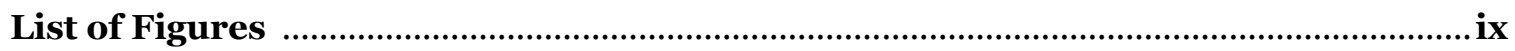

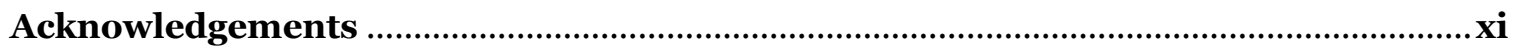

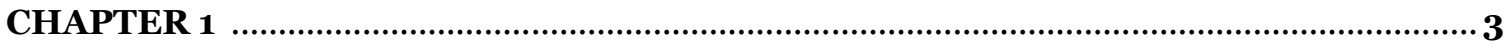

\section{Introduction}

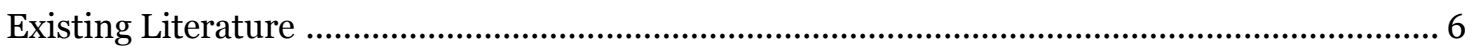

Objectives of the Dissertation and Theoretical Background ….................................................... 11

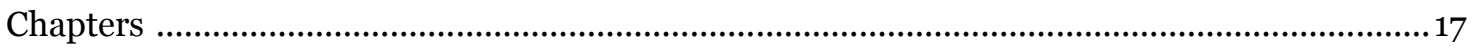

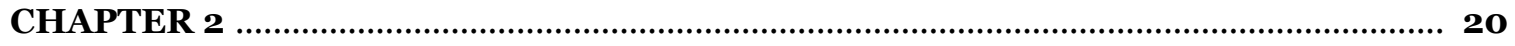

Spitsbergen's Environmental, Historical and Industrial Context

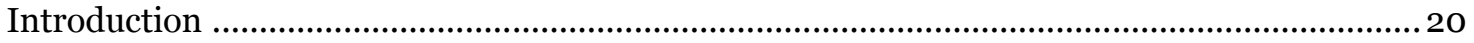

The Environment and Political Status of Spitsbergen ............................................................ 20

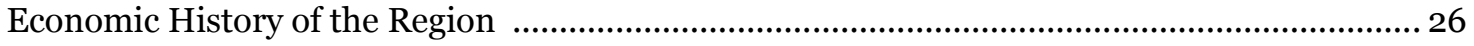

Northern Scandinavian Industrialization ............................................................................ 26

The Human History of Spitsbergen ....................................................................................... 31

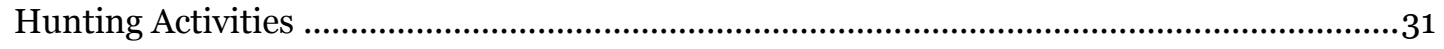

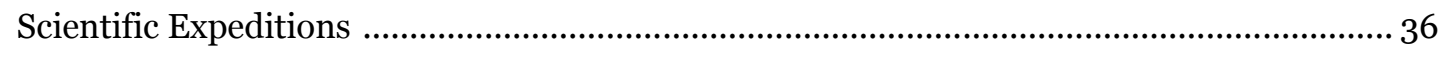

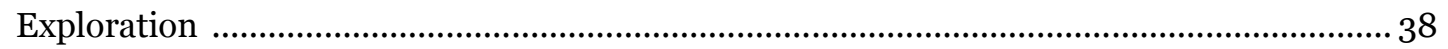

Political History of Spitsbergen ........................................................................................... 40

Spitsbergen's Coal Fields before the Coal and Mineral Rush ................................................. 43

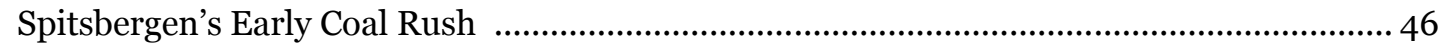

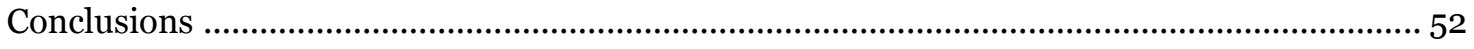




\section{The Establishment of the Arctic Coal Company}

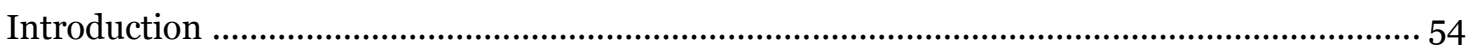

The Origins of the Arctic Coal Company …………................................................................... 55

Ayer and Longyear's Landscape Strategy on Spitsbergen ....................................................... 66

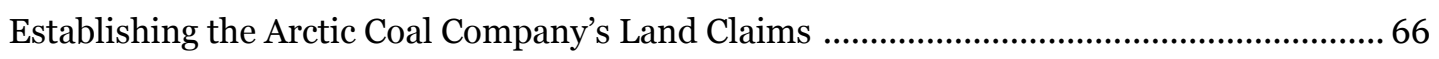

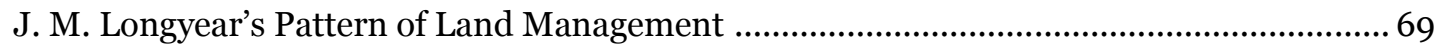

Bringing Longyear's Land Management Approach to Fruition ..............................................75

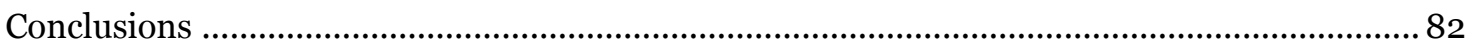

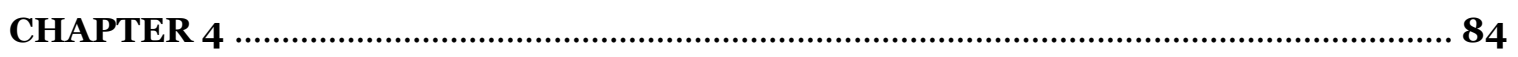

The Evolution of the Arctic Coal Company's Technical System

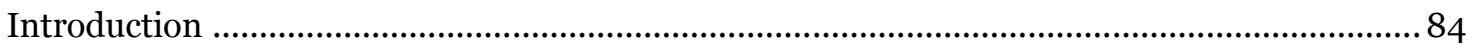

The Evolution of the Arctic Coal Company's Technical System ................................................ 85

Phase 1 (1905-1908): Establishment of Core Components .................................................... 85

Phase 2 (1909-1911): An Operational Coal Mine .................................................................. 96

Phase 3 (1912-1916) Americanizing the Operations ............................................................... 103

Analysis of Individual Actants in the Network .......................................................................110

The Coal Storage and Delivery System ………................................................................110

Non-Technical Aspects of the Organization .......................................................................... 113

Commercial Shipping Issues ..................................................................................... 114

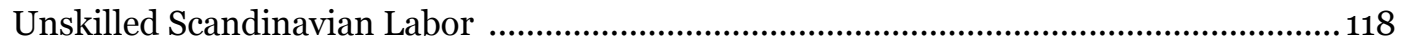

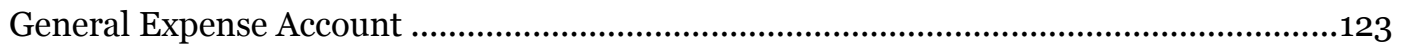

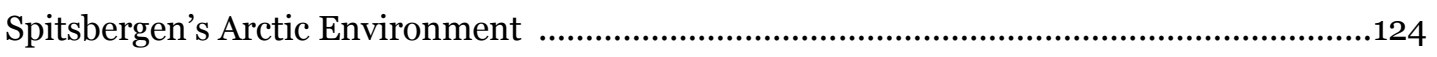

The Operation as both System and Collection of Individual Parts ...........................................127

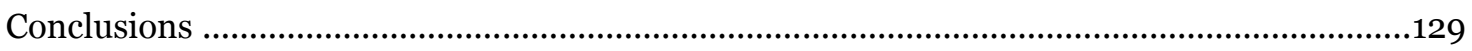




\section{The Expansion of Longyear City}

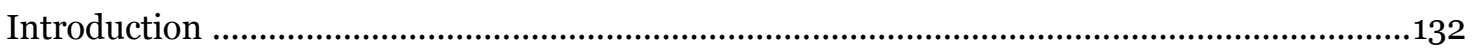

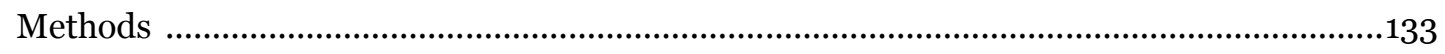

The Evolution of Longyear City ..........................................................................................135

Phase 1 (1905 - 1908): The Establishment of Longyear City ...............................................135

Phase 2 (1909 - 1911): The Expansion of Longyear City .......................................................147

Phase 3 (1912-1916): Expanding the City …………….........................................................154

Broad View of the Development of Longyear City ...................................................................164

Comparison with Company Town Practice in the United States ............................................ 171

Contemporary American Attitudes Towards Company Housing ….....................................172

Contemporary American Industrial Housing Types ...........................................................178

Comparison with the Kennecott Mill Town …….................................................................. 184

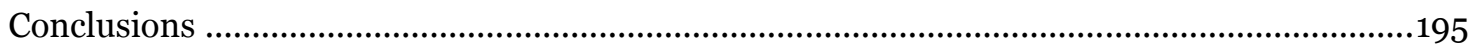

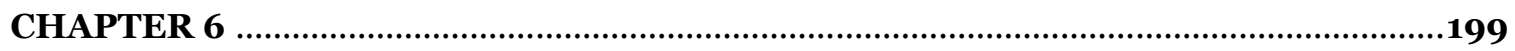

\section{Comparison of the Arctic Coal Company with Typical American Mining Practice} Overseas

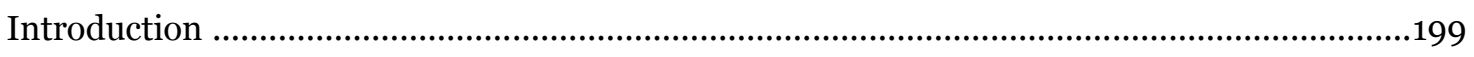

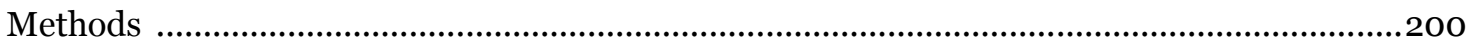

Overview of Approaches used by the Arctic Coal Company ................................................... 201

The Pattern of American Mining Companies Overseas ........................................................... 207

Two Major Elements of American Mining Adopted Overseas .............................................. 207

The California Gold Mill ............................................................................................. 207

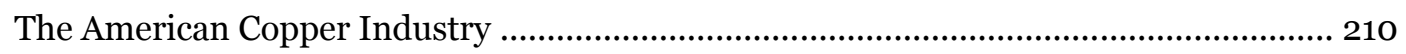

American Mining Companies in the Americas .....................................................................213

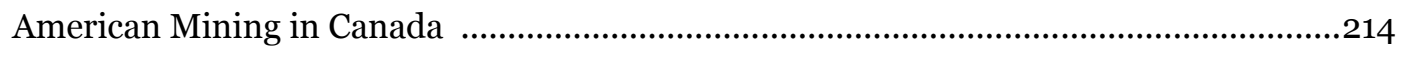

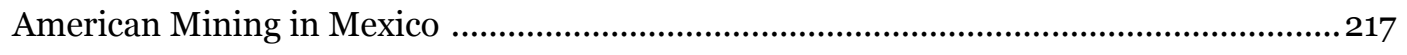

American Mining in the Caribbean, Central and South America .....................................221 
American Mining Outside the Americas ............................................................................. 225

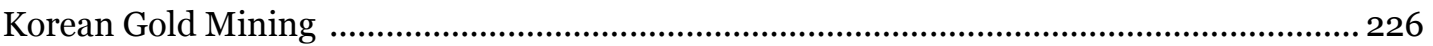

The Oriental Consolidated Mining Company …............................................................... 227

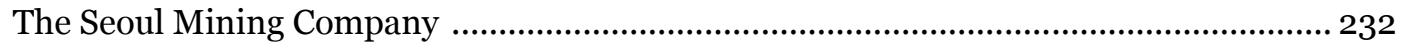

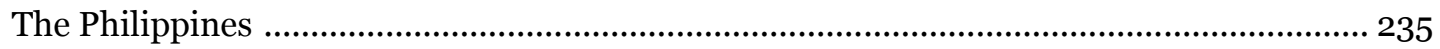

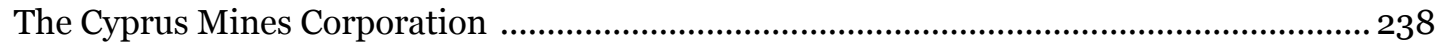

Forminière / The American Congo Company ……............................................................... 239

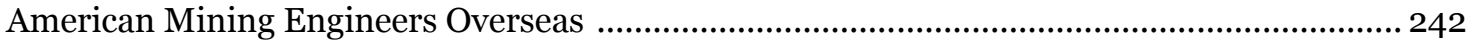

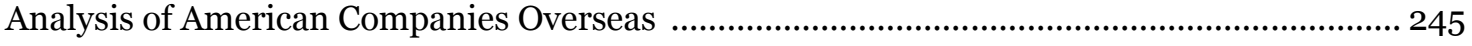

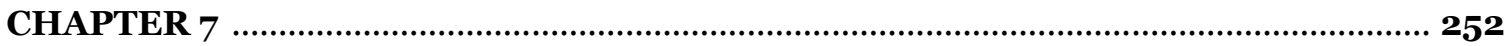

\section{The Heritage Significance of Arctic Coal Company Remains}

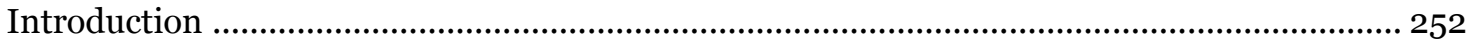

Heritage Legislation on Svalbard .................................................................................... 253

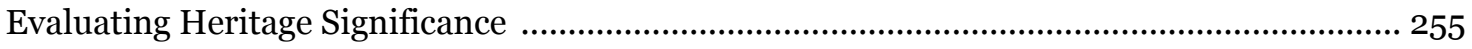

Historic Significance of the Arctic Coal Company's efforts .................................................... 257

The First Major Coal Mining Operation on Spitsbergen ..................................................... 257

Part of Spitsbergen’s Longest Lived Coal Mining Effort ....................................................... 258

The Arctic Coal Company's Legacy on Spitsbergen ............................................................. 259

Legacy to the Store Norske Spitsbergen Kulkompani ...................................................260

Legacy to other Spitsbergen Mining Operations ............................................................... 264

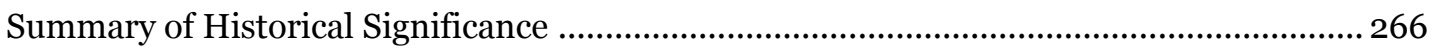

Significance of the Physical Remains of the Arctic Coal Company ............................................ 267

Historic Significance of the Remains as a group ................................................................. 267

Significance of Individual Parts of the Remains ..................................................................... 269

Remains of the Company's Land Claims …......................................................................... 269

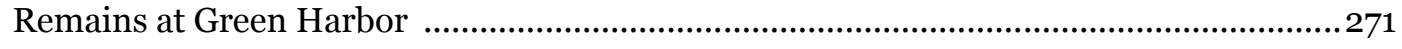

Remains of Geologic Testing and Mapping on Advent Bay ........................................... 274 
Old Longyear City …....................................................................................................277

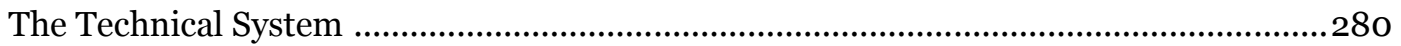

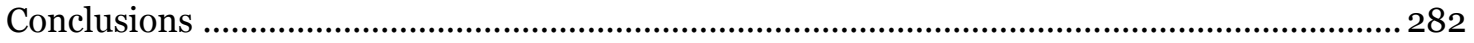

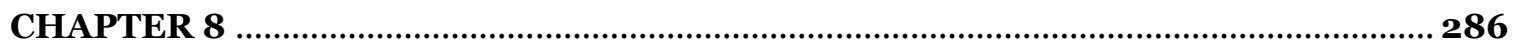

Conclusions

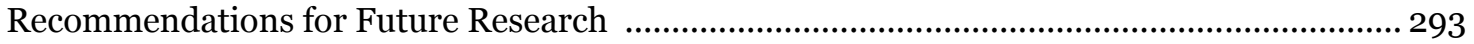

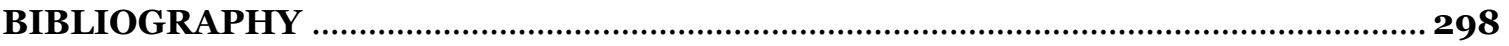

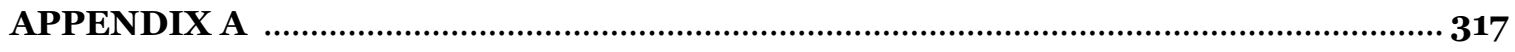

Archives and Data Sources Related to the Arctic Coal Company

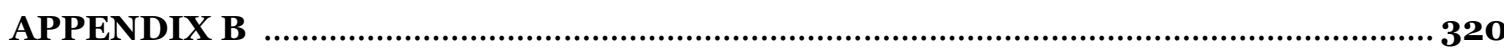

Permissions for Copyrighted Material 


\section{LIST OF FIGURES}

Figure 2.1 Map of water currents around the Arctic .................................................24

Figure 2.2 Map of Spitsbergen and Scandinavia ......................................................29

Figure 2.3 Map of West Spitsbergen showing known coal lands .................................34

Figure 2.4 Map of the Diana Coal Mine ....................................................................45

Figure 2.5 Illustration of the Diana Coal Mine .........................................................46

Figure 2.6 Section of 1903 Trondhjem-Spitsbergen Kulkompagni map ....................49

Figure 2.7 Grönvold's proposed design for a coal mining operation on Advent Bay $\ldots .50$

Figure 3.1 1913 Arctic Coal Company land claim map ..............................................68

Figure 3.2 Map of the western Lake Superior region ….............................................70

Figure 4.1 Map of the test-pits of southern Advent Bay ..............................................88

Figure 4.2 1912 map of the Arctic Coal Company operations ….................................90

Figure 4.3 1908 photograph of the wharfing and storage area …..............................92

Figure 4.4 1908 photograph of Mine 1 and coal hopper …......................................94

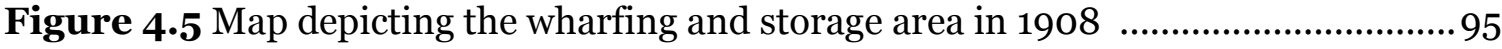

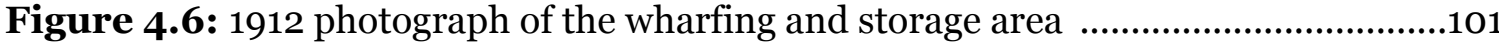

Figure 4.7 Map depicting the wharfing and storage area in 1911 .............................102

Figure 4.8 1913-1915 photograph of the wharfing and storage area ..........................108

Figure 4.9 Map depicting the wharfing and storage area in 1915 ..............................109

Figure 5.1 1906 photograph of the temporary settlement on Advent Bay .................. 136

Figure 5.2 1908 photograph of Longyear City ….................................................... 139

Figure 5.3 1913 photograph of the staff house …....................................................140

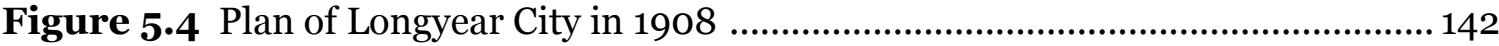

Table 5.1 Table of the housing of Longyear City in 1908 ......................................... 144 
Figure 5.5 plan of Bunkhouse \#3, built in 1908

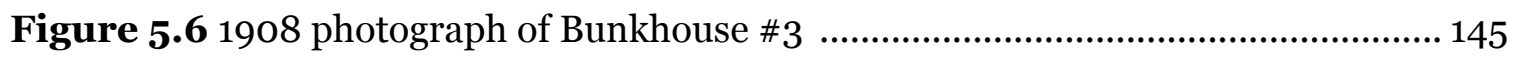

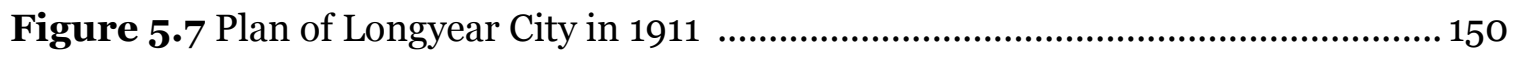

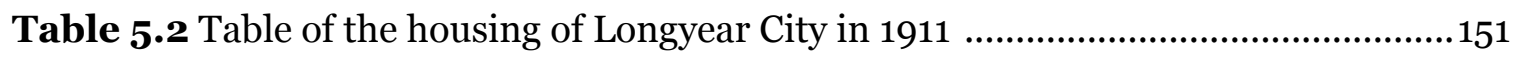

Figure 5.8 Plan of boarding houses \#9, \#11, \#13, built in $1910 \quad$................................ 152

Figure 5.9 1910-1911 photograph of Longyear City ................................................. 153

Table 5.3 Table of the housing of Longyear City in 1913. ......................................... 158

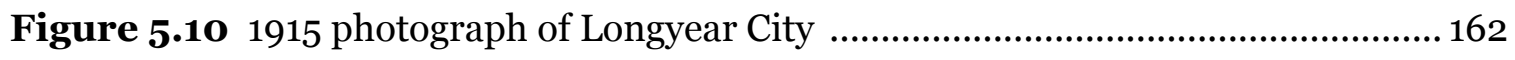

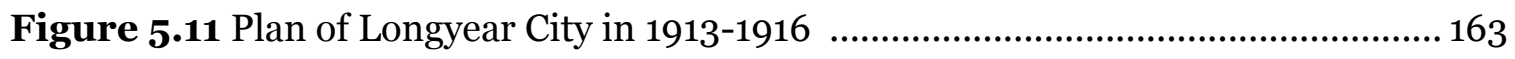

Table 5.4 Table showing the number of men employed each year of operation .......... 165

Table 5.5 Survey of worker nationalities at the Advent Bay Operations ..................... 166

Figure 5.12 Plan of the Kennecott Mill Town at the close of phase 1 in 1908 ............ 187

Figure 5.13 Plan of the Kennecott Mill Town at the close of phase 3 in 1915 ..............191

Figure 6.01 Plan of ACC mine 1, September 30, 1915 ...............................................206

Table 6.1 Estimates of US direct foreign investment for 1897, 1908 and 1914 ............ 214

Figure 7.1 Map of Arctic Coal Company hut remains on the Ice Fjord .......................270

Figure 7.2 Map of Arctic Coal Company remains at Green Harbor …........................273

Figure 7.3 2007 photograph of the south entry to Green Harbor Mine 1 ...................274

Figure 7.4 Map of test-pits and survey benchmarks on southern Advent Bay ............276

Figure 7.5 2003 photograph of southern part of Old Longyear City .........................278

Figure 7.6 Map of Arctic Coal Company remains in Longyear Valley .........................279

Figure 7.7 2004 photograph of the mine 1 complex ............................................... 281 


\section{ACKNOWLEDGEMENTS}

This dissertation was only possible because of the help and generosity of many. I would firstly like to thank my committee. Dr. Patrick Martin was always enthusiastic about the project and gave considerable effort to finding the funding I needed to get through these years, establishing links with other researchers and providing useful criticism of my work. Dr. Susan Martin had an enchantment with Spitsbergen after her own visit there that reminded me of what a unique place it is and how lucky I was to work on this project. Dr. Bruce Seely taught me everything I know about theory and his insistence on quality work drove me to work harder and get better. Dr. Dag Avango readily shared his extensive knowledge of Spitsbergen's history and gave many hours to discussions that enriched this work.

I want to thank all the people and institutions that provided money to the Michigan Technological University to undertake this project. To the Longyear Heirs and Christopher Longyear, the Store Norske Spitsbergen Kulkompani, the Svalbard Environmental Protection Fund and the National Science Foundation, thank you. Without your help, it would have been hard to achieve anywhere near as much as we did.

I am grateful and proud to be a member of LASHIPA, a research group that has ambitious goals and is, I think, well on the way to realizing them. My work was strengthened by the multi-national, multi-disciplinary team that makes up that group. In particular I would like to thank Ulf Gustafsson who went out of his way to help on several occasions. My teammate Seth DePasqual was not only an able research and survey partner who brought much to this project, but a good friend and travel partner. 
The staff of the Michigan Technological University archives gave continual assistance and interest in the project, for which I am grateful. I take your offer of perpetual free snacks seriously. The staff of all other archives I visited, particularly Rosemary Michelin of the J. M. Longyear Research Library, and everyone who took the time to donate and organize Arctic Coal Company materials are important reasons I could look so closely at the company's history. I am indebted to Jim Vohden, Rolfe Buzzell and Logan Hovis, and others who helped me find sources in Alaska when I was unable to visit myself, and to members of the Mining History Association that provided information on historic American mining overseas. At Michigan Tech, my appreciation extends to all my classmates and the friends I made while here. I would like to thank my parents and my family, who supported me even though they didn't understand why I studied this subject. My younger brother Toby not only came with me to visit the university before I'd decided to come but drove up to see me defend at the end. In return, I offer this work as an incentive to help him finish his own dissertation.

Finally, I would like to thank Dr. Elizabeth Norris. You were the first person I met in my Ph.D. and the journey of this work has always been shared with you. You listened daily to my overly detailed stories and helped me move forward when I wanted to stop. Finishing this work is a personal achievement, but it is second to being with you. 


\section{CHAPTER 1}

\section{Introduction}

From 1904, two American industrialists, J. M. Longyear and Fredrick Ayer, funded an ambitious attempt to mine coal in a largely undeveloped and untested region. Through 1916, the men expended over one million dollars establishing, expanding and refining the Arctic Coal Company's rough, inefficient system that continually leaked money. By the later years, the company's General Managers had succeeded in implementing the groundwork for a large operation, but that option fell outside Longyear and Ayer's financial willingness and they sold out at a loss. Mining stories like these are not uncommon. Companies have tried their luck on new mining ventures across the world with varying degrees of success. What makes the Arctic Coal Company's story most unique is its location at the highest latitude ever attempted for a mine of this scale.

The Arctic Coal Company's story is unusual and interesting in and of itself. Few readers will associate mining history and the Polar regions, or perhaps regard it as a more modern phenomenon, largely because views on the explorers, scientific studies, politics and native peoples have traditionally dominated Polar history. Only recently has research has begun to uncover the major role of technical facilities and industrial processes in the history of these isolated areas.

Resource exploitation, trade and technical systems have played a large part of the modern history of the Polar regions, forming the basis of much of the human presence there today. The trade in animal goods has attracted people to the Arctic and Antarctic for centuries. From the twelfth century onwards groups exploited Russia's northern 
Arctic zone for furs and animal goods. ${ }^{1}$ Sealers were the first people to land on and explore parts of Antarctica, from $1788^{2}$, and whalers explored and exploited most Polar waters around the world. 3 European efforts to find the North-West and North-East Passages from around the turn of the sixteenth century centered on the commercial goal of finding trade routes to eastern markets. ${ }^{4}$ It was only at the end of the nineteenth century that large scale facilities and operations became present in the Polar regions, dominating the character of human intervention from that time forward. Iron mining in Northern Sweden was the first industrial scale activity of the Arctic, 5 followed by mining in Norway, operations elsewhere in the Arctic and then the Antarctic. In 1929, Soviet Russia began implementing a huge Arctic development program that involved the coordinated installation of settlements and industries with new rail, shipping and air routes. ${ }^{6}$ During the 1950 s some governments funded major, technically advanced facilities ostensibly for the purposes of scientific enquiry and defense. At that time, the US, U.S.S.R./Russian and other governments erected major research bases across Antarctica, supported by technical systems such as power, transportation and communications. ${ }^{7}$ The US and U.S.S.R. governments funded major defense projects in

1 Vaughan, Richard, The Arctic: A History (Phoenix Mill: Sutton Publishing, 1994), 51-53. 2 Grattan, C. Hartley, 1963: The Southwest Pacific to 19oo, A Modern History: Australia, New Zealand, The Islands, Antarctica (Ann Arbor, Michigan: The University of Michigan Press, 1963).

3 Ellis, Richard, Men and Whales (NY: Alfred A. Knopf, 1991).

4 Vaughan, The Arctic, 54-76.

5 Brunnström, Lasse, Kiruna - A Swedish Mining City from the Turn of the Century (Umeå, Sweden: University of Umeå, 1981).

6 Smolka, H. P., 4o,ooo against the Arctic: Russia's Polar Empire (NY: William Morrow and Company, 1937) and Smolka, H.P., Soviet Development of the Arctic New Industries and Strategical Possibilities, International Affairs, 16, 4 (1937): 564-578.

7 Quigg, Philip W., Antarctica: The Continuing Experiment (Foreign Policy Association, 1985). 
the Arctic including the Distant Early Warning Line (Dew Line) put in place by the US and Canadian governments along the northern shore of North America, and nuclear submarines developed by the US military to travel in the Arctic Ocean.

The subject of Polar industrial history is appealing because it affords the possibility of asking different questions than those typically addressed, particularly surrounding the links between people and the Polar environment in the modern setting. Amongst the many that could be asked are: how did people interpret and change the Polar regions to suit their needs and how did those Regions change human practices? What role did technology play in that process? How is human change of the Polar regions different from that of other localities? Deficiencies exist in drawing out these questions are largely the result of predominant western perspectives of the Arctic, past and present, which tend to emphasize human separation from the environment.

Historic views of the frozen north routinely featured mystical and romantic backgrounds that make the environment seem almost unrecognizable, ${ }^{8}$ and this tendency still exists in our depictions of the Polar regions today. Accounts of the 'heroic era' show men valiantly attempting to pass through often uniquely extreme conditions. ${ }^{9}$ The explorer's interactions with the place are temporary and the extraordinary environment simply heightens the impact of the story. Historical studies of the native peoples of the Arctic have shown their intricate adaptations to the Arctic environment but often present the peoples as largely culturally independent and even alien to those of more southern

8 McGhee, Robert, The Last Imaginary Place: A Human History of the Arctic World (Oxford University Press, 2005), 105-108.

9 Most histories of the 'Heroic Era' follow this general course, such as Neatby, L. H., Conquest of the Last Frontier (NY: H. Wolff, 1966) and Nasht, Simon, The Last Explorer: Hubert Wilkins, Hero of the Great Age of Polar Exploration (NY: Arcade Publishing, 2005). 
cultures. ${ }^{10}$ The sense of separation between people and the Polar regions continues strongly today, although in different ways. In a welcoming information booklet for Spitsbergen, the Norwegian governor encourages visitors to experience one of the nature's last frontiers but emphasizes that the experience must be "on Nature's own terms." 11 Visitors and scientists alike can observe nature but are discouraged from interacting with it and generally forbidden to alter it. Governments apply that type of management approach across the Polar environments, driven by the need to protect pristine, non-human places. Contemporary television or film accounts of the regions have a fondness for the explorers, or of wild nature free of the 'corrupting' influence of people, where penguins and polar bears live outside the human sphere.

Recently, some have challenged these traditional perspectives by drawing people into the stories of place. Werner Herzog's recent film, Encounters at the End of the World, offers a refreshing glimpse of the people living in Antarctica and the human systems that allow them to exist there. ${ }^{12}$ In that film, Herzog seeks to understand the people who come to this desolate and isolated setting and why do they chose do so. Robert McGhee is an influential author who specifically draws together the numerous cultural groups to develop a rich human history of the Arctic. ${ }^{13}$ Industrial Polar history offers another avenue into critical environmental history questions.

10 McGhee, The Last Imaginary Place, 105-108.

11 The Governor of Svalbard, Svalbard: Experience Svalbard on Nature's own terms (Svalbard, Longyearbyen: Svalbard Reiseliv, 2006).

12 Herzog, Werner, dir. Encounters at the End of the World, Discovery Films, 2008.

13 McGhee, The Last Imaginary Place. 
The Arctic Coal Company is historically important because it connected humans with a high-Arctic environment in a way that had never been tested. They mined and sold a bulk commodity en mass through technical systems that coordinated with large groups of men and the local environmental conditions. Unlike the depictions of the heroic explorers that emphasize isolation, improvisation, personal perseverance and temporariness, the Arctic Coal Company's industrial system required reliability, predictability, repeatability and regularity. The history is even more relevant because others built upon their system to develop the Spitsbergen that exists today.

Answering questions on how people have related with the Polar environment is critical to prepare for increasing human involvement in the future. Scientists now almost universally recognize that climate change is warming the Polar regions and reducing its ice pack. These changes provide increasing potential for introducing ever more human systems there, such as regular shipping lanes across the Arctic Ocean and exploitation of formerly inaccessible resources. To prepare for these possibilities, discussions about change need to recognize how human systems work in Polar settings and the potential geopolitical implications of those actions. In this light, industrial histories can provide valuable perspectives on how the Polar environment affects the social, technical, political and commercial aspects of industrial systems introduced there.

The research group LASHIPA (LArge Scale HIstoric exploitation of Polar Areas) formed in 2004 explicitly to confront historic research deficiencies by considering the role of industrial enterprises in Polar history. ${ }^{14}$ The overall aim of the LASHIPA project is to explain the deployment of industrial processes in the Polar regions from the seventeenth

14 The LASHIPA website provides information on the organizations makeup and ongoing activities: LASHIPA Home Page, http://www.lashipa.nl/ (May 18, 2008). 
century onward and describe its geopolitical consequences and impact on the natural environment. The group seeks to move away from the nation-based perspectives utilized by most historical research by drawing on researchers from around the world to develop internationally comparative explanations. To do so, it has engaged with universities, organizations and individuals in Great Britain, Sweden, Norway, the Netherlands, Russia and the United States, each of which has unique access to historical resources and varying perspectives on the past. The Michigan Technological University (MTU) is the American representative to the group that has to date focused on historic actions of the Arctic Coal Company on Spitsbergen. The study that formed the basis for this dissertation grew out of an MTU/LASHIPA archaeological survey of Arctic Coal Company remains on Spitsbergen made in 2004. The author joined that group in 2005 and collaborated with them on this project as well as others related to the history of Spitsbergen.

\section{Existing Literature}

Several historical works on the Arctic Coal Company already exist. This dissertation builds on these works and considers a major aspect of the company's history that remains to be fully explored; the physical evolution of the company on the landscape and its implications. In 1922, Nathan Haskell Dole published his two volume narrative on the company. ${ }^{15}$ Its title "America in Spitsbergen: The Romance of an Arctic Coal Mine” reveals something of its goal, to cast the American mining industrialists in the 'heroic era' by presenting their activities in similar ways to those commonly used for the explorers. His account explores the experience of developing and running the company 
from the perspective of the American management, largely based on company reports, letters and journals and existing documentation with little analysis of his own. He presents all the major aspects of the company, such as technology, labor, the Arctic environment and the surrounding political landscape, often with detailed descriptions, typically from the perspective of the American management. In doing so, Dole provides a useful chronicle of the company with little explanation or analysis of how the various changes he describes fit together or what they represent. In concluding, he reviews with pride America's role in bringing a 'vital' resource to the wider world and places the American management America's polar heroes: Kane, Wellman and Peary.

Elen Singh produced a more academic work on the role of the American government and the Arctic Coal Company in international negotiations over the sovereignty of Spitsbergen. ${ }^{16}$ She shows how the Arctic Coal Company drove the US government's interests and helped shape policy by carefully managing information flows and by lobbying prominent politicians. Her work describes the complex interrelation of international governments surrounding Spitsbergen's future political status and how industrial concerns played into that dynamic. More recently, Seth DePasqual completed a master's thesis that sought to explain the evolution of the Arctic Coal Company's main mine, Mine 1, in terms of its relationship with technology, human and natural landscapes. ${ }^{17}$ Using evidence garnered through archaeological survey and documentary research, DePasqual considers the chain of operations at the mine to identify the various forces upon the system.

16 Singh, Elen C., The Spitsbergen (Svalbard) Question: United States Foreign Policy, 1907-1935 (Oslo: Universitetsforlaget 1976).

17 DePasqual, Seth, "Winning Coal at $78^{\circ}$ North: Mining, Contingency and the Chaíne Opératoire in Old Longyear City” (Social Sciences Department, Michigan Technological University, 2009). 
Other authors have written about the company in Norwegian and Swedish. The author made selective translation and examination to understand the subjects explored, the methods used and key conclusions made. Adolf Hoel, geologist and Polar historian, was one of the preeminent authorities on Spitsbergen history and his three volume account of the archipelago's human history is one of the most widely cited works of later researchers. ${ }^{18}$ Hoel's extensive personal experience with the archipelago bolstered his understanding of early-twentieth century changes and his knowledge on the Arctic Coal Company came from documentary sources as well as personal inspection of the works. In 1915, the Norwegian syndicate that bought out the Arctic Coal Company asked Hoel to assess the operations for them to assist with their negotiations. ${ }^{19}$ Hoel devotes significant space to the Arctic Coal Company, and like Dole, mostly details the series of events and changes of its history with little analysis of their broader meaning.

Thor Arlov has produced three works that involve the Arctic Coal Company. In 'Svalbards Historie 1596-1996' he overviews the entire human history of the archipelago including the coal rush. ${ }^{20}$ He details the major aspects of the Arctic Coal Company's history based on the foremost historical accounts available, including the central personalities, coal production levels, the technologies used and important aspects of Longyear City's makeup. In 'A Short History of Svalbard,' Arlov condenses the prior work into a much shorter English language account with no further detail on the Arctic Coal Company. ${ }^{21}$ Arlov's 'Store Norske 75 År.' (in English, Store Norske 75 years) provides a

18 Hoel, Adolf, Svalbard's Historie 1596 - 1965, 3 vols. (Oslo: Kildahls Boktrykkeri, 1966). 19 Hoel, Adolf, The Arctic Coal Company's Coal Fields on Spitzbergen, J. M. Longyear Research Library Archives, Spitsbergen Papers \#3.

20 Arlov, Thor B., Svalbards Historie 1596-1996 (Oslo: Tapir Akademisk Forlag, 1996), 256-264. 21 Arlov, Thor B., A Short History of Svalbard (Oslo: Norsk Polarinstitutt, 1989). 
detailed account of the evolution of the operations of the Store Norske Spitsbergen Kulkompani, the company that bought out the Arctic Coal Company made and continued its operations. ${ }^{22}$ The work includes a history of the Arctic Coal Company in greater detail than Arlov's above accounts, including details on the life of J. M. Longyear and the culture conflict between Americans and Scandinavians, interpreting the company as a leader in the coal rush that helped form the later industry. The account provides limited detail on the evolution of the physical components of the Arctic Coal Company, evident in the lack of dates or approximate dating used in some photographs and in a map of Longyear Valley. The work then looks at the evolution of the Store Norske Spitsbergen Kulkompani operations by Advent Bay largely through changes in the physical form of its technical system and settlement.

Other works include Ole Vatten's master's thesis which considers the labor history surrounding Longyear City through the Arctic Coal Company phase and early Store Norske Spitsbergen Kulkompani history. ${ }^{23}$ Similarly, Ivar Lund-Mathiesen looks at the Norwegian military intervention on Spitsbergen in 1917 from a labor history perspective,

22 Arlov, Thor B. (ed.) Store Norske 75 År. (Longyearbyen: Store Norske Spitsbergen Kulkompani A/S, 1991).

23 Vatten, Ole, Longyearbyen 1905-1935: Et Norsk Samfunns Oppbygging Og Utvikling (Ph.D. Dissertation, University of Trondheim, 1980). In English, the title means'Longyear City 19051935: A Norwegian Society Built-Up and Developed.' 
including reference to labor under the Arctic Coal Company. ${ }^{24}$ Bjørg Eyjen gives a social account of Longyear City after the sale of the Arctic Coal Company. ${ }^{25}$

Other works consider provide broader accounts of industry on Spitsbergen and the Polar regions. Dag Avango, now a member of the LASHIPA project, wrote his dissertation on the history of the Swedish coal mining project on Spitsbergen between 1910 and 1934 and the role of Swedish scientific research in starting it. ${ }^{26}$ The work touches on the history of several companies of other nations working around the archipelago and describes the association of the design of Arctic Coal Company's operations with the Svea Mine.

Terence Armstrong, George Rogers and Graham Rowley co-authored a detailed overview of human development and exploitation across the Arctic, including Spitsbergen. ${ }^{27}$ The work comprehensively identifies the range of exploitation activities across all Arctic areas within outline historical, political, economic, environmental and social contexts and proposes areas of future political conflict and co-operation. David Sugden's human geography of the Arctic and Antarctic unifies the regions under regional development

24 Lund-Mathiesen, Ivar. Grubesamfunnene På Spitsbergen 1905-1917- Syndikaliststreiken Og Militærintervensjonen Sommeren 1917 (Ph.D. Dissertation, University of Oslo, 1974). In English the title is 'The mining settlements/societies in Spitsbergen 1905-1917- the syndicalist strike and the military intervention in the summer of 1917.'

25 Evjen, Bjørg. Longyearbyen 1916-1975: Fra Arktisk Arbeidsplass Til Etablert Industrisamfunn? Oslo, Norway: Unipax, 2006). In English the title is 'Longyear City 1916-1975: From Arctic Workplace to Established Industrial Discoveries.'

26 Avango, Dag, Sveagruvan: Svensk Gruvhantering Mellan Industri, Diplomati Och Geovetenskap (Stockholm: Jernkontoret, 2005).

27 Armstrong, Terence, George Rogers and Graham Rowley, The Circumpolar North: A Political and Economic Geography of the Arctic and Sub-Arctic (London: Methuen \& Co. Ltd., 1978). 
models. ${ }^{28} \mathrm{He}$ describes natural and human aspects as systems operating on different scales in space and time and looks for ways that the systems relate. Sugden specifically references Longyearbyen, the Arctic Coal Company's main settlement, as an example of a resource frontier settlement under Friedman's core/periphery model. ${ }^{29}$

\section{Objectives of the Dissertation and Theoretical Background}

The aim of this dissertation is to explain the development of the early coal rush on Spitsbergen by focusing on the operations of its most important actor, the Arctic Coal Company. Because the company was the first of several to develop an operational coal mine on Spitsbergen, where others had tried and failed, understanding their approach to doing so is critical to explaining the successful establishment of mining in this region. John Law's network approach of the Actor Network Theory (ANT) framework is the argumentative lens because it allows the numerous social, technological and environmental forces surrounding the effort to be drawn into descriptions of industrial change. $3^{30}$ Thus, the central question of the work is: what network did the Arctic Coal Company build to exploit Spitsbergen's mineral resources and why did they build it that way? The question considers aspects of Spitsbergen's history remaining to be explored by centering discussion on the association of different factors associated with the enterprise, and the problems encountered and solutions adopted while building it,

28 Sugden, David, Arctic and Antarctic: A Modern Geographical Synthesis (Totowa, New Jersey: Barnes and Noble Books, 1982).

29 Friedmann, J., Regional Development Policy: A Case Study of Venezuela (Cambridge, Massachusetts: MIT Press, 1966).

30 Law, John, "Technology and Heterogeneous Engineering: The Case of Portuguese Expansion" in Bijker, Wiebe E., Thomas P Hughes, and T. J. Pinch, eds., The Social Construction of Technological Systems (Cambridge, Mass: MIT Press, 1987), 111-134 and Law, John and John Hassard. Actor Network Theory and After (Malden, MA: Blackwell, 1999). 
identified by tracing the physical evolution of the company's land claims, technical system and main settlement through time.

John Law is one of the major figures associated with broad theoretical movement known as Actor-Network Theory (ANT). ANT is an umbrella term for a collection of approaches that hold that objects and organizations are both individual entities and a network of related people, materials and environments. It is important to recognize that the name itself is misleading. ANT is today only a theory in the broadest sense and in some ways is more a method of examination. ${ }^{31}$ As a theory, ANT postulates how and why technologies and artifacts are designed and why some succeed and/or are widely adopted while others fail to do so. At its inception, its recognition of the variety of factors surrounding technology change aroused some debate but today this position has gained widespread acceptance and is uncontroversial.

Protagonists of ANT and the larger discipline of the Social Construction of Technology reject the notion that technological explanations alone are adequate to describe the process of technological design and change. Numerous studies support this position by showing the critical role of other non-technical forces on technological outcomes. Thomas Hughes' history of power systems in Chicago, London and Berlin is a classic example, where he shows very different systems emerging in each despite the similar technological origins of all three. ${ }^{2}$ To explain this divergence, he argues that both social and technical factors played into the development of these large technical systems. ANT differs from Hughes' approach by its ability to describe technologies and technological

31 Latour, Bruno, "On Recalling ANT" in Law, John and John Hassard, Actor Network Theory and After (Malden, MA: Blackwell, 1999), 19-20.

32 Hughes, Thomas, Networks of Power: Electrification in Western Society 1880-1930 (Baltimore: The Johns Hopkins University Press, 1983). 
systems of numerous scales and complexities and in its focus on a wider range of factors, known as 'actants' in this context, including the environment. In ANT, actants are all the elements functioning in a network, whether they are human or non-human.

In drawing in social influences on analysis of technological design, theorists moved away from deterministic views of outcomes towards one of social negotiation. If technological explanations alone were adequate, design superiority based on engineering and scientific principles would explain the rise of certain technologies and the results would be almost inevitable. Recognizing social forces draws attention to the negotiations and interactions between numerous groups designing and using technologies. In this sense, technologies are not successful because of design superiority but because they effectively coalesce the social and technical forces surrounding them. This perspective draws historic investigation away from the final forms of technology to the processes that shaped their development.

Bruno Latour shows that formation processes can be controversial and complex, molded and held together by large social networks, while the outcomes, like a black box, can appear uncontroversial and be accepted without question. ${ }^{33}$ In this study, I open the box that is the Arctic Coal Company's operations by tracing the evolution of three of its major components, the land claims, the technical system and the settlement, in order to show how the company continued to learn about the obstacles facing them and adapted their methods to overcome them. I use Law's framework because he offers a flexible approach to describing technical development processes while drawing in a feature that is critical to the history of the Arctic Coal Company: the environment.

33 Latour, Bruno, Science in Action: How to Follow Scientists and Engineers through Society (Cambridge, Massachusetts: Harvard University Press, 1987), 1-4 
It is not possible to make a definition of the term 'environment' that succinctly differentiates it from other elements of our reality, particularly the 'human.' Certainly, there is no need within ANT to locate the exact distinction between the technical, social and environmental since most actants will be a combination of them. For this reason, I adopt as the definition of environment in this work Richard White's broad conception of nature as being the 'unmade qualities' of the earth. For the Arctic Coal Company, these are all aspects of Spitsbergen and the surrounding region which they and others had not prepared or developed, include but not limited to climate and weather, biology, geology and geography. 34

In his 'network' approach, Law describes technologies as being a network of heterogeneous elements designed by network builders to resist dislocation in a hostile environment. ${ }^{35}$ To be clear, the components of this statement are broken down and described in pieces using his description of a Portuguese galley as a model. The galley, he says, is both an artifact and a network of individual elements, or actants. The galley's 'network' coordinated men, wind and wood to effectively carry out naval warfare on the Mediterranean in the early to mid-second millennium. Actants from the sailcloth to sailing skill, from the rope to the ship's design, all coordinated in some way to allow the galley to achieve that goal. Furthermore, the galley associated with the Mediterranean environment, itself an actant. It was sleek to move quickly through the water and also sat low, which was suitable for the relative sheltered waters and currents of the Mediterranean. No one actant necessarily has a larger or more central role than any other and each is considered with the same analytical language. The approach has the

34 White, Richard, The Organic Machine (New York: Hill and Wang, 1995). 35 Law, "Technology and Heterogeneous Engineering: The Case of Portuguese Expansion," 111134 . 
advantage of pushing research to consider all the factors contributing to the development and makeup of a technology, rather than carrying forward preconceived ideas on the importance of individuals or technological design.

The above is not to imply that the actants of a network, like cogs in a machine, work together in a tight fit, direct manner. In fact the relationship between them can be flawed or complex and is one area of potentially fruitful research. Some actants may associate closely while others have a loose, even a fractious relationship. Law shows this to be part of the 'hostile environment,' which pulls against a cohesive network. In this case, the term 'environment' refers to the broad context or situation networks exist in. Without constant monitoring and effort, the entropic nature of networks will always draw them towards dissolution no matter how functional they are. Furthermore, networks often exist in competition with other networks that also apply pressure for dislocation, just as businesses compete in the marketplace.

The notion of a hostile environment is particularly well suited to this study of the Arctic Coal Company. Smaller tasks, such as building a dock or repairing equipment, could take tremendous human effort in Arctic conditions. Employees achieved these activities because of perseverance, adaptation, increased pay and increased expense. In this case, Arctic conditions and activity of construction related in tension but were held together through effort. The whole Arctic Coal Company network took continual monitoring, struggle and money to keep together. General Manager Scott Turner complained about the incredible effort it took him to manage all the components necessary to continue operations each year. Since the operation was never financially self-supporting, Ayer and Longyear constantly needed to contribute their private funds to keep the Arctic Coal Company operating and developing. If Turner had stopped his hard work or Ayer and 
Longyear had stopped funding the operation, the Arctic Coal Company network would have quickly collapsed and the relationship of all the components would have ceased to function together. In the case of the Portuguese galley, Law shows how its network failed when it was used in an attempt to sail to the Indies. In that case, the ship sailed in the different sea and wind conditions of the Atlantic thus changing the relationship of some of that network's actants. Unable to hold together, the network failed. Put another way, the galley sank. In time, the Portuguese successfully designed another network, or ship, that functioned within the different environmental conditions and successfully sailed to the Indies.

Using the Arctic Coal Company's operations as the unit of analysis places the Arctic Coal Company's management and owners as its network builders, while still being actants in the network. It was these men who made the major decisions on how the company should move forward. They attempted to build an industrial network that would avoid dislocation in a hostile environment. They attempted to develop and integrate technological systems and new economic markets. They worked towards creating an agreeable political position. They constantly attempted to create a stable, reliable workforce. All the above and more came from the heads of the company. The actions of these men alone, however, fail to explain the evolution of the operations because many of their attempts failed or were reconsidered. One of the major themes of this dissertation is how the company continued to learn about the environmental, social, economic and political realities surrounding the enterprise and how management constantly reviewed, adjusted and adapted their approach in an attempt to reconcile them with varying degrees of progress and success. In this way, the environment, labor, politics and other factors are crucial in considering the evolution of the company's operations. 


\section{Chapters}

The dissertation divides into three main sections. It examines the evolution of the company through an examination of its physical components. It then compares these with other American examples across the world to place the history in a wider context and isolate common and unique aspects of this history. Finally, it links this analysis with the remains of the company on the landscape to develop arguments of heritage significance for the physical remains still extant there today.

Chapter 2 provides an overview of Spitsbergen and its history, to assess the extent the company fit within Spitsbergen's wider economic, social and environmental context. It explains the environmental conditions of Spitsbergen and its current political status before reviewing its human history from 1596, including periods of whaling and hunting, science, exploration and the industrialization of Scandinavia.

Chapters 3-5 address the most significant gap of historical analysis on the company by explaining the evolution of three main components of the company to describe the company's larger network building process: its land claims, its technical system and its settlement. To do so, the author has reconstructed a near complete view of physical development and change over all years of operations. The scarcity of maps showing the company's layout complicated the task. The company's land claims have good documentation but most maps relating to the other components only show the years 1912 and 1913. To fill in the gaps, the author relied on extensive archival documentation and historic photographs to re-imagine the operations year-by-year. The outcomes then provided the basis for analysis on what the design and evolution of the components say about the company. 
Chapter 3 traces the decisions that led to the establishment of the Arctic Coal Company and examines the company's initial work on the landscape to understand its original goals. It begins by considering the actions by the founders of the company from $1902-$ 1905 that led to the formation of the enterprise. Analysis of the initial physical layout of the company on the Spitsbergen landscape forms the basis for explaining the company's broad strategy.

Chapter 4 describes and explores the steady expansion of the technical system as three phases of development, illustrated by maps of each that show the layout of technical facilities around the company's wharfing and storage area. Analysis pays particular attention to adaptations made to the system and looks for reasons to explain them. It shows how actants such as labor, Norwegian markets and the Arctic environment impacted the design of the system and how the company increasingly nuanced its operations to better facilitate mining and selling coal.

In the same way, Chapter 5 describes and examines the Arctic Coal Company's main settlement, Longyear City. It describes the evolution of the town and illustrates a fairly complete picture of the internal layout of the buildings, the space afforded to workers and its implications in an operational hierarchy. Longyear City is then compared with contemporary American industrial housing practice, including housing philosophy, the housing types and space-per-worker ratios of the bituminous coal regions of Pennsylvania and West Virginia in 1920 and the pattern of development of the Kennecott Mill Town, Alaska, which began and evolved in an almost identical timeframe.

Chapter 6 compares the location of the enterprise and the pattern of the Arctic Coal Company in sourcing technologies with contemporary American mining companies 
working overseas. It looks at the contemporary spread of American mining enterprises outside the US to show the uniqueness of the Arctic Coal Company's location. It then examines the basic pattern of technology importation by American mining companies overseas, specifically looking at the national origin of goods, equipment, capital and management adopted.

Chapter 7 builds on the previous chapters to develop a heritage argument for the historic significance of the remains of the company extant today, to help guide future discussions over actions that might affect them. It fits the argument within the current environmental legislation in place and uses the Burra Charter, ${ }^{36}$ a heritage philosophy that guides significance assessment and preservation action, to form arguments on the historic significance of the remains. The argument considers the Arctic Coal Company's legacy on Spitsbergen aspects of William Cronon's environmental history for the Kennecott Mines. 37

36 ICOMOS Australia, The Burra Charter: The Australia ICOMOS charter for the conservation of places of cultural significance 1999 (Canberra, Australia: Australia ICOMOS, 1999).

37 Cronon, William, “Kennecott Journey: The Paths out of Town.” In Under an Open Sky: Rethinking America's Western Past, edited by William Cronon, George Miles and Jay Gitlin (New York: W. W. Norton \& Company, 1992). 


\section{CHAPTER 2}

\section{Spitsbergen's Environmental, Historical and Industrial Context}

\section{Introduction}

To explain the extent that the Arctic Coal Company built upon existing land use patterns, social networks and knowledge of the area, this chapter considers how it fit within Spitsbergen's social, environmental and historical contexts. A description of the Spitsbergen's environmental and current political character introduces the archipelago and the modern economic history of Scandinavia. The changing socio-economic character of the region and its demand for coal and then explained followed by overview histories of the resource exploitation, scientific investigation, exploration and politics of Spitsbergen show how people had used the archipelago prior to the arrival of the Arctic Coal Company. A history of Spitsbergen's coal fields show the extent that people had explored and exploited them, particularly the lands the company claimed, before it initiated operations.

\section{The Environment and Political Status of Spitsbergen}

Spitsbergen is an archipelago located directly north of Scandinavia in the high Arctic, between around $76^{\circ}$ and $81^{\circ}$ North latitude. Originally known as 'Spitsbergen,' spelled 'Spitzbergen' by some including the Americans that form the subject of this dissertation, it is known as Svalbard today. It has a land area of around $63,000 \mathrm{~km}^{2}$ consisting of three main islands and numerous smaller ones. By far the largest, most densely populated and historically significant island is one originally known as West Spitsbergen, and today referred to as Spitsbergen. To avoid confusion in this work, this dissertation will refer to 
the whole archipelago as Spitsbergen and its largest island as West Spitsbergen. The name 'Spitsbergen' is used in preference to 'Svalbard' because that is the name the historical sources consistently used.

Spitsbergen is a difficult and often dangerous environment for human habitation. The archipelago is without sunlight for four months over the winter, from late-October to mid-February, and in constant sunlight for around four months in the summer, midApril to mid-August. It is heavily mountainous and glaciers cover about $60 \%$ of its land mass. It is not surprising, then, that the Dutch word 'Spitsbergen' means 'sharp peaks' or 'mountains' in English. The soils of the entire archipelago are subject to continuous permafrost, where sub-soils and rock remain permanently frozen regardless of the season. ${ }^{38}$ The soils above the permafrost, within what is known as the active layer, freeze and thaw with the seasons, often presenting difficult construction problems. ${ }^{39}$ Soils in spring can structurally weaken as they thaw and freezing wet soils will shift as they expand and 'heave.' Shifting soils can quickly distort roads and building foundations. To avoid this problem, Spitsbergen settlements today generally lay utility lines above the soil surface. 'Frost Jacking' is another serious problem where ice forms around objects such as stones and new construction and slowly pushes them to the surface. Even today, construction in cold regions can be very complicated and expensive. On Spitsbergen, the active layer measures from around 20"-40" (50cm - 1m).40

38 Huggett, Richard John, Fundamentals of Geomorphology, second edition (Routledge, 2007), 278-279.

39 McFadden, Terry T. and F. Lawrence Bennett, Construction in Cold Regions: A Guide for Planners, Engineers, Contractors, and Managers, third edition (New York: John Wiley and Sons, 1991), 143-145.

40 Humlum, Ole, "Monitoring Surface Climate Around Longyearbyen, Svalbard,: UNIS, Department of Geology, CALM project page, 3 January 2006, 
The archipelago is under the sovereignty of Norway, subject to the Spitsbergen Treaty of 1920. Nine industrialized nations settled the treaty during the Versailles negotiations held at the close of WWI, after years of negotiations starting in 1907, and individually ratified it. Norway ratified it in 1925 . The treaty makes the archipelago a demilitarized zone, provides equal economic access to signatory nations for many activities and provides a basis for taxing them. Today, 39 nations are signatories and negotiations over interpreting and updating the treaty are ongoing. ${ }^{41}$

For many reasons, Spitsbergen's environment and history have a unique place in the world. It has the warmest environment at its latitude yet no native peoples appear to have inhabited it. In fact, Spitsbergen's human history is more recent than the European interactions with the New World, despite its close proximity to Europe. For Europeans, Spitsbergen proved the testing ground for many of their future Polar activities. Many early explorations of the Arctic based themselves on or around the archipelago. Spitsbergen provided the hunting grounds for what was arguably the birth of modern whaling in Europe. It was also the scene for some of the earliest Arctic mining attempts and certainly for the first high Arctic mining.

Much of the human history of Spitsbergen relates to a key environmental factor: water currents. The earth's major water bodies move as relatively predictable currents across the globe, circulating warm and cold waters along with them. In the Atlantic Ocean, the Gulf Stream is one of the most important driving forces of that region's climate and is ultimately responsible for bringing the warm waters of the American Gulf to Spitsbergen.

<http://www.unis.no/10 STUDIES/1020 Courses/Arctic Geology/ag 204 more info/Ole/M onitoringSurfaceClimate.htm > (July 14, 2009).

41 Governor of Svalbard, "The Svalbard Treaty," October 3, 2008, $<$ http://www.sysselmannen.no/hovedEnkel.aspx?m=45301> (December 19, 2008). 
Massive quantities of warm water move north along the United States' east coast before heading east across the Atlantic. A portion of this water, known as the North Atlantic Drift, continues to the west coast of Europe and then along the west and north coast of Norway. These waters keep Western Europe much warmer than the areas of similar latitude in Northern America and Asia. Part of those currents continues north, passing along the western coast of Spitsbergen. Prior to recent decades, these currents opened Spitsbergen's western waterways over the summer months and provided ice-free waters along the cost of Norway, both of which are critical to explaining the context to the Arctic Coal Company's development. In contrast, cold waters flow from the north along Spitsbergen's east coast, rendering it much colder and less accessible. Those cold currents do have an important impact on the west coast as they can bring great quantities of ice around the southern tip of West Spitsbergen Island and up the coast, blocking early summer access to the fjords there and creating heavy fog conditions. Recent climactic warming has left Spitsbergen's western waterways almost permanently open today. Figure 2.1 shows the flow of warm and cold waters around the Arctic Ocean. 


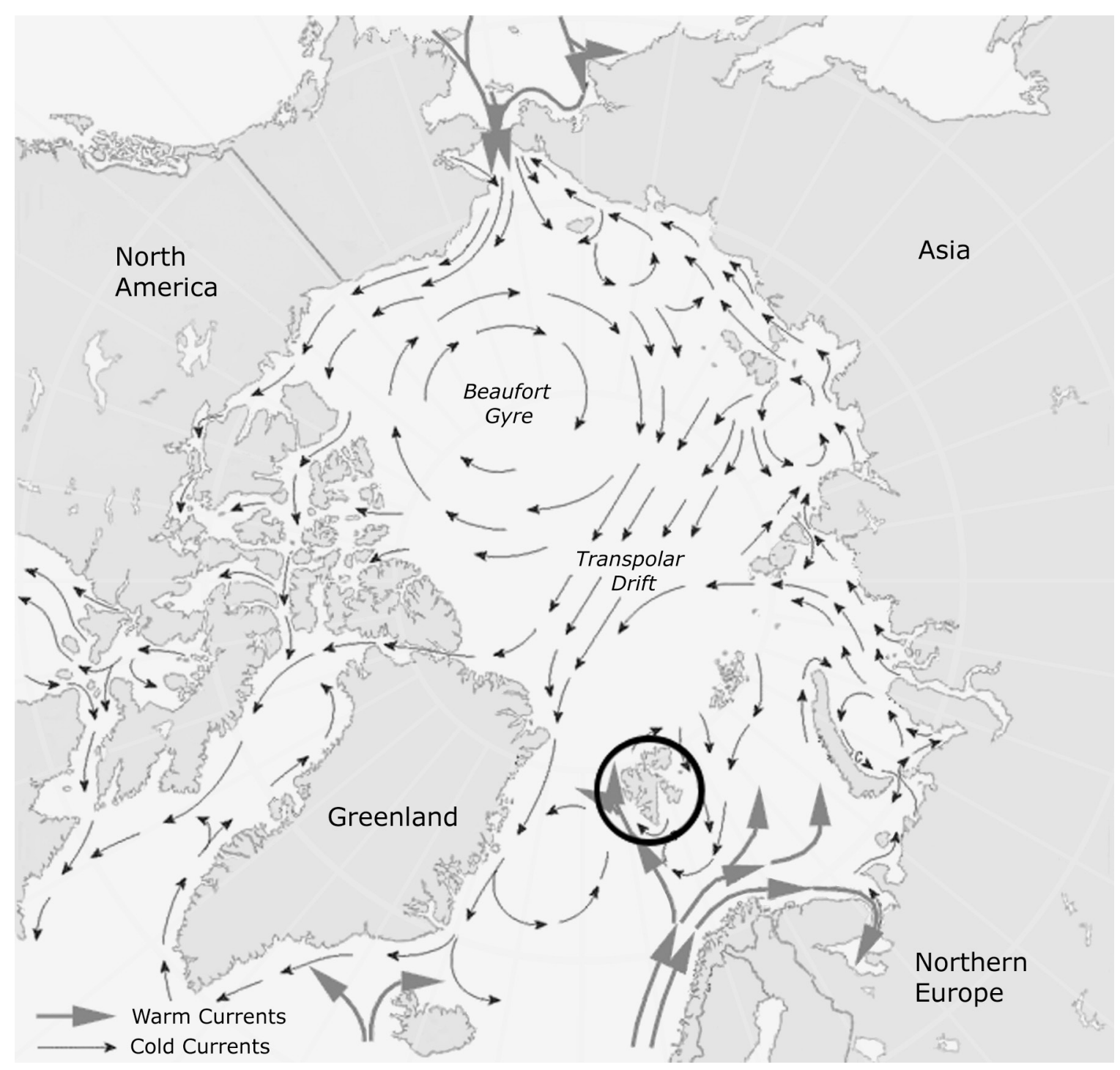

Figure 2.1 Map showing the flow of warm water currents (large arrows) and cold water currents (small arrows) around the Arctic. The size of the arrow is no indication of the force of the current. Spitsbergen is indicated by a circle. Note the warm waters passing along Spitsbergen's west coast while cold waters pass along its east coast. Map adapted by Cameron Hartnell, December 2008, from map by Philippe Rekacewicz and Emmanuelle Bournay (GRID-Arendal) in AMAP, AMAP Assessment Report: Arctic Pollution Issues (Arctic Monitoring and Assessment Programme: Oslo, Norway, 1998). Map found on AMAP Homepage, <http://amap.no/> (August 2, 2009). Used in line with AMAP reproduction policy, provided in Appendix B.

These water currents influence outside temperatures by warming or cooling the air passing over them. While less stable than water temperatures, the air temperatures of 
West Spitsbergen are generally much warmer than those of any area of similar latitude. The Arctic Coal Company measured the mean summer temperature at $39^{\circ} \mathrm{F}\left(3.9^{\circ} \mathrm{C}\right)$ and the mean for the winter at $-6^{\circ} \mathrm{F}\left(-21.1^{\circ} \mathrm{C}\right), 4^{42}$ which allowed permanent habitation of that area so long as outside food and support remain accessible. The Spitsbergen environment is too extreme for outdoor agriculture and settlements have always brought necessary food supplies from elsewhere or grown it in indoor facilities. With the exception of times of heavy weather, the Arctic Coal Company found the temperature acceptable for all year outdoor work and it never recorded any death or injury due to the climate. The coldest temperature ever recorded during the company's operations was over the winter of $1910-1911$ when it fell to $-56^{\circ} \mathrm{F}\left(-49^{\circ} \mathrm{C}\right) .43$ Little rain and snow falls on the archipelago over the year. The Arctic Coal Company estimated an annual combined fall of $61 / 2$ ", which places this part of the archipelago well within the rainfall bounds commonly defining a 'true desert.'44

An abundance of tree, plant and animal fossils speak of the areas once more southern location much warmer climate, 45 whereas today Spitsbergen lies beyond the tree line and Arctic tundra dominates the archipelago. Absent trees and plants of even moderate size, its landscapes lay wide open and geologic features remain exposed, often easily discernable to the casual observer. The flora consists mostly of small vascular plants

42 Atkinson, J.B. Spitsbergen Coal, 1913, 5, Riksarkivet, Spetsbergenarkivet, vol. 4, Stockholm, Sweden.

43 Article on Spitsbergen by Frank Dalburg, edited by Scott Turner, October 1960. 'Memorandum of certain changes at Spitsbergen (Svalbard) since 1915 (As Related to F. A. Dalburg).' Michigan Technological University Archives and Copper Country Historical Collections, Scott Turner Collection, box Z, folder Z29.

44 Encyclopedia Britannica, "Desert,” Encyclopedia Britannica Home Page, <http://www.britannica.com> (24 March 2009).

45 Dole, Nathan Haskell, America in Spitsbergen, i, 91-105. 
including numerous flowering species and a few dwarf tree species, as well as mosses, lichen and algae that grow slowly and are adapted to cold temperatures and low rainfall. Spitsbergen's trees do not produce anywhere near enough wood required for construction purposes, although water currents bring a great deal of timber to Spitsbergen's shores. The floral environment is generally very fragile and slow to recover from damage such as tracks left by vehicles or soil disruption. ${ }^{46}$

Faunal communities are a celebrated feature of tourism on Spitsbergen. An abundance of bird life including auks, terns, finches, geese and other species inhabit the archipelago's coast and waterways, with migration patterns as distant as the waters of the Antarctic. Beluga whales, seal, walrus and several fish species form the most notable animal species associated with the regions waters, many of whose numbers are recovering from historic overexploitation. The Greenland whale, or right whale, once seen in abundance is today a rare visitor. Few animal species live on Spitsbergen, including Arctic foxes, polar bears and reindeer. 47

\section{Economic History of the Region}

\section{Northern Scandinavian Industrialization}

Northern Sweden and much of Norway experienced a rapid industrialization towards the end of the nineteenth century that became an important economic context for exploiting the coal resources of Spitsbergen. By the early-twentieth century, Norway and Sweden had opened four large iron mining areas inside the Arctic Circle and constructed railways that linked two ranges with ports on the Norwegian Sea, the Baltic Sea and the southern

46 Governor of Svalbard, Svalbard: Experience Svalbard on Nature’s own terms, 9-13. 47 Ibid., 11-12. 
commercial centers. Concurrently, the northern regions also quickly expanded their populations by immigration from the south, bringing state institutions with them. For Sweden, these changes were the fulfillment of a long held desire to claim and transform its northern lands, often at the expense of the local Sami peoples. ${ }^{48}$ They were also part of Swedish efforts to stem dramatic population migrations out of Scandinavia occurring in the late-nineteenth and early-twentieth century. 49

Forest related industries led industrialization in the Swedish 'Norrland' during the midnineteenth century. Soon, mining concerns became interested in the region's mineral resources leading to the opening of four large iron regions in Sweden and Norway. The Swedish people had an extensive history of mining hard rock areas such as the large copper deposits at Falun and the iron deposits of Dannemora, both in south-central Sweden. While minor iron mining had started on Iluvaara Mountain, today Malmberget, in the early-eighteenth century, it was not until 1888 that a rail line reached the area to promote industrial development of the resource. English investors built the Gällivare Line to connect Malberget with Luleå on the Baltic Sea, which a nationalist Swedish government soon purchasing for a small sum to gain greater control of the north. ${ }^{0}$

From the 1880s, prospecting schemes pushed to claim and develop nearby iron deposits of Kiruna, long known by local Sami peoples and identified by Swedish scientists. Kiruna remained isolated from good transportation links, however, and the region did not

48 For more, see chapters by Sverker Sörlin and Pär Eliasson in Bravo, Michael and Sörlin (eds.), Narrating the Arctic - A Cultural History of Nordic Scientific Practices and Brunnström, Kiruna - A Swedish Mining City from the Turn of the Century.

49 Hatton, T.J. and J.G. Williamson, 1994, "What drove the mass migrations from Europe in the late Nineteenth century?” Population and Development Review 20, 533-559.

50 Brunnström, Kiruna - A Swedish Mining City from the Turn of the Century. 
develop until rail lines connected with it. In 1898, the Swedish Parliament voted to continue the rail line at Malberget west through Kiruna to the Norwegian border while the Norwegian government voted to connect that line through to the port of Narvik. This line, the Ofoten Line, was expensive and difficult to build and took until 1902 to complete. Known as 'the most northern railway in the world,' the line did more than open up a new mining region. It encouraged immigration of great numbers of Swedes from the south, supported agricultural and industrial development and established Narvik as an important port on the Norwegian coast. It also assisted the iron mines as ice blocked the Baltic port of Luleå for more than half the year while Narvik's port always remained open. The mines at Malberget, by then producing over one million tons of ore per year, continued expanding their operations and the company LuossavaaraKiirunavaara $\mathrm{AB}$ began developing Kiruna's mines into a large mining enterprise. ${ }^{11}$ Also in 1902, the Dunderland Iron Ore Company from England attempted to open an iron field at Storforshei in central Norway with mixed success. $5^{2}$ From 1906, Norwegian interests began to develop the iron region adjacent the Varangerfjord, near the town of Kirkenes.53 J. M. Longyear, founding partner and President of the Arctic Coal Company, considered investing in this iron field from 1902 but never did so, as described in chapter three. Figure 2.2 provides a map that shows these four iron regions and the rail lines that linked with them.

51 American Geographical Society, 1903. "The Most Northern Railroad," Bulletin of the American Geographical Society 35(1):49-50.

52 "The History of Rana Gruber AS," Rana Gruber AS Home Page, <http://www.ranagruber.no/index.php/13536?_wpsid=9oubeul1cgeo648dtojb1d22d4> (March 4, 2009).

53 Lloyd, Trevor, 1955, "Iron Ore Production at Kirkenes, Norway," Economic Geography 31(3):211-233. 


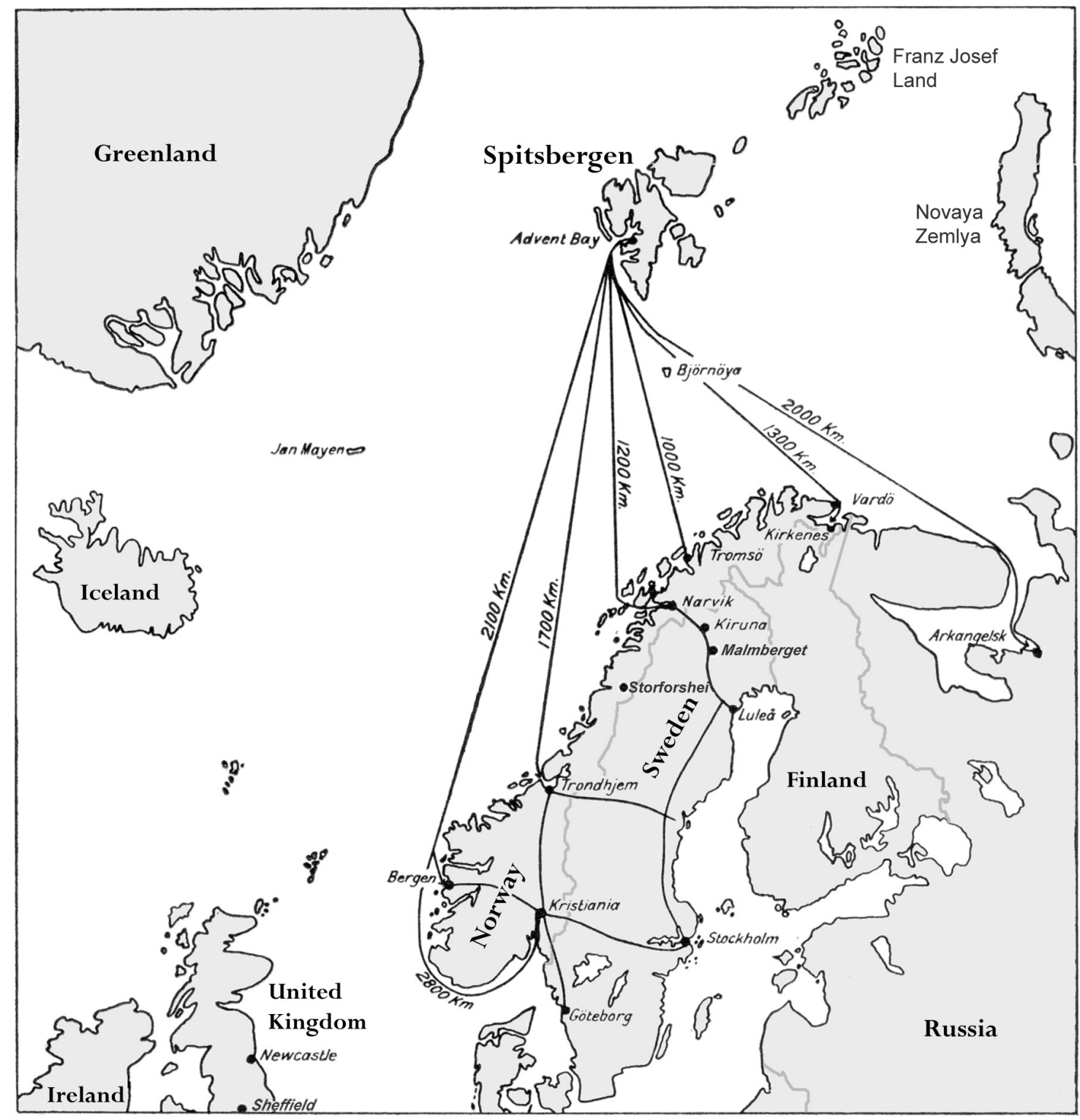

Figure 2.2 Location map showing Spitsbergen in relation to northern Europe. The map shows the distance of Advent Bay from ports associated with coal mining in Advent Bay. Note the railways of Norway and Sweden, existing in 1906, shown in black lines. Both Vardö and Kirkenes of north-east Norway are on the Varangerfjord, adjacent the iron lands J. M. Longyear considered investing in. Map adapted by author from Hoel, A., 'Spitsbergen-Bjornoykullene of Norges Braendselsforsyning. Saertryk av Teknisk Ukeblad nr. 51 1922. S. T. nr. 14,' Michigan Technological University Archives and Copper Country Historical Collections, Michigan Technological University, Keweenaw Digital Archives, MSo31-04-03-01. 
These northern developments existed within a broader period of industrialization for Sweden and Norway. Both small nations, they followed niche markets to compete with the industrial giants of Europe and America. Although politically united from 1814 to 1905, Sweden and Norway often pursued different industrial specialties. Historically, Sweden was more industrialized than Norway because of its larger population base and sophisticated iron industry. Competition with Britain in the second half of the eighteenth century left Swedish iron makers a minor figure in the European iron trade but a vigorous program of technology transfer of British iron technologies combined with local innovation led to the resurrection of the industry in the early nineteenth century. Beyond iron and sawmilling, however, Sweden remained a largely agricultural economy. By around the 1850s, Swedish engineering projects met with success and later innovations by Nobel and others later that century gained international recognition. 54

Mid-nineteenth century Norway was almost completely industrially undeveloped yet managed to become industrially sophisticated in several industries by the early twentieth century. Among other advances, from the 1880 s Norwegian companies were, for a time, the world's largest suppliers of wood pulp and within a decade were themselves producing paper, particularly for the then expanding newspaper market. By the turn of the century, Norway also had a modern grain milling sector. Norwegian companies designed and constructed increasingly sophisticated marine engines and came to control one of the world's largest marine fleets, part of which worked the world's oil trade. It also led the world in turbine and hydroelectric technology, supplying international customers and supporting domestic energy needs and industrial development. Norwegian companies began working on water turbine technology in the 1860 s and steadily 54 Bruland, Kristine (ed.), Technology Transfer and Scandinavian Industrialisation (NY: Berg, 1991). 
improved their methods. Their capabilities were proven when in 1902 Canadians commissioned a Norwegian firm to construct a massive hydro-electric system for the Canadian side of the Niagara Falls. 55

Both Sweden and Norway, rich with potential hydro power sources, invested in hydroelectric technologies to offset their use of coal for energy. Neither had significant domestic coal resources and were at the mercy of British and German suppliers for their needs, such as for steamships and the railways. By the turn of the twentieth century, Spitsbergen's coal resources represented a potentially attractive, politically independent energy source.

\section{The Human History of Spitsbergen}

\section{Hunting Activities}

Historians and archaeologists propose several possibilities for the discovery of Spitsbergen. Archaeological work of the 1890 s and 1955 found stone interpreted as stone age tools, suggesting the presence of native peoples on Spitsbergen, although the theory enjoys little support from the broader scientific community. ${ }^{66}$ Some historians have proposed that Norse seamen discovered Spitsbergen in 1194 A. D., as described by the Icelandic Sagas. ${ }^{57}$ The theory became prominent in the nineteenth century and played a significant role in Norway's claim to the archipelago during negotiations over its political control. Norway changed the archipelago's name to Svalbard on gaining sovereignty, in line with the name used in the Sagas. Other scholars, predominantly Russian, have

\section{Ibid.}

56 Arlov, Thor B., A Short History of Svalbard (Oslo: Norsk Polarinstitutt, 1989), 12.

57 Icelandic Annals, 1194. 
proposed that hunters from the White Sea Region, known as Pomoroy, discovered and visited Spitsbergen since the fifteenth or sixteenth century, backed by some documentary and archaeological evidence. $5^{8}$

The most commonly held view is that in 1596, the Dutch mariner Willem Barentsz and his crew became the first men to see the archipelago. He made the discovery during his third attempt to find a North-East passage to India, on behalf of the Netherlands. Barentsz named the lands 'Het Nieuwe Land,' and explored part of the coast before continuing his search. Barentsz died later that winter on Novaya Zemlya, now part of far northern Russia, but a map of the western coast and an account of the discovery was published soon afterwards and the name changed to Spitsbergen.59

While Barentsz' discovery extended Dutch geographical knowledge, it did little to extend commercial activities. Later expeditions that noted Spitsbergen's natural resources drew in a rush of interest, particularly from the English and Dutch. The Englishman Stephen Bennet landed on Bear Island, or Bjørnøya, a small island south of Spitsbergen also discovered by Barentsz on his third expedition, in 1604 and found great numbers of walrus there. In 1607, Henry Hudson visited Spitsbergen and found an extensive whale population, as well as birds, seal, polar bear, deer and walrus, with fresh water available in local streams. Another contemporary Englishman and whaler, Jonas Poole, visited

58 For an overview of the different theories on the discovery of Spitsbergen, see: Arlov, $A$ Short History of Svalbard. Vadim Starkov argues for Pomory discovery of Spitsbergen in the sixteenth century in Starkov, Vadim F., "Methods of Russian Heritage Site Dating on the Spitsbergen Archipelago," Acta borealia 22(1):63-78. Two arguments that challenge that perspective are: Hacquebord, L. "European Whalers and their Relations with Pomor fur Hunters on Spitsbergen." Paper presented at the Scientific Conference Barentsburg (Spitsbergen), Archaeological Researches in Spitsbergen and the International Polar Year, August 20-22, 2006, and Okhuizen, Edwin, "Dutch Pre-Barentsz Maps and the Pomor Thesis about the Discovery of Spitsbergen," Acta Borealia: A Nordic Journal of Circumpolar Societie 22(1): 21-41.

59 Arlov, A Short History of Svalbard, 9-12. 
Spitsbergen in 1610 and found coal and lead at Bear Island and coal at Kings Bay, or Kingsfjorden. ${ }^{60}$ The ecological descriptions coming from these expeditions foretold the commercial activities that arose over the next three centuries: first whaling, then hunting, and eventually mining coal and other mineral resources.

European interest in Spitsbergen's natural resources rose quickly. From 1604, the Muscovy Company from Britain began hunting walrus on Bear Island for their blubber, tusks and leather and began to hunt whales around Spitsbergen from $1911 .{ }^{61}$ By the next year Dutch, Spanish, French and Danish-Norwegian whaling groups competed for whale blubber. In the interest of mutual prosperity, the Muscovy Company and the Noordsche Compagnie, a Dutch company, partitioned Spitsbergen's west coast to allowing whaling from both nations to continue in relative peace. Danish whalers also continued as minor competitors in these waters. ${ }^{62}$ The Dutch, based in Smeerenburg on Amsterdam Island of north-west Spitsbergen, ${ }^{63}$ soon dominated the industry while the English found economic troubles but by the 1670 s Europeans largely abandoned the waters because of dwindling whale populations. Some groups found ways of continuing on by pursuing

6o Poole found coal on Bjørnøya in 1609 as described in: Purchas, Samuel, Hakluytus Posthumus or Purchas his Pilgrimes, vol. 14 (Glasgow: James MacLehose and Sons, 1906). Poole found coal at Kingsfjorden, then known as Deere-Sound by the English, in 1910, as described in: Purchas, Samuel.. Hakluytus Posthumus or Purchas his Pilgrimes, Contayning a History of the World in Sea Voyages and Lande Travells by Englishmen and Others, vol. 13 (Glasgow: James MacLehose and Sons, 1906).

61 Arlov, A Short History of Svalbard, 16.

62 Hacquebord, L., F. Steenhuisen and H. Waterbolk, "English and Dutch Whaling Trade and Whaling Stations in Spitsbergen (Svalbard) before 1660," International Journal of Maritime History 15(2003): 117-134.

63 Hacquebord, L. "Dutch Cultural Heritage in the Arctic" in Barr, S. and Chaplin , P. (eds), Cultural Heritage in the Arctic and Antarctic Regions. Monuments and Sites Series VIII (Oslo: International Polar Heritage Committee, 2004), 73-78 and Hacquebord, Louwrens, "Whaling Stations as Bridgeheads for Explorations of the Arctic Regions in the Sixteenth and Seventeenth Century," International Conference on Shipping, Factories and Colonization (Brussels, 24-26 November, 1994), 289-297. 
different species with different technologies but Spitsbergen never recovered as the site of a major whaling industry. ${ }^{64}$

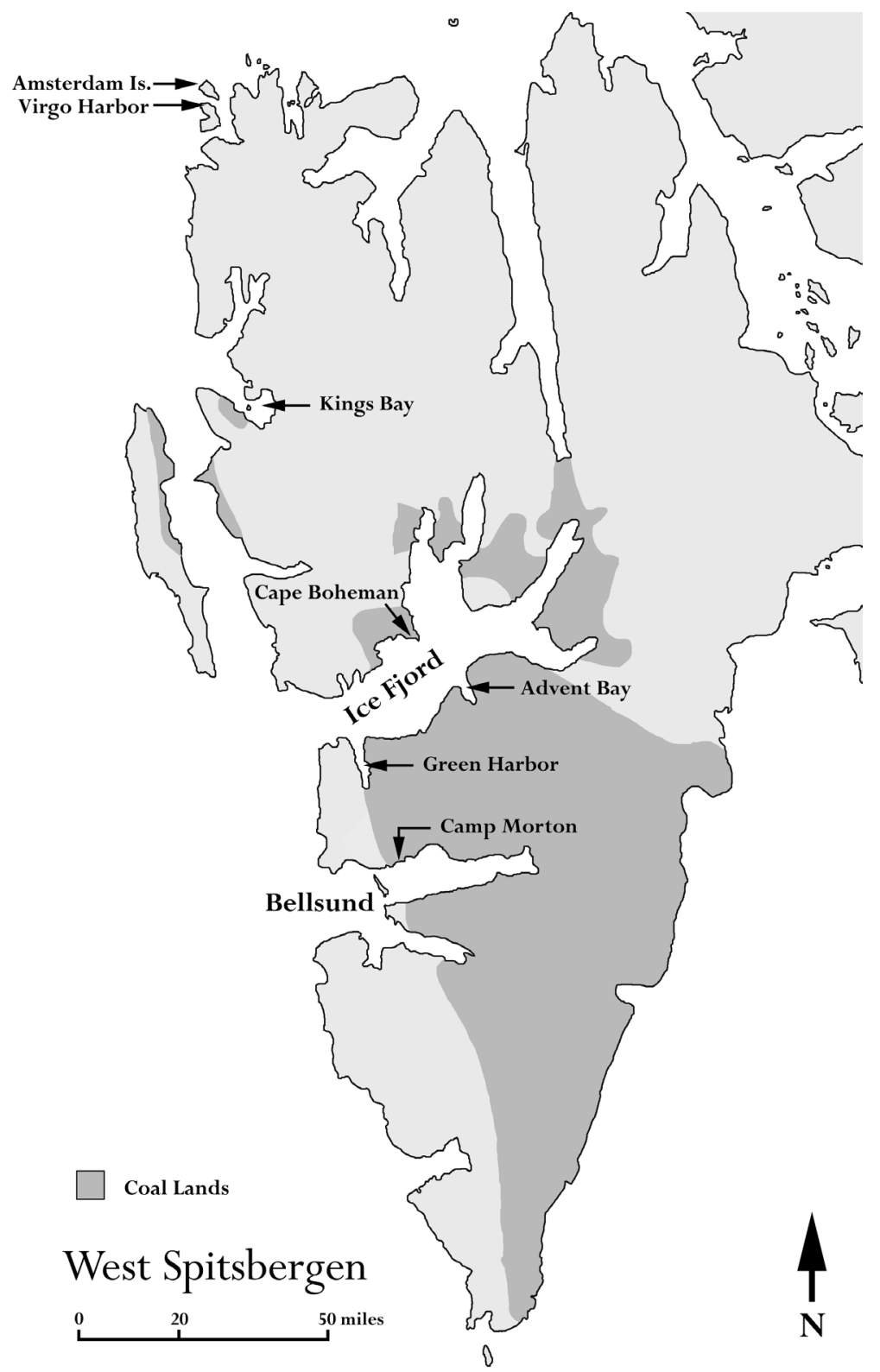

Figure 2.3 Map of West Spitsbergen Island showing the known location of coal lands in 1922 and the names of places mentioned in this chapter. Map by Cameron Hartnell, December 2008, based on map by Adolf Hoel, Michigan Technological University Archives and Copper Country Historical Collections, Michigan Technological University, Longyear Spitsbergen Collection (MSo31), box 4, folder 3 .

64 Ellis, Richard, Men and Whales (NY: Alfred A. Knopf, 1991), 223. 
Scholars disagree on the when Pomoroy hunters first came to Spitsbergen but whaling records show that they were present from at least the mid-seventeenth century. The Pomoroy, or Pomors, sailed annually to Spitsbergen out of the Russian port of Arkanglsk to hunt a variety of animals including walrus, seal, reindeer, fox and polar bear. They particularly sought furs for European markets but also hunted for food. ${ }^{65}$ Crucially, the hunters often stopped at Vardø, northern Norway, before heading north to the archipelago which may have inspired Norwegians to hunt on Spitsbergen themselves. The Pomoroy stopped hunting on Spitsbergen in the early nineteenth century. ${ }^{66}$

Norwegians began forming their own hunting parties for Spitsbergen in the 1770s, with assistance from Pomor hunting experts. Based out of Hammerfest, around 170 miles west of Vardø, Norwegian hunting parties initially had great difficulties and they only began to hunt successfully in the early-nineteenth century. Tromsø soon took over as the leading base of Arctic hunting and the number of ships leaving for Spitsbergen rapidly increased. As game numbers became scarcer from the mid-nineteenth century, the hunters sought more isolated areas, leading to the discovery of new lands and expanded geographical knowledge. ${ }^{67}$ This information became important for the future for scientific, tourist, exploratory and commercial operations that sought to access the archipelago. ${ }^{68}$ The Norwegian government supports the Norwegian hunting and

65 Jasinski, M.E., Pomors in Grumant: Archaeological Studies of Russian Hunting Stations in Svalbard, 2 Vols. (Tromso, Norway: Institute of Social Science, 1993). Ypie Aalders is currently investigating this question under the research framework of LASHIPA (LArge Scale HIstoric exploitation of Polar Areas): Aalders, Ypie, et al., LASHIPA 4: Archaeological Expedition on Svalbard, August 2 - 25, 2007 (Groningen: The Arctic Centre, 2008), 12-23.

66 Arlov, A Short History of Svalbard, 35-39.

67 Rabot, Charles, October/November 1919, "The Norwegians in Spitsbergen." Geographical Review 8(4/5): 213-216.

68 Arlov, A Short History of Svalbard, 40. 
trapping tradition today by issuing licenses for the activity. Low interest, however, suggests that the tradition may soon end.

\section{Scientific Expeditions}

Spitsbergen is today the focus of numerous major scientific investigations by teams from around the world continuing a tradition of scientific investigation that stretches back almost two and a half centuries. The Swede, A. R. Martin made what was probably the first strictly scientific investigation of the archipelago in 1758 when he followed a whaler north to make biological and meteorological observations. British and Russians soon followed with large, well outfitted expeditions, primarily concerned with discovering new sea passages to the eastern hemisphere but also investigating natural history and geographical questions. 69

B. M. Kielhau, a Norwegian scientist, initiated work on the archipelago's geology in 1827 and began a trend of more focused scientific work under smaller investigative parties. More intensive and systematic work began in 1858, particularly centered on geological questions, which for decades were dominated by Swedish backed teams who sent twenty expeditions there to $1909 .{ }^{70}$ Swedish scientists such as O. M. Torell, A. G. Nathorst and Gerard de Geer as well as the Fin A. E. Nordenskiöld, who represented Swedish science, substantially advanced geological knowledge on Spitsbergen, visible in increasingly detailed geological maps of the archipelago starting from $1865 .{ }^{11}$ Their efforts were backed by wealthy and influential benefactors who not only supported scientific progress

69 Vaughan, The Arctic: A History, 190.

70 Rabot, "The Norwegians in Spitsbergen," 213.

71 Harland, W. B., The Geology of Svalbard (London: The Geological Society, 1997) 16-18 and Dole, America in Spitsbergen, i, 175 - 184. 
but saw the potential to profit from Spitsbergen's mineral wealth and the chance for Sweden to gain political control. The work culminated in Nathorst's 1910 publication 72 that became the definitive account of the geology of the archipelago for many years. ${ }^{73}$

Towards the end of the century, Spitsbergen's geology gained more international interest under teams from Britain, Russia and elsewhere in Europe. Sir Martin Conway of England led work on the stratigraphy of central Spitsbergen, where prior investigations had largely focused on the coast. 74 Work by William Speirs Bruce, a Scot, and Adolf Hoel, a Norwegian, amongst others, show that scientific goals continued to mix with commercial and political ones. Bruce made numerous scientific expeditions to Spitsbergen from 1898 but also formed the Scottish Spitsbergen Syndicate (SSS) which claimed and prospected mineral lands in an attempt to profit from their sale. ${ }^{75}$ Similarly, Hoel made many investigations starting in 1907 while also claiming iron and coal lands. ${ }^{76}$

By the time John Longyear and Frederick Ayer looked into commercial possibilities on Spitsbergen in 1903, they had numerous printed works available to them that referenced the location and character of coal and other minerals there. Longyear took great interest in all works written about the archipelago, particularly those related to science but also

72 Nathorst, A.G., "Beiträge zur Geologie der Bären-Insel, Spitzbergens, und des König-Karl Landes," Bulletin of the Geological Institution of the University of Uppsala 10 (1910): 261-416.

73 Harland, The Geology of Svalbard, 16-18.

74 Ibid., 16-18.

75 Dag Avango, et al., LASHIPA 3: Third Field Campaign on Svalbard, August 7-24, 2006 (Groningen: The Arctic Centre, 2006), 11.

76 Dole, America on Spitsbergen, ii, 353 and 367. 
historic and exploratory accounts, and paid people to locate and translate them. 77 It is not clear which works Longyear referenced while planning to mine on Spitsbergen but archival collections of his documents hold numerous works of Spitsbergen that he owned written from the early-nineteenth century. 78

\section{Exploration}

The close proximity archipelago to Europe and its access to the Arctic Ocean drew numerous explorers attempting to reach the North Pole. From $1765-1818$, Russian and British expeditions that sought improved transportation routes to the east attempted to reach the pole by ship. The heavy ice pack blocked them all just north of Spitsbergen.79 Seeking to avoid the ice, North Pole expeditions turned to dirigible technology from latenineteenth century. The nationalist background to these activities is evident in the names chosen for the craft. Salomon August Andrée made two attempts 1896 and 1897 based on Virgo Harbor at Danes Island, in north-west Spitsbergen, in the Svea, or the 'Sweden,' later named the Örnen, or Eagle. On the second attempt the craft crashed on the ice and all three members of the team died and on White Island of north-east Spitsbergen. ${ }^{80}$ Walter Wellman, an American journalist representing the Chicago Record-Herald, made five attempts at the pole from 1894 - 1909, four near Andrée's

77 Regular correspondence between both John Longyear and Scott Turner, General Manager, and Dr. Alfred C. Lane on locating books and maps on Spitsbergen is contained in the Longyear Spitsbergen Collection (MS-031) and Scott Turner Collection (MS-018) of the Michigan Technological University Archives and Copper Country Historical Collections.

78 Longyear Spitsbergen Collection and Scott Turner Collection of the Michigan Technological University Archives and Copper Country Historical Collections.

79 Arlov, A Short History of Svalbard, 43-4 and Vaughan, The Arctic: A History, 115 and 142149.

8o Capelotti, P. J., By Airship to the North Pole: An Archaeology of Human Exploration (New Jersey: Rutgers University Press, 1999). 
camp and three in dirigibles named 'America.' Part of his efforts involved the construction of three telegraph stations to enable him to send news of his efforts to the newspaper, marking the first telegraphs sent from the high Arctic. All expeditions were poorly planned, resulting in quick failure. ${ }^{81}$

In 1925, the famed Norwegian Polar explorer Roald Amundsen and wealthy American industrialist Lincoln Ellsworth, attempted to fly over the North Pole using two fixed wing flying boats. Flying out of King's Bay, Spitsbergen, the attempt made it to within 136 miles of the pole before crash landing and barely making it back to the archipelago. In 1926, the pair drew on the expertise of the Italian airship pioneer Umberto Nobile for a dirigible attempt over the pole. The ship, named the Norge, or 'Norway,' left Kings Bay and successfully crossed over the Pole and reached Teller, Alaska, in 70 hours. Doubts over the validity of claims of previous expeditions to have reached the pole suggest that this expedition may have been the first to reach the Pole. ${ }^{82}$ Umberto Nobile subsequently led three successive flights over the Arctic Ocean from Kings Bay in 1928 in a dirigible named 'Italia.' His craft broke apart on the third flight culminating in an international rescue effort that eventually saved nine of the sixteen crew, including Nobile. That year, the Australian scientist Hubert Wilkins and his American pilot Carl Ben Eielson successfully completed the first fixed wing pan-Arctic flight between America (Point Barrow, Alaska) and Spitsbergen (Green Harbor) that sought to expand geographic knowledge of this region. ${ }^{83}$ The accessibility and geographic location of Spitsbergen led

\section{Ibid.}

82 Karpoff, Jonathan M. "Roald Amundsen," in Mark Nuttall (ed.), The Encyclopedia of the Arctic (Routledge, 2005). < http://faculty.washington.edu/karpoff/Research/Amundsen.pdf $>$ (9 December 2008).

83 Nasht, The Last Explorer: Hubert Wilkins, Hero of the Great Age of Polar Exploration. 
some contemporaries to suggest that it would be an ideal terminus for regular transArctic flights linking America and Europe. The idea never came to pass although today two companies schedule regular flights to the settlement of Longyearbyen in mediumsized commercial jet aircraft. ${ }^{84}$

\section{Political History of Spitsbergen}

Prior to the Spitsbergen Treaty agreement of 1920, major stakeholder nations considered Spitsbergen legally as terra nullius, meaning no government had jurisdiction over the land and no taxation existed over any economic activities. Under this status, citizens of all nations had the right to settle and exploit the archipelago so long as their activities did not imply or result in claiming control over it. To Swedish, Norwegian, English, Russian and other national governments, this status represented an opportunity to extend their own political strength and influence while finding potential economic benefits from resource exploitation. They used scientific research, mapping, economic activities, history and other actions as symbols to show active engagement and cultural connection with Spitsbergen to enhance their political case for control. This situation is by no means unique as world governments have used these techniques to claim Arctic and Antarctic lands for centuries and by the time of the Spitsbergen Treaty nations had claims on or legally controlled almost all Arctic lands. ${ }^{85}$

84 Tymms, T., 1925, "Aerial Navigation in the Arctic," The Geographical Journal 66(2):126-129.

85 Works that describe the political strategies to control the Arctic include: Wråkberg, Urban, "IPY Field Stations: Functions and Meanings," in: Legacies and Change in Polar Sciences: Historical, Legal and Political Reflections on the International Polar Year, eds. Jessica M. Shadian \& Monica Tennberg (Farnham: Ashgate Publishing, 2009), 47-71, Arlov, A Short History of Svalbard, Bravo and Sörlin (eds.), Narrating the Arctic and Berg, Roald. "A Norwegian Policy of the North before World War 1?," Acta borealia (1984)11-12: 5-18. 
The earliest political disputes over control of Spitsbergen arose soon after its discovery when European powers wrestled for access to whaling grounds. ${ }^{86}$ As major whaling activities ceased, however, the political division of the archipelago between England and the Netherlands was abandoned, although the historic events of that time formed part of later arguments over sovereignty. ${ }^{87}$ By the mid-nineteenth century, both Sweden and Norway, politically aligned until 1905, began working towards claiming Spitsbergen. The efforts continued a policy by these nations to strengthen their political control over their own Arctic lands through treaties, settlement and development. The Swedish state gradually extended its influence over the northern lands from the fourteenth century but truly cemented its control in the nineteenth century by using multiple strategies of scientific research, myth making, industrialization and institutionalization. Having found success at home, the government again adopted science as a tool to try to control Spitsbergen, visible in its extensive work there from $1858 .{ }^{88}$ Soon after, Norwegian actors began to exert their own influence. Norwegian scientists began to refer to the sea between Norway, Spitsbergen and Greenland as the Norwegian Ocean in the latenineteenth century, a name later advocated by Fridtjof Nansen, while some newspaper editors argued that Norway take control of the archipelago. The Norwegian government

86 Arlov, A Short History of Svalbard, 19-20.

87 Part of the British argument for their claim to Spitsbergen based on the early English activities there are expressed in, Freshfield, Douglas W., April 1918, "British Interests in Spitsbergen," The Geographical Journal 51(4): 245-249.

88 Sörlin, Sverker, "Rituals and Resources of Natural History: The North and the Arctic in Swedish Scientific Nationalism," in Bravo and Sörlin (eds.), Narrating the Arctic, 73-124 and Brunnström, Kiruna - A Swedish Mining City from the Turn of the Century, 2-5. 
even suggested bringing the question of Sovereignty to international attention in 1892 but political problems between it and Sweden prevented any resolution being reached. ${ }^{89}$

The commencement of large-scale coal mining operations on Spitsbergen by British and American interests brought urgency to the sovereignty question, not only because these companies could threaten the political claims of other nations but because they brought problems between different parties on the archipelago, where governments and the companies alike recognized the need for more legal regulation. Norway and Sweden restarted discussions in 1907 and soon other nations including Russia and the United States joined the negotiations. ${ }^{90}$ Since coal mining was then emerging as an important economic activity, involving the claiming of large areas of lands and the use of many workers, the Norwegian, Swedish, Russian and English governments started using mining efforts emanating from their nations as symbols of economic interest and influence to bolster their arguments. The Norwegian, Swedish and Russian governments were also very interested in access to new sources of coal for their national needs and variously used financial, political, logistic support and the supply of expertise to help their own mining groups survive and prosper. ${ }^{11}$ The Norwegian government also invested in a wireless telegraph system between Norway and Spitsbergen and started a postal service to establish a basic administrative connection with the region. ${ }^{92}$

Throughout its existence, the Arctic Coal Company regarded the political motivations of other nations as a severe threat to its own survival. It routinely competed against rivals,

89 Berg, “A Norwegian Policy of the North before World War 1?” 12-14.

90 Ibid., 14-16.

91 Dole, America in Spitsbergen, ii, 405 and 419.

92 Berg, "A Norwegian Policy of the North before World War 1?" 16-17. 
whose claims overlapped with the company's, and witnessed a great expansion of claims and competitive activities from 1908.93 The company responded by actively lobbying US government support, which had previously had very interest in the archipelago, and by undertaking some activities that symbolically enhanced its presence across its claims. The company successfully mobilized American government support for their claims and in negotiations over the archipelago. 94

On Spitsbergen, the Arctic Coal Company marked its lands with signs but also made some prospecting and mining efforts that would improve its operations and enhance the strength of their claims by expanding the area and the visual impact of their work. General Manager Scott Turner's decision to open a new mine, Mine 2, across the valley from Mine 1, is a good example of the multiple role of some activities as he saw opening the mine as an opportunity to better calculate the value of minerals there, enhance the value of the property upon its sale and to protect their claim to the area against rival claimants. 95

\section{Spitsbergen's Coal Fields before the Coal and Mineral Rush}

People knew of coal on Spitsbergen almost as soon as they knew of the archipelago itself. Since that time, visitors found coal in numerous areas and had opportunistically taken small amounts of it for their needs. For example, Sir James Lamont's account of the

93 The Arctic Coal Company closely documented the activities of rival land claimers, which they called 'trespassers,' in its annual reports, all available in Michigan Technological University Archives and Copper Country Historical Collections, Scott Turner Collection (MS-018).

94 Singh, The Spitsbergen (Svalbard) Question.

95 Letter from Scott Turner, General Manager of the Arctic Coal Company, to the Arctic Coal Company, June 21, 1912, Michigan Technical University Archives and Copper Country Historical Collections, Longyear Spitsbergen Collection (MS-031), box 5, folder 4. 
voyages he made around Spitsbergen from the 1850s-70s describes many of the coal areas then known to exist and their past use. ${ }^{96}$

Lamont, a wealthy English politician and adventurer, hunted and travelled throughout the northern European Arctic for his own pleasure. On Spitsbergen he found two coal areas at Kings Bay, one of which he noted had been 'exposed in the old whaling days, and since mined by the Swedes.'97 He himself took 120 bags for use on his steamer. Lamont found indications of coal at Black Point off Edge Island, or Edgeøya, a large island at the south-east of the archipelago. He pursued a report of coal just west of Coal Bay, east of Green Harbor in the Ice Fjord but did not find it. Finally, in 1871 Lamont directed his crew to open a small mine on southern Advent Bay that he named the Diana Coal Mine, after his ship, shown in figures 2.4 and 2.5. A little over three decades later, the Arctic Coal Company returned to this same area, looking to start a large-scale mining operation. Figure 2.3, above, shows the general location of coal on West Spitsbergen Island and the location of many of the places described here.

Lamont's account of the coal of the Diana Coal Mine would hardly have been encouraging to future prospectors. In it he states:

"The coal-bed was about three feet thick, and lay very horizontally between two layers of soft, mud-coloured limestone. It was harder to obtain than I anticipated, because saturated, through all the cracks and interstices, with water which had frozen into ice more difficult to break through than the coal itself, thereby rendering these fissures worse than useless in quarrying. This is tertiary coal, and is of fair quality, but contains a good deal of sulphur. When we began to burn it, so much water and ice was unavoidably mixed with it that the engineers had to let it first drain on deck in the hot sun and then mix it with an equal bulk of Scotch

96 Lamont, James, Yachting in the Arctic Seas or Nortes of Five Voyages of Sport and Discovery in the Neighborhood of Spitzbergen and Novaya Zemlya (London: Chatto and Windus, 1876).

97 Ibid., 293. 
coal. Consumed in this way the ten tons obtained in three days was a useful addition to the fast-dwindling stock on board." 98

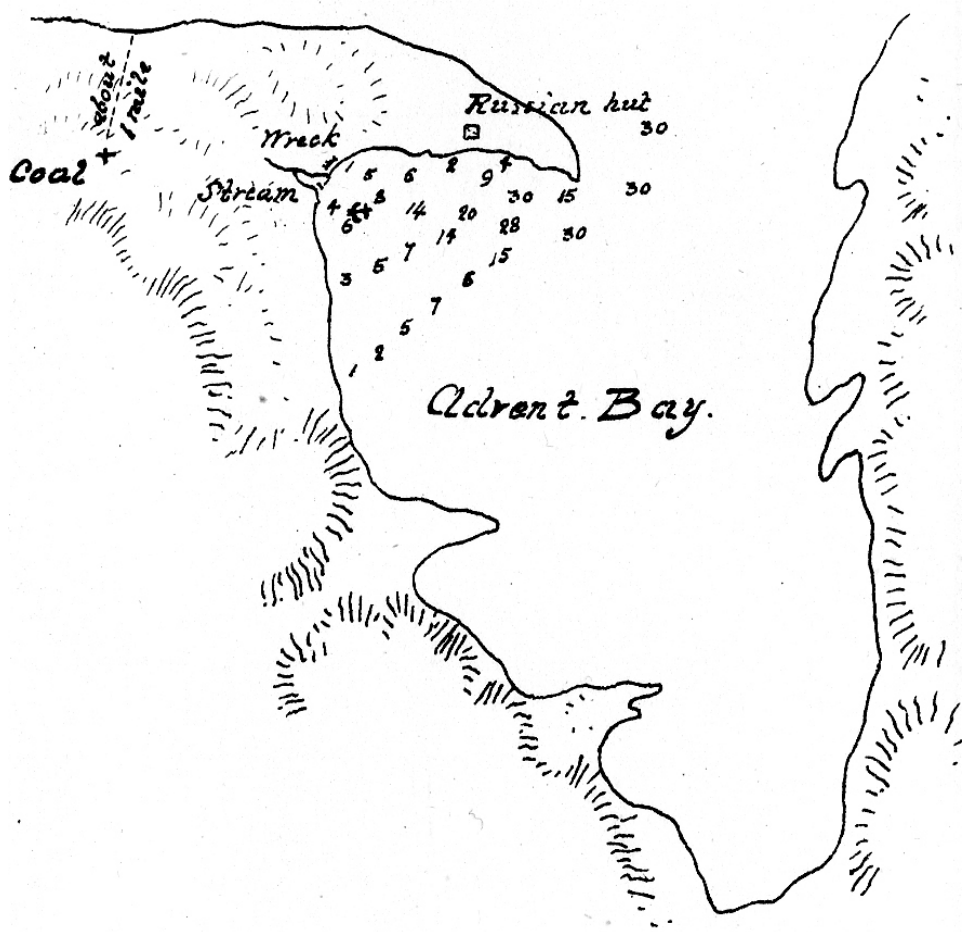

Figure 2.4 Plan of Advent Bay showing the location of Lamont's Diana Coal Mine. Lamont, Yachting in the Arctic Seas or Notes of Five Voyages of Sport and Discovery in the Neighborhood of Spitzbergen and Novaya Zemlya, appendix 1.

While groups such as Norwegian skippers, scientific expeditions and hunters had taken coal across different parts of Spitsbergen to support their activities ${ }^{99}$ and scientists had known of coal at Advent Bay since C. W. Blomstrand's geological work in 1861, ${ }^{100}$ Lamont appears to be the first to have exploited the coal there. In the last decade of the nineteenth century, a tourist industry that took visitors to Spitsbergen in the summer months gained popularity, culminating in a Norwegian company erecting a small, pre-

98 Ibid., 282-3.

99 Avango, Sveagruvan: Svensk Gruvhantering Mellan Industri, Diplomati Och Geovetenskap, 72-101.

100 Other geologists that found coal there include Richard Von Drasche in 1872, Dr. P Couteaud in 1893, and Sir Martin Conway in 1896. Dole, America in Spitsbergen, i, 172-185. 
fabricated hotel on Advent Point, on Advent Bay, in 1896, which may well have taken coal from the slopes above. That business quickly failed and the Arctic Coal Company eventually bought the structure to use as a store and warehouse. ${ }^{101}$

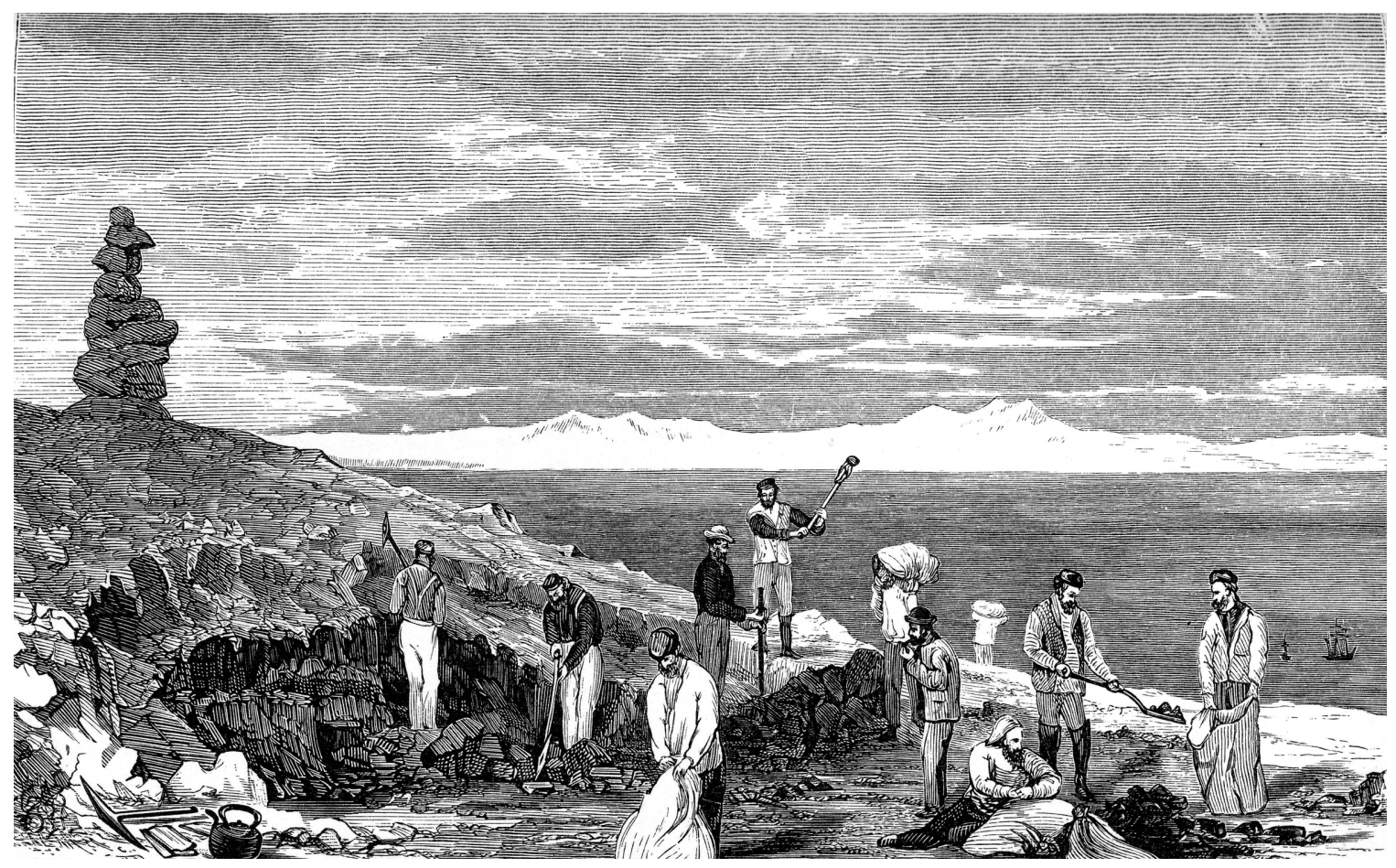

Figure 2.5 Drawing of men mining coal at Lamont's Diana Coal Mine. The depiction appears to be an artistic interpretation rather than a realistic depiction of the mine. Lamont, Yachting in the Arctic Seas or Notes of Five Voyages of Sport and Discovery in the Neighborhood of Spitzbergen and Novaya Zemlya, facing 283.

\section{Spitsbergen's Early Coal Rush}

By the close of the nineteenth century, many people had found, mined or heard about Spitsbergen's coal and disseminated the information to a broader audience. J. M. Longyear and his associates, some of the founders of the Arctic Coal Company, heard general and occasionally conflicting accounts of the coal from various sources while touring the archipelago and Norway. It took a growing market for coal in Scandinavia,

101 Dole, America in Spitsbergen, i, 155. 
high coal prices and the boldness of a few small Norwegian groups to cement this region as a potentially viable commercial mining region. These first efforts established some of the basic land divisions, knowledge and future plans that larger companies then pursued.

In 1899 Skipper Søren Zachariassen led a small Norwegian group in the first attempt at commercial coal mining on Spitsbergen. The group exploited a peninsula on the north side of the Ice Fjord called Cape Boheman, filling one sloop with coal and selling it in mainland Norway. With high coal prices, he found some success and formed the Kulgrubekompagniet Isefjord-Spitsbergen the next summer to claim the peninsula. ${ }^{102}$ The coal seam they chose to mine was easy to find as it was visible from the water just above the shoreline and along an adjacent beach. since the archipelago was then legally terra nullius, the company had no formal legal means to secure their claims. In response, the company installed numerous claim markers around the peninsula and built a hut near their mine, both serving as visual reminders to others of their presence. The company also claimed and mined the east side of Green Harbor during these two years. After that time, the company ceased mining coal but continued to maintain their right to their claims.

The early success of Zachariassen encouraged other small Norwegian companies to claim coal lands. In 1900, the company A/S Bergen-Spitsbergen claimed a large area of land on the north side of Advent Bay. In around 1904, the Spitsbergen Coal \& Trading Company, a British group, took over this claim and began to develop the first all year mining operation with a settlement known as Advent City. Another Norwegian group, the

102 Ibid, 186-7. 
Bergenske Kulkompagnie, began mining in Van Mijenfjorden at what later became known as Camp Morton in 1900 but only continued to $1901 .^{103}$

Also in 1900, another three men went to Spitsbergen and claimed a large area of land on the southern side of Advent Bay, including the former Diana Coal Mine, under the banner 'The Trondhjem-Spitsbergen Kulkompagni.' The group also claimed the Cape Boheman lands, although never seriously worked the area. The backgrounds of the men made them well represented for a coal mining operation there. Captain Henrik Naess, then about 37, had over twenty years experience in Arctic hunting and sailing and knew the northern Norway and Spitsbergen regions well. ${ }^{104}$ Alfred Getz was an engineer and superintendent of Norway's Røros Copper Mines. Jacob Gronvøld was a director of Norway's Ofoten railway. Kulgrubekompagniet Isefjord - Spitsbergen, under Zachariassen, had hoped to claim the same Advent Bay lands that year but arrived too late, finding their rivals had already installed claim signs and stone cairns at various prominent points and built a simple fence made with posts and rope. ${ }^{105}$ The claim stood at an estimated $178.5 \mathrm{~km}^{2}$ of land, shown in figure 2.6 , which the company registered with the Norwegian government. ${ }^{106}$

103 Hoel, Svalbard's Historie 1596 - 1965, 1440.

104 Dole, America in Spitsbergen, i, 260.

105 Ibid., i, 187.

106 Brochure titled "Vaste Deposits of Coals on the Spitzberg Island Secured for Drontheim Account," Michigan Technological University Archives and Copper Country Historical Collections, Longyear Collection (MS-031), box 1, folder 9. 


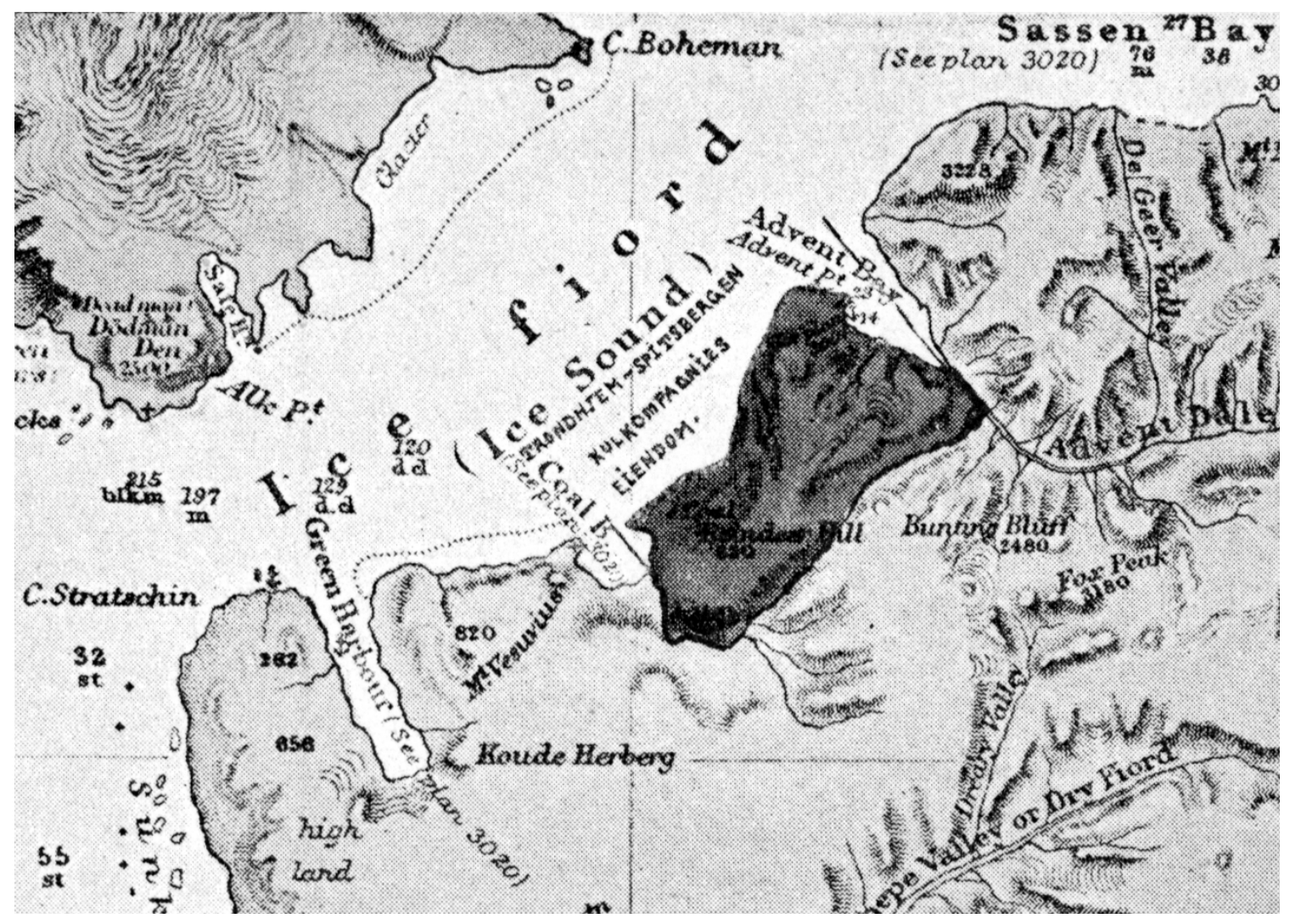

Figure 2.6 A section of 1903 Trondhjem-Spitsbergen Kulkompagni map showing their 1900 claim to lands, later overtaken and extended by the Arctic Coal Company. Brochure titled "Vaste Deposits of Coals on the Spitzberg Island Secured for Drontheim Account," Michigan Technological University Archives and Copper Country Historical Collections, Michigan Technological University, Longyear Collection (MS-031), box 4, folder 3.

The Trondhjem-Spitsbergen Kulkompagni tested the land's coal resources with particular attention to the land adjacent Advent Bay, which they determined a good shipping harbor. Hoping to develop the lands themselves, the men produced a brochure in 1903 that solicited for Kr.350,000 investment (Norwegian Kronor.) The brochure contained a geological analysis by Alfred Getz that referenced a chemical analysis of the coal. Gronvøld provided a commercial analysis that projected the amount of investment necessary, how it would be spent, and anticipated profits. 


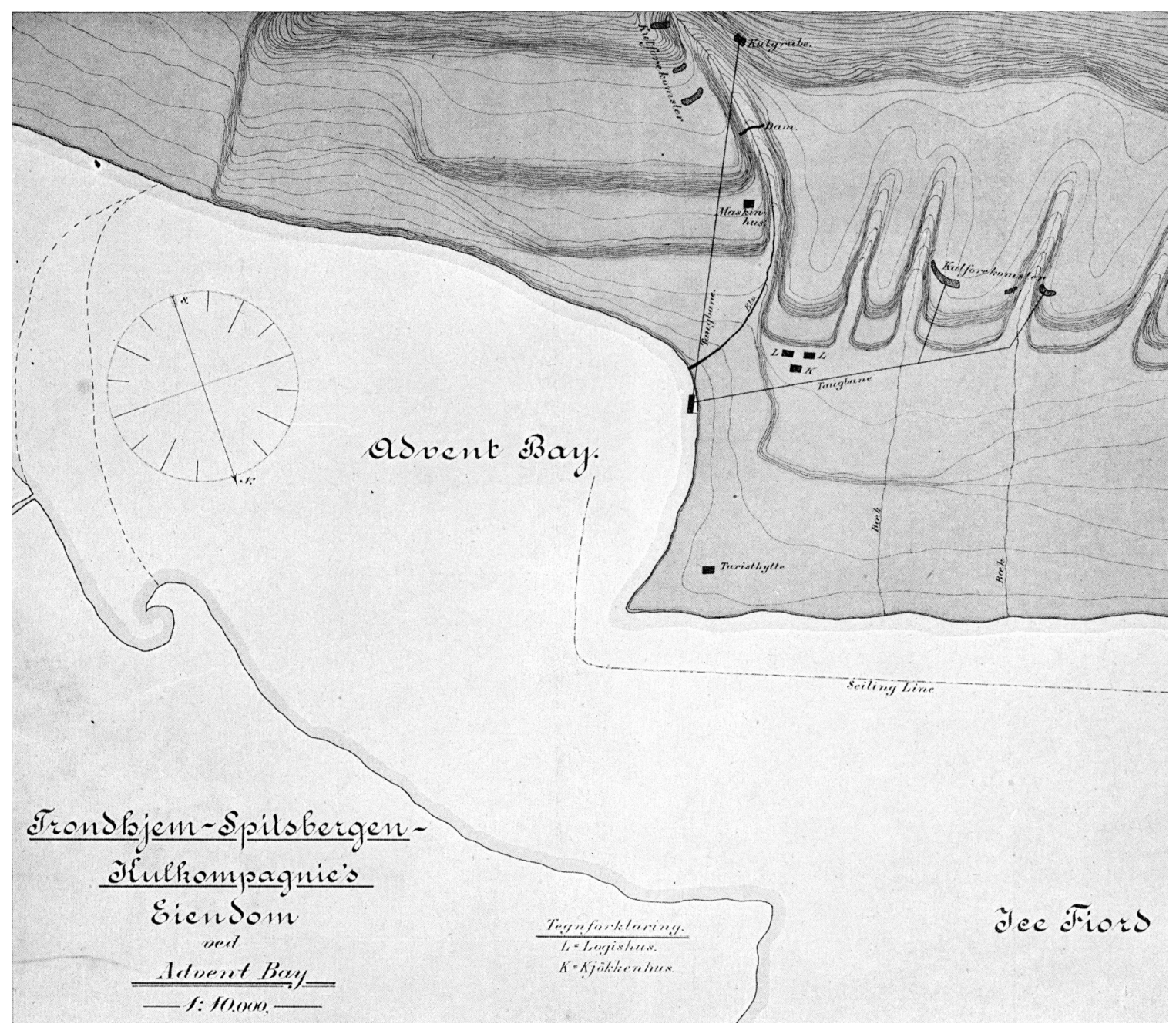

Figure 2.7 Part of Grönvold's proposed design for a coal mining operation on Advent Bay with three mines, each connected to an aerial tramway, with only two houses for men to run the operation. The buildings labeled ' $\mathrm{L}$ ' are lodgings, ' $\mathrm{K}$ ' is a kitchen, 'Maskinhus' is a machine house, 'kulgrube' is a coal mine and 'kulforekomster' is a coal seam. Brochure titled 'Vaste Deposits of Coals on the Spitzberg Island Secured for Drontheim Account,” Michigan Technological University Archives and Copper Country Historical Collections, Michigan Technological University, Longyear Spitsbergen Collection (MS-031), box 1, folder 9.

Both accounts were positive. Getz estimated that the lands held from 230 to 460 million tons of good quality gas coal. Both reports saw mining at this latitude possible and argued that little investment in machinery was necessary. Transportation costs would be low, they said, because a good harbor existed close to the mining area and a company 
could easily transport coal to ships via an aerial tramway. Grönvold went as far as to design a simple mining operation (see Figure 2.7) with three mines, each connected to aerial tramways, and one machine house all supported by a workforce of only 60 men. By his estimation, his plan would bring about an annual production of around 25,000 tons of coal that they would sell in Trondheim at an almost immediate annual profit of over $£ 5500$. These designs did not come close to the size and complexity of an operation needed to produce that amount of coal at this location, as seen in the subsequent development of the Arctic Coal Company operations, and may reflect the company's desire to attract investors rather than design a suitable technical system.

The brochure attracted Kr.60,00o investment and the company grew to sixteen owners, almost entirely from Trondheim, but this was not nearly enough capital to support the proposed enterprise. Their project stalled while looking for further funds. The company continued working the lands and in 1904, they mined 120 tons of coal, which they sold in Norway, and took orders of another thousand tons for $1905 \cdot{ }^{107}$ They also significantly extended the size of the claim with the addition of lands inland to the south-east. ${ }^{108}$ As the company struggled to find support in Trondheim, representatives of the American industrialist, John Monroe Longyear, read the same brochure and proposed interest in controlling the lands later that year. ${ }^{109}$

107 Letter from Olas Jeldness to J. M. Longyear, October 8, 1904. Statsarkivet i Tromsø, Arctic Coal Company Collection (nr. 101), box 91, folder '1903 - 1907 I-J.'

108 Letter from the Arctic Coal Company, and Frederick Ayer and John M. Longyear, to the Secretary of state, December 27, 1909, Michigan Technological University Archives and Copper Country Historical Collections, Longyear Collection (MS-031), box 1, folder 13.

109 Letter from W. D. Munroe to J. M. Longyear, March 28, 1903. Statsarkivet i Tromsø, Arctic Coal Company Collection (nr. 101), box 91, folder '1903 - 1907 M.' 


\section{Conclusions}

In many ways the Arctic Coal Company fit within and built upon the various contexts surrounding its establishment. It worked in the warmer western part of the archipelago that was well known and had been the focus of human activities there for centuries. The increasing industrialization of Norway and Sweden promoted greater settlement and introduced mining into ever northern regions, which expanded those countries' demand for coal and interest in obtaining their own supply. This provided the Arctic Coal Company with access to more workers, better and larger ports, and increased commercial demand in the regions closest to its operations.

The Arctic Coal Company had extensive information and skilled people available to it to help with its establishment and operation. Coal mining was the latest of a long history of resource exploitation on Spitsbergen that had supported the exploration of much of the archipelago. As such, visitors had access to men with extensive experience on Spitsbergen and its geography who could help them travel through the area. The company hired such a man, Henrik Naess, to captain their ship and provide local advice. ${ }^{110}$ By 1905, Scientists had made, and were continuing with, almost half a century of active geological study of the archipelago, which had described the location and quality of coal, including specific studies of the Advent Bay area and other lands that the company eventually claimed. At least two groups had already mined the slopes of southern Advent Bay by that time. One, Sir James Lamont, had produced a written account with descriptions mining there and the quality of the coal. The other, the Trondhjem-Spitsbergen Kulkompagni, who joined with the Arctic Coal Company, had

110 Dole, America in Spitsbergen, 260. 
four years experience in that location and had men with experience and influence in the Norwegian commercial realm.

The Arctic Coal Company's efforts largely sat outside the political situation and industrial development present at Spitsbergen, which placed pressure on the enterprise. The archipelago remained legally terra nullius, which allowed the company to claim extensive lands there but provided no legal means to protect the claims against rivals or provide a framework for settling disputes. The company also entered a political situation related to northern European competition over sovereignty of Spitsbergen which it had little knowledge of or control over. The American government, which eventually represented the company in these matters, also had almost no experience in or influence over the political discussions and it took some time until it could effectively assert itself on the company's behalf. By 1905, a number of groups had attempted mining coal on Spitsbergen but none had succeeded to develop an ongoing, industrial scale operation. In this sense, the Arctic Coal Company had no model on which to base its own development and needed to formulate its own approach to work in this environmentally difficult location. 


\section{CHAPTER 3}

\section{The Establishment of the Arctic Coal Company}

\section{Introduction}

John M. Longyear, Fredrick Ayer, and a group of sixteen Norwegian minor investors formed the Arctic Coal Company in 1906 but Longyear had considered investing in the Arctic European region for some years. The route to the decision to proceed was not direct and involved several attempts to bring together the elements necessary to develop a functional industrial enterprise. Once on Spitsbergen, the company interacted with the landscape in line with Ayer and Longyear's plans to profit from the area and faced numerous challenges while attempting to realize them.

The previous chapter showed that the Arctic Coal Company fit well within the environmental, historical and economic contexts surrounding Spitsbergen coal mining but Ayer and Longyear's particular motivations to invest there remain to be demonstrated. This chapter addresses the specific case by showing how and why the founding members of the Arctic Coal Company came to choose to invest in Spitsbergen mining and their strategy to profit from doing so. Analysis of Longyear's investigations of the commercial opportunities of the northern Norwegian and Spitsbergen regions using Law's network approach precedes an examination of the company's claiming, prospecting and mining efforts across the Ice Fjord to understand the Arctic Coal Company's initial landscape strategy and the extent that it changed up to the point of sale. 


\section{The Origins of the Arctic Coal Company}

Nathan Haskall Dole, historian of the Arctic Coal Company, makes much of Longyear's visit to Spitsbergen in 1901. Longyear's recognition of coal there, Dole suggests, was like "a seed ... which finds lodgment to sprout and grow into a mighty tree."111 In actuality, the visit provided little more than a personal familiarity with Spitsbergen. His journal notes the coal only once and then as a local curiosity rather than as a potential future commercial opportunity. ${ }^{112}$ Archival research into this period shows that this visit did not spur Longyear to look further into mining opportunities. Rather, prompting by his nephew and his nephew's Norwegian associate later drew Longyear's initial interest to opportunities for mining iron that existed in far northern Norway. On November 12, 1902, Longyear received a letter from his nephew, William Dearborn Munroe, that proposed he consider investing in the iron lands of the Varangerfjorden. In his reply, Longyear only discusses northern Norway and never mentions Spitsbergen. ${ }^{113}$

William Munroe attended the Michigan Mining School from 1893-95 to become a mining engineer, but never graduated. In 1897, he moved to Rossland, in British Columbia, Canada, to work at the recently established gold mining region. ${ }^{114}$ Munroe probably had no in-depth knowledge of coal mining because both the Michigan Mining School and Rossland are located in hard rock gold, copper and iron mining regions. Olaus Jeldness (1857 - 1935), a Norwegian mining engineer with experience in North

111 Dole, America in Spitsbergen, i, 196.

112 Journal of J. M. Longyear, J. M. Longyear Research Library, Longyear Collection, box 2, books 8 and 9 .

113 Letter from J. M. Longyear to W. D. Munroe, November 14, 1902. J. M. Longyear Research Library, Longyear Collection, box 2, letter copybook 2.

114 Michigan College of Mines, Graduates of the Michigan College of Mines up to an including the class of 1909 (Houghton, MI: June 1910). 
American and Norwegian mining, approached Munroe with information about undeveloped iron fields in the Varangerfjord of far north-eastern Norway adjacent Russia. On Figure 1.3 the Varangerfjord is visible adjacent Kirkenes.

Longyear took interest in Munroe's letter and asked for further details, saying "If these new iron ore fields in Norway is good or as half as large as your slight description seems to indicate I can 'swing' it easily." 115 Jeldness soon responded and described Varangerfjord's iron resources and environment in glowing terms, saying it had "the greatest iron veins in the known world today.” ${ }^{116}$

Citing the Norwegian government's geological report on the area, Jeldness described several veins of magnetic iron between 90 to 600 feet thick generally carrying between $60-70 \%$ iron and not known to contain less than $49 \%$. It was easily accessible in low ridges and above ground mounds. The iron had very little sulphur and phosphorus that could make smelting difficult and costly. Longyear would have recognized that Jeldness was describing a good shipping ore, one which would allow the extracted ore to be shipped directly to market without further processing, thus reducing operational costs considerably. Jeldness suggested power could come from hydroelectricity using three nearby waterfalls, or coal from nearby Andøya Island or even from Spitsbergen. The iron existed only a few hundred feet from a deep, ice-free harbor that would allow easy shipping to markets in England or the US. The Norwegian government, he wrote, is open to foreign investment. In short, Jeldness argued the iron lands "will make someone

115 Ibid.

116 Letter from Olaus Jeldness to W. D. Munroe, November 20, 1902. Statsarkivet i Tromsø, Arctic Coal Company Collection (Privatarkiv nr. 101), box 91, folder '1903 - 1907 I-J.' 
millions of dollars" with an investment of around $\$ 100,000 .{ }^{117}$ In a letter written on the same day, Munroe proposed that the three men attempt to form a syndicate of investors who would control three-quarters of a new company, leaving the men with the remainder. ${ }^{118}$

Jeldness and Munroe's letters touch on all major components of a hypothetical mining operation. Designed around the iron resource, it referenced power, shipping, markets, capital structure and politics. Spitsbergen's coal, originally ignored, is a background figure to this network, a secondary option for a coal source which itself is one of two available power sources. The network is simple and each of its elements are considered to a basic level only but complete enough to suggest to Longyear, Jeldness and Munroe that such a mining company could work.

Longyear was convinced to pursue the opportunity and acted quickly. He consulted an old friend and business partner, Frederick Ayer, and in January 1903 they drew up a contract for Munroe and Jeldness to visit Norway and the Varangerfjord with directions on researching and assessing the potential of mining its iron lands. The contract never mentioned visiting or investigating Spitsbergen's coal lands. ${ }^{119}$ Once they were in Norway, Longyear continued to draw on his extensive experience in managing iron lands to guide the two on how to pursue options and garner the necessary knowledge to make good decisions.

\section{Ibid.}

118 Letter from William Munroe to J. M. Longyear, November 20, 1902, Statsarkivet i Tromsø, Arctic Coal Company Collection (Privatarkiv nr. 101), box 91, folder '1903 - 1907 M.'

119 Contract between Frederick Ayer, John M. longyear, Olaus Jeldness and William Munroe, January 9, 1903. Statsarkivet i Tromsø, Arctic Coal Company Collection (Privatarkiv nr. 101), box 91, folder '1903 - 1907 M.' 
The two men arrived in Christiania, now called Oslo, by February and immediately found immense popular interest in the northern iron lands in the newspapers and from potential investors across Europe. They hastily sought out Jeldness' contact, Mr. Christian Anker, who had claimed a large section of the iron lands and was offering them for sale. Intensive discussions with him and his engineer as well as other contacts brought the men information that suggested the situation there was more complicated than initially anticipated. By the end of April they had revised the original hypothetical network but still stood confident in the potential investment. They saw leasing or purchasing Anker's lands as the best route to development, despite the stiff Kr.18,000,ooo (around \$4,800,00o) asking price.

The men uncovered information that showed the concentration of iron on Anker's claim was lower than Anker had originally indicated. The iron ore closest the shipping harbor had a 30-40\% concentration, necessitating processing before being sold. An area of $53 \%$ ore that could, perhaps, be shipped directly to market was further away and more difficult to reach. Some of the ore was high in titanic acid and others high in phosphorus, both substances that complicated processing of the ores. On the other hand, mining the ore could be started quickly and cheaply as Anker claimed to have 800,000,ooo tons in sight that could be quarried. The Longyear group discussed several options without coming to a definite conclusion but now recognized the need for a concentrating plant and associated raw materials: limestone and coke. The men found a ready supply of limestone near the iron lands that would probably suit the purpose. Coking coal posed some problems. Coking coal is a valuable derivative of bituminous coal that has been refined of impurities to have a low-ash and low sulfur content and has a chemical structure that gives it physical strength. These qualities make coking coal desirable for 
use in metallurgical processing such as concentrating or smelting iron ore where other coals would not be suitable.

Investigations into the coal on Andøya Island, on the Norwegian coast around 400 miles away, and on Spitsbergen initially ruled out either since reports indicated that they both only had steam coal, a type of coal unsuitable for iron ore concentration but useful in producing steam or heat. Soon afterwards Munroe read a brochure on Spitsbergen, perhaps from the Trondhjem-Spitsbergen Kulcompagni referred to in Chapter 2, detailing the presence of enormous quantities of coking coal there. ${ }^{120}$ Other people testified to the men their belief in the presence of coking coal. Based on this information, the men now drew in Spitsbergen as a primary supply to the hypothetical mining company under discussion. Longyear wrote Munroe to express his continued interest in the project and asked him to begin negotiations over the terms of an option on Anker's land claims that would allow personal inspection of them.

Longyear agreed to pay Kr.3,00o for a 6 month option to investigate the property with the right to a further 18 months for Kr.25,000 more. ${ }^{121}$ Munroe, Jeldness and later Longyear then went to northern Norway and personally investigated the iron lands, taking samples for analysis. Privately their efforts established that the properties had the potential to become profitable. They found some direct-shipping ore and an "unlimited" quantity of concentrating ores. They also investigated lands outside Anker's claims and found good ores there that could, perhaps, augment or replace Anker's claims. The men

120 Brochure titled "Vaste Deposits of Coals on the Spitzberg Island Secured for Drontheim Account," Michigan Technological University Archives and Copper Country Historical Collections, Longyear Collection (MS-031), box 1, folder 9.

121 Letter from J. M. Longyear to William Munroe, April 29, 1903, Statsarkivet i Tromsø, Arctic Coal Company Collection (Privatarkiv nr. 101), box 91, folder '1903 - 1907 L.' 
now considered different options for developing this resource, all of which involved at least some concentrating of ores. ${ }^{122}$

The best operational approach to take was not clear and required further research. They needed to match an extraction and concentration strategy with interest from investors and markets, and in this vein Longyear tested the interest from both. He wrote to two groups he had business relations with in the past: U.S. Steel, then the world's largest steel manufacturing company, and Henry W. Oliver, a major American figure in iron mining and manufacturing. He received little interest from either. ${ }^{123}$ Longyear later wrote to two British iron furnace companies that he saw as potential customers but they replied that the iron ore possessed too much potassium for their facilities. ${ }^{124}$

Beyond these commercial problems, Longyear found other roadblocks to his plans. Even after concerted efforts, he was never able to come to terms with Anker on proceeding to the next stage of commercial involvement. Anker consistently asked Kr.25,00o for an 18 month option on the lands, as per the original agreement and maintained his very high asking price to purchase the lands. Longyear vigorously argued that the option terms were unfair. He stated that Anker had misled him by overstating the quality of the ore body and the level of control he had over them. Rather than having title to the iron lands,

122 Letter from William Munroe to J. M. Longyear, November 6, 1903. Statsarkivet i Tromsø, Arctic Coal Company Collection (Privatarkiv nr. 101), box 91, folder '1903-1907 M.'

123 Letter from J. M. Longyear to H. W. Oliver, October 7, 1903, Statsarkivet i Tromsø, Arctic Coal Company Collection (Privatarkiv nr. 101), box 91, folder '1903 - 1907 L.' and H. W. Oliver to J. M. Longyear, October 9, 1903, Statsarkivet i Tromsø, Arctic Coal Company Collection (Privatarkiv nr. 101), box 91, folder '1903 - 1907 N-O.'

124 Longyear wrote to both Messrs. C. E. Muller \& Co., Middlesbrough, England and Keene, Gust \& Nettlefolds, Cardiff, South Wales, on January 4, 1904. Statsarkivet i Tromsø, Arctic Coal Company Collection (Privatarkiv nr. 101), box 91, folder '1903 - 1907 L.' He described their negative response in a letter to Christian Anker, February 6, 1904, Statsarkivet i Tromsø, Arctic Coal Company Collection (Privatarkiv nr. 101), box 91, folder '1903 - 1907 L.' 
Anker held claims which would require negotiations with the Norwegian government on a variety of land use issues before he could declare full ownership. Longyear saw the government's involvement in the scheme as potentially hazardous as its position towards foreign capital was unclear and because it initially demanded terms on mining operations that were particularly severe. Longyear insisted Anker provide a six month extension to the original option free of charge or repay the costs of investigations already made, $\$ 12,000$, in exchange for all knowledge gained. ${ }^{125}$

Anker and Longyear failed to find common ground between their positions and interest from both sides eventually waned. Longyear never declared that his interest in mining the region was over and may have waited to see if better opportunities arose. ${ }^{126}$ Longyear always maintained that the Varangerfjord iron district had the potential to become a large and profitable iron district but was unable to bring together the necessary commercial, environmental, political and technical actants needed in the mining network. Longyear's conviction of the quality of the iron region was an important backdrop to him pursuing mining efforts on Spitsbergen, as any processing operation at Varangerfjord would require a large supply of coking coal, which he still believed to exist on the Spitsbergen archipelago.

These efforts represent the second attempt to form a hypothetical industrial network around Norwegian iron mining. In this case, the need to concentrate the ores made the network much more complicated as it necessitated securing supplies of raw materials

125 Letter from J. M. Longyear to Christian Anker, October 7, 1903, Statsarkivet i Tromsø, Arctic Coal Company Collection (Privatarkiv nr. 101), box 91, folder '1903 - 1907 L.'

126 One source suggests that Longyear and Scott Turner inspected the iron lands again in 1911. Yost, Edna, Scott Turner: Distinguished Alumnus Award 1966 (Houghton, Michigan: Michigan Technological University Alumni Association, 1966), 8. 
and designing a sophisticated technical system that could concentrate ores profitably. It also posed problems for potential investors, who faced increased cost and complexity, and customers, who saw the ore as more difficult to work with. While Longyear, Munroe and Jeldness developed the vague outlines of a network, they were unable to pull together the necessary components to make it happen. This second network was an evolution of the first that now directly drew in Spitsbergen coal, further discussed below. Spitsbergen got drawn into Longyear's discussion because of its potential relationship to an iron mining operation rather than its own separate value as a mining range. Spitsbergen was also drawn in because of a misconception of Spitsbergen's mineral resources; Spitsbergen has produced little coking coal during its history and the area under consideration by Longyear had none.

In contrast to the frustrating and increasingly complex situation Longyear found in Northern Norway, Spitsbergen's coal fields appeared to be an opportunity of great ease and profit. Longyear, Munroe and Jeldness briefly visited the Trondhjem-Spitsbergen Kulkompagni's claim on Advent Bay in the summer of 1903 to consider its potential within a larger Norwegian iron mining enterprise. There the men investigated the basic environmental features of the landscape; the quality of the harbor, the coal resources and the layout of the land. Longyear was immediately impressed:

"I may say that I never saw a more promising field for prospecting, as where satisfactory results seem more certain than I saw on Spitzbergen. It looks, to me, to be easy to do a fine, large business there with small outlay of money compared with probable results." 127

From their perspective, all major development aspects of the coal fields seemed to be simply and advantageously addressed. They investigated Advent Bay's environmental

127 Letter from J. M. Longyear to Fredrick Ayer, July 20, 1903. Statsarkivet i Tromsø, Arctic Coal Company Collection (Privatarkiv nr. 101), box 91, folder '1903 - 1907 L.' 
qualities on a basic level. The lands appeared able to facilitate an efficient mining operation that he could build quickly at low cost. Noting that hunters live on Spitsbergen all year, Longyear believed mine workers could do the same, allowing for continuous operations. Similar to the layout suggested in the Trondhjem-Spitsbergen Kulcompagni's investment solicitation brochure (see figure 2.7), he imagined a coal mine facing Advent Bay that connected to a dock off Advent Point by an aerial tramway. Advent Point offered an excellent shipping harbor that he thought would be open five months over the summer season. The perceived need for low investment removed the necessity for outside capital as Ayer and Longyear thought they could fund this operation themselves.

The group investigated the legal position of the American, Norwegian and Russian governments on claiming and owning Spitsbergen lands, which confirmed that Spitsbergen was terra nullius and had no government controlling it and no laws regulating it. The Russian position held that Spitsbergen's lands were "approachable by all countries whose subjects may seek to draw benefits from its natural resources" with rights to establish settlements as long as they do not preclude claiming the whole archipelago. ${ }^{128}$ From Longyear's perspective, he could establish a mining company without government interference and without taxation. Furthermore, he recognized his ability to claim large areas of land there at virtually no cost.

Longyear saw an almost unlimited potential demand for Spitsbergen coal in Norway. He and his associates still thought Spitsbergen could supply good coking coal, which could be used in refining Scandinavia's expanding iron ore sector. In the summer of 1904, Jeldness noted even greater interest in Varangerfjord by foreign capital and also

128 Translated letter from J. Schöning and S. Scheel, the Royal Department for Foreign Affairs, to Georg Fasting, engineer, May 11, 1904, Statsarkivet i Tromsø, Arctic Coal Company Collection (Privatarkiv nr. 101), box 91, folder '1903 - 1907 I-J.' 
translated a Norwegian newspaper article for Longyear which argued that coke furnace operations would be both advantageous and economically feasible for the iron ores moving through the Norwegian port of Narvik. Jeldness, admittedly subject to exaggerated points of view, pushed this perspective to Longyear: "We would certainly hold the key to Anker's iron properties, and probably also to all the iron industry in northern Norway." 129

Longyear also saw an enormous market for Spitsbergen's steam coals. Beyond general Norwegian consumption, Munroe noted an extensive market amongst Norway's large steamship companies and its growing railway network. ${ }^{130}$ Fortuitously, some of the leading men of those organizations were also stockholders of the Trondhjem-Spitsbergen Kulkompagni, including the superintendent of the Roros Copper Mines, director of Norway's Ofoten railway and $1^{\text {st }}$ Manager for the Nordenfjelska Steamship Company, which had twenty large steamships. ${ }^{131}$ Should it prove to be commercial quality, the market potential for Spitsbergen coal, coking or steaming, was theoretically enormous. The scale of demand diminished any issue surrounding Longyear's false assumption of the presence of coking coal, which prospecting and mining efforts soon proved. The company would simply sell to the steam coal market.

Finally, they noted that the Trondhjem-Spitsbergen Kulkompagni had no other interested parties discussing the purchase of the lands and would be malleable to the

129 Letter from Olaus Jeldness to J. M. Longyear, February 19, 1904. Statsarkivet i Tromsø, Arctic Coal Company Collection (Privatarkiv nr. 101), box 91, folder '1903 - 1907 I-J.'

130 Letter from W. D. Munroe to Frederick Ayer, March 7, 1905. Statsarkivet i Tromsø, Arctic Coal Company Collection (Privatarkiv nr. 101), box 91, folder '1903-1907 M'.

131 Letter from Fr. Bohne, shareholder in the Trondhjem-Spitsbergen Kulkompagni, to Olaus Jeldness, January 21, 1904. Statsarkivet i Tromsø, Arctic Coal Company Collection (Privatarkiv nr. 101), box 91, folder '1903 - 1907 I-J.' 
demands of Longyear. That group had originally attempted to establish their own operation with Kr.350,000 capital (around \$94,500) but only managed to have Kr.60,000 subscribed. ${ }^{132}$ The company owners wanted to continue their involvement in a new enterprise and initially asked for Kr.100,000 (around \$27,000) and a Kr.100 consideration fee. This broke down into a Kr.10,ooo cash option to investigate and work the lands during 1904, Kr.40,000 cash and Kr.50,000 in stock of a Kr.350,000 company formed to work the lands. ${ }^{133}$ Negotiations led to the option being altered with the Kr.40,000 cash requirement being dropped, Kr.8,000 added for the purchase of a tourist hotel on Advent Point, and the option being extended through 1905. Ayer and Longyear took up the option and sent Munroe to manage initial work on the tract in 1905. Satisfied with the results, they committed to the option's terms and organized the Arctic Coal Company (ACC) in West Virginia in 1906. The new company had $\$ 100,000$ capitalization, consisting of $\$ 5,500$ cash and 94,500 $\$ 1$ shares: 13,500 shares for members of the Trondhjem-Spitsbergen Kulkompagnie and the remainder divided between Ayer and Longyear, who invested equally. ${ }^{134}$ Ayer and Longyear had gained access to this parcel of land for an original capital outlay of only Kr.18,ooo (around \$4860). The company hired William Munroe to lead the company as its General Manager.

From the Actor Network Theory perspective, Longyear found the third hypothetical network attractive because it appeared to simply and effectively bring together all the

132 Letter from J. M. Longyear to Frederick Ayer, August 8, 1903. Statsarkivet i Troms $\varnothing$, Arctic Coal Company Collection (Privatarkiv nr. 101), box 91, folder '1903-1907 L.'

133 Letter from Fr. Bohne to Olaus Jeldness, November 16, 1903. Statsarkivet i Tromsø, Arctic Coal Company Collection (Privatarkiv nr. 101), box 91, folder '1903 - 1907 M.'

134 Letter from Olaus Jeldness to J. M. Longyear, February 16, 1904, Statsarkivet i Tromsø, Arctic Coal Company Collection (Privatarkiv nr. 101), box 91, folder '1903 - 1907 I-J.' 
actants required for a coal mining enterprise, including the various environmental features, Spitsbergen's legal status, the lands cost and the coal market. Longyear decided to proceed in Spitsbergen while still discussing investment in the iron lands. As Longyear's interest in the iron properties waned, he decided to pursue this third hypothetical network divorced of it.

\section{Ayer and Longyear's Landscape Strategy on Spitsbergen}

\section{Establishing the Arctic Coal Company's Land Claims}

In 1905, William Munroe led a team of 26 men to prospect the Trondhjem-Spitsbergen Kulcompagni claim under an option to do so before purchasing the claim. Munroe spent the majority of his time adjacent to Advent Bay, seeking to better understand the value of the area's coal resources and the viability of a mining operation there. He also went to other parts of the Ice Fjord and made three large land claims on behalf of 'Ayer \& Longyear,' bringing their holdings to more than 320,000 acres of land. ${ }^{135}$

Longyear and Munroe also wanted to negotiate on the land claim of the A/S BergenSpitsbergen on the north side of Advent Bay, between claims \#1 and $\# 3,{ }^{136}$ and planned to claim the coal lands to the north in King's Bay, ${ }^{137}$ seen on figure 2.3. Munroe also investigated supposed graphite lands around Safe Harbor, across the fjord from Green Harbor, with a view to possibly claim them but abandoned the idea on finding micaceous

135 Dole, America in Spitsbergen, i, 422.

136 Letter from Olaus Jeldness to William Munroe, December 4, 1903. Statsarkivet i Tromsø, Arctic Coal Company Collection (Privatarkiv nr. 101), box 91, folder '1903 - 1907 M.'

137 Letter from W. D. Munroe to Frederick Ayer and J. m. Longyear, April 8, 1905, Statsarkivet i Tromsø, Arctic Coal Company Collection (Privatarkiv nr. 101), box 91, folder '1903 - 1907 M.' 
schist and talc schist instead, which was not commercially valuable. ${ }^{138}$ Longyear later considered claiming guano deposits existing in the same area as a means to secure his claims on the archipelago. A 1858 law, the Guano Statute, provided American citizens the chance to claim unclaimed guano lands under the protection of the US government. In 1910, the US senate passed a bill to allow Longyear the right to the guano lands, which would include his existing land claims, but the US State Department recommended the government not pursue the bill and the idea was dropped. ${ }^{139}$ Should all their plans have all succeeded, Ayer and Longyear would have had a major stake in Spitsbergen's coal lands and dominated land ownership around the Ice Fjord.

The land claims had immediate practical value as they gave the Arctic Coal Company a great deal of developmental flexibility. Even though Munroe began the most extensive work on Advent Bay of Tract \#1, he still sought to prove its value before making large investments there and the other claims offered him alternative sites should he be disappointed. Companies commonly adopted this approach across the world as it expanded their commercial opportunities while reducing the risk of developing poor lands. Spitsbergen was no different. Ernest Mansfield and the Northern Exploration Company (NEC) claimed around 11,00o square kilometers of land ${ }^{140}$ and the Scottish Spitsbergen Syndicate (SSS) claimed huge areas across West Spitsbergen, both to explore and exploit a variety of minerals. ${ }^{141}$

138 Letter from William Munroe to Messrs. Ayer and Longyear, September 16, 1905, Statsarkivet i Troms $\varnothing$, Arctic Coal Company Collection (Privatarkiv nr. 101), box 91, folder '1903 - 1907 M.'

139 Dole, America in Spitsbergen, ii, 430-34.

140 Arlov, A Short History of Svalbard, 53-56.

141 Avango et al., LASHIPA 3: Third Field Campaign on Svalbard, August 7-24, 2006, 11. 


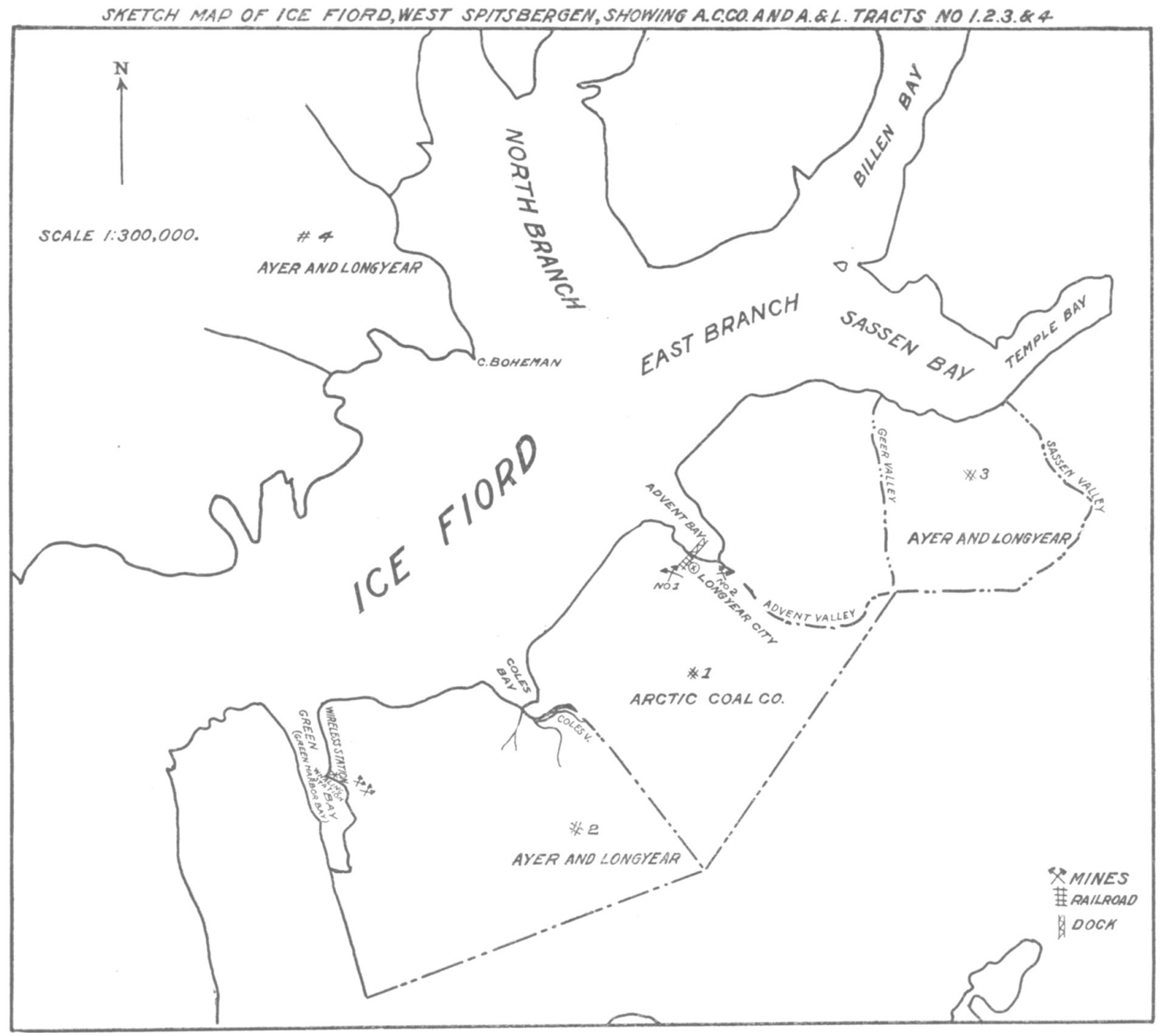

Figure 3.1 A 1913 Arctic Coal Company / Ayer and Longyear map showing their four land claims and mines around the Ice Fjord. Michigan Technological University Archives and Copper Country Historical Collections, Michigan Technological University, Keweenaw Digital Archives, MSo3102-12-01.

Munroe was quickly satisfied with the Advent Bay's coal and decided to pursue full mining operations there in early summer 1906. The Arctic Coal Company continued prospecting the remaining claimed lands, which were now less important to it from a operational standpoint but allowed Ayer and Longyear to pursue their long preferred approach to managing mineral lands: to profit from others leasing or buying their land in an expanding mining region. 


\section{J. M. Longyear's Pattern of Land Management}

Since 1870 , when he was twenty years old, Longyear had spent his working life managing the resources of Great Lakes region. ${ }^{142} \mathrm{He}$ first worked as an inspector and sorter of cut timber in Michigan's Lower Peninsula before accepting a contract from the state to survey some of its lands. From 1873 to 1878 , Longyear worked as a landlooker in Michigan's Upper Peninsula, surveying and evaluating timber and mineral lands for private and government clients. In 1877, the Lake Superior Ship Canal Railway \& Iron Company hired Longyear to investigate a suspected timber trespass on its lands.

Satisfied with his work and character, the company hired Longyear as their land agent to manage their over 400,000 acres of land in the Upper Peninsula. In this role Longyear developed a land management system that helped the company assess the lands they should keep and pay taxes on. This system developed to become the foundation to Longyear's approach to land management through the rest of his career. ${ }^{143}$

In 1879, Longyear hired a knowledgeable mineral surveyor to survey an area of lands bordering Wisconsin with specific interest in signs of iron ore. The survey successfully mapped the Gogebic iron range, known to exist as early as 1848 but still ill-defined and undeveloped by Longyear's survey. This was the third iron range found in Michigan's Upper Peninsula. The others included the Marquette Range, discovered in 1844, and the

142 The John M. Longyear Research Library in Marquette, Michigan, holds the best collection of documentary material related to the life of J. M. Longyear.

143 Longyear, John Munroe, compiled by Helen Longyear Paul, Landlooker in the Upper Peninsula of Michigan (Marquette, Michigan: John M. Longyear Research Library, 1960). 
Menominee Range, where iron deposits were first noted in 1850 (Figure 3.2 shows the location of these iron ranges). ${ }^{144}$

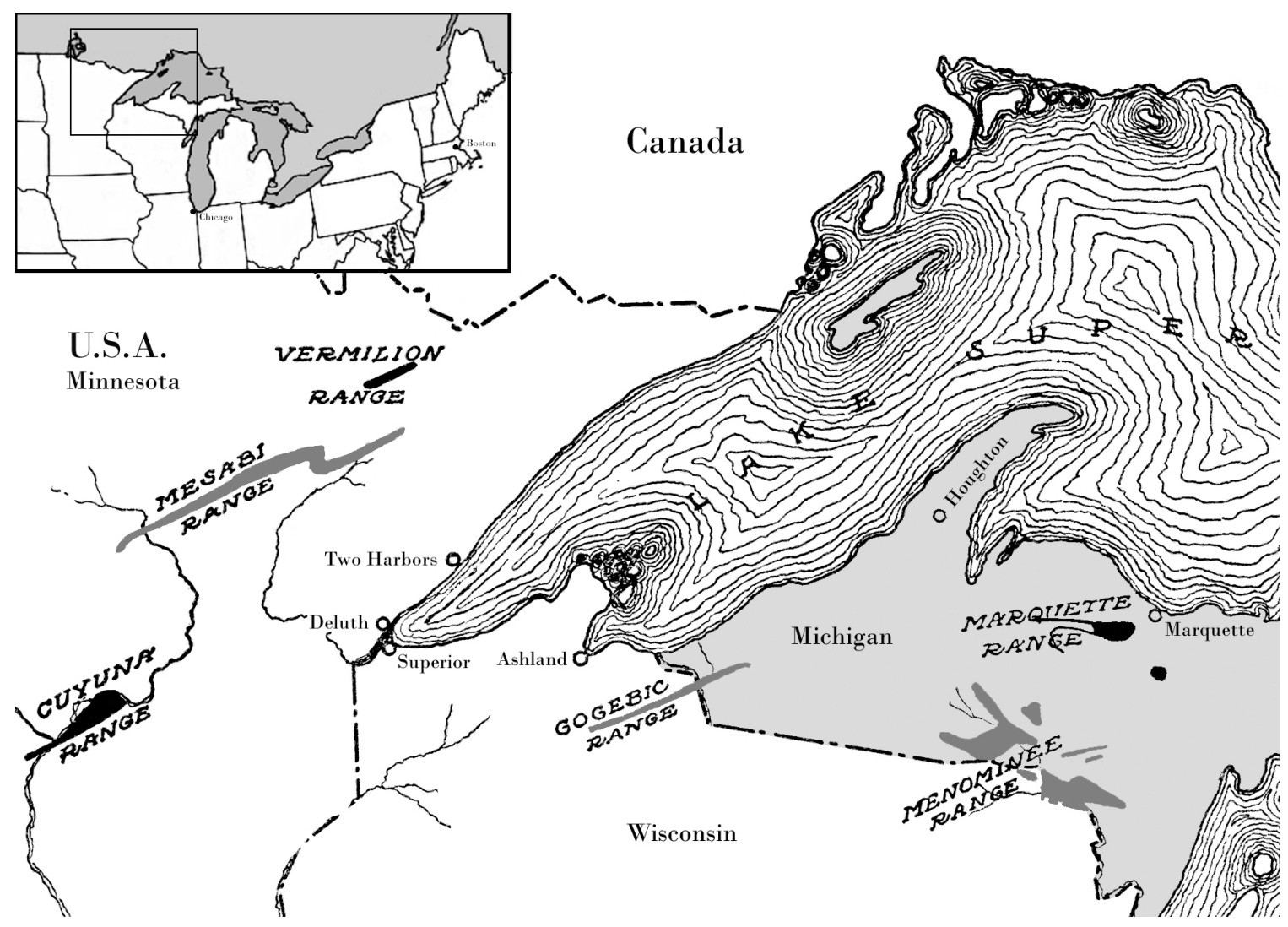

Figure 3.2 Map of the western Lake Superior region where Longyear spent the majority of his career. The shaded area shows the western portion of the Upper Peninsula Michigan, the area of Longyear's land surveys and main land holdings. Longyear held substantial interests in three iron ranges that are indicated here in lighter shading, the Menominee, Gogebic and Mesabi. Map by author adapted from map in Crowell \& Murray, Inc. The Iron Ores of Lake Superior (Cleveland: The Penton Press Co., 1920).

Longyear became closely acquainted with Frederick Ayer, the head of the Lake Superior Ship Canal Railway \& Iron Company's controlling family. The men soon forged a close business relationship that lasted through the rest of their lives. Based on his successes, Ayer made a deal with Longyear that he would give him half the acreage of any lands

144 Ibid., 68-69 and Eckrose, Roy, America's Gogebic Range: The Gogebic Iron Range of Upper Michigan and Northern Wisconsin (Saxon, Wisconsin: Exploration Press, 2007),13-14. 
Longyear bought for him, after recovering the purchase price, in exchange for his research and knowledge to choose the lands. Longyear used the opportunity to purchase significant amounts of land on the Gogebic and Menominee iron ranges, mostly in partnership with others.

Part of Longyear's successful approach involved the royalty lease concept that he apparently pioneered in the region. The concept involved leasing mineral lands to mining companies and receiving royalties for the ore removed. The approach allowed Longyear and those he represented to retain ownership over the land and profit from it while avoiding issues with the investment and management of a mining organization. Longyear first attempted this approach in 1880 on the Menominee Range for the soon renowned Chapin mine, then adopted it on the rest of his iron lands. He also sold the logging rights of nearby timberlands, whose wood was in demand by local towns and mining companies alike. His success in managing the lands enabled him to forge more business relationships with other land owners, further expanding his influence and personal holdings. ${ }^{145}$

Longyear achieved his greatest commercial success soon afterwards on a newly discovered iron range in Minnesota, known as the Mesabi Range. In 1885, geologists revealed that the iron from this region was equal in quality to that of the Gogebic. Longyear acted quickly and in 1887 he formed a syndicate that purchased 24,000 acres of land on the range. Another timberman, Russell Bennett, proposed that they approach the large land owning Pillsbury family for a joint venture to explore for iron on their lands. The man struck an agreement in 1890 that gave Bennett and Longyear half of the

145 Case, John and Shirley Schwaller, The Longyear Legacy: land, Timber, Minerals (Dallas: Horizon Communications, 1998), 10. 
more than 10,000 acres should a minimum of 10,000 tons of ore be found. Bennett and Longyear soon signed a similar agreement on 24,000 acres of Wright, Davis and Company lands. ${ }^{146}$

Longyear asked his cousin, E. J. Longyear, to survey the lands using a diamond drill. E. J. Longyear succeeded in finding massive quantities of ore, thereby giving the Longyear partnerships control over large amounts of high quality mineral lands. Longyear's partnerships on the Mesabi largely continued on the lease royalty approach and Longyear grew rich as the area quickly became America's largest iron ore mining region. ${ }^{147}$

Throughout his career around Lake Superior, Longyear preferred to concentrate on holding and managing lands rather than developing and operating mines. While his partners did operate a couple of mines in Minnesota, Longyear himself played a minor role in them and appears to have been involved personally in only one exploratory mine. ${ }^{148}$ In 1883 , he and a group of associates started an exploratory mining operation based out of Detroit called the Longyear Iron Mining Co. with \$50,00o capital and Longyear as General Manager. ${ }^{149}$ The company sold their holdings by 1886 . From that time forward, Longyear avoided investing in opening new areas, perhaps because he found so much success in managing lands while exposed to minimal financial risk.

146 See Case and Schwaller, The Longyear Legacy: land, Timber, Minerals and Torreano, Peter F., Mesabi Miracle: The 10o-Year History of the Pillsbury-Bennett-Longyear Association (Hibbing, Minnesota: Sargent Land Company, 1991).

147 Case and Schwaller, The Longyear Legacy, 12.

148 Torreano, Mesabi Miracle, 45 .

149 “Michigan: New Companies,” Engineering and Mining Journal 35(1883):48. 
To enhance the profitability of his holdings, Longyear acted as a booster by publicizing grand accounts of northern Michigan's potential. In 1884, he joined with J. M. Case to publish an account written under the nom de plume "Cary" of travelling through the Michigan's western Upper Peninsula that promoted the beauty of the region and its very bright commercial and industrial future. ${ }^{150}$ Cary wrote with unconstrained optimism "the water-power, the railroad shops, the foundations for manufacturing - everything is on a massive scale, and the indications are that here, in the near future, will be found a populous, prosperous city." Longyear and Case included their own detailed account of the mineral resources of the region, writing "In natural resources, Ontonagon County is excelled by no other county in the state of Michigan, or for that matter, by no other district of the same size in the world." The brochure then details Longyear's and his partner's iron lands in that county, points to possible gold and silver areas and concludes with an advertisement for their land services. Longyear also wrote an article in the local newspaper, The Gogebic Explorer, detailing gold assays made showing up to $\$ 1700$ per ton. ${ }^{151}$

Longyear's professional life reveals several patterns that are important in interpreting his landscape strategy on Spitsbergen. Firstly Longyear, often working with Ayer, preferred to control resource lands and profit from others working them rather than work them himself; he had only personally involved himself in opening one exploratory mine before 1905 which was very small-scale. His efforts to develop a profitable mining operation in Norway and Spitsbergen represent a clear break from that pattern, although

150 Forests, Streams, Lakes and Resources of Northern Michigan (Marquette, Michigan: J. M. Longyear and J. M. Case, 1884).

151 Eckrose, America’s Gogebic Range, 53. 
Longyear did have experience with mine opening and operation through regular inspections of the mines on his and his partnerships' lands.

Secondly, Longyear was skilled at gaining control of lands in newly discovered mineral regions before the bulk of investors had the chance to do so. In the US he obtained lands through purchases and partnerships while Spitsbergen's terra nullius status offered him and Ayer access to a great deal of land through claiming, a weaker form of ownership. Finally, Longyear's approach had been proven viable because it had been profitable in the US, sometimes extremely so. Each of the Menominee, Gogebic and Mesabi iron ranges grew to be successful mining districts and Longyear profited from them all.

While Arctic Coal Company documentation never directly details the company's strategy to develop and profit from the Spitsbergen landscape, the above shows that it went beyond the their attempt developing a mining operation, which historical accounts have typically focused on. Ayer and Longyear hoped to profit from this growing mineral region as they had repeatedly done in the US, by gaining a stake in its mineral lands and then offering that, in this case both their lands and mining operation, to others to work. The men had always planned to only work Spitsbergen's lands up to the point that they could place them on the market and did not sell specifically because of operational losses and the war, as commonly assumed. Their strategy was vague in that it was adaptable to the geological conditions on the ground, the events surrounding their efforts and the amount of resources the company could spare to prepare the lands for market but one contemporary second-hand reference attests to it being a distinct part of Ayer and Longyear's overall plans. A report coming from a 1913 expedition that visited the Arctic Coal Company at Advent Bay and investigated its operations describes a conversation with General Manager Scott Turner: "Messrs Ayer \& Longyear ... do not usually work 
mines. They acquire mining properties, prove their value, and then sell, and he thought they would be prepared to part with their mines in Spitsbergen.”152

\section{Bringing Longyear's Land Management Approach to Fruition}

The following three chapters describe the Arctic Coal Company's efforts to develop a mine on Advent Bay. In regards to the rest of their lands, the company established prospecting camps across them from 1906, each with a hut, some already standing and others newly built, work tools and supplies, and a small team of 2-4 men. They expanded their exploration efforts in 1907 with a camp in Coles Bay, at the east end of Tract \#1. Figure 7.1 shows the location of company prospecting camps across the Ice Fjord. More than providing information on local coal resources, the camps also served to assert the company's claims to the land by showing ongoing work and occupation. In this way they acted as silent actants with duel roles in the network. By 1909, the prospecting work provided enough information to estimate commercial value in mining, and the company abandoned four of its camps, at Coles Bay, Cape Boheman and two at Sassen's Bay, although they maintained their right to them. ${ }^{153}$

Armed with a better understanding of the local coal resources, the Arctic Coal Company focused on the claims with the greatest potential, Tract \#1 around Longyear City and Tract \#2 around Green Harbor. ${ }^{154}$ The company never systematically developed the

152 Atkinson, J. B., Spitsbergen Coal, 1913, Riksarkivet, Spetsbergenarkivet, vol. 4. Stockholm, Sweden.

153 Arctic Coal Company General Manager's report for the year ending October 27, 1910, Michigan Technological University Archives and Copper Country Historical Collections, Longyear Spitsbergen Collection (MS-031), box 4, folder 23.

154 Detailed in the company's annual reports, Michigan Technological University Archives and Copper Country Historical Collections, Scott Turner Collection (MS-018) and Longyear Spitsbergen Collection (MS-031). 
Green Harbor tract, preferring to prospect and slowly mine one seam. That work provided useful data on the nature of the coal there, which at first suggested it was a promising mining area. As mining continued, however, the seam at Green Harbor began showing increasing signs of stone inclusions, and rolling and folding that would pose significant problems for large scale mining. ${ }^{155}$ By the later years, the work there became almost symbolic in that it sustained their claim against numerous competitors while working at a continual financial loss and selling little coal.

In 1908, the Arctic Coal Company opened mine 1 on the slopes above its 4-man hut in Green Harbor. In 1909, it built a larger hut for 11 men and opened a new mine, mine 2, less than mile to the south. In 1911, it added a provision house and stable adjacent the barracks to improve its facilities there. The company vigorously defended this claim in political circles with detailed accounts of 'trespassers' and annual reports detailing the development progress made. In 1912, general manager Scott Turner urged that the company come up with a clear plan for the tract to either develop it systematically or abandon it. Longyear advised him to continue the work without change. ${ }^{156}$

The value of Ayer and Longyear's land holding strategy steadily declined as the men gained more information about local geology and as others challenged their rights to the land. The land claims also proved to be a burden on the company. Even though Spitsbergen's land was theoretically free to claim, the cost to hold them proved large. Ayer and Longyear funded the erection of prospecting camps and paid teams to test the lands. Since the whole Spitsbergen venture was tightly budgeted and got supplies from a

155 Scott Turner, 'Ayer and Longyear - Green Harbor Tract. Reports Covering year 1913 - 1914,' Michigan Technological University Archives and Copper Country Historical Collections, Scott Turner Collection (MS-018), box Z, folder Z36.

156 Dole, America in Spitsbergen, ii, 168-9. 
limited number of ships in the summer season, these prospecting camps took men, materials and management's attention away from the struggling Advent Bay operations.

The greatest capital cost associated with the three land claims was for legal expenses. From at least 1907 to the sale of the company, the Arctic Coal Company hired a lawyer out of Washington D.C., Nathaniel Wilson, to assist it with their dealings with the State Department and other legal issues. Wilson was expensive, costing the company $\$ 5000$ per year. ${ }^{157}$ The bulk of Wilson's work related to the Arctic Coal Company's efforts in negotiating favorable terms in discussions over the national status of Spitsbergen. Two of the claims, \#2 and \#4, overlapped earlier Norwegian land claims and in time numerous groups made claims over Arctic Coal Company claims. To bolster their political position, the Arctic Coal Company sent extensive annual reports to the US State Department, detailing the activities of that year, precise descriptions of their claims and their efforts to hold them, declarations from witnesses and so forth. Longyear used his contacts in the federal government to lobby senators, the secretary of state and other officials to their cause. ${ }^{158}$ Although it is only possible to speculate, Ayer and Longyear probably would have required far less legal representation if they had concentrated on their purchased lands, tract \#1.

At several points the General Managers of the Arctic Coal Company suggested to Longyear that the company abandon these three land claims and focus on Tract \#1. In 1913, facing an annual loss of $\$ 5000$ at the Green Harbor claim and mine alone, Scott Turner argued that the Arctic Coal Company withdraw from all these claims and

157 Letter from Scott Turner to J. M. Longyear, September 8, 1914. Michigan Technological University Archives and Copper Country Historical Collections, Scott Turner Collection (MS-018), box CE, folder CE1O.

158 Singh, The Spitsbergen (Svalbard) Question. 
concentrate on Advent City. Yet Ayer and Longyear persisted, based on a few rationales. Wilson advised them that abandoning claims would weaken their overall political position and they should therefore maintain all claims. ${ }^{159}$ The Sassen Bay and Cape Boheman tracts had little commercial value but they also attracted little competition over their ownership. Since the company had already placed claim signs and built huts there and were no longer testing them, they would require little funding to hold. They continued to hold onto and operate the Green Harbor claim in part to maintain their political negotiating position for all their lands but also to continue their effort to bring the lands to market.

By 1913, Ayer and Longyear felt that their Advent Bay operations had reached the end of its exploratory phase and set the groundwork for larger operations. ${ }^{160}$ Their Green Harbor tract also offered opportunities for development and could be offered to the market independently of the Advent Bay tract. From that time forward, the Arctic Coal Company pursued opportunities for groups to purchase or lease the tracts, or to form partnerships with others to further develop them, just as Longyear had done with his Lake Superior holdings. Unlike the booster approach he had used to advertise lands on the Gogebic iron range, Longyear took a more subdued approach to promotion of his holdings here, using language that almost excused the state of the development. In a letter to Scott Turner detailing his preferred course, he wrote "To parties coming to investigate the property we should insist that we do not consider the mine we have

159 Dole, America in Spitsbergen, ii, 250.

16o Several documents refer to this sentiment. In one example, Longyear wrote to Scott Turner "Mr. Ayer feels disinclined to put in any more money than necessary to keep the matter going in reasonably good shape as an exploration," March 10, 1913. Michigan Technological University Archives and Copper Country Historical Collections, Scott Turner Collection (MS-018), box CB, folder CBo4. 
opened a mining proposition, it is simply an exploration to develop the possibilities of the seam of coal; that we consider all the work exploratory, and that we do not consider the mining equipment anything like a full outfit." 161

Scott Turner travelled extensively, promoting the lands and attempting to reach a deal. Initially, the efforts seemed promising as they attracted interest from parties from Norway, Russia, Germany, Sweden, Scotland and apparently even Italy, and the $\$ 2,000,000$ starting price for all properties would bring the owners a healthy profit. The outbreak of World War I, though, weakened the company's position as it drew national interest away from the opportunity towards the war while amplifying the company's costs and need to sell. The central power's navies threatened the safety of the company's ships, which transported men and supplies to Spitsbergen and coal to trading ports. The class of ship that the company leased each summer for coal transportation was now under heavy demand and significantly more expensive to use. The war made numerous goods difficult to get due to war provisioning and some critical technical components, such as aerial tramway parts that German companies fabricated, were impossible to procure. The Norwegian government also passed strict export laws that, when applied to the Arctic Coal Company, prevented almost all goods and men leaving Norway for Spitsbergen. ${ }^{162}$

In the war setting, only Norwegian and Russian interests remained likely investors. With effectively no domestic coal reserves and a dwindling supply from Germany and Britain

161 Letter from J. M. Longyear, President of the Arctic Coal Company, to Scott Turner, General Manager, March 10, 1913. Michigan Technological University Archives and Copper Country Historical Collections, Scott Turner Collection (MS-018), box CB, folder CBo4.

162 Letter from Scott Turner to the Arctic Coal Company, February 16, 1916, Michigan Technological University Archives and Copper Country Historical Collections, Scott Turner Collection (MS-018), box AA, folder 03. 
during the war, Norwegian political and commercial interests anticipated Spitsbergen as a potential national supplier. ${ }^{163}$ The Norwegian government also supported the move to help accomplish the long held desire to gain sovereignty over the archipelago. ${ }^{164}$ The Russian state also needed coal to supply its newly completed the Murmansk Railroad that reached north to the Barents Sea. ${ }^{165}$ For them, Spitsbergen's coal could be an ideal energy supply.

Recognizing Russia’s desire for a northern coal supply, a Scotsman, Leslie Urquhart, took an option on the property and attempted without success to sell it to the Russian government. Later, two Norwegians, Jonas Anker and Jonas Lied, took out separate options on Tracts 1 and 2 for purchase at $\$ 2,000,000$ and $\$ 60,000$ consecutively and offered them to the Russian government. Although interested, the Russians declined as they were then heavily involved in the war ${ }^{166}$ and because their mining geologist almost lost his life in pack ice travelling to inspect the mines, leaving him with a negative impression of the opportunity. ${ }^{167}$

Finally, the company negotiated with a Norwegian syndicate through Erling Einar Angell Thiis over the sale of all company lands. After extended negotiations that involved the

163 Turners article in Polar Encyclopedia ‘Mining in Spitsbergen’ Michigan Technological University Archives and Copper Country Historical Collections, Scott Turner Collection (MS-018), box $\mathrm{Z}$, folder 18 .

164 Berg, "A Norwegian Policy of the North before World War 1?,” 13-16.

165 Letter from Scott Turner to the Arctic Coal Company, July 21, 1915, Michigan Technological University Archives and Copper Country Historical Collections, Scott Turner Collection (MS-018), box CC, folder 13 .

166 Dole, America in Spitsbergen, ii, 407.

167 Letter from Scott Turner, general manager of the Arctic Coal Company, to the Arctic Coal Company, October 2, 1915, Michigan Technological University Archives and Copper Country Historical Collections, Scott Turner Collection (MS-018), Box CC, Folder CC13. 
prime minister of Norway, Ayer and Longyear sold to the Store Norske Spitsbergen Kulkompani Aktieselskab, soon named Store Norske Spitsbergen Kulkompani. The Arctic Coal Company's mining operations were by far the most valuable component of the sale and the land claims played only a sideline role. Ayer and Longyear's plans to use their land claims to profit from the rise of a new mining region largely failed to come to pass.

The terms of sale were for Kr.1,500,000 and Kr.2,000,000 of common stock (around $\$ 1,000,000$ value combined), excluding commission and the sale of goods in the company's warehouses, with a $5 \%$ commission in exchange for all Arctic Coal Company assets, and Ayer and Longyear's three land claims. ${ }^{168}$ The company sold its warehouse goods to the syndicate for Kr.99,000 and its ship, the S. S. William D. Munroe, to another buyer "at good advantage." 169 The deal permitted the Norwegian stockholders of the Arctic Coal Company to exchange 270 shares for Kr.1500 of common stock in the new company. In 1915, the Arctic Coal Company sold their Tromsø staff house for $\mathrm{Kr} .17,300, \mathrm{Kr} 4,800$ more than they had paid. Independently of these dealings, an English shipping firm bought the Kwasind from the Arctic Steamship Company for $£ 35$,ooo, or around $\$ 170,000$, well above the initial purchase price and the amount anticipated. ${ }^{170}$

Nathan Haskall Dole estimates the losses to Ayer and Longyear from the Arctic Coal Company at US\$240,000 when treating the shares in the new company at par value.

168 Dole, America in Spitsbergen, i, 435.

169 Ibid., ii, 420, 383-4.

170 Letter from Scott Turner to the Arctic Steamship Company, December 18, 1915, Michigan Technological University Archives and Copper Country Historical Collections, Scott Turner Collection (MS-018), Box CC, Folder CC1329. 
Their investments in the Arctic Steamship Company, a company Ayer and Longyear formed in 1912 to manage the ship 'Kwasind,' went some way to make up this loss as they made considerable profits leasing the ship in the European shipping market, especially during the war when leasing rates rose considerably, and with its sale at considerable profit. This dissertation project found no summary of the profit of the Arctic Steamship Company but Ayer and Longyear probably lost from $\$ 100,000$ to $\$ 200,000$ combined in Spitsbergen.

\section{Conclusions}

Historian Nathan Haskell Dole maintains that Longyear's thoughts on investing in Spitsbergen's mineral lands started when he first visited the archipelago on vacation in 1901. Yet the above analysis shows that this is inaccurate. The assertion is false because Longyear first considered the archipelago commercially later. More importantly, Dole's argument suggests that Spitsbergen's coal resources initiated Longear's interest in the region's commercial potential. In fact, Spitsbergen was at most a background element in Longyear's plans until late in his investigations of a different mineral field.

Longyear's method for considering the minerals of Arctic Norway and Spitsbergen differ from his approach to the iron lands of the US, which is critical in explaining how he came to and developed Spitsbergen. In the US, Longyear and his partners almost always focused on managing mineral lands, rather than working them. In northern Norway and Spitsbergen, Longyear was primarily interested in developing a mining operation and paid less attention to the potential to control large areas of lands. Longyear and his associates developed three hypothetical mining networks, each a progression on the last. The first surrounded a high-quality direct shipping iron ore in northern Norway. On 
finding the ore to be lower quality than they had been led to believe, the men tried unsuccessfully to bring together the actants needed in an ore mining and concentrating operation: investors and consumers, iron lands, ore concentrating technology and the lime and coke needed to operate it. Longyear investigated Spitsbergen as a potential source of coking coal but after doing so decided the archipelago could easily support a profitable, stand alone enterprise.

William Munroe's interaction with the Spitsbergen landscape expresses Ayer and Longyear's strategy to profitably develop the landscape. Their first priority was to develop a profitable mining operation, which was the first task Munroe undertook on their behalf. They also attempted to control large areas of mineral lands, as was their typical practice in the US, by claiming large areas around the Ice Fjord. Ayer and Longyear planned to fund work on Spitsbergen temporarily before putting both the land claims and the mining operation on the market for others to lease, buy or partner in developing. When the men began seeking investors in 1913, the mining operation was easily the most valuable part of their Spitsbergen holdings. Their hopes in profiting from the land claims had slowly diminished as they found two claims below commercial value and the third, the Green Harbor tract, of only moderate worth. No investors expressed interested in leasing the claims, which eventually became a secondary feature in the sale of all Arctic Coal Company holdings to a Norwegian syndicate of investors. 


\section{CHAPTER 4}

\section{The Evolution of the Arctic Coal Company's Technical System}

\section{Introduction}

When Fredrick Ayer and John M. Longyear decided to pursue the Spitsbergen coal mining opportunity, they needed to transform their hypothetical vision of a coal mining network into an actual one. The idea of mining coal and transporting it to nearby ships, which seemed simple on paper, needed to confront Spitsbergen's environmental, technical and commercial realities. The seemingly endless market for coal in Norway needed to become actual orders from paying customers. Almost every element of the enterprise proved more complex and difficult than originally anticipated and the enterprise never met initial expectations despite the heavy investment made in it.

The company's technical system surrounding its mining operations in Advent Bay is the second major element considered in this dissertation. To understand the company's network building efforts, the technical system is first considered as a complete unit, showing how the system expanded over time to identify the broadest aspects of the company's development strategy and methods for overcoming problems. The actants that were the most difficult to rationalize into the network are then examined in greater detail, showing how the company responded to them, their success in doing so, and the role of the Arctic environment in the process. The difficulty of maintaining the operations as a functional unit is explained by detailing the effort necessary to keep its individual components working properly as a system. 


\section{The Evolution of the Arctic Coal Company's Technical System}

Over its existence, the Arctic Coal Company gradually installed a technical system that mined, stored and loaded coal. The author divides that process into three phases of development: 1905-1908; 1907-1911; and 1912-1915. Technological and operational change is summarized with minimal attention to the company's main mine since this has been thoroughly researched in previous work. ${ }^{171}$ The work brings a narrative to how and why the company made certain choices that is lacking in existing literature and even most of the archival accounts since company letters and reports often provide a patchy view on the broader context to change. To develop the narrative, the author reconstructed the company's technical system using photographs and documentary evidence during each year of operations and analyzed these for changes and broad themes of development. In this document, three maps present the physical layout of the Arctic Coal Company's wharfing and storage area at the close of each phase. For spatial accuracy, the layout is based on a measured 1912 Arctic Coal Company plan of that area. ${ }^{12}$ Electrical wiring has been left out of the diagrams since they would distract the reader from the core message of the images.

\section{Phase 1 (1905-1908): Establishment of Core Components}

In this period, the Arctic Coal Company established the central components of technical system. Between 1905-6, the company claimed four large tracts of land and William Munroe located the company's core infrastructure: the mine, the town, the dock and an

171 DePasqual, "Winning Coal at $78^{\circ}$ North.”

172 Michigan Technological University Archives and Copper Country Historical Collections, Keweenaw Digital Archives, MSo18-Z-13-01. The name 'wharfing and storage area' is a creation of the author. The Arctic Coal Company did not have a specific name for this area. 
aerial tramway system. From then until 1908, the company focused its efforts on constructing the main technical components of the system to allow full operations to begin. It was not until Phase 2 that the company could test this system as a functional whole.

Munroe began by continuing the Trondhjem-Spitsbergen Kulkompagni’s efforts, concentrating on the slopes facing Advent Bay while also lightly inspecting the larger landscape to clarify the consistency of the coal seams in the area. He continued a mine they had already started but found the coal distorted and broken and the mine poorly situated for future large-scale development. ${ }^{173}$

Munroe had little training in coal mining 174 and his 1905 workforce, a collection of nine sailors, ten Scandinavian laborers as well as firemen and assistants, possessed almost no mining experience whatsoever. ${ }^{175}$ As a result, he focused on the general matter of mining and looked to coal specialists for assistance with coal related matters. He soon befriended a man who could help him, Arthur Mangham, coal engineer for the Spitzbergen Coal and Trading Company working across Advent Bay. In August 1905, Mangham wrote a rough report on the coal lands for Munroe that agreed with Munroe's assessment of the Trondhjem-Spitsbergen Kulkompagni mine and assessed the area's

173 Letters from William Munroe to J. M. Longyear, Statsarkivet i Tromsø, Arctic Coal Company Collection (Privatarkiv Nr. 101), box 91. A team from Michigan Technological University and the University of Groningen found a number of these entries during a survey of this area in 2007. The form of the pits allows insights into the quality of work performed, the legitimacy of historic claims about the pits and the physical environment of past activities here, described in Ypie Aalders et al., LASHIPA 4: Archaeological Expedition on Svalbard, August 2 - 25, 2007.

174 In September, 1904, Longyear suggested to Munroe that he visit coal mining areas, such as those in Colorado, to prepare for the possible operation in Spitsbergen. Letter from J. M. Longyear to W. D. Munroe, September 19, 1904. Statsarkivet i Tromsø, Arctic Coal Company Collection (Privatarkiv Nr. 101), box 91, folder '1903 - 1907 L.'

175 Letter from W. D. Munroe to Fredrick Ayer and J. M. Longyear, May 29, 1905. Statsarkivet i Tromsø, Arctic Coal Company Collection (Privatarkiv Nr. 101), box 91, folder '1903 - 1907 M.' 
coal as equaling any across the world. ${ }^{176} \mathrm{He}$ also suggested a simple mining system for the slopes of Advent Bay but Munroe never adopted it. Arthur Mangham continued to advise the Arctic Coal Company on coal mining to at least 1908. In 1906, Munroe asked Mangham's son, Bert Mangham, to hire some English miners for the company and hired him as the company's winter manager later that year. The two Manghams strongly influenced the development of the Arctic Coal Company's mining approach by bringing coal men, mining equipment and mining methods from around the vicinity of their home in Rotherham, adjacent to Sheffield, England. The Arctic Coal Company retained this English connection until Phase 3, when it turned to American men, equipment and methods.

At the end of 1905, after returning to the US for the winter months, Munroe had coal samples tested at his old college in Houghton, Michigan. Based on these results and likely based on advice from Bert Mangham and the English miners he hired for the company in 1906, Munroe decided to locate the future operations on a mountainside to the south-east, in a nearby valley soon to be called 'Longyear Valley.' 177 Munroe took advantage of local topographical conditions by sheltering the mine under a stone outcropping that gave better protection from moving soils and falling rocks than the drainages flanking it.

176 Report on the Arctic Coal Company lands by Alfred Mangham for William Munroe, August 26, 1905, Statsarkivet i Tromsø, Arctic Coal Company Collection (Privatarkiv Nr. 101), box 91, folder ' 1903 - 1907 M.'

177 Letter from William Munroe to the Arctic Coal Company, July 13, 1906. Statsarkivet i Tromsø, Arctic Coal Company Collection (Privatarkiv nr. 101), box 91, folder '1903-1907 M.' 


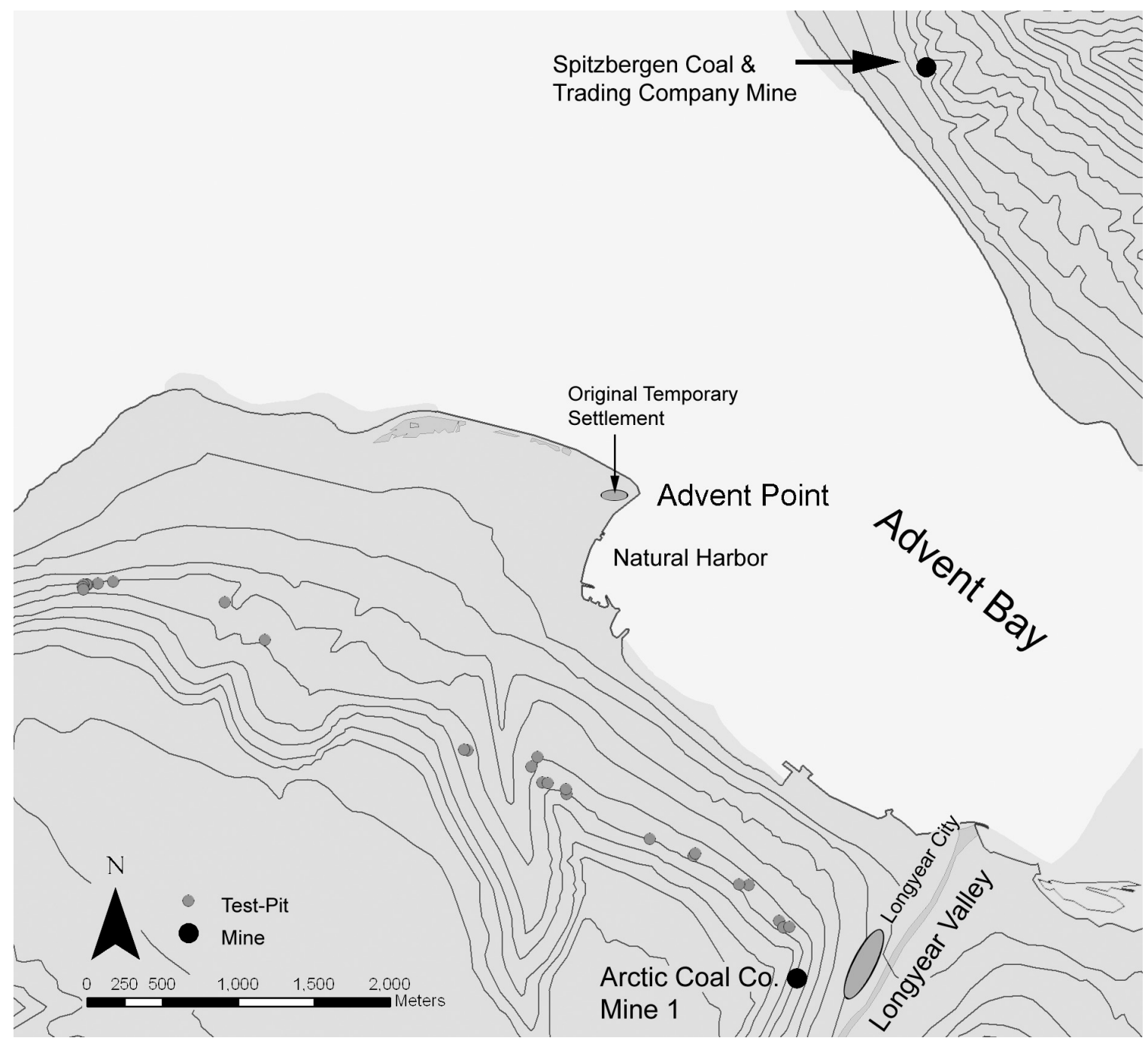

Figure 4.1 Map showing the location of test-pits overlooking Advent Bay, made by the Trondhjem-Spitsbergen Kulkompagni, Sir James Lamont and William Munroe, many of which the Arctic Coal Company continued as part of their ongoing geological studies. The Spitzbergen Coal \& Trading Company's mine, where Munroe found assistance for his planning efforts, is visible across the bay. Map by author, February 2009, using Data collected by a team from Michigan Technological University and the University of Groningen during LASHIPA archaeological survey in 2007, and Norsk Polarinstitutt base map information.

He also selected the seam the company would work. Since 1905, Munroe had tested three parallel coal seams across the landscape. Initially skeptical of Seam \#2, he 
considered other seams at first, ${ }^{178}$ but he changed his mind in 1906 and decided to work Seam \#2. ${ }^{179}$ Munroe's choice proved wise as he selected the coal seam that remained the primary focus of mining in this area for the majority of the century. By using a broad prospecting strategy, scientific analysis, taking his time and by drawing on the experience of his English miners, Munroe avoided the mistake made by the Spitzbergen Coal and Trading Company which had selected a fourth seam of an entirely different geological formation that held coal filled with impurities. ${ }^{180}$ Seam \#2 is today known as the 'Longyear Seam.'

Munroe chose the location of all other major infrastructure components of the operations based on the positioning of the mine. Munroe ran a narrow gauge rail line down to the valley floor so the workforce could transport goods up to the new mine location. He selected a site for a new dock at the foot of the valley. In doing so he abandoned the deep natural harbor initially intended for the company ships. He planned for a coal hopper with a 1100 ton capacity located a little below the mine. Below the hopper he planned an aerial tramway to connect the mine with the dock. ${ }^{181}$ Figure 4.2 shows the layout of the company's major infrastructure.

178 Letter from William Munroe to the Arctic Coal Company, December 27, 1905. Statsarkivet i Tromsø, Arctic Coal Company Collection (Privatarkiv nr. 101), box 91, folder '1903 - 1907 M.'

179 Letter from William Munroe to the Arctic Coal Company, July 13, 1906. Statsarkivet i Tromsø, Arctic Coal Company Collection (Privatarkiv nr. 101), box 91, folder '1903-1907 M.'

180 Avango, Dag., Patrick Martin, Larry Mishkar, Ian West, Miles Oglethorpe, Gustav Rosness, Susan R. Martin, Industrial Heritage in the Arctic: Research and Training in Svalbard, August 2004 (Houghton, USA / Stockholm / Groningen: LASHIPA, 2006), 36-7.

181 Arctic Coal Company General Manager's Report for 1906, US National Archives II (College Park), Department of State Papers, M862 (3746), Roll 342. 


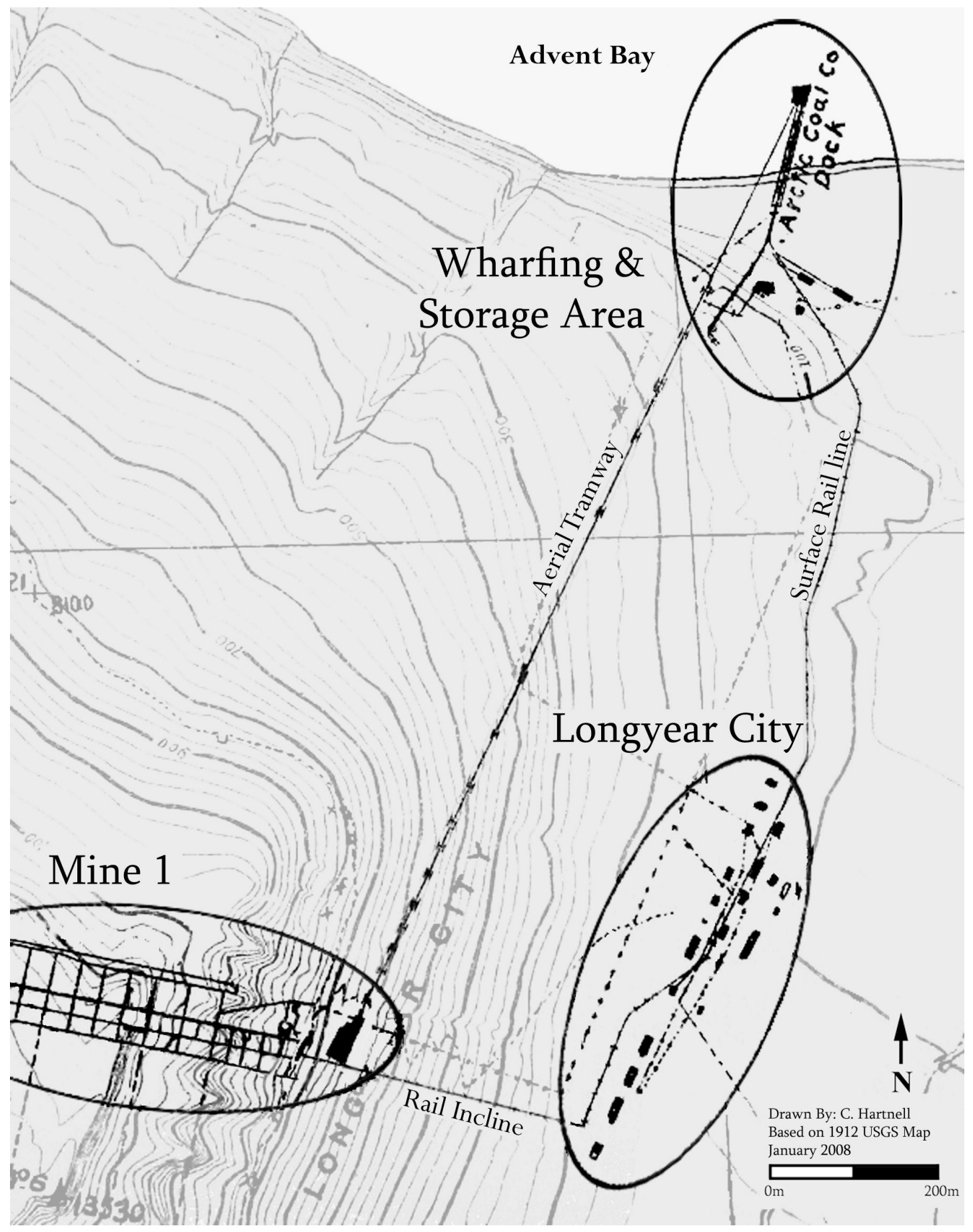

Figure 4.2 Map showing the layout of the major components of the Arctic Coal Company's operations on Advent Bay. Map by author adapted from 1912 USGS map by Thomas H. Moncure, Michigan Technological University Archives and Copper Country Collection, Michigan Technological University, Keweenaw Digital Archives, MSo18-Z-27-01. 
Once these formative choices had been made, Munroe again chose a strategic way to move forward, which was continued by his successors. He concentrated the majority of the Arctic Coal Company's efforts on the most central aspects of mining coal: the mine, coal hopper, aerial transportation system and the dock. ${ }^{182}$ He gave less attention to less crucial infrastructure such as the rail network, both inside and outside the mine, which he had built to a light narrow gauge and erected them quickly and cheaply. The company left other important infrastructure aside all-together, including but not limited to a power plant, warehousing and a wireless station to communicate with the mainland. Figure 4.5 shows the focused construction work made by the company in the wharfing and storage area adjacent Advent Bay by 1908.

This approach followed a common pattern for development of American mines at the time. Across the United States, speculative mining operations generally invested in their mines over amenities and accommodations in their early years. Richard Francaviglia refers to this as the formative stage of development. ${ }^{183}$ Once a mining operator became more confident in their mine's future, more money was generally invested to make their sites more permanent and more comfortable for workers, a pattern seen in here in the later phases of development.

182 Arctic Coal Company Annual Reports / General Manager's Reports for 1906, 1907 and 1908, US National Archives II (College Park), Department of State Papers, M862 (3746), Roll 342.

183 Francaviglia, Richard V., Hard Places - Reading the Landscape of America's Historic Mining Districts (Iowa City: University of Iowa Press, 1997), 151. 


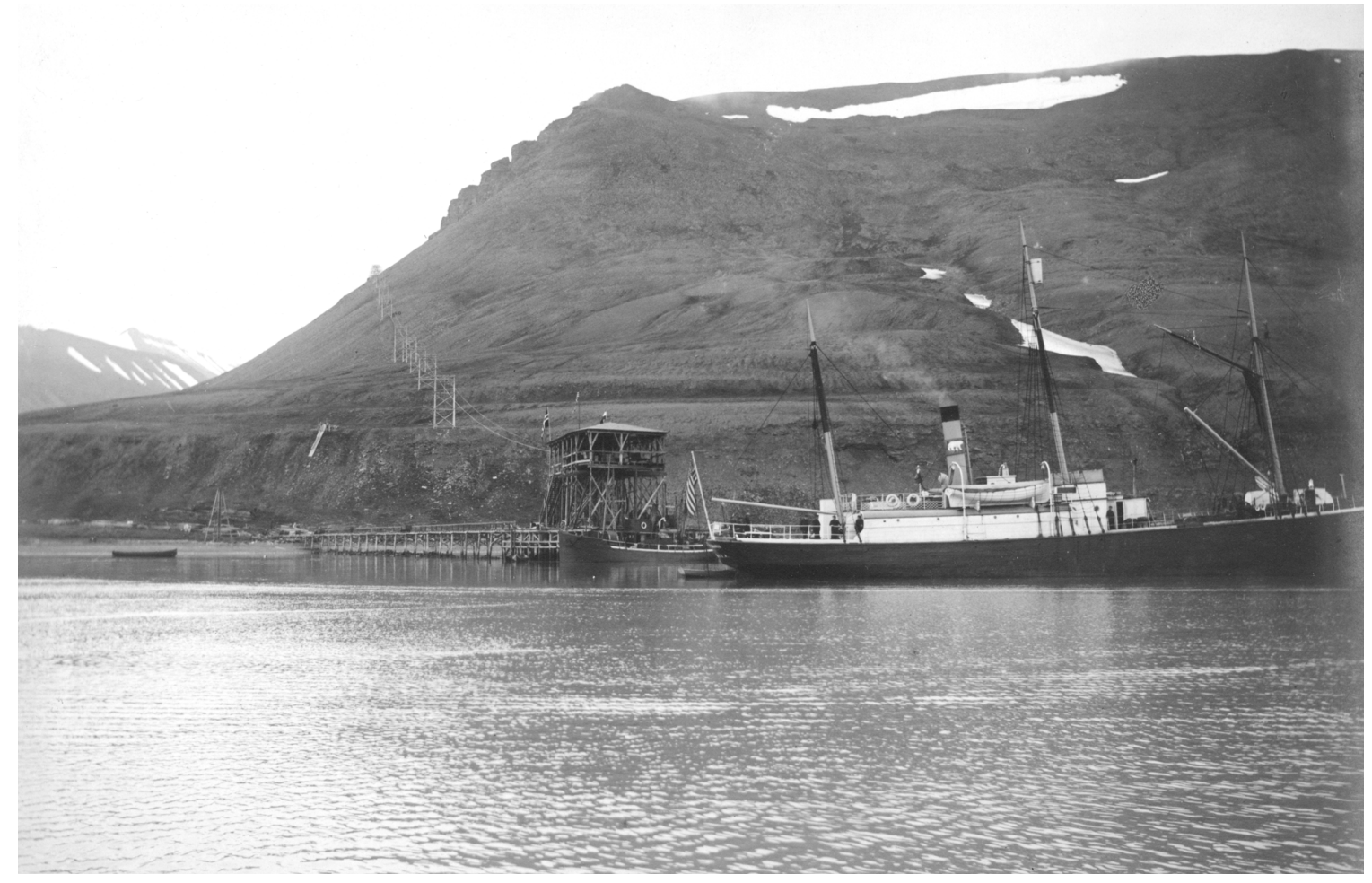

Figure 4.3 The site in August 1908 after the completion of the dock and aerial tramway. The company ship, the S. S. William D. Munroe is at anchor in front of a whaling gun boat moored at the dock. Photograph by Anders Beer Wilse, 1908. Michigan Technological University Archives and Copper Country Historical Collections, Michigan Technological University, Keweenaw Digital Archives, MSo31-01-01-10.

The company had hoped to be operational by 1907 but numerous delays forced this back to the end of summer 1908. These years saw great disruption to the company's upper management as William Munroe drowned in February 1907 in the wrecking of the S. S. Berlin off the coast of the Netherlands. The accident caused considerable difficulties as it came during preparations for the upcoming summer's work. Longyear himself stepped in to help run the company and a frantic search in America quickly brought Kenneth L. Gilson to Europe to work as Superintendent. Gilson was a 26 year old graduate of the Pennsylvania State College who had experience in coal mining, surveying and drafting, and office work. He was also a Norwegian/American and thereby could communicate 
effectively with the Arctic Coal Company's seasonal Scandinavian workforce. ${ }^{184}$ This factor by itself strengthened the company's network as it allowed management to more effectively communicate with its labor force. In 1908, Ayer and Longyear settled on Fredrick Burrall to be the Arctic Coal Company's next General Manager. Burrall, born in 1872, was Longyear's wife's nephew and was well known to him. Like Munroe, he trained at the Michigan School of Mines and had experience in topographical survey and hard rock mining. He had little to no direct experience with coal mining. ${ }^{185}$

Work began on construction in late-summer 1906. The Arctic Coal Company pushed mine development hard, opening two adjacent adits in the hillside that would serve as the main heading and air heading. By the summer of 1908, Fredrick Burrall, then the General Manager, reported that the main adit and the return airway stood at a reasonably good length, 900' and 750' respectively, and the mine had a 900 foot coal face ready to work. Noting that other core infrastructure elements remained incomplete, Burrall diverted the remaining summer capacity towards completing those. In 1907 , the company purchased its final core facility, a company ship. Previously Munroe had hired ships at great expense and difficulty. This new ship, soon named the "S. S. William D. Munroe" in honor of the man, was an old wooden Norwegian whaling vessel that could carry men, good and supplies to Spitsbergen and coal from there. ${ }^{186}$

184 Letter from J. M. Longyear to W.F. Bentinck-Smith, secretary of the Arctic Coal Company, April 10, 1907. Michigan Technological University Archives and Copper Country Collection, Longyear Spitsbergen Collection (MS-031), box 4, folder 18.

185 Michigan College of Mines, Graduates of the Michigan College of Mines up to an including the class of 1909.

186 Dole, America in Spitsbergen. 


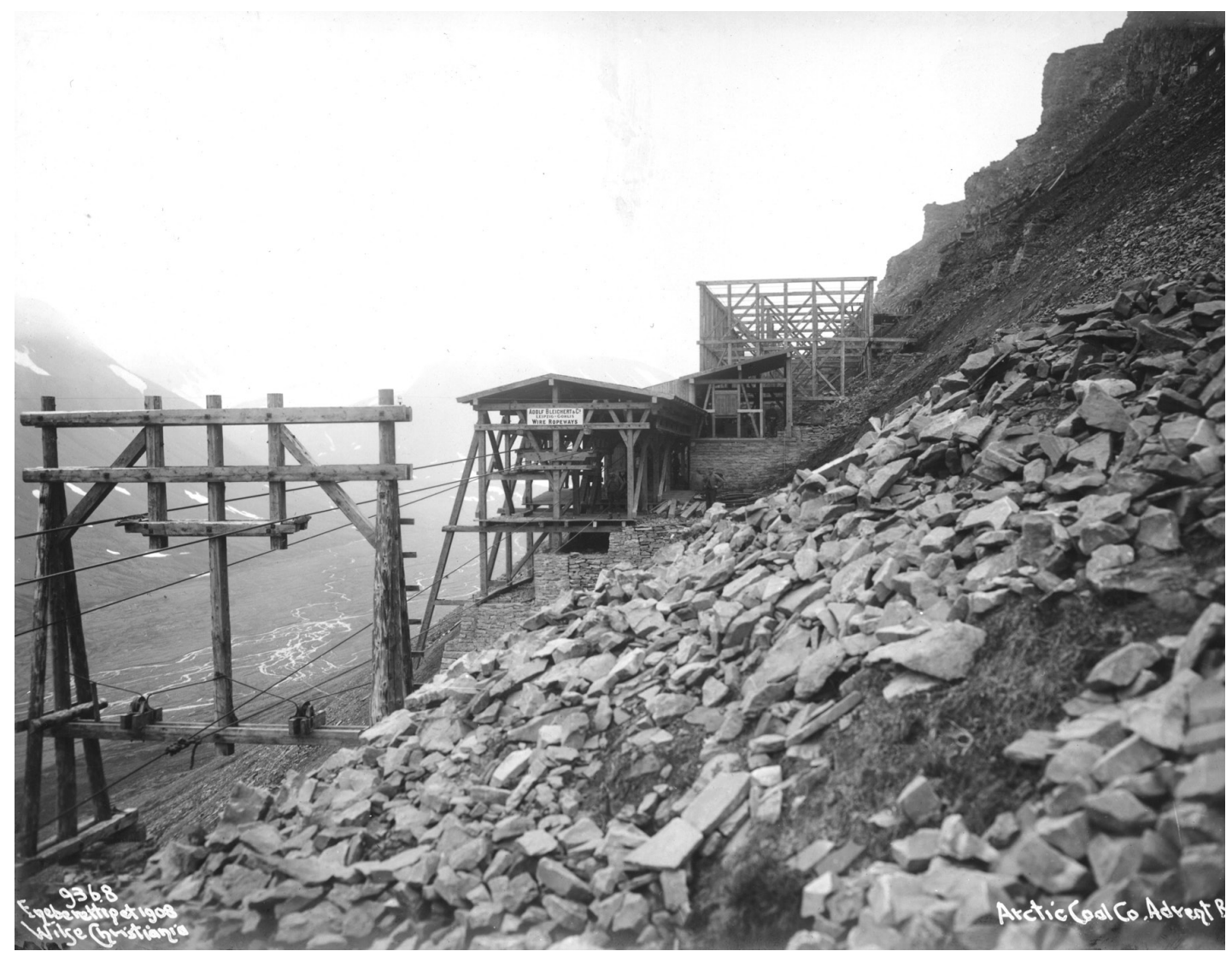

Figure 4.4 View of the aerial tramway, coal hopper (under construction) and part of mine \#1 (top-right corner) in 1908, looking south. Photograph by Anders Beer Wilse, Michigan Technological University Archives and Copper Country Historical Collections, Keweenaw Digital Archives, MSo18-007-02-12).

With little infrastructure available, the Arctic Coal Company was flexible in using that which it had. The rail system, from the mine through to the dock, although designed for transporting goods also transported stone and coal. The aerial tramway system, designed for delivering coal to ships, also transported equipment to the mine and waste rock to the dock. The company's ship rendered a versatile service rather than a specific one. It could carry both men and goods to and from Spitsbergen, could move under steam or sail and was small enough to berth at most ports. 


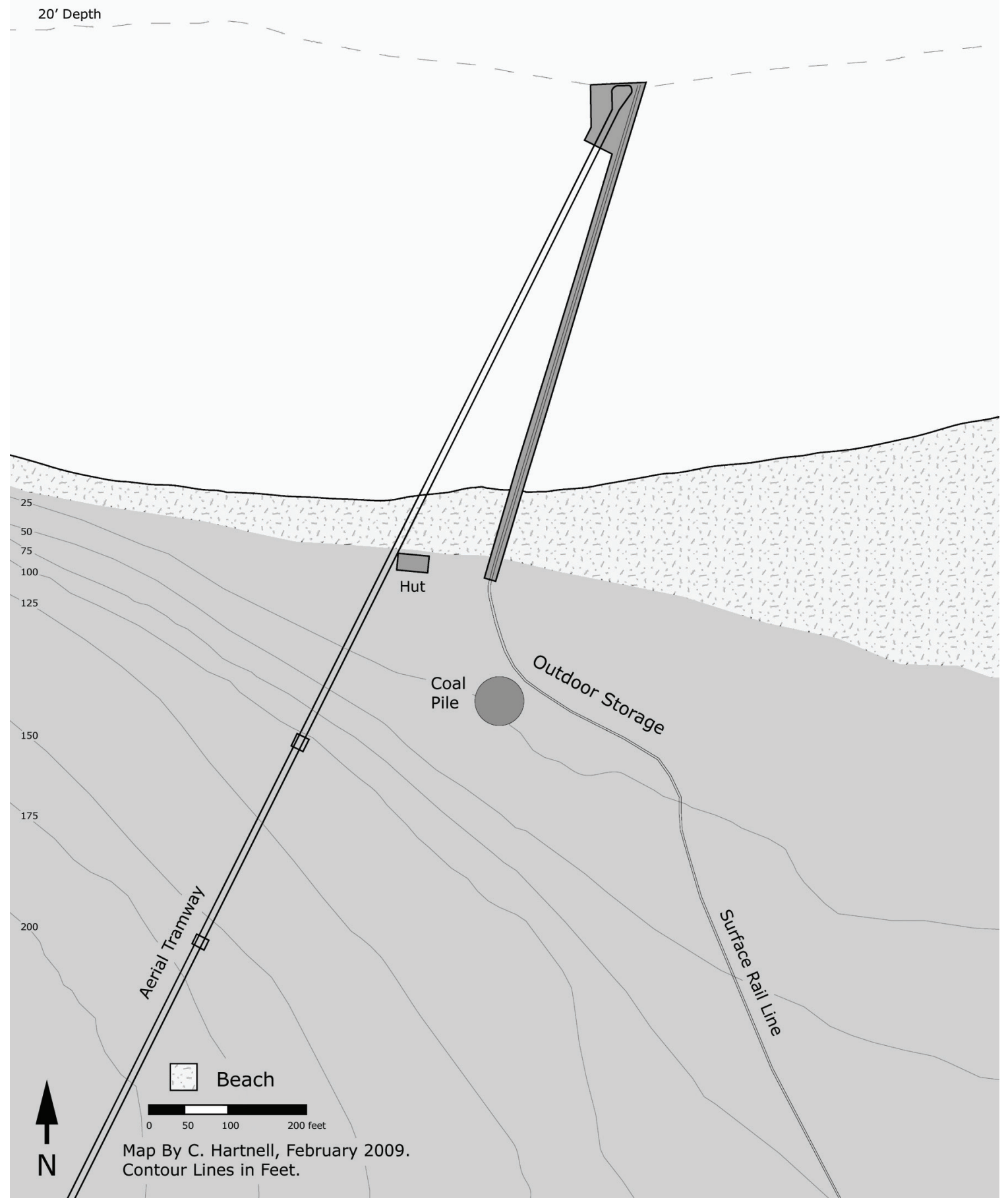

Figure 4.5 The Arctic Coal Company's wharfing and storage area in the summer of 1908. While core infrastructure is completed the company has invested little in other facilities. It stored many supplies outside and installed a simple narrow gauge rail line to wind up the hill. Map by author. 


\section{Phase 2 (1909-1911): An Operational Coal Mine}

"When Mr. Longyear went ashore, he saw a wonderful change. The party climbed up the steep zig zag to the mine. The length of the entry was 1350 feet. At one mine two thousand tons had been dumped from the bluff. All was activity and bustle and Longyear City was beginning to take on some proportions" 187

By the end of summer of 1908, the Arctic Coal Company had completed the construction of its major facilities and was operational. That winter's mining efforts made the first real test of the system, which started to demonstrate some of its inherent strengths and weaknesses. Plans for coal storage failed and larger problems with shipping became apparent. Powered by human and animal labor, the system worked slowly and inefficiently but proved itself sufficiently so that the owners continued investing with confidence. Based on professional advice, Ayer and Longyear again funded a significant upgrade to the operations that enhancing the existing system by broadening the industrial infrastructure surrounding it and improving existing facilities, while adapting the system to the constraints of Arctic environment.

Having reached their initial goals, the company contracted a Pennsylvania coal mining engineer, W. L. Coulson, to advise on the future development strategy and then visit their facilities in the summer of 1909, assess their current position and propose the best route forward. Burrall worked with Coulson to produced three proposals for the future shape of the mining operations in terms of powered machinery and speed of implementation. Ayer and Longyear chose to build a powerhouse to support electric

187 Mrs. Longyear recollection of John M. Longyear's visit to Spitsbergen in 1909, unnamed document, J.M. Longyear Research Library, 920 biographical folder. 
mining equipment, using a staged construction approach for completion by $1911 .{ }^{188}$ After close inspection of the Longyear Valley operations in 1909, Coulson concluded that coal seam \#2, while thin, was high quality and conducive to commercial mining. $\mathrm{He}$ recommended the company continue prospecting all coal veins in the area to firmly establish the real future potential of mining there. His investigation also confirmed that Longyear, Munroe's and Jeldness' initial beliefs about Spitsbergen coal were false. The coal here was "a strictly first class steam and domestic coal ... of the non coking variety." 189

Local conditions satisfied Coulson that a much larger mining operation was possible and he recommended a series of technological upgrades to equipment and approaches that he thought would allow the company to mine 200,00o tons annually at a cost of $\$ 110,000$. By expanding mine output, he said, the company could reduce production costs. He proposed the mine be expanded, electrified and its efficiency improved with a heavier rail network. Electrification would, he argued, stop hand mining and lower labor requirements. Correspondingly, with expanded mining, the company needed a larger and better designed settlement. He also advised that the dock and hopper were too light and needed to be strengthened.

One of the most important aspects of Coulson's work was his identification of a serious problem that strained the capacity of the network. The central difficulty facing the

188 Letter from Fredrick Burrall to the Arctic Coal Company, January 16, 1909. Michigan Technological University and Copper Country Historical Collections, Scott Turner Collection (MS018), box Z, folder Z24.

189 Report by W. L. Coulson, mining engineer, for the Arctic Coal Company, October 6, 1909. Michigan Technological University Archive and Copper Country Collection, Scott Turner Collection (MS-018), box Z, folder 11, 2. 
company, Coulson argued, "is more of a shipping problem, than a mining one." 190 The short summer shipping season forced the company to ship all its coal over a few months. Coulson proposed a technical solution to better rationalize the shipping actant into the network: the company should concentrate on building facilities that could load ships quickly and efficiently. Coulson's largest single expenditure proposal was for the construction of a second dock, estimated to cost $\$ 30,000$, to allow two ships to be loaded simultaneously. While the company adopted most of Coulson's recommendations, they ignored this key one, preferring to work with what they already had. Ayer and Longyear personally funded the upgrade of the operations, which were directed by Fredrick Burrall to early-1910 and by John Gibson, General Manager from 1910-1911. The company diverted attention from mining in 1910 to achieve these goals.

Prior to receiving Coulson's final recommendations, Burrall began to enhance the operations. On his arrival in the summer of 1909, he found that the Winter Superintendent, Bert Mangham, had stored the majority of mined coal on a bluff overlooking the dock, rather than following his instructions and storing coal inside the mine. Burrall quickly cut a temporary rail incline into the slope to the coal store where he had men fill rail cars manually and had a small rail incline installed at the end of the dock to raise the coal cars two meters to ships' sides. From this time forward, the company regularly upgraded this coal storage and delivery system to more efficiently store coal and load ships. These storage and shipping enhancements represent the first systematic adaptations of the network to Spitsbergen's Arctic environment, which forced the company to function on a summer/winter cycle, discussed in more detail below.

190 Ibid., 7. 
Also in 1909, Burrall built a concrete warehouse and the foundation to another in the wharfing and storage area. In late-1909, he laid a concrete foundation to the powerhouse and put out bids for its equipment in line with Coulson's recommendations. Gibson completed the powerhouse in the summer of 1910. It was a significant development for the site as it improved working and living conditions, allowed power machinery to be used in the mine, provided light for outdoor winter work and gave the Arctic Coal Company the option of installing a wireless station. It also provided steam to a small winch house which moved rail cars along the dock and up the incline. Workers powered the equipment with coal stored on a separate coal pile on the bluff which dropped down a chute via a narrow-gauge rail line. ${ }^{191}$ The construction of both signal that the company had moved beyond a concentrated focus on core infrastructure to developing a broader industrial system.

The design of the powerhouse also shows the company's ignorance of construction on Arctic soils, which ultimately impaired the network. Burrall laid a thin foundation without anchoring it to the permafrost below. The whole foundation rested on loose soils in the active layer above the permafrost, which froze and thawed with the seasons. Within a few years, the foundation had started to fail under heavy power equipment and over moving soft soils, causing considerable operational disruption. Scott Turner learnt

191 Hartnell, Cameron, 'Arctic Coal Company Powerhouse' inventory card, in Hartnell, Cameron, Seth DePasqual and Patrick Martin Heritage Survey of the Arctic Coal Company, Svalbard: Svalbard's Environmental Protection Fund Final Report, (Houghton, MI: Michigan Technological University). 
from the problems and when expanding the powerhouse in 1913, he had the foundations dug deep into the permafrost. ${ }^{192}$

In 1910 Gibson directed the upgrade of the company's entire rail network, both inside and outside the mine, to a heavier grade 3' gauge line. Cutting and filling techniques gave the surface rail line a more direct and even route. Archaeological survey work uncovered evidence of water drains along the line, which speaks to the relative sophistication of the upgrade in comparison to the old line. ${ }^{193}$ Workers raised and upgraded the rail incline connecting the valley floor to the mine and added an electric motor hoist adjacent the mine. This incline now had the capacity to carry both goods and people to the mine, thereby reducing workers' travel time from 45 minutes to 3 minutes and improving the efficiency of the mine an estimated 10\%. The company also upgraded the rail access to the open coal storage area and added a steam crane to mechanize loading and a larger dock incline to improve the loading of ships. ${ }^{194}$

In the winter of 1910, having completed the majority of the upgrades, the Arctic Coal Company shifted its attention back to mining. For the year ending in summer 1911, the company produced 29,000 tons, up from under 7,000 the previous year. In the winter of 1911 to 1912, the company installed a small wireless station that allowed communication with the Norwegian mainland and then America via a Norwegian government station in

192 Arctic Coal Company General Manager's Report Covering Operations During the Year 19121913, Michigan Technological University Archives and Copper Country Historical Collections, Longyear Spitsbergen Collection (MS-031), box 4, folder 13.

193 Martin, Patrick and Larry Mishkar, "Arctic Coal Company Industrial Railways,” in Avango, D. et al., Industrial Heritage in the Arctic, 28-32.

194 Arctic Coal Company General Manager's Report for the year ending October 27, 1910. Michigan Technological University Archives and Copper Country Historical Collections, Longyear Spitsbergen Collection (MS-031), box 4, folder 23. 
Green Harbor, over twenty miles to the south-east. It also had the advantageous capacity to communicate with company ships when within range of Spitsbergen, allowing a more coordinated approach to shipping. ${ }^{195}$

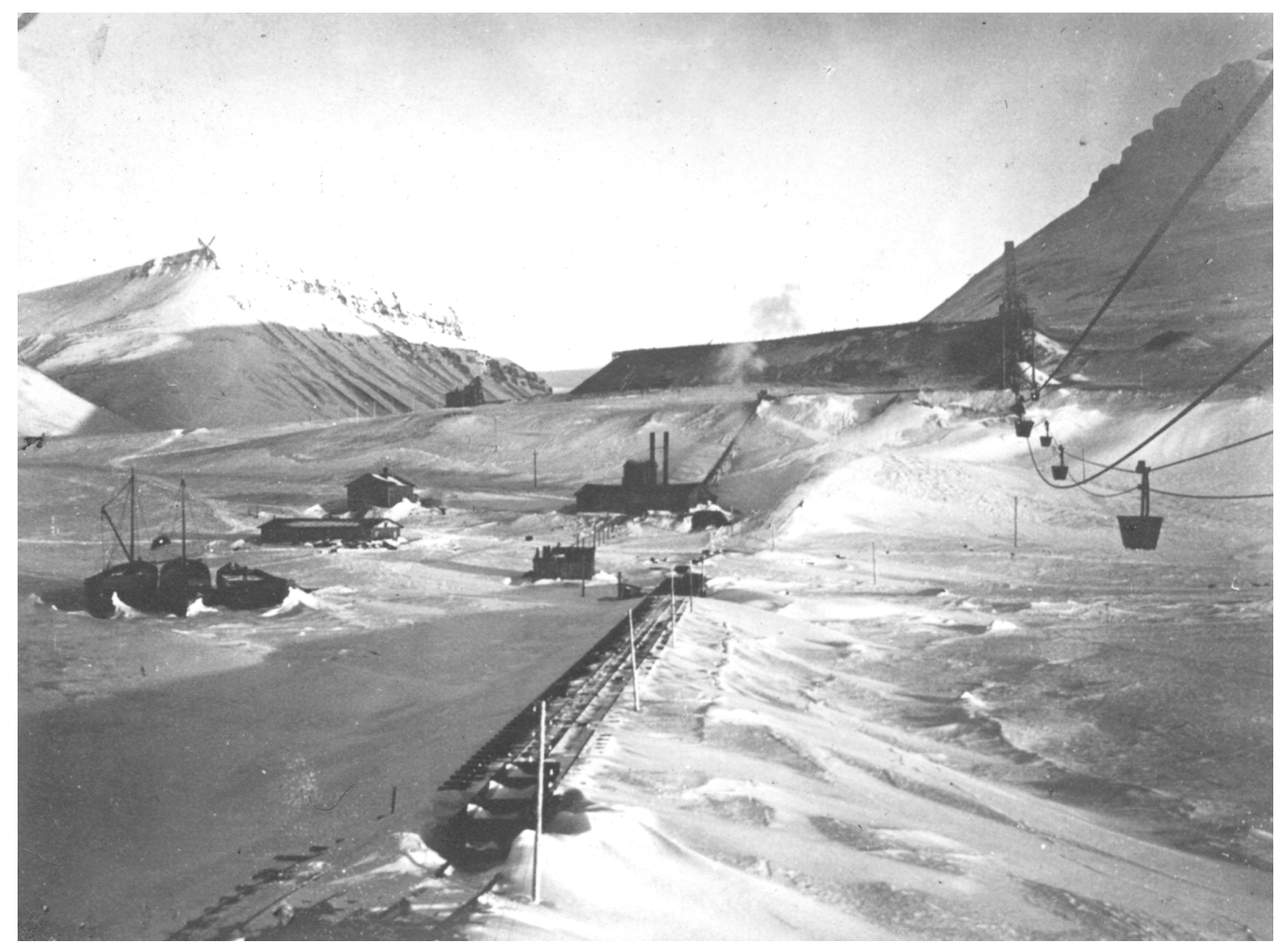

Figure 4.6: Photograph taken from the aerial tramway's lower terminal at the end of the dock in the early summer season of 1912. Note the much larger coal storage pile on the bluff above the dock. The photograph shows the difficult conditions that often met the first ship of the season. Michigan Technological University Archives \& Copper Country Historical Collections, Michigan Technological University, Keweenaw Digital Archives, Scott Turner Collection, MSo18-007-0202.

195 Arctic Coal Company Annual Report for the year ending October 17, 1911. Michigan Technological University Archives and Copper Country Historical Collections, Longyear Spitsbergen Collection (MS-031), box 2, folder 3. The negotiations over the wireless station reveal aspects of the serious political difficulties the Arctic Coal Company faced that continually threatened to dislocate its network. The political aspects of the company's history are analyzed in Singh, Elen C., The Spitsbergen (Svalbard) Question. 


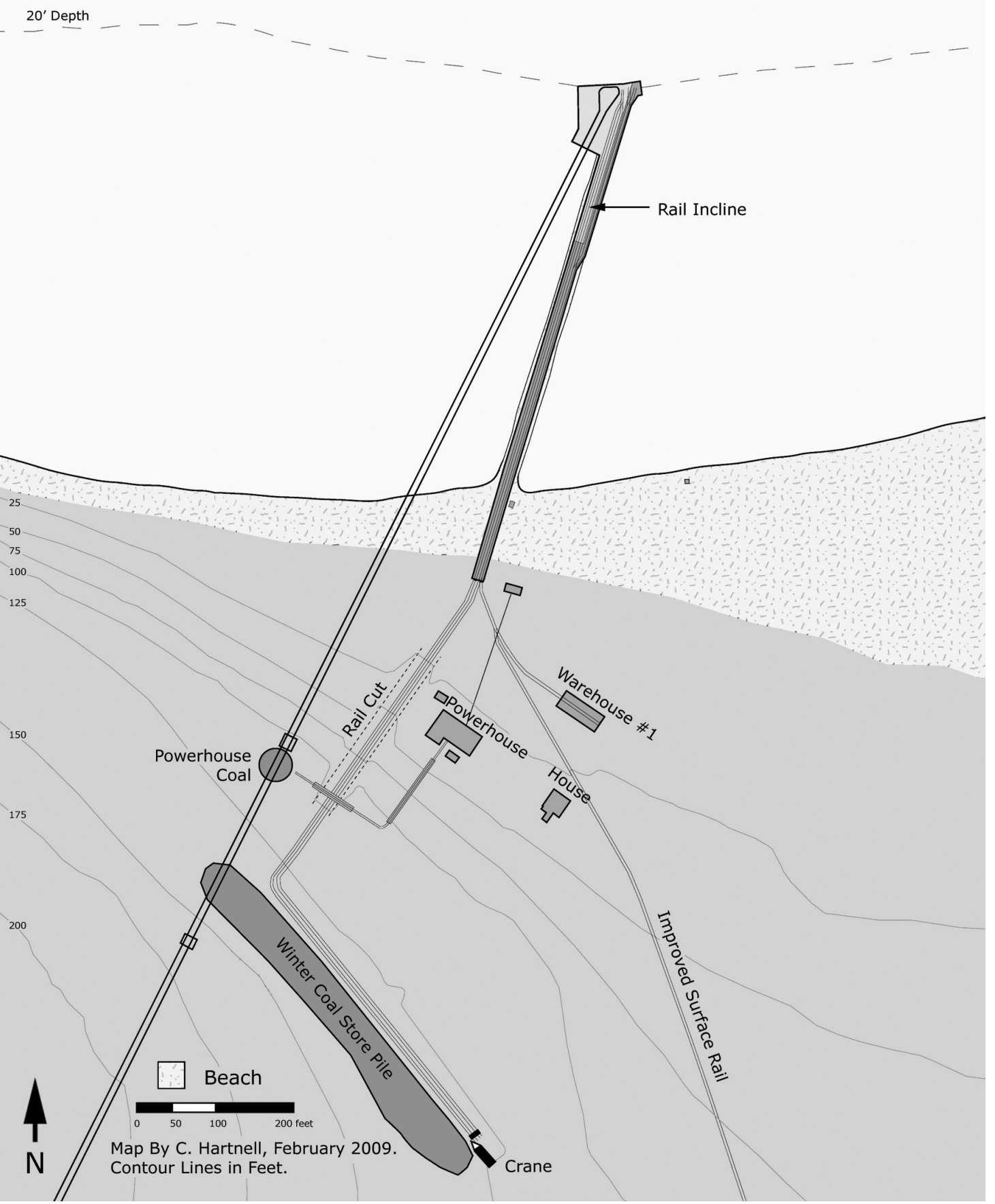

Figure 4.7 Map of the Arctic Coal Company wharfing and storage area in 1911 showing considerable changes from 1908, detailed above. The improvements expanded the company's industrial system and improved some features, including the surface rail line that is visibly straighter and more direct. These improvements fed into Munroe's original system and began to adapt it to the Arctic Environment. Map by author. 


\section{Phase 3 (1912-1916) Americanizing the Operations}

John Gibson resigned from his position in 1911 and Scott Turner replaced him later that summer. A strong character, Turner aggressively improved the site. In the company's annual reports he criticized the multiple use of equipment, the overdependence on manual labor and poorly constructed infrastructure as weaknesses in the network. ${ }^{196}$ Ayer and Longyear again agreed to fund a large upgrade to the company's facilities and, as in 1909-10, the investments focused on upgrading and expanding the existing system to improve efficiency. In the process, Turner pulled the company's system towards contemporary American methods, including single-use equipment and a preference for American equipment and management.

Turner agreed with Coulson's analysis that shipping presented a major problem for the company and put a considerable part of the company's energy towards addressing that issue. By this time, company management recognized that this problem went well beyond the speed of loading ships (more detailed explanation of shipping problems is provided later in this chapter.) In terms of physical changes at the site related to that challenge, he improved the coal storage facility, invested in a new ship and expanded the dock.

Turner upgraded the entire coal storage and transport system in the wharfing and storage area. He mechanized coal distribution on the winter coal pile by having the company design and install a temporary branch ropeway heading east off the main aerial tramway. Workers pulled down the ropeway each summer to allow the cranes to move

196 Archived in the J.M. Longyear Research Library, US National Archives II, and the Michigan Technological University Archive and Copper Country Collection, Longyear Spitsbergen Collection and Scott Turner Collection. 
the coal pile onto adjacent rail cars. The company still stored coal west of the ropeway by hand using rail cars. He also purchased a second crane and expanded the cut in the ridgeline and installed four parallel 3' rail lines over 1912 and 1913. Including the aerial tramway, the company now loaded ships by three relatively separate systems which reduced loading times from two or three days to one. Figures 4.8 and 4.9 show the layout of the wharfing and storage area towards the end of this period. Turner also installed weighing machines on the rail and ropeway systems at the dock to improve recording procedures. Exports had previously been weighed upon their sale. ${ }^{197}$

At Turner's prompting, Longyear purchased a new ship to join the company's fleet. A 400o-ton Great Lakes cargo ship renamed the 'Kwasind,' it gave them the ability to carry much larger loads of coal. Ayer and Longyear formed a new company to manage the ship, the Arctic Steamship Company, and leased it to the Arctic Coal Company during summer. Otherwise they earned money from leasing it in the European shipping markets. The ship's berth exceeded the capacity of the dock, forcing Turner to expand the dock into deeper waters. Although the ship could, and did, transport goods, people and coal, it represents a step by the company towards more specialized equipment. ${ }^{198}$

Turner expanded the company's covered storage capacity by building a new warehouses in 1912, 1913 and 1915. Turner expanded the dock's width to make rail lines used for

197 Arctic Coal Company Annual Reports/General Manager's Reports from 1912-1915, Michigan Technological University Archives and Copper Country Historical Collections, Turner Collection (MS-018), box Z, folders Z1-5.

198 Turner also proposed that the Arctic Coal Company purchase a versatile 10oo-ton ship to replace the Munroe in carrying goods, men and coal that would also serve in the European shipping trade when not used by the company, but this was not adopted. Arctic Coal Company General Manager's Report Covering Operations During the Year 1912-1913, Michigan Technological University Archives and Copper Country Collections, Longyear Spitsbergen Collection (MS-031), box 4, folder 13, 32-33. 
goods independent to those used for coal. All warehousing connected with surface rail lines that now ran to the dock's end via a line independent to the coal transport lines. ${ }^{199}$

In 1913, Turner expanded the powerhouse with a new wing and added a separate motor and generator that exclusively powered Longyear City. The changes were necessary as the powerhouse's foundation had failed and the machinery inside operated very poorly. Turner's addition had a well designed foundation and provided a reliable source of power. ${ }^{200}$ Even so, the powerhouse never supplied the enterprise with adequate power to operate all its functions simultaneously, forcing the company to run selectively and inefficiently.

The above changes, the improvements to coal loading and transportation, expansion of the dock for independent rail lines, the new ship and the powerhouse, all represent a shift towards specialized, single-use equipment. The extent to which Turner looked to specific contemporary examples to guide him is not known, but the change parallels approaches to manufacturing then being expounded in the United States. The 'American System' had developed during the nineteenth century and involved "the sequential series of operations carried out on successive special purpose machines that produce interchangeable parts." ${ }^{201}$ Although this definition describes a different type of industry, a connection between the nature of machinery is clear. Special purpose machinery

199 Arctic Coal Company Annual Reports/General Manager's Reports from 1912-1915, Michigan Technological University Archives and Copper Country Historical Collections, Turner Collection (MS-018), box Z, folders Z1-Z5.

200 Arctic Coal Company General Manager's Report Covering Operations During the Year 19121913, Michigan Technological University Archives and Copper Country Historical Collections, Longyear Spitsbergen Collection (MS-031), box 4, folder 13.

201 Ferguson, Eugene, as quoted by Hounshell, David, From the American System to Massproduction, 1800-1932 (Baltimore: Johns Hopkins University Press, 1984), 15. 
generally perform specific functions better than multiple use devices. Likewise, whole systems of specialized machinery, while functionally less adaptable, commonly perform particular operations more rapidly, efficiently and cheaply than adaptable systems. This approach was increasingly impacting American industry at that time, most famously with Ford's assembly line, then being perfected. ${ }^{202}$

Turner Americanized the organization in other ways. He began using American management and foremen rather than English ones. He even fired Winter Superintendent Bert Mangham, who had been a key player in designing the mine and installing mechanical equipment from the start. He preferred American manufactured machinery and goods over those from elsewhere and introduced American mining methods into Mine 1 alongside the original methods and only used American methods in a second mine the company prepared across the valley. ${ }^{203}$ Chapter 6 provides a more detailed account and analysis of this pattern of Americanization.

Turner instituted a much more rigorous system of accounting and documentation for the company. He analyzed the efficiency and cost of different parts of the system to a level never before possible, showing that American methods for mining resulted in significant savings per ton compared to the English approach. He found, with great satisfaction, that the daily coal output of his workers significantly outperformed the average output of

202 Lewchuk, Wayne, American Technology and the British Vehicle Industry (Cambridge: Cambridge University Press, 1988).

203 DePasqual, Winning Coal at $78^{\circ}$ North. 
miners British coal regions. ${ }^{204}$ The discrepancy is partly explained by the lack of mechanization in most British coal mines at that time. ${ }^{205}$

Ultimately, the accounting system allowed Turner to discern the strengths and weaknesses of the whole network in terms of cost and efficiency. By 1913, Turner could argue conclusively that the mining operations would never make a profit as it would lose around $\$ 1$ per ton even at times of high coal prices and regardless of the amount of coal mined. He found the mining operations working reasonably well. The coal storage, loading and shipping arm of the operations, while inefficient, fit within the general boundaries of a profitable operation. Mainly he concluded that the expense of operating in this isolated region, which he saw little potential to reduce, went beyond profitable limits. Should the company reduce that cost to more normal levels, he thought the operations might have generated a small profit. ${ }^{206}$ This situation testified to the partial success of the company in proving the viability of some aspects of mining on Spitsbergen but the overwhelming power of a single actant to disrupt the whole network.

\footnotetext{
204 Arctic Coal Company Annual Report for the year from June 1, 1914 to May 31, 1915, J.M. Longyear Research Library Archive, Spitsbergen Papers.

205 Church, Roy, The History of the British Coal Industry, Volume 3, 1830-1914: Victorian Preeminence (Oxford: Clarendon Press, 1986). Church estimates that the United Kingdom only produced $8.6 \%$ of its coal with machinery in 1913 .

206 Arctic Coal Company General Manager's Report Covering Operations During the Year 19121913, Michigan Technological University Archives and Copper Country Historical Collections, Longyear Spitsbergen Collection (MS-031), box 4, folder 13.
} 


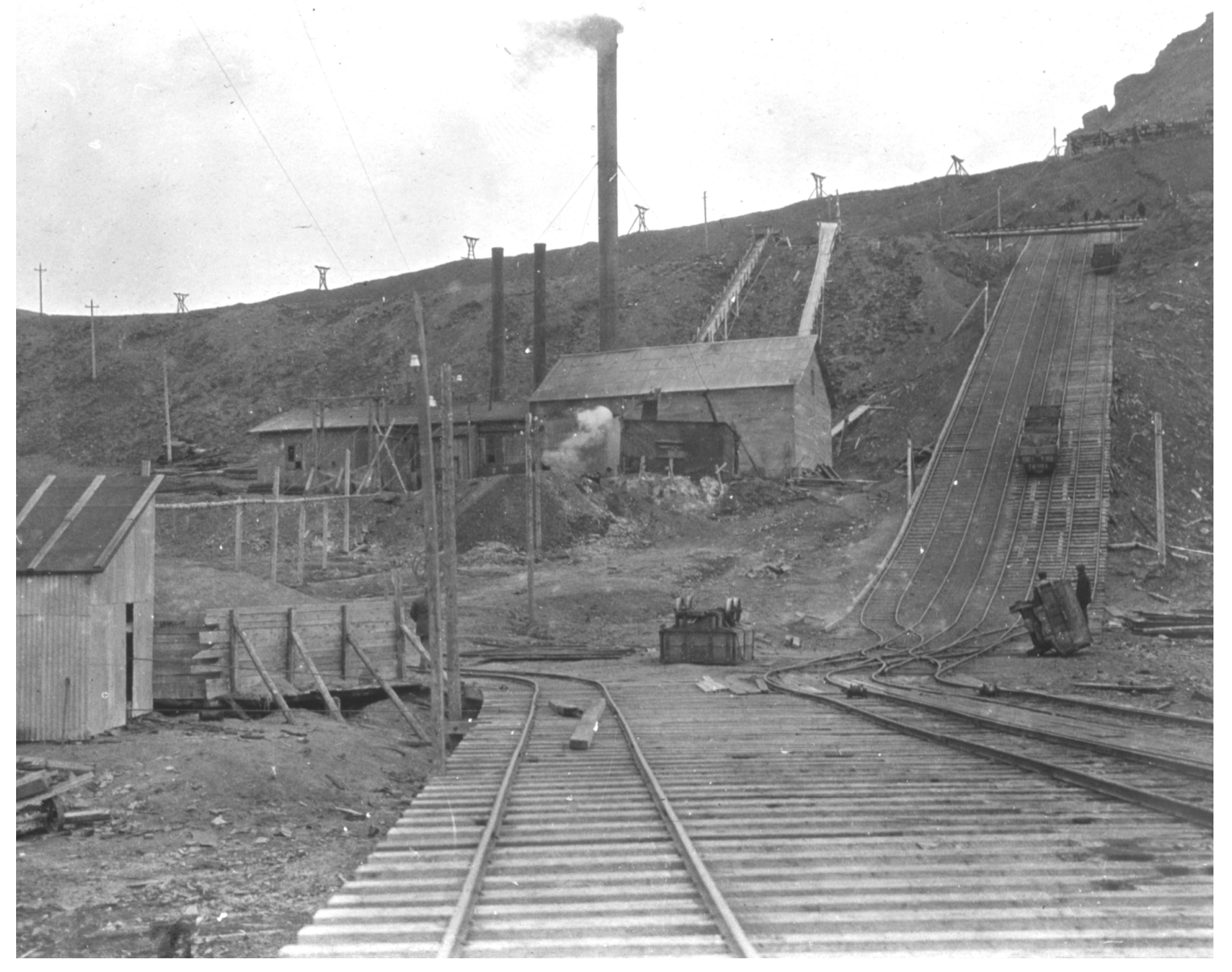

Figure 4.8 View from the dock to the expanded gravity incline to the coal pile and expanded powerhouse, taken between 1913-15. The branch ropeline that distributed coal on the coal storage pile is visible on the bluff above. The winch house building is the shed on the left. Michigan Technological University Archives and Copper Country Collections, Keweenaw Digital Archives, Michigan Technological University, MSo31-01-03-10. 


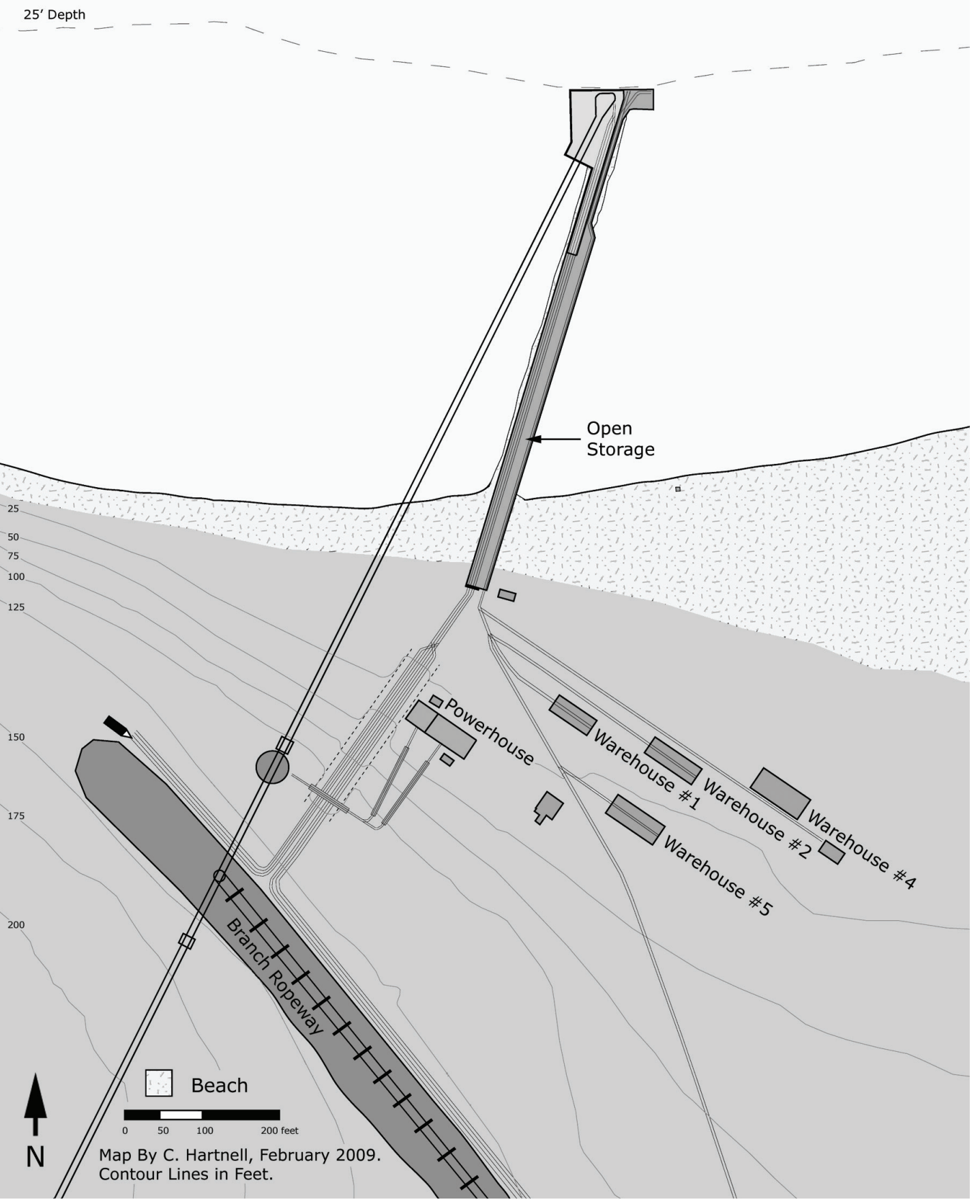

Figure 4.9 The wharfing and storage area in 1915. The two sections to the powerhouse, and separate coal and goods rail lines are now single-use only. Note the expanded dock that now reaches into deeper water to allow the company's ship, the Kwasind, to dock. At its most expansive, the winter coal pile stretched south-east to the edge to the edge of the natural bench. Map by author. 


\section{Analysis of Individual Actants in the Network}

\section{The Coal Storage and Delivery System}

The historical outline above shows that the company strategically evolved its operations from core facilities to a broader industrial network. In doing so, it continually built upon and enhanced its existing core infrastructure while rejecting more efficient, more permanent solutions that moved away from the core. Analysis of the company's approach to its coal storage and delivery system provides further insight into the reasons behind this evolutionary pattern.

Over its lifetime, the Arctic Coal Company rejected four proposals for managing its winter coal output and instead adopted and continued an approach that inefficiently handled coal and went against the specific recommendations of two General Managers. Up to the summer of 1908, the company's management made minimal plans for its winter coal storage, perhaps because the nature of the issue remained unclear before full operations commenced. Munroe's 1100 ton coal hopper outside the mine worked well with the aerial tramway but its capacity fell well below the projected mining output. In 1908 , lacking any storage structures, the company stored 2000 tons of coal in the open on the beach adjacent the dock. Based on that experience and on advice from the Spitzbergen Coal and Trading Company, General Manager Frederick Burrall argued that outside storage was inadvisable as some of the coal froze together and double handling was inefficient. He directed the Winter Superintendent to store the coal inside the mine and in the hopper, an approach that may have been a temporary solution as the mine would not have had the capacity to hold the future planned winter coal output. The 
spring output could be stored outside, if necessary. ${ }^{207}$ That year, he prepared the foundations for a second hopper, above the first and twice as large. 208

Burrall's storage strategy immediately proved inadequate. Over the winter of 1908 , the winter crew mined 3000 tons of coal, below the anticipated amount. In defiance of Burrall's plans, Bert Mangham stored 1,800 tons of that in an exposed setting below the aerial tramway on a ridge overlooking the dock. Mangham only stored around 150 tons underground, likely because mining conditions did not allow for more.

Mangham improvised this temporary storage solution to keep the mine open and operational but in doing so invited more complications since Burrall now needed to find a way to transport the outdoor coal to the dock. Despite explicit attempts to avoid it, the outdoor storage approach was adopted and increasingly incorporated into the larger technical system through improved rail services, better outdoor location, mechanized storage and loading facilities and improved access to ships through adaptations to the dock. While company managers regularly complained that the coal storage system functioned inefficiently, the approach had immediate functionality and could be adapted and improved each summer. Alternatives took an extended time to implement, stalling or slowing the whole operation, and were costly. The company abandoned Burrall's plans for a second hopper.

207 Letter from Frederick Burrall to the Arctic Coal Company, July 25, 1908, Michigan Technological University Archives and Copper Country Historical Collections, Longyear Spitsbergen Collection (MS-031), box 4, folder 19.

208 Letter from Fredrick Burrall to the Arctic Coal company, December 10, 1908, in a letter from the Arctic Coal Company to Elihu Root, Secretary of State, December 31, 1908, "Arctic Coal Company. Coal Deposits in Spitzbergen.' U.S. National Archives II, Department of State Papers, M862 (3746), roll 342, from microfilm page 0144. 
In 1909, Coulson recommended the company improve coal loading by constructing a second dock. Despite Coulson's arguments that improved loading facilities were critical, the company rejected the plan. Coulson's proposal was costly and would take considerable time to construct. As with the coal storage facility, the company pursued adaptations to its existing coal handling facilities and expanded dock infrastructure, a less effective improvement but one that could be achieved more quickly and at less cost. Gibson again advocated for a second dock in 1911, perhaps attached to a second aerial tramway, and for coal storage bins that would better protect the coal and enable more efficient handling but again the company did not adopt these ideas. ${ }^{209}$

In 1912, Turner proposed much larger plans that would largely reinvent the coal storage system. During his tenure as General Manager, the company produced its largest amount of coal and he recognized that the natural bench that held the coal could not accommodate the predicted expansion. At first he argued that the company would need a modern and efficient overhead coal loading facility, but recognizing the great cost of such a facility he suggested a more modest change. In 1912, he and his assistants proposed to abandon the existing storage area for a much larger area on the beach to the north-east that to be serviced by a new aerial tramway connecting to the existing one. The system could distribute coal on the pile mechanically and efficiently take it to the dock when loading ships. As part of this project, Turner proposed building an entirely new powerhouse on the beach to provide a reliable service to the whole operation. $\mathrm{He}$

209 Letter from unknown (probably General Manager John Gibson) to J. M. Longyear, January 9, 1911, Longyear-Spitsbergen collection (MS-031), box 4, folder 24, and Letter from John Gibson to Scott Turner, December 21, 1911, Scott Turner Collection (MS-018), box CC, folder 09, both in the Michigan Technological University Archives and Copper Country Historical Collections. 
estimated it would take two summer seasons to complete the project. ${ }^{210}$ Longyear rejected this proposal, probably because he ultimately intended to sell the property and wanted to minimize capital expenditure, and instead Turner upgraded the existing storage and powerhouse, together taking only one summer season to complete.

In its earliest years, the Arctic Coal Company lacked a comprehensive plan to store its coal. While it considered a few possible solutions, it adopted an approach that it had explicitly rejected. Although inefficient, the approach worked and the company continued to enhance and expand it despite resistance to do so. Two primary reasons explain this pattern of development. Firstly, Ayer and Longyear showed discipline in their capital outlay. The above examples show that they regularly rejected viable but expensive proposals in favor of inefficient alternatives to keep costs within reasonable limits, in line with an exploratory style operation. The second factor is time. The limited construction time available in the Spitsbergen summer meant that large projects could take years to complete and slow the whole operation. As such, the company tended towards smaller, more achievable alternatives that allowed the system to continue to function with minimal delay.

\section{Non-Technical Aspects of the Organization}

When Longyear first considered the viability of mining on Spitsbergen, he looked at the quality and quantity of the coal, its close proximity to a good shipping harbor, the growing market for coal in Norway and the ability of the environment to support human habitation. Three non-technical complications not considered by Longyear and only

210 Arctic Coal Company General Manager's Report Covering Operations During the Year 1912-1913, Michigan Technological University Archives and Copper Country Collections, Longyear Spitsbergen Collection (MS-031), box 4, folder 13, 35. 
slowly recognized by the Arctic Coal Company proved to be amongst the most difficult problems to arise for building such a network: shipping coal to Norway, labor conflicts and the general expenses associated with managing a geographically isolated mining location.

\section{Commercial Shipping Issues}

Technical loading challenges facing the company were straightforward; it needed to load ships quickly over the summer months and did so by building three relatively independent coal loading systems. The larger implications of shipping on the network dawned slowly on the company as exports grew and efficient shipping became more critical.

From the outset, the company recognized that ships' summer leasing rates were significantly more expensive than other months due to demand but by 1910 General Manager John Gibson saw larger social and commercial complications. ${ }^{211}$ Norwegian skepticism of the enterprise's ability to meet contracts and deliver a quality product restrained the company's ability to make coal sales and alter shipping contract arrangements.

Gibson realized that the Arctic Coal Company competed with British coal companies for customers. British shipping firms regularly sent ore ships to Norway for iron ore and welcomed the chance to bring coal with them on the way. This meant that the British could profit from their ships moving in both directions while the Arctic Coal Company could only ever profit from one. Norwegian customers could expect regular and reliable

211 Letter, John Gibson Jr., General Manager of the Arctic Coal Company, to the Arctic Coal Company, November 5, 1910, Michigan Technological University Archives and Copper Country Historical Collections, Longyear Spitsbergen Collection (MS-031), box 4, folder 23. 
year round service with delivery guarantees from British coal companies and could negotiate smaller coal deliveries throughout the year. Gibson noted how this suited the bulk of Norwegian businesses that could not afford to take financial risks and or absorb large expenditures, and most companies' coal store yards were too small to hold a large delivery in any case. ${ }^{212}$

The commercial situation in Norway posed a serious problem for the company since, bound within a short summer shipping season, it preferred large, efficient single deliveries. The Norwegian commercial situation could force a ship to make several deliveries along the coast, slowed by the sluggish discharging technologies located at most Norwegian ports. Furthermore, Norwegian businesses remained skeptical of the company's ability to deliver and preferred to wait and see how it fared with other customers. The company's reliability remained a challenge as ships could face long delays waiting in line for the Spitsbergen loading dock to be free. The unreliable delivery time of single-trip ship charters to the company exacerbated the potential of loading delays. ${ }^{213}$

Gibson gave a great deal of attention to the matter of shipping over the winter months. He focused on spreading out the coal delivery times throughout the summer so that he could avoid hiring ships for single trips in preference for using them over the entire season and minimize bunching at the dock. He also attempted to arrange f.o.b. contracts, or 'free on board,' where the company delivered directly to customer's ships at Advent Bay. In 1911, Gibson reported continued skepticism by the Norwegian market about the quality of the coal and the ability of the company to deliver it reliably. Norwegian

212 Ibid.

213 Ibid. 
shipping firms also remained skeptical and refused f.o.b. rates, forcing the company to use expensive time charter rates. ${ }^{214}$

Scott Turner continued Gibson's approach and made considerable progress. Numerous enthusiastic accounts of the coal's qualities impressed the market and sales improved. Turner took particular pride in selling 1400 tons to the Norwegian Navy, whose opinion carried particular weight. ${ }^{215}$ While generally failing to attract f.o.b. shipping contracts, after 1913 Turner succeeded in contracting for ships at a flat rate per ton, which cost less and took some responsibility off the Arctic Coal Company. From that time forward, the company shipped the majority of its coal with flat-rate charters and with its own ship, the W. D. Munroe. The Arctic Coal Company even chartered the Kwasind from the Arctic Steamship Company each year under a competitive flat-rate contract.

Longyear had considered one approach to better connect with the Norwegian coal market and compete with British rivals since at least 1911. He worked with Turner on a proposal to form a new company to erect a coal storage depot on mainland Norway around Tromsø and perhaps one at or near Trondheim, which could discharge ships efficiently and accept large single deliveries from Spitsbergen. The company could then make smaller year-round deliveries, via rail or ship, to its Norwegian customers. ${ }^{216}$ The

214 Arctic Coal Company Annual Report for the year ending October 17, 1911, Michigan Technological University Archives and Copper Country Historical Collections, Longyear Spitsbergen Collection (MS-031), box 2, folder 3.

215 Letter to the Arctic Coal Company, probably from Scott Turner, General Manager of the Arctic Coal Company, April 5, 1912, Michigan Technological University Archives and Copper Country Historical Collections, Longyear Spitsbergen Collection (MS-031), box 5, folder 3.

216 Letter from the Arctic Coal Company to Mr. Lockard, Superintendant of the Quemahoning Coal Company, Ralphton, Somerset County, Pennsylvania, July 24, 1911, Michigan Technological University Archives and Copper Country Historical Collections, Longyear Spitsbergen Collection (MS-031), box 5, folder 1 and Dole, America in Spitsbergen, ii, 123-126. 
strategy appeared to be an ideal way to overcome many of the networks shipping problems. Turner received legal advice on the best way to achieve that aim and even prepared the draft paperwork needed to form a Norwegian joint stock company but never completed the project. ${ }^{217}$ By 1914, the Arctic Coal Company had attempted to avoid significant Norwegian government influence in their operations by removing or selling all holdings from the country, resulting in the depot project being stalled indefinitely. Turner also learnt that the Russian government was considering the construction of a trans-shipment port on Novaya Zemlya, an island off the north coast of west Russia. Turner wrote to the Russian Department of Commerce and Industry to express the company's interest in supplying coal to the facility or erecting their own coal storage facility there but the Russians did not pursue the offer. ${ }^{218}$

By the sale of the operations, the Arctic Coal Company had made significant progress in rationalizing its shipping arm into the network. It had built an inefficient but reasonably effective technical delivery system on Spitsbergen and had developed a good commercial reputation with Norwegian shipping firms and customers that allowed it to spread out its delivery dates and utilize better shipping contract terms. It had also identified a way to better connect with the small-scale Norwegian markets, although it did not pursue this option. Shipping costs remained very high, more per ton than the cost of mining coal, but stood roughly within the bounds of a profitable future mining company on Spitsbergen.

217 Letter from Scott Turner to Arnold Holmboe, April 29, 1912. Michigan Technological University Archives and Copper Country Historical Collections, Scott Turner Collection (MS-018), box CC, folder CCo9.

218 Letter from Scott Turner, General Manager of the Arctic Coal Company, to Assistant Minister Barck, Department of Commerce and Industry, St. Petersburg, Russia, February 22, 1912, Michigan Technological University Archives and Copper Country Historical Collections, Longyear Spitsbergen Collection (MS-031), box 5, folder 2. 


\section{Unskilled Scandinavian Labor}

At first, the company hired cheap Norwegian labor to carry out the company's heavy work duties. The arrangement was convenient for the workers, who received nearly double the pay for comparable work in Norway, ${ }^{219}$ and the company, who could not afford the high rates of skilled workers. Within a few years, it became clear that labor had systemic characteristics that threatened the integrity of the entire network, and required careful consideration. A strike could halt the operation and bring great expense while ethnic conflicts could lead to violence and destabilization. Poor labor relations and policy could promote inefficient work, which would be a drag on the whole operations regardless of its technical sophistication. Lacking a simple solution, the company approached the problem on several levels and made reasonable progress with it.

Isolated from the rest of the world and working with almost no legal protection, the company had little protection from strikes, illegal activities or outbreaks of violence. This became quickly evident when the workers struck for a week in the summer of 1906, with no gains. ${ }^{220}$ Workers declared a major strike in 1912 and threatened another in 1913, both of which were resolved with no gains and large portions of the workforce were shipped home. Above all, the threat of a labor strike involving shipping presented the most serious concern. Turner described it thus:

"A strike of the loading crew during the shipping season is the thing most to be feared. A temporary shut-down of the mine, or a cessation of outside building and construction work would be bad, but not ruinous; but if the

219 Fletcher, Alfred C. B., "From Job to Job Around the World. The Adventures of Two Wanderers." The Wide World Magazine. Installment IX (1912) Michigan Technological University Archives and Copper Country Historical Collections, Scott Turner Collection, box Z, folder Z3O.

220 Letter from William Munroe to the Arctic Coal Company, July 13, 1906, Statsarkivet i Tromsø, Arctic Coal Company Collection (Privatarkiv nr. 101), box 91, folder '1903 - 1907 M.' 
loading crew, consisting at present of about 50 men, cares to do so, it can tie us up completely. Such a strike ... would be catastrophic.” ${ }_{221}$

To counter potential strikes, the company considered hiring its own police force but shied away from doing so because it thought workers would react against one. ${ }^{222}$ It also strongly pushed the formal legal recognition of the archipelago with terms for police and guardians of the peace. In one proposal, it suggested it would contribute $\$ 2500$ annually to affect that but no such terms ever came into effect during the company's existence. The company recognized that it had no capacity to stop the threat of strikes but could lessen it by trying to treat its workforce well and by choosing men wisely.

In describing the labor relations at Longyear City, Ole Vatten divides the Actic Coal Company period into two phases: one of relative harmony in the earlier years and one of conflict between employees and management. ${ }^{223}$ Vatten attributes the conflict to Spitsbergen's isolation, difficult climate and lack of laws, cultural differences between American management and Scandinavian employees, and the minimal effort related to worker health, although notes that worker action was fractious and not reflective of union activity. Dag Avango disputes this last point, citing the mass quitting of the workforce in 1912 and 1913 as a typical strategy of the union movement called "Söning." ${ }^{224}$ Another indication is that the workers used the unionist slogan "direkt

221 Arctic Coal Company General Managers Report for the year from Oct.1 1912 to Aug 31,1913, Michigan Technological University Archives and Copper Country Historical Collections, Longyear Spitsbergen Collection (MS-031), box 4, folder 13.

222 Letter from Scott Turner to J. M. Longyear, May 24, 1913, Michigan Technological University Archives and Copper Country Historical Collections, Longyear Spitsbergen Collection (MS-031), box 5 , folder 5 .

223 Vatten, Longyearbyen 1905-1935, 146-148.

224 Avango, Sveagruvan: Svensk Gruvhantering Mellan Industri, Diplomati Och Geovetenskap, 212. 
aksjon" (“direct action” in English.) The movement was then rapidly growing in Scandinavia at this time, especially among the groups of workers that came to Longyear City: construction workers, laborers and miners. This union movement quickly establishment established itself in Longyear City under the Store Norske Spitsbergen Kulkompani.

The Arctic Coal Company needed to offer generous terms to attract the workforce it needed to this isolated, difficult region. Cost ruled out the use of a predominantly British workforce and pushed the company to use predominantly untrained Norwegians, mostly farmers and fishermen, who they paid around double comparable Norwegian wages (5 Kroner per day for laborers and 6 for miners.) ${ }^{225}$ This brought its own difficulties. The vast majority of its Scandinavian workforce had no skills in coal mining, needed training and proved to be inefficient. Many disliked the work and quickly quit their positions and many never returned to the company.

The company used numerous strategies to promote efficient work. In late-1908, it installed the contract system for working in the mine, thus placing some responsibility for earnings on the miners. ${ }^{226}$ It also promoted a bonus for miners reaching a specified output in one month. The company was immediately satisfied to find its miners working longer and harder, at times doubling their output from previous levels, although no

225 Christian Science Monitor, December 10, 1913, Arctic Coal Yield to be increased, Michigan Technological University Archives and Copper Country Historical Collections, Longyear Spitsbergen Collection (MS-031), box 4, folder 10.

226 Arctic Coal Company Annual Report for the year ending October 15, 1909, Michigan Technological University Archives and Copper Country Historical Collections, Longyear Spitsbergen Collection (MS-031), box 1, folder 13. 
worker ever made the bonus. ${ }^{227}$ The company later worked both the aerial tramway and branch tramway under contract, finding similar success.

By mechanizing its operations, the company reduced its reliance on unskilled workers. It also encouraged better workers and a less transient workforce by attempting to develop a good reputation of its treatment of men with good housing, good food and safe conditions. Alternately, should the mine gain the reputation of being unsafe, or a mining disaster occur, the company's abilities to attract good men would be severely diminished. The company had few deaths and injuries but constant negative Norwegian press accounts damaged its reputation regardless. While the company hoped safe conditions would encourage good workers to stay, it used blacklisting both as a way to avoid rehiring poor workers and a threat to keep workers in line. From as early as 1908, the Arctic Coal Company kept records of 'undesirable' workers and those it judged worthy of rehiring, even using Spitzbergen Coal and Trading Company blacklists to help it. Turner later expanded the scheme with a card system for worker records. ${ }^{228}$

Turner also paid close attention to the ethnicity of his workforce as he perceived in them different attitudes to work, the company, and to other cultures at the operations. On his assumption of the position of General Manager, he looked at ways of reducing the use of Norwegians, who he saw as too inefficient and too socialistically minded. In 1912 he experimented with a larger Finnish workforce but believed them to be dangerous as well

227 Letter from Jno. Gibson, Jr., General Manager of the Arctic Coal Company to the Arctic Coal Company, June 3, 1910, Michigan Technological University Archives and Copper Country Historical Collections, Longyear Spitsbergen Collection (MS-031), box 4, folder 22.

228 Spitzbergen Coal and Trading Company blacklists, Statsarkivet i Tromsø, Arctic Coal Company Collection (Privatarkiv Nr. 101), box 113, folder '1906 - 1909 Useful Memos B.' 
as inefficient. ${ }^{229}$ That winter he experimented with a larger skilled British workforce with a view of an even larger one the next summer but found them at least as much trouble as the Scandinavians. ${ }^{230}$ By 1913 both he and Longyear began to consider ridding themselves entirely of Scandinavians by bringing a permanent workforce from China ${ }^{231}$ and Longyear proposed only using American, Canadian of Scottish workers ${ }^{232}$ but they never pursued either plan. Finding little in improving the network in this way, Turner returned to the original spread of nationalities and worked with what he had.

Turner introduced better labor hiring policies that helped improve the workforce. From 1913 the company focused on selecting good foremen and then asking them to choose their own workers. The foremen, held responsible for their decisions, tended to choose better quality workers to work below them. That same year, Turner began to seek Norwegian farmers from outlying districts, who he found had less connection with Norwegian labor organizations and he thought would cause less trouble. In both actions, Turner attempted to diminish the threat of labor resistance against the dislocation of the network. The foreman strategy introduced a greater labor hierarchy that gave management more power over its labor force and broke up the workforce into smaller, more manageable units.

\footnotetext{
229 Letter from Scott Turner, General Manager of the Arctic Coal Company, to the Arctic Coal Company, June 21, 1912, Michigan Technological University Archives and Copper Country Historical Collections, Longyear Spitsbergen Collection (MS-031), box 5, folder 4.

230 Letter from Scott Turner to J. M. Longyear, May 24, 1913, Michigan Technological University Archives and Copper Country Historical Collections, Longyear Spitsbergen Collection (MS-031), box 5 , folder 5 .

231 Ibid.

232 Ibid.
} 
These and other efforts, including the company's housing strategy, did little to promote a quality, stable workforce until the last year of operations as the company routinely blacklisted a third or more of its workers, listed another third as 'no good,' and only looked to the remainder as a potential longer term workforce, the majority of which were not interested in a second season. ${ }^{233}$ The Arctic Coal Company always regarded its regular workforce as inefficient and posing the treat of strike or violence. Its adoption of several labor strategies including the use of contract work, changes in how workers were selected and building a reputation for good, safe work practices, helped bring about partial workforce stabilization in later years. Scott Turner recorded that the majority of workers employed over the winter of 1914 - 1915 had already worked for the Arctic Coal Company and were hand picked for the season, bringing the best results in the company's history. ${ }^{234}$

\section{General Expense Account}

The final major non-technical factor of the organization was the archipelago's isolation which made some aspects of the operations very expensive. By 1914, improved accounting systems allowed Turner to isolate this cost category from other production costs and he found that the costs in the general expense account would prevent the company from ever profiting from mining on Spitsbergen.

233 Arctic Coal Company General Managers Report for the year from Oct.1 1912 to Aug 31,1913, Michigan Technological University Archives and Copper Country Historical Collections, Longyear Spitsbergen Collection (MS-031), box 4, folder 13.

234 Arctic Coal Company General Managers Report Covering Operations During the Fiscal Year June 1, 1914 to may 31, 1915, Michigan Technological University Archives and Copper Country Historical Collections, Scott Turner Collection (MS-018), box Z, folder Zo3 
Turner argued that typical American mining companies should seek a general expense account of less than $5 \%$ of the total production costs. The Arctic Coal Company's account stood at $37 \%$. Most of this expense, he argued, related to the isolation of Spitsbergen. The company used three offices, one each in Boston, Tromsø and Spitsbergen and paid high management costs to hire men and manage ships. The cost of simply shipping Americans to and from the site was itself considerable. By having to look after its workforce, it spent heavily on housing, food and medical care. Legal expenses to protect Ayer and Longyear's claims and promote the interests of the company alone reached 10\% of general expenses. As the company had little opportunity to lower these costs, it could never hope to profit from mining at this scale on Spitsbergen, in Turner's opinion. ${ }^{235}$

\section{Spitsbergen's Arctic Environment}

This chapter drew out several aspects of the role of the Arctic environment on the Arctic Coal Company's network. To be clear on the full implications of that actant, the role of the Arctic is considered in isolation here. As described above, in 1903 Longyear favorably considered Spitsbergen's Arctic environment in terms of its ability to allow shipping and permanent human habitation, coal and market. This chapter has shown that while Longyear's estimation proved correct, the Arctic proved to be a powerful force on development in ways that he had not anticipated.

The Arctic Coal Company and its visitors regularly agreed that Spitsbergen's weather did not greatly hinder the operations. The temperature inside the mine remained at around

235 Arctic Coal Company Annual Report for the year from September 1, 1913 to May 31, 1914, Michigan Technological University Archives and Copper Country Historical Collections, Longyear Spitsbergen Collection (MS-031), box 4, folder 15, 26. 
$27^{\circ} \mathrm{F}$ degrees, a reasonably comfortable temperature for hard work, ${ }^{236}$ and outdoor temperatures, while variable, generally stayed within tolerable levels. Certainly, Arctic storms, high winds, cold spells and ice flows did disrupt outdoor work and challenge shipping, but the company must have anticipated these types of events from the outset. The very late summer of 1915, which kept waterways closed until early July, reminded the company that the Arctic was not tame. For the most part, though, episodes like these were uncommon.

The two major obstacles related with Spitsbergen's Arctic location was its summer / winter cycle and its geographic distance from densely settled areas. The cycle had a profound influence on the way the company developed from its inception. The short summer construction season pushed the management to adopt simple infrastructure solutions that it could achieve over one summer rather than more complex solutions that would take more time. This in turn promoted the evolutionary development approach seen in the growth of the company's technical system.

The summer / winter cycle drew out numerous technical, economic, political and social complications that the company struggled to meet while its English competitors, free of this, had fewer problems. The Arctic Coal Company responded to many of these complications by expanding the operations with new and better facilities. It invested extensive time and capital into the coal storage and delivery section of its operations to allow it to store all coal mined over the winter, load it quickly onto ships and meet customer's expectations on timing and delivery size, against the backdrop of strong English competition. The company also purchased two ships to better control shipping

236 Hoel, Adolf, c.1916, The Arctic Coal Company's Coal Fields on Spitzbergen, translation, Michigan Technological University Archives and Copper Country Historical Collections, Longyear Spitsbergen Collection (MS-031), box 2, folder 23. 
and reduce delivery costs, and considered establishing coal storage depots in Norway and Russia to deliver coal more efficiently to customers.

Spitsbergen's geographic isolation added significantly to the costs of managing and operating the enterprise, largely visible in inflated general expenses. Discussed above, general expense expenditure stood at an unsustainable level that prevented the company any chance of profiting from mining on Spitsbergen. Beyond this, the company needed to pay its non-managerial workforce around twice as much as they would have received at home, and faced increased shipping costs. The isolation also slowed the delivery of goods to the site that at times were desperately needed.

The climate forced the company to rethink some of its approaches to construction. Winter ice flows forced the Arctic Coal Company to alter the dock from a pile to filled design. ${ }^{237}$ Shifting soils of the active layer resulted in the sinking of the powerhouse foundations, forcing ongoing temporary repairs and changes to foundation design for the 1913 powerhouse addition. Examples of such problems are limited and in most ways the company found success with standard technologies and construction approaches. It also interrupted a reliable pattern of work as employees using the first ship of the season often had to travel up to 30 miles over ice between Longyear City and the ship, often transporting goods and equipment with them. ${ }^{238}$

237 Arctic Coal Company Annual Report for the year ending October 15, 1909, Michigan Technological University Archives and Copper Country Historical Collections, Longyear Spitsbergen Collection (MS-031), box 1, folder 13.

238 Ibid. The Arctic Coal Company's first ship to Spitsbergen often got stuck in ice between the mouth of the Ice Fjord and its camp at Green Harbor, necessitating the slow transfer of men and equipment between camps over the ice. 
Spistbergen's Arctic environmental conditions also offered opportunities that the company quickly drew into its network. The warm waters of the Gulf Stream opened the shipping lanes each summer to company ships, although ice flows coming from the eastern archipelago could block fjord entrances in a way that the company found hard to predict. The company used local topography to shelter its mine from moving soils and falling debris. That the mine and coal hopper remain on the landscape today is a testimony to the value of that shelter. Finally, the company utilized the snow fall around Longyear City to provide fresh water necessary for equipment and the workers.

\section{The Operation as both System and Collection of Individual Parts}

The Arctic Coal Company's mining experts routinely predicted that the company had the capacity in the future to produce and sell from 110,000 to 200,000 tons of coal annually, yet the largest amount produced was 44,090. ${ }^{239}$ The company's complete but inefficient technical system helps to account for part of the output discrepancy, as does the use of unskilled Scandinavian labor. This system view obscures another equally important observation: that many individual components required considerable efforts to function with the network in the first place. This drew both attention and manpower away from the core function of the operations since the company needed to work on two levels: one that managed the whole system and one that labored to make individual components work together.

The company's powerhouse provides an ideal case study to explain the company's dual focus. Built over 1909-1910, the powerhouse provided an unreliable service, mostly

239 Arctic Coal Company General Managers Report Covering Operations During the Fiscal Year June 1, 1914 to May 31, 1915, Michigan Technological University Archives and Copper Country Collections, Scott Turner Collection (MS-018), box Z, folder Zo3. 
caused by human error. Burrall failed to compensate for Spitsbergen's Arctic soils and the foundations failed and sank. This caused serious difficulties with the machinery inside that then needed regular maintenance and adjustment to function. Poor choices of machinery also led to regular breakdowns. Turner's 1913 extension with new equipment provided a reliable but insufficient power supply. ${ }^{240}$ On the systems level, the company needed to work around an unreliable and inadequate power supply. On the individual component level, the company extended tremendous effort to get the facility to even operate. By Turner's tenure, the company needed to jack up the original foundations and realign machinery bi-annually. The company failed to develop a regular supply of water and for much of the year a team of men hauled water to the plant. The company also needed to regularly send for replacement parts, monitor and perform maintenance to its machinery. ${ }^{241}$

The dynamic holds for many other parts of the operations. The company's first coal loading crane, known as the Hayward Crane, regularly broke down and required regular repair simply to function. ${ }^{242}$ Both ships, the W. D. Munroe and the Kwasind, needed regular maintenance and several major overhauls to recover from the damage associated with shipping in icy Arctic waters. Goods stored in the warehouses froze together over the winter, requiring excavation each summer. The Scandinavian workforce required training at the beginning of each summer or winter period to simply accomplish the tasks at hand.

240 Hartnell, Cameron, et al., 'Arctic Coal Company Powerhouse.' 241 Ibid.

242 Arctic Coal Company General Manager's Report for the year 1911-1912, Michigan Technological University Archives and Copper Country Collections, Scott Turner Collection (MS018), box Z, folder Z13. 
The pressures to hold the organization together and move forward sat heavily on the management. Turner privately remarked that "There is a world of work to be done, and I never was so busy in my life ... I doubt if there is a job anywhere connected with mining that has as many diversified phases of business connected with it as this one." 243 His staff took the burden too, often working extended workdays, every day of the week. ${ }^{244}$

\section{Conclusions}

Much of the Arctic Coal Company's work on Spitsbergen was typical for the mining industry. The company's actions on the landscape show that it followed a common strategy to mine development that improved its chances to mine a good seam, allowed it to start operations quickly while resisting investment on other important infrastructure until the owners had confidence in the mine's potential. In order to function while still small, the company used its simple system flexibly and slowly moved towards single-use equipment to operate more efficiently and predictably.

The company successfully installed and used standard coal mining and industrial infrastructure without the need for equipment specialized for the cold climate. They also successfully implemented mining and operational practices that were common to the coal mining areas of America and Britain. The Arctic environment did little to discourage the use of standard technologies and in only a few cases did the infrastructure fail, such

243 Letter from Scott Turner to Wilber Judson, April 16, 1912. Michigan Technological University Archives and Copper Country Collections, Scott Turner Collection (MS-018), box A, folder A22.

244 Fletcher, Alfred C. B., "From Job to Job Around the World. The Adventures of Two Wanderers." The Wide World Magazine. Installment IX (1912), Michigan Technological University Archives and Copper Country Historical Collections, Scott Turner Collection (MS-018), box Z, folder Z30. 
as the dock and the powerhouse foundation which required some adaptation to meet local conditions.

In contrast, the environmental features of climate and geographic isolation impacted the function of the whole system by undermining the integrity of the network. The Arctic climate forced the company to work on a summer/winter cycle where it performed most construction work and delivered coal over the summer months while focusing on mining over the long winter. While the mine itself functioned reasonably well, the cycle presented serious problems for connecting the mine with the broader commercial realities of the region. At first management adopted physical solutions by expanding the outdoor storage facility and augmenting coal loading capacity to load ships more quickly and deliver the winter output over the short summer. Faced with a short construction season, the company chose solutions that could be enacted quickly, which resulted in them continually adapting and improving the existing system rather than overhauling it. Recognizing the limited scale and technological sophistication of Norwegian ports and their clients' preference for small deliveries of coal, the company spread deliveries across the summer to decrease shipping bottlenecks and improve the reliability of delivery times. Longyear also considered constructing at least one coal depot in Norway or Russia that would allow the company to efficiently ship larger quantities of coal from Spitsbergen and make smaller deliveries to clients year round, but did not pursue the idea.

By the later years, company management was reasonably satisfied with its efforts to rationalize the Arctic climate into the network but in expanding the operations to do so, they delayed completing the exploratory development phase and, perhaps, the sale of the company. Spitsbergen's isolation proved to be a strong dislocating force on the network 
that the management made almost no headway in rationalizing. Its distance from settled regions added to all transportation costs and forced the company to house its entire workforce. Spitsbergen's political isolation, evident in its terra nullius status, necessitated the use of expensive legal and diplomatic representation. Ultimately these costs were too high for the company to have any chance at profiting from their mine.

The potential for labor resistance presented a serious threat to the network that the company only made limited progress in overcoming. The network had a particular vulnerability at the coal loading operations because it sat at the intersection of two major dislocating actants: shipping and labor. The company attempted to encourage the enlistment of good workers on an ongoing basis by gaining a reputation of providing a safe, comfortable working environment, which bad press in Norwegian newspapers blemished although the company did see signs of progress in later years. Turner's strategy to rely on foremen to hire and manage their own teams helped to strengthen management's control over the workforce and break into more manageable groups. Turner experimented with labor from different nations but ultimately returned to a predominantly Norwegian workforce. His strategy to seek out Norwegian agricultural workers, which he judged had less connection with the labor movement, may also have helped diminish the threat of labor resistance. By the close of business, though, labor costs remained high and the labor threat real. 


\section{CHAPTER 5}

\section{The Expansion of Longyear City}

\section{Introduction}

The settlement of Longyear City was an essential component of the Arctic Coal Company's network as it provided living space for the workers who built and operated the company's technical system. Isolated from the rest of the world and from any other significant settlement, the company needed to provide housing for all its workers to accomplish its commercial goals. The provision of houses, though, proved to be a difficult balancing act. Housing construction took from the limited pools of capital, labor and material resources that the company also needed for its core operations. Spitsbergen's isolation and climate made company housing a greater burden than for most American companies because it made material costs higher, design requirements greater and the construction season much shorter. The outcomes are important as they impacted the class of worker attracted and the permanence of the workforce. The character of Longyear City, then, represents much more than simple decisions on capital outlay made by management. It represents a struggle to balance different organizational needs with limited resources in a difficult environment.

Analysis considers this critical component of the Arctic Coal Company's operations by following the expansion of the town to understand how the settlement was designed and why it was developed as it was. As with earlier chapters, it identifies the problems that the company management faced and their strategy to use the settlement as a way to overcome them. Comparison with contemporary American, Swedish and British 
company towns indicates how the town related with larger trends in company housing and isolates facets that are unusual and typical in Longyear City.

\section{Methods}

The changing material manifestation of Longyear City forms the basis for analysis of the Arctic Coal Company's housing strategy, its implications for the workforce and larger network. Three plan drawings adjoin the discussion of the periods that show Longyear City at the end of each time frame, in 1908, 1911 and 1915. Similar to the wharfing and storage area, only two company maps depict the town, from 1912 and 1913 and documentary, photographic, and archaeological evidence was used to reconstruct its yearly status. ${ }^{245}$ For accuracy, the maps provided here adopt the spatial layout of the Arctic Coal Company's 1913 map and the topographic contours on both the 1912 and 1913 maps, leaving out privies, power lines and telephone lines as they would distract from the core message of the chapter.

Company records include minimal discussion on the company's broad strategy towards its settlement, the bulk being proposals for and confirmation of the construction of new structures with almost no discussion of town planning. Analysis of the size, internal layout and space per worker for accommodations brings insights into the living conditions and social hierarchy of the town and details a facet that is readily comparable with other designed industrial mining settlements in the US.

2451912 USGS map by Thomas H. Moncure, Michigan Technological University Archives and Copper Country Collection, Keweenaw Digital Archives, MSo18-Z-27-01 and 1913 Arctic Coal Company plan of Longyear City, plan \#96, Michigan Technological University Archives and Copper Country Historical Collections, Keweenaw Digital Archives, MSo18-Z-09-03. 
This project takes a simple method towards calculating this floor space ratio: it calculates the floor-space of the entire structure and divides that by the number of workers the company intended the structure to house. For Longyear City, this method works well because of the simplicity of accommodation structures the company constructed, yet this requires some further explanation. The calculations include the accommodations associated with the core mining activities surrounding Mine 1, including those in Longyear City proper northwards to the wharfing and storage area and one hut at nearby Mine 2. It excludes a hunter's hut located in Advent Valley, a hut intended for the nearby Flower Valley, now Blomsterdalen, and all other accommodations at Coals Bay and on the three 'Ayer \& Longyear' land claims.

The calculation uses a structure's intended number of inhabitants, not the number that actually used them. The difference is critical because while the Arctic Coal Company planned towards certain outcomes, it regularly adapted its plans to meet immediate requirements. It used numerous structures for storage, rather than accommodations, and used buildings like the boarding houses in different ways than intended. Furthermore, archival research uncovered little detail on the use of each structure yearby-year, making a calculation based on actual use problematic. For a few structures, the record lacks data on the number of inhabitants, intended or otherwise.

Arctic Coal Company records state the size of most, but not all, of the structures constructed. For those not detailed, this study used the findings of a 2004 archaeological survey of Longyear City and parts of Spitsbergen's Ice Fjord by representatives of the Michigan Technological University with an international team of researchers within the 
LASHIPA project. ${ }^{246}$ The author measured the remaining structures from a 1913 scale plan of Longyear City. ${ }^{247}$ The latter two methods produced a reasonably accurate floorspace measurement, suitable for the purposes intended by this work. In the case of the mess/barrack, labeled number 1 on the three town plans, the study subtracts the estimated mess space from the floor-space calculation. For historical consistency, the chapter uses the names for buildings given by the Arctic Coal Company. Where the company used two or more names, the author has chosen the one that indicates identity most clearly. Readers should note that the company's use of 'bunkhouse' and 'barrack' does not necessarily indicate different types of buildings and should rely on the author's descriptions to understand each building's layout and use.

\section{The Evolution of Longyear City}

\section{Phase 1 (1905 - 1908): The Establishment of Longyear City}

In the earliest years, the Arctic Coal Company fixed its attention on understanding the basic elements of the local coal landscape around Advent Bay and then making fundamental decisions on where to base its operations. The settlement location remained temporary until management decided on a permanent site for it. Even then, the company was slow in bringing together the basic elements of a mining settlement in favor of concentrating on mining infrastructure construction.

246 Martin et al., Industrial Heritage in the Arctic and archaeological records kept at the Michigan Technological University, Social Sciences Department.

2471913 Arctic Coal Company plan of Longyear City, plan \#96, Michigan Technological University Archives and Copper Country Historical Collections, Keweenaw Digital Archives, MSo18-Z-09-03. 
The records and photographs of the early years present a fragmented view of the company's original settlement. While photographs show the types of accommodations used, the study has not uncovered information on the distribution of goods and workers within them.

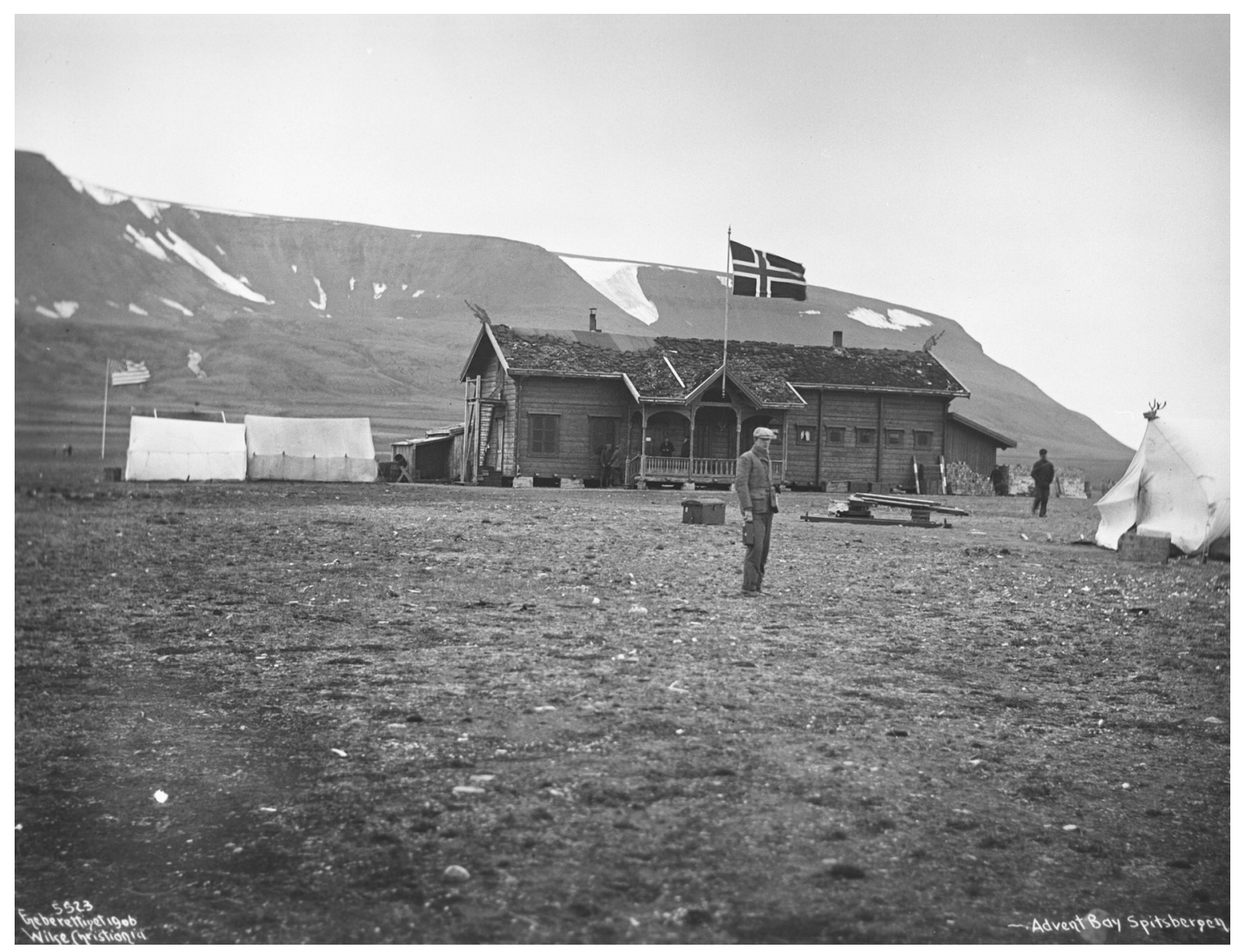

Figure 5.1 1906 photograph of the original temporary settlement area on Advent Point, Advent Bay, by Anders Beer Wilse. Part of the Arctic Coal Company's 1 1/2 story house is partly visible behind a tent on the left, adjacent an American flag. Used with permission from Norsk Folkemuseum, Wilse Collection, number 9404-04109. Permission letter included in Appendix B. In 1905, William Munroe based the earliest settlement around a disused tourist hotel on Advent Point that a Norwegian company had built in 1896, which he leased from the Trondhjem-Spitsbergen Kulkompagni and bought from them the next year. Figure 4.1 
shows the location of this original temporary settlement. ${ }^{248}$ The company used at least part of the hotel as a barrack. Men not sleeping there may have used tents or slept on board the company ship, anchored in the bay. In 1905, pressed for building materials, the company sent a party to an abandoned mining and scientific station on nearby Cape Thordsen, known as the Nordenskjold Camp, on the east side of the Ice Fjord, and took three walls of a house and scrap iron back for use on Advent Bay. ${ }^{249}$ Photographs from 1906 by the renowned photographer, Anders Beer Wilse, show a short, temporary wooden dock servicing Advent Point, three canvas tents, a shed and a 1 1/2 story wooden house. ${ }^{250}$ An inhabitant of that house over the summers of 1906 and 1907 later stated that it was a "portable house which was to be the home of the manager, his wife, and myself as their guest.” ${ }_{251}$

The Advent Bay camp provided only the most basic facilities. A minimum extent of building types grouped workers together in simple accommodations and with better lodgings for management and their guests. The buildings probably provided space for the storage of some items while more goods, such as timber, remained exposed outside.

In July 13, 1906, William Munroe wrote the company office in Boston to say that he had begun building mining facilities in Longyear Valley and that he would soon lay a simple

248 Dole, America in Spitsbergen, i, 322.

249 Letter from Frederick Burrall, General Manager for the Arctic Coal Company, to Herbert H. D. Peirce, United States Minister to Norway, March 19, 1909, Michigan Technological University Archives and Copper Country Historical Collections, Longyear Spitsbergen Collection (MS-031), box 4, folder 20.

250 Photograph taken by Anders Beer Wilse in 1906. Norsk Folkemuseum, photograph no. 940404109 .

251 Brigham, Louise, Box Furniture: How to Make a hundred Useful Articles for the Home. (New York: The Century Co., 1910), preface. 
rail line from Advent Bay to below the mine, where he would begin to build houses. ${ }^{252}$ At first he concentrated on the company's most pressing needs by constructing four small barracks to house its men, a mess to feed them, a few structures to hold the company's animals and one or two buildings for storage. The building stock of 1907 in this location lacked any office or house for management, which may have continued on in the buildings on Advent Point some distance away. In 1908, with the completion of a staff house that served as the office, quarters and eating place for upper management, and the moving of the old hotel into town, the company succeeded in assembling the basic facilities of a mining settlement. Figure 5.4 shows the town layout in 1908. From this time forward, the old hotel, later known as warehouse \#3 and visible second from the right in the figure, served as the company store and warehouse.

Munroe's choice of location related much more to local environmental conditions than technical or social ones, suggesting his desire for a quick and easy approach to development. Rather than locate directly below the mine, around the rail incline, he located around 900' north-east. This location offered the flattest land in the vicinity, making it easier to build with minimal alterations to the environment. The location was about as far north as possible while still remaining sheltered from westerly winds by an adjacent ridge. While the buildings roughly follow the same axis, they do not follow the same alignment and align to the contours of the local topography, which presumably enabled easier construction.

252 Munroe to the Arctic Coal Company, July 13, 1906. Statsarkivet i Tromsø, Arctic Coal Company Collection (Privatarkiv Nr. 101), box 91, folder '1903 - 1907 M.' 


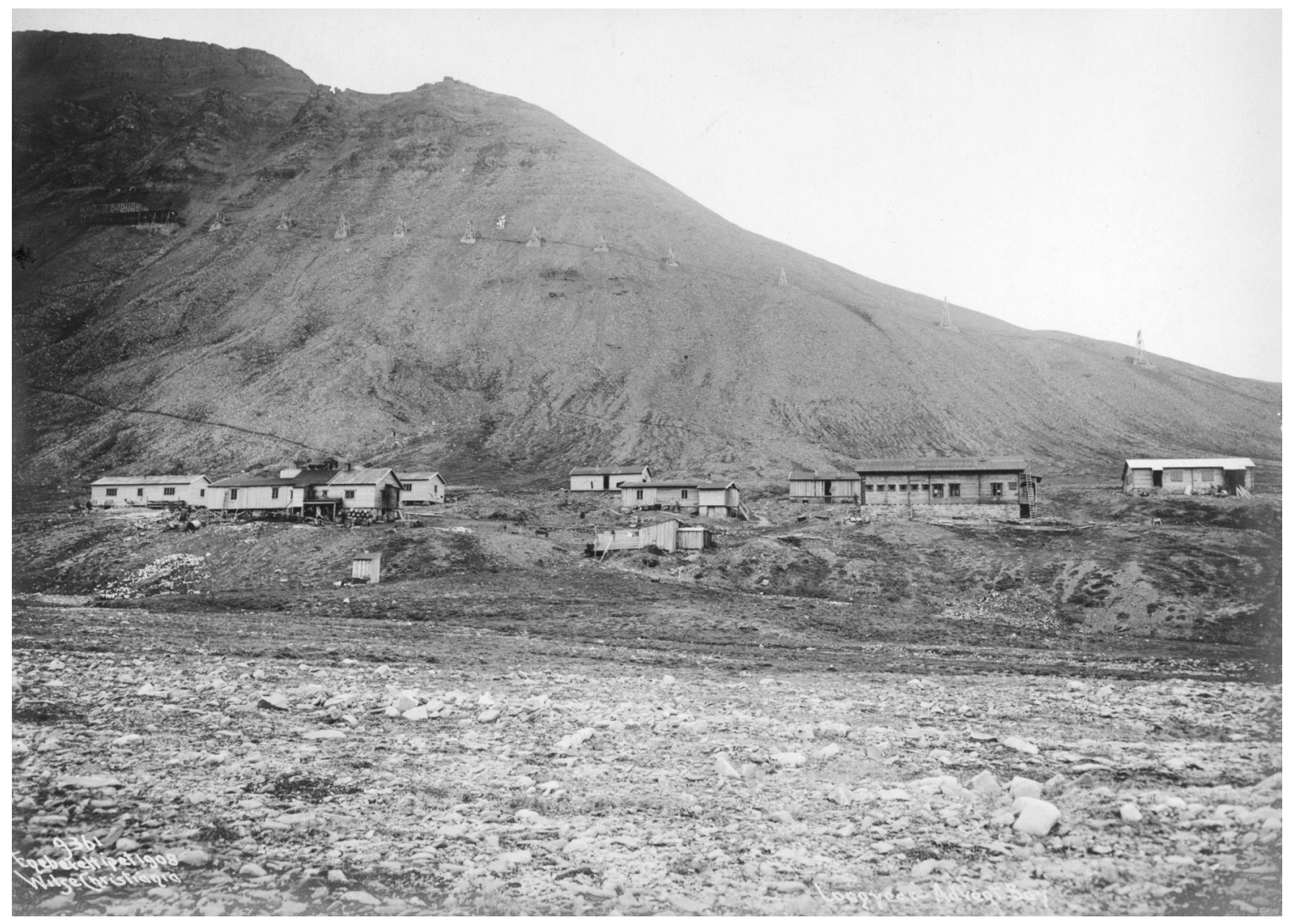

Figure 5.2 Photograph of Longyear City in 1908 by Anders Beer Wilse. The first phase of the city featured simple wooden gable buildings located on the flattest area near the mine and adjacent the Longyear River drainage. Mine 1 is partly visible top-left. Michigan Technological University Archives and Copper Country Collections, Michigan Technological University, Keweenaw Digital Archives, MSo31-01-01-19. 


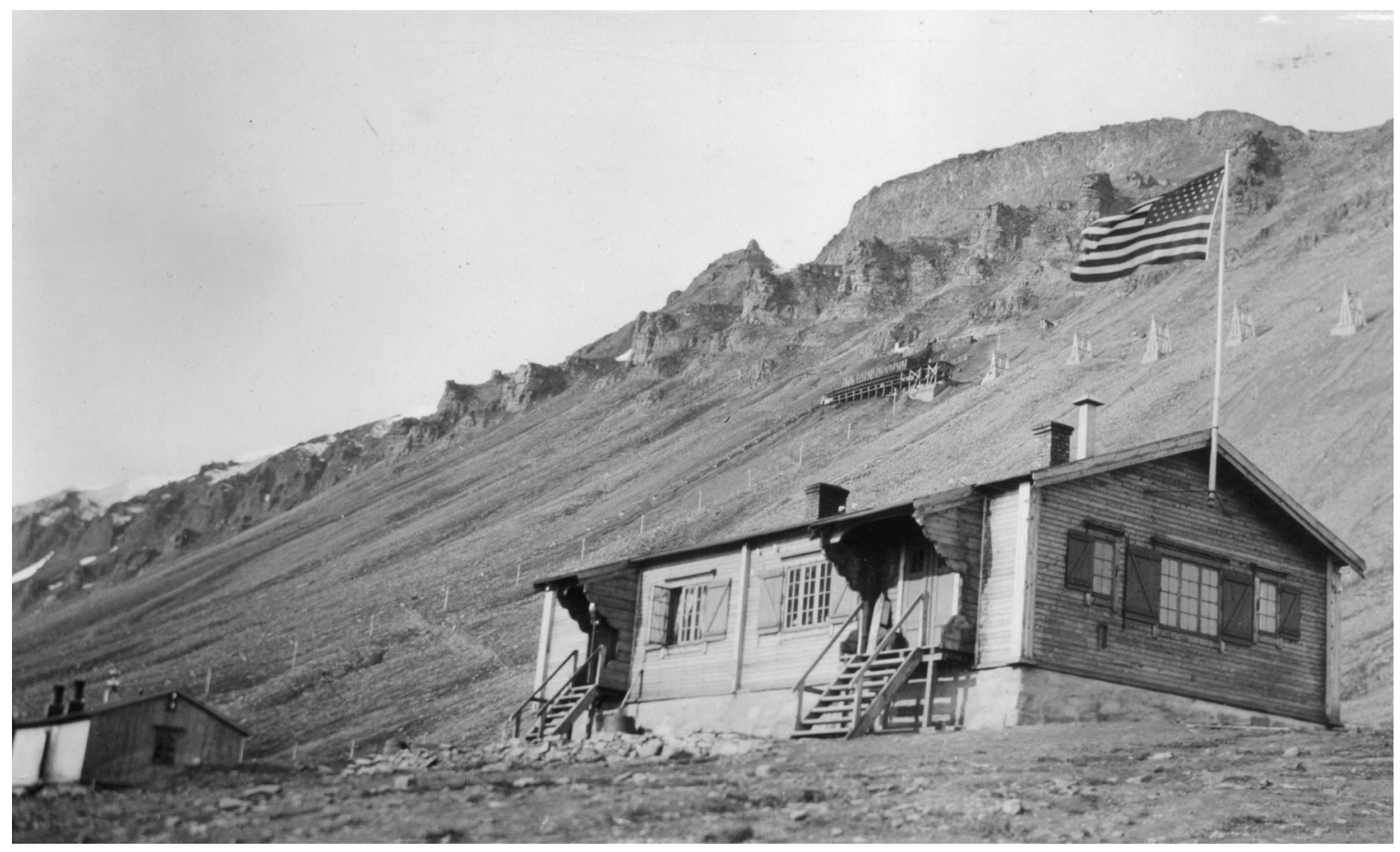

Figure 5.3 The Arctic Coal Company staff house announced the settlement to visitors. It was the most decorative building the company ever built. Its minor decorative features stand in contrast to a storage shed at the left of the photograph. Mine 1 is visible on the slopes behind the staff house. 1913 photograph by unknown photographer. Michigan Technological University Archives and Copper Country Historical Collections, Michigan Technological University, Keweenaw Digital Archives, MSo18-007-01-04.

Figure 5.4 shows the company used the simplest layout method available to them: they simply grouped buildings together with little effort in projecting a social hierarchy or starting a formal town plan. The town had no roads, only paths created by the common movements of people. The railroad bed probably served as the major walking route out of town. The layout shows some basic design ideas. Buildings most associated with waste, including the barn, the shed and the mess hall as well as at least one privy, lay on the lower slopes below the rail line and near an adjacent slope over the Longyear Valley drainage. The company disposed of most of its waste into the drainage, away from the rest of the camp. The buildings in two rows above the rail line have entry doors facing 
one another, creating a vague social space and corridor. The company later enhanced and expanded on this corridor, making it the main route through Longyear City. The staff house, pictured in Figure 5.3, presents the only semblance of social hierarchy in terms of layout position. As the most northern building, it announced the city to visitors with a large American flag flying above. This is also the only building to which the Arctic Coal Company ever added decoration, with two wooden awninged entrances.

All buildings at Longyear City at this time featured wooden construction. The company used prefabricated or semi-prefabricated buildings and paid Norwegian lumber companies, usually in Trondheim, to cut and dress the timber needed. The timber framework of warehouse \#4, still standing in the wharfing and storage, still has identification marks from its pre-fabrication in Norway that allowed it to be rapidly reerected on Spitsbergen. ${ }^{253}$ All company constructed buildings had a balloon frame design, as was common in the US, with a simple gable roof and little to no decoration to allowing for cheap and quick erection. Initially, the only real accommodation to the Spitsbergen climate was the installation of double windows to keep in the heat; from 1908 the company may also have double sheathed its housing. ${ }^{254}$ The company did not install basements for any structure and instead placed them above ground with minimal excavation into the soil for foundations, made of local stone.

\footnotetext{
253 Hartnell, Cameron and Seth DePasqual, ACC Warehouse \# 4, Feature o.19, Unpublished Inventory Sheet (Houghon, MI: Michigan Technological University and Groningen, the Netherlands: LASHIPA, 2007).
}

254 Dole, America in Spitsbergen, ii, 149. 


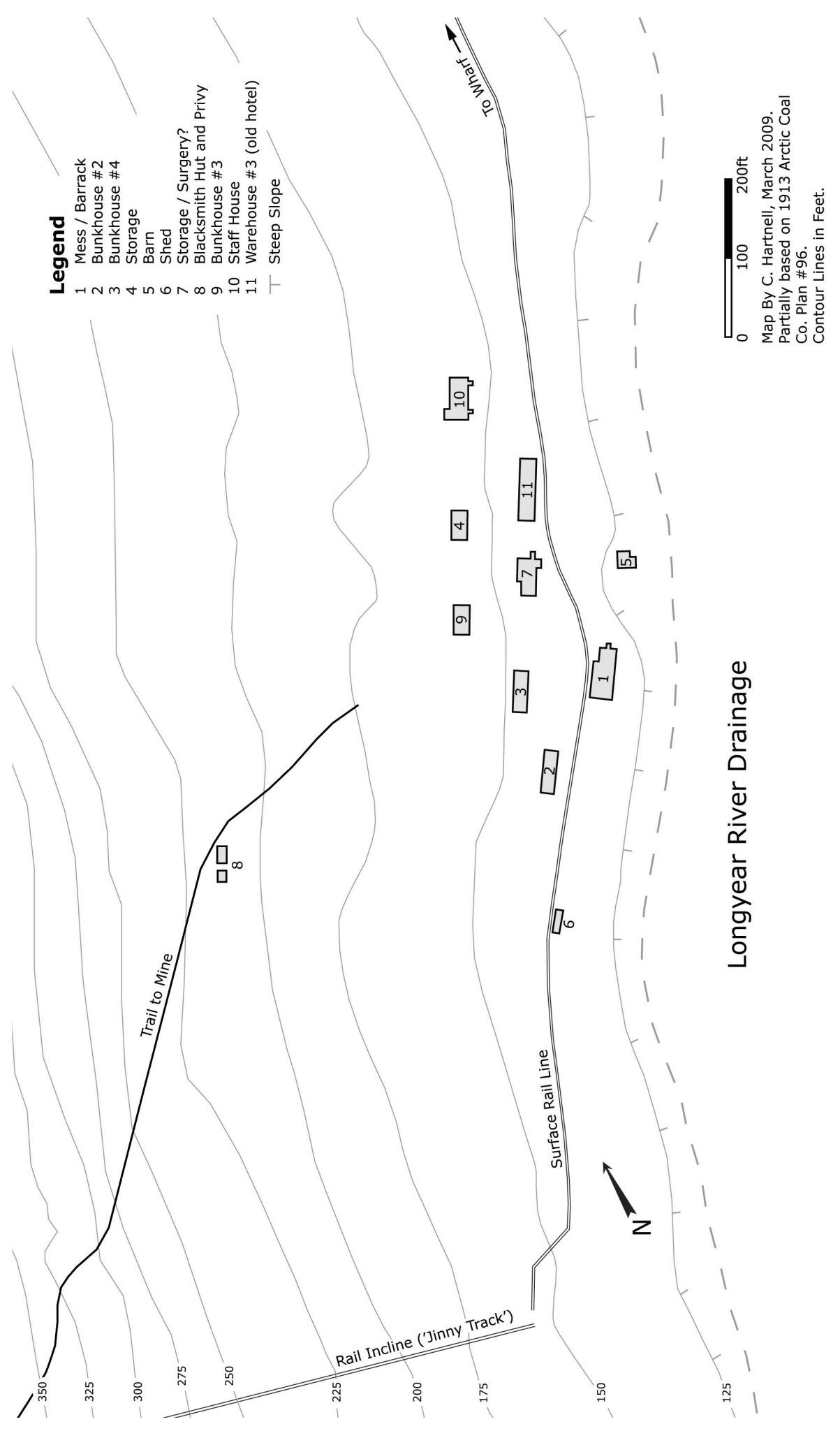

Figure 5.4 Plan of Longyear City in 1908. The Arctic Coal Company laid out the early town as a simple group of buildings that conformed to local topography. Map by Author, March 2009. 
The simple design of the housing initially failed to adequately protect inhabitants in periods of particular cold and high winds. Winter Superintendent Bert Mangham complained to his superiors about the housing conditions and pointed to the problems it caused:

"During this winter, the men have complained very much about the Barracks being inadequate to keep out the wind, and several times the men have called me in to look at their beds, which have been coated with ice around the sides and bottoms of the Bunks $2 "+3$ " thick, which has melted whenever the temperature had gone up + the floor + bed has been covered with water and freezes again just as soon as the glass goes down again as with a high wind. The room where Gibbs + Housley have lived has been bad + they have not dared to let the fires get low or they would have been frost bitten in bed when sleeping, and whenever there is a blizzard, of which we get one every few days in the dark season the wind and fine snow penetrates into the rooms + freezes everything, the same applies to my rooms, for example a pitcher of water left on the table will be just a solid block of ice next morning + everything liquid is frozen up solid. This is caused by the Boards not been airtight + with a SE Blizzard, not only wind, but fine snow will find its way into the rooms, making it very uncomfortable + impossible for anybody to keep warm.

The men's eating room is not good + is too cold in the winter, + the steam from the ice melting pan fills the whole room with a fog causing the men to be discontented + bad tempered in the dark season all of which I have to bear the brunt of in the dark season, when most of the men are bad tempered + moody. It will not cost the company much more to put up good living houses than bad ones, + will be better for the men and the Co. + will obviate most of the discontent + will leverage the men to stay more than 1 year, as it is not good to train a man as a coal miner + then loose him, just when he will benefit the Co.” 255

Mangham's arguments appears to have pushed the company to improve its housing by building structures with two air pockets and three layers of building

255 Letter from Bert Mangham to the Arctic Coal Company, May 30, 1908. Statsarkivet i Tromsø, Arctic Coal Company Collection (Privatarkiv Nr. 101), box 6, folder 'M 1908.' 
paper, although the documentation on the company reviewed for this work revealed almost nothing further on specific construction details. ${ }^{256}$

\begin{tabular}{|l|l|l|l|}
\hline No. & Building Name & $\begin{array}{l}\text { Intended No. } \\
\text { of Inhabitants }\end{array}$ & $\begin{array}{l}\text { Average Square Feet } \\
\text { per Man }\end{array}$ \\
\hline & General Workforce & & \\
\hline 1 & Mess/Boarding House & $?$ & Bunk beds? \\
\hline 9 & Barrack \#3 & 20 & 35'sq./man \\
\hline 2 & Barrack \#2 & $\begin{array}{l}\text { Similar to } \\
\text { Barrack \#3 }\end{array}$ & Similar to Barrack \#3 \\
\hline 3 & Barrack \#4 & $\begin{array}{l}\text { Similar to } \\
\text { Barrack \#3 }\end{array}$ & Similar to Barrack \#3 \\
\hline 10 & Staff House & ? & $\begin{array}{l}\text { Some } \\
\text { Management } \\
\text { accommodations }\end{array}$ \\
\hline- & $\begin{array}{l}\text { Engineer's House } \\
\text { (Advent Point) }\end{array}$ & ?anagemeng \\
\hline
\end{tabular}

Table 5.1 Table shows the housing available for the Arctic Coal Company's operations surrounding mine \#1. The table shows that the company had a very limited diversity in housing types with little room for workers and limited accommodations for management. Longyear City had no specific room for families and poor accommodations for professionals compared with mining operations in the US.

256 Dole writes that some of the houses erected in 1907 had this type of construction. This date does not exactly match Mangham's complaint but is close enough to suggest a small error by Dole. Dole, America in Spitsbergen, ii, 149. 


\section{Bunkhouse \#3 for 20 men - Longyear City}

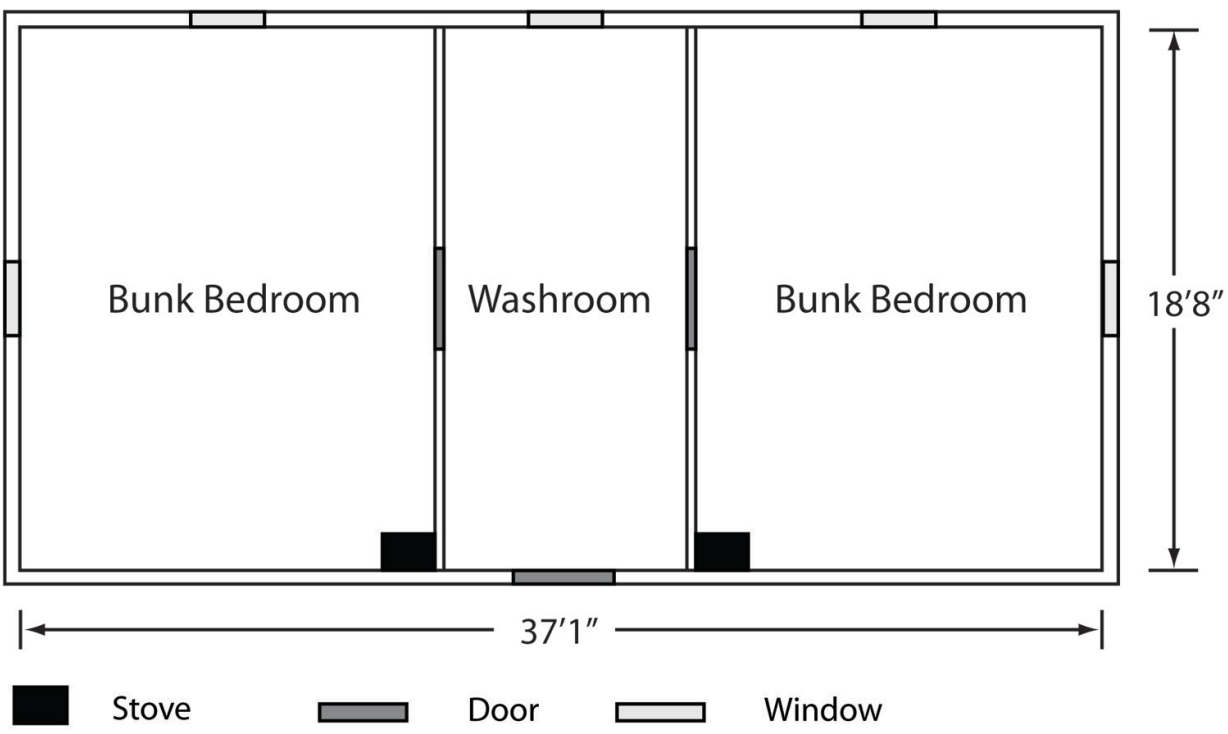

Plan by C. Hartnell, March 2009

Based on Arctic Coal Company Plan by Bert Mangham, May 30, 1908

Location of windows and stoves based on historic photographs

Location of internal doors is speculative

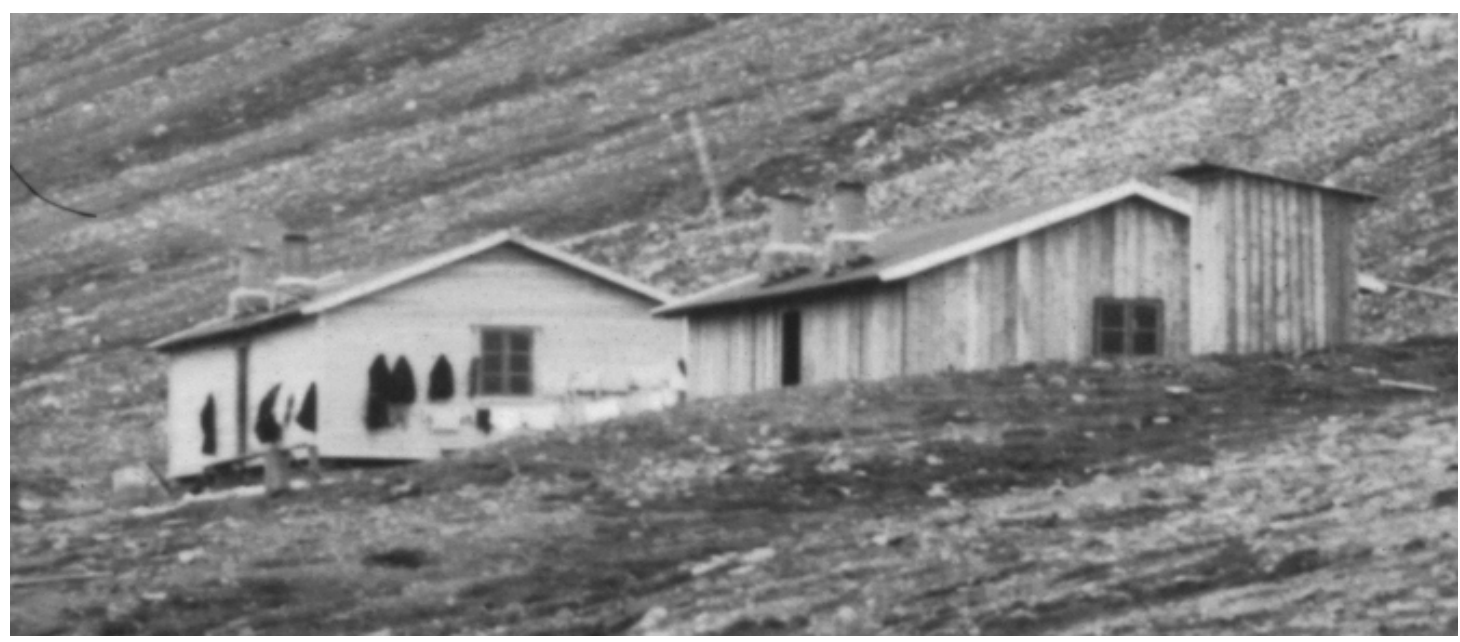

Figures 5.5 and 5.6 plan and 1908 photograph of Bunkhouse \# 3 that the company built in 1908

to house 20 workers. Plan by author, March 2009, based on plan by Bert Mangham, May 30, 1908, Statsarkivet i Tromsø, Arctic Coal Company Collection (Privatarkiv Nr. 101), box 6, folder 'M 1908.' The photograph shows bunkhouse \# 3 (left), a storehouse, later moved, possibly becoming bunkhouse \#1 (middle), and a privy (right). Michigan Technological University Archives and Copper Country Historical Collections, Michigan Technological University, Keweenaw Digital Archives, MSo18-007-02-10. 
The housing at Longyear City had implications for the type of workforce the company hired. Table 5.1 shows that Longyear City presented a limited diversity in housing types with either bunks or larger management accommodations. This allowed for only the simplest social hierarchy: management had the largest space and independent eating areas while workers had cramped conditions with a single eating mess. Some mid-level accommodation may have been available in the Engineer's house on Advent Bay to house some mid-level staff, although its distance from camp would have made its use difficult. Longyear City appears to have allowed no one any permanent, independent space to build a life on Spitsbergen and there was no space for families. Even the General Manager probably gave up his space in the staff house to the Winter Superintendent at the end of summer. The company made little extra provision for mining professionals and the city provided cramped and temporary accommodations for everyone.

The company found that keeping its workforce in group accommodations encouraged bad behavior and united action. Figures 5.5 and 5.6 show a plan and photograph of barrack \#3, which likely had a similar design to the two other barracks then in use. The workers slept together in two rooms, each warmed by a coal stove and with two windows. The structure only has facilities for sleeping (outer rooms) and washing (center room) and has no facilities for entertainment.

Even by the beginning of 1908, company management had begun looking at ways of diversifying housing options and breaking away from the bunk house model. John Gibson, by then former General Manager, suggested to his successor, Frederick Burrall, that the company change its approach. He stood against the mass accommodation of men in bunk houses and argued that the company should put its housing in the hands of contractors or private boarding-house keepers. The company would then sell goods to 
the men through the company store at a potential profit. He also suggested the company begin erecting family houses so the best men could bring their wives and possibly board some of the other workers. ${ }^{257}$

Operational pressures forced the company to delay any such plans. In 1908, the Arctic Coal Company needed to focus its manpower on completing its basic industrial system to get mining underway. Its first priority in the town was simply to have space to house the workers who would accomplish this goal and then to have basic office and storage available. Little capacity remained to nuance its building stock.

\section{Phase 2 (1909 - 1911): The Expansion of Longyear City}

Chapter 4 showed that in 1909 the Arctic Coal Company reviewed the whole undertaking. The company had just started to operate its mines and sent in a coal engineer to evaluate the progress made on the network and suggest the best path forward, largely based on his recommendations. The company used the remainder of this period to expand and enhance its existing industrial facilities and began to adapt to the Arctic environment. A similar pattern is visible in Longyear City where the company expanded the town with a broader range of settlement facilities that encouraged a more diversified workforce and better equipped organization.

In line with its work on the technical system, the company moved forward on expanding the town even before receiving recommendations from its consultant coal engineer, $\mathrm{W}$. L. Coulson. In 1909, it built a 1 1/2 story stable below the rail line and adjacent the bluff, near other similar structures. The building could house twelve animals, probably horses

257 Letter from John Gibson to Frederick P. Burrall, February 6, 1908. Michigan Technological University Archives and Copper Country Historical Collections, Longyear Spitsbergen Collection (MS-031), box 4, folder 19. 
and cows, feed and equipment. The facility provided permanent accommodations that replaced small temporary wooden sheds and enhanced the network by providing space for a larger animal stock that could be used for work and food. It built the structure from concrete in an experiment of that year to see how the material would work in Spitsbergen's climate.

Concrete offered the company a cheaper alternative to timber because using local stone and water as mixers reduced costs significantly. Cement also took less space than wood on board transporting ships, leaving more space for men and other goods. General Manager, Frederick Burrall, first tested concrete while building warehouse \#1 the same year, where workers broke local stone by hand on the project. ${ }^{25}$ Satisfied with the results, he proceeded with concrete for the stables, the powerhouse foundation and reinstallation of the foundation under the coal hopper at the mine.

In 1909 Coulson inspected the operations, focusing mostly on geographic and technical questions but did make one important recommendation on housing. He viewed the biannual change-over of an unskilled workforce as unsatisfactory for such a mining enterprise and suggested that the company provide comfortable housing and space for families to encourage a more permanent workforce: "the workmen will be better satisfied with their families with them." ${ }^{259}$ To do that, he recommended the construction of five double houses.

258 Letter from Frederick Burrall, General Manager of the Arctic Coal Company, to John Munroe Longyear, President of the Arctic Coal Company, May 12, 1909, Michigan Technological University Archives and Copper Country Historical Collections, Longyear Spitsbergen Collection (MS-031), box 4, folder 20.

259 Report by W.D. Coulson to the Arctic Coal Company, October 6, 1909. Michigan Technological University Archives and Copper Country Historical Collections, Scott Turner Collection (MS-018), box Z folder 11. 
The company accepted Coulson's recommendations and designed new double house buildings, although they called the structures barracks. As with the technical system, the company used the summer of 1910 to implement major building projects. That year it built three boarding houses of the same design almost 400 feet to the south of the existing settlement. Their position followed the main town corridor, as did a dirt path that ran through it. Also that year, the company upgraded its surface rail line and altered its alignment to run directly through this corridor before heading up hill to the base of the rail incline. Both actions enhanced this route's status as the main axis through town. In 1910 or 1911, it moved the engineer's house from Advent Bay to the wharfing and storage area. ${ }^{260}$

Both the new surface rail line alignment and the position of the boarding houses show that the company had moved away from using topography as the dominant guide to laying out facilities. Figure 5.7 shows how they resisted the contour of the land to meet the social goal of improving the town's layout around a central corridor. The same is true for the rail line. Cut and fill techniques allowed it to follow a straighter course and avoid the minor dips and mounds on the landscape.

260 This study has not found any reference to the use of this structure. 


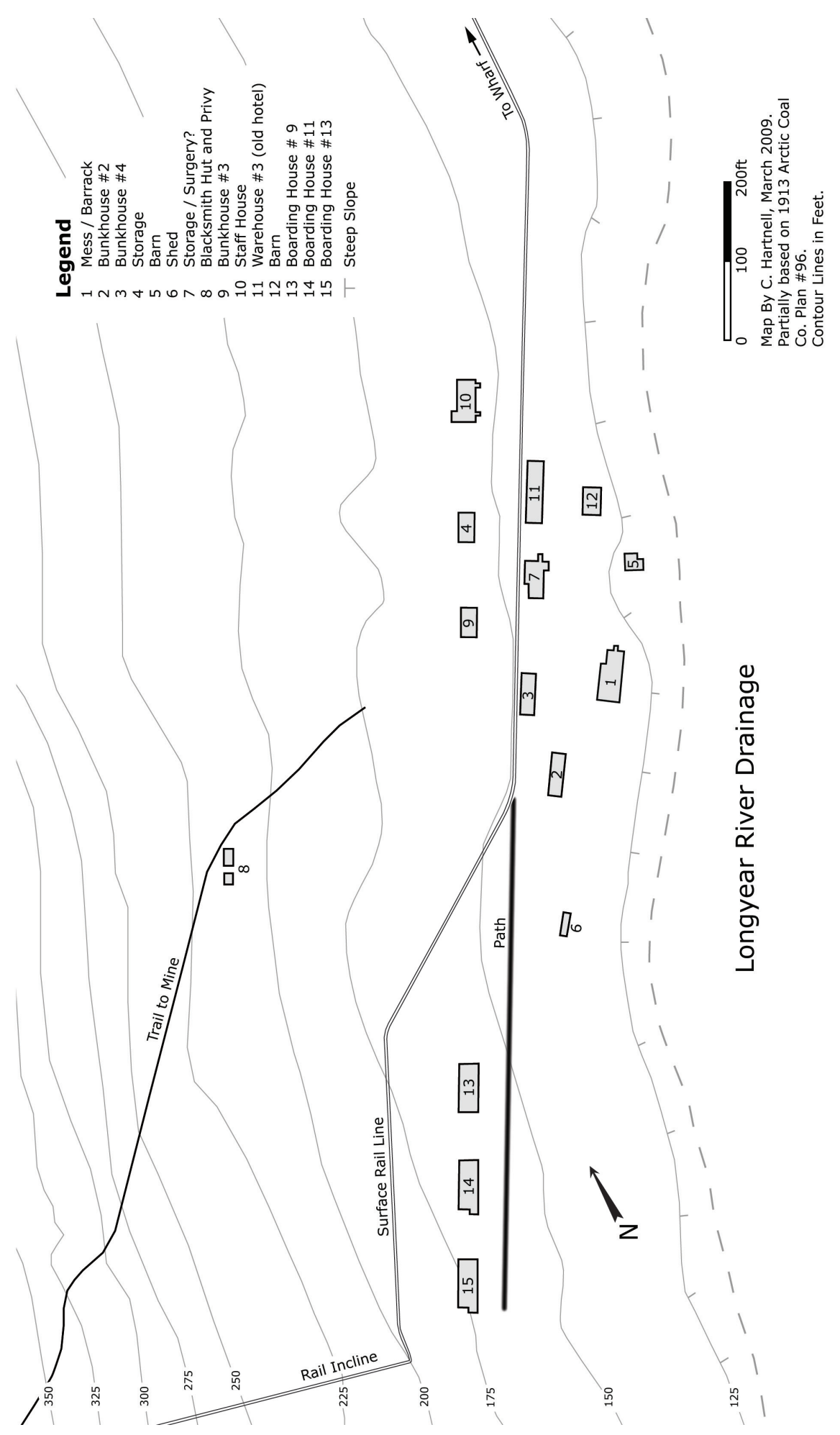

Figure 5.7 Plan of Longyear City in 1911. The altered alignment and positions of three new double houses (boarding houses \#9, \#11, \#13) resist the slope of the landscape. Map by author, March 2009. 


\begin{tabular}{|c|c|c|c|}
\hline No. & Building Name & $\begin{array}{l}\text { Intended No. of } \\
\text { Inhabitants }\end{array}$ & $\begin{array}{l}\text { Average Square Feet per } \\
\text { Man }\end{array}$ \\
\hline & General Workforce & & \\
\hline 1 & Mess/Boarding House & ? & Bunkbed facilities? \\
\hline 9 & Barrack \# 3 & 20 & 35 'sq./man \\
\hline 2 & Barrack \#2 & $\begin{array}{l}\text { Similar to } \\
\text { Barrack \#3 }\end{array}$ & Similar to Barrack \# 3 \\
\hline 3 & Barrack \#4 & $\begin{array}{l}\text { Similar to } \\
\text { Barrack \#3 }\end{array}$ & Similar to Barrack \#3 \\
\hline & Skilled Workers & & \\
\hline- & $\begin{array}{l}\text { Engineer's House } \\
\text { (Wharfing Area) }\end{array}$ & $?$ & Mixed room and bunk facilities? \\
\hline 10 & Staff House & $1+$ & $\begin{array}{l}\text { Approximately } 1300 \text { 'sq. for } \\
\text { office, dining \& accommodations }\end{array}$ \\
\hline & (Families / Boarders) & & \\
\hline 13 & Barrack \#9 & $\begin{array}{l}\text { - } 2 \text { Couples } \\
\text { - } 16 \text { Boarders }\end{array}$ & $\begin{array}{l}\text { - 307.2'sq./couple } \\
\text { - 51.6'sq./ man }\end{array}$ \\
\hline 14 & Barrack \#11 & $\begin{array}{l}-2 \text { Couples } \\
-16 \text { Boarders }\end{array}$ & $\begin{array}{l}\text { - 307.2'sq./couple } \\
\text { - 51.6'sq./ man }\end{array}$ \\
\hline 15 & Barrack \#13 & $\begin{array}{l}-2 \text { Couples } \\
\text { - } 16 \text { Boarders }\end{array}$ & $\begin{array}{l}\text { - 307.2'sq./couple } \\
\text { - 51.6'sq./ man }\end{array}$ \\
\hline
\end{tabular}

Table 5.2 Table showing the spread of accommodation types available in Longyear city at the end of 1911. The addition of three barracks provided accommodations for mid-level employees that had been previously lacking. 
Boarding House, Longyear City

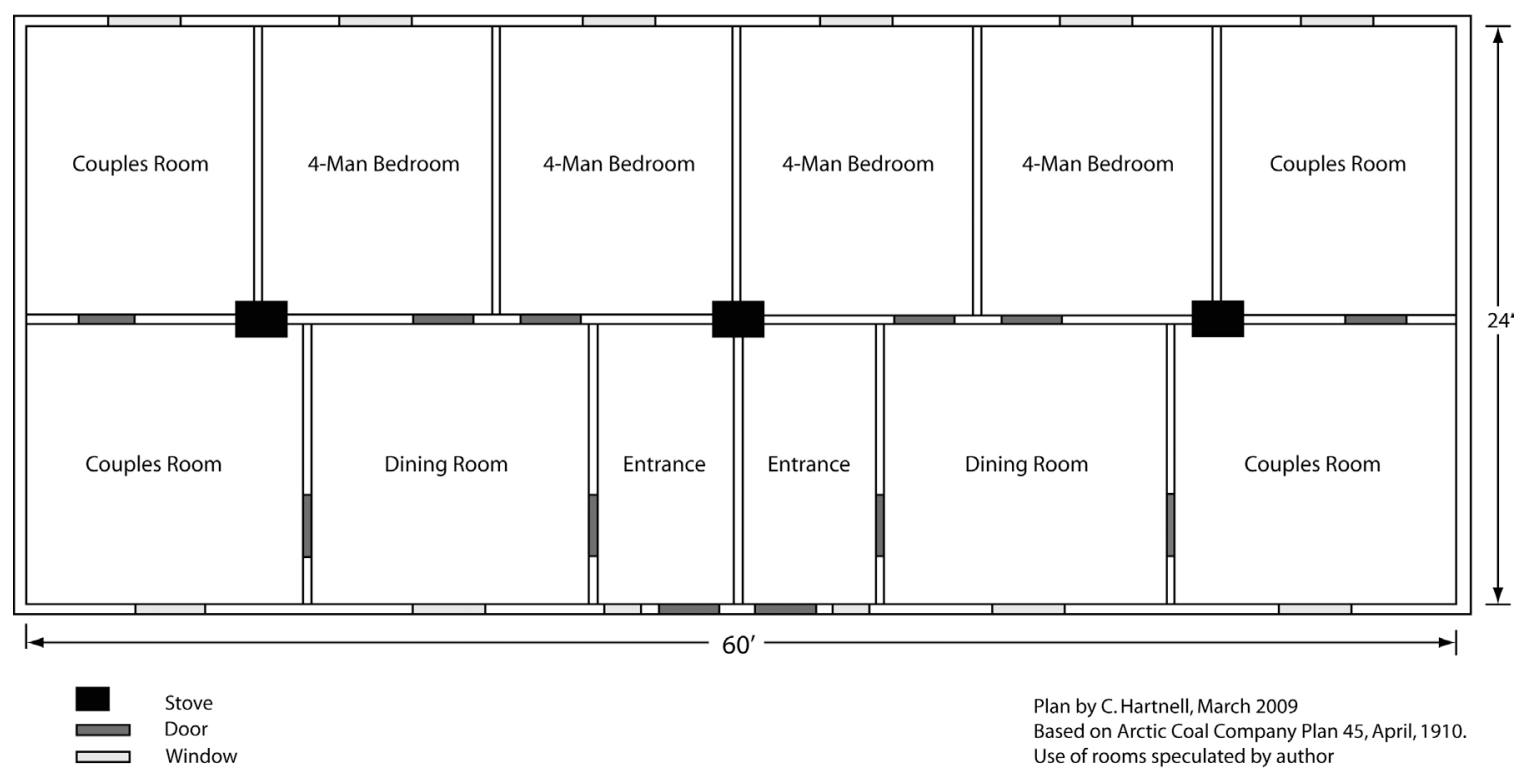

Figure 5.8 Plan of boarding houses \#9, \#11, \#13, built in 1910. Drawn by author, March 2009. The company designed this structure to encourage families to live in Longyear City and to break workers into smaller units. The company hoped that the wives of men would board workers living here but only one family ever undertook that role. Based on Arctic Coal Company Plan 45, Statsarkivet i Tromsø, Arctic Coal Company Collection (Collection \#101), box 106.

The boarding houses provided a new type of living space for the operations that improved facilities available for skilled workers and intended to improve and alter the way unskilled workers lived. Figures 5.8 and 5.9 show a plan and photograph of them and table 5.2 shows how the structures expanded the range of accommodations available in the settlement. The company hoped that up to six married couples would join the company, live in the apartments at either end of the buildings and each room and board eight workers using goods purchased from the company store. Four bedrooms in each double house, each of 144'sq., would provide boarding workers more individual room than the existing barracks. As these men were to eat independently from the rest of the workforce and sleep in smaller groups, the houses represent an attempt to defend the network against dislocation from labor resistance by breaking apart the mass of the 
workforce and thereby, hopefully, make it more manageable. The location of the boarding houses away from the town center further emphasized this separation. The general workforce paid \$0.40 per day, or Kr.1.50, for room and board, which compared favorably with the pay of Kr.5-6 per day, higher for contract work. Skilled workers received significantly higher wages and often paid nothing for room and board.

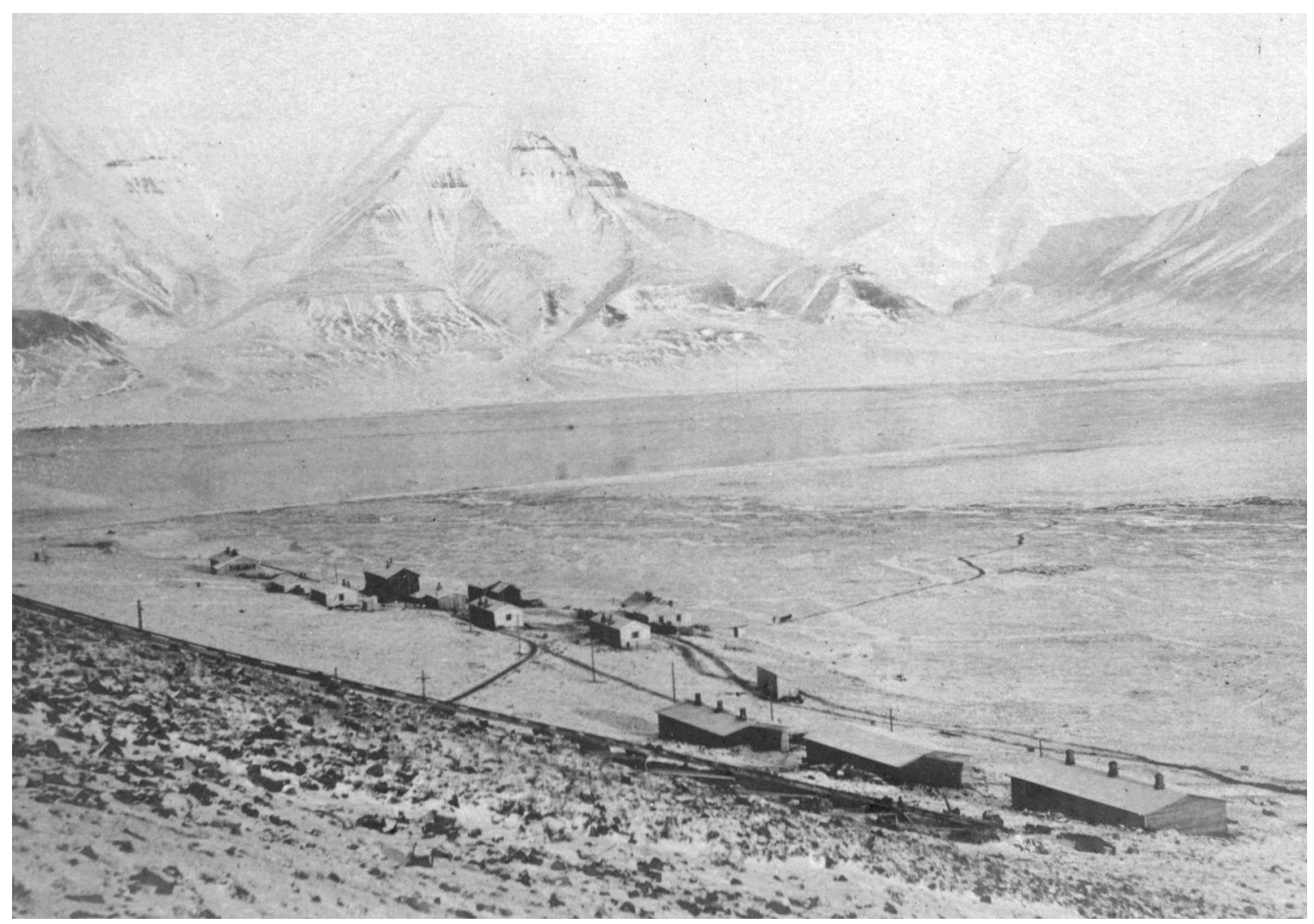

Figure 5.9 Photograph of Longyear City in 1910-1911. The company's three new boarding houses are visible in the foreground (bottom right), removed from the rest of town. Michigan Technological University Archives and Copper Country Historical Collections, Michigan Technological University, Keweenaw Digital Archives, MSo31-01-01-21.

At first the houses did not fulfill their intention as the company balked at bringing women to such an extreme climate. By this time, only a few women had come to the settlement, the majority being guests of upper management. Mrs. Munroe accompanied her husband for at least one summer's work while her friend, Mrs. Brigham, worked in 
camp over two summers making furniture out of boxes. ${ }^{261}$ Outside these, very few women except a cook and perhaps a housekeeper for the Superintendent lived at Longyear City. General Manager John Gibson felt that one woman overwintering over 1909-1910 caused so much trouble that he became reluctant to allow any more until 1912, in fear that the winter climate was too much for them. The annual report shows that three women overwintered over 1910-1911 but does not say if these women were wives of employees or employees themselves. ${ }^{262}$

\section{Phase 3 (1912-1916): Expanding the City}

On taking the position of General Manager, Scott Turner sought to greatly expand the living facilities at Longyear City. In only two years, he oversaw the provision of many more sleeping places by erecting new buildings and significantly expanding storage space, thereby alleviated the need to use housing for storage. While doing so, he increasingly relied on concrete as a construction material. In Longyear City, the construction flanked the railway and main road but the company also erected houses in other parts of the valley. After 1913, even though the Superintendent's house remained incomplete, the company ceased work on the settlement and concentrated on mining.

More than simply providing more sleeping berths, he continued broadening the type of housing available in an attempt to encourage the enrollment of a better workforce. Single houses and a four-apartment house provided independent quarters for high-level employees and their families. Mid-level skilled workers received more space in

261 Dole, America in Spitsbergen, i, 284.

262 Arctic Coal Company Annual Report for the year ending October 27, 1910, Michigan Technological University Archives and Copper Country Historical Collections, Longyear Spitsbergen Collection (MS-031), box 4, folder 23. 
individual rooms while new bunkhouses offered larger and more independent facilities to some unskilled workers. The documentary evidence suggests this housing diversity reflects both an organizational and ethnic hierarchy at play, and reflects Turner's strategy to rely more heavily on foremen in the operations. In this way, Turner tried to use company housing as a tool to control the workforce better, thereby defending the network against labor resistance.

Turner matched changes to the workforce with new construction in Longyear City. He significantly augmented the size of the summer and winter workforces from 1912, as shown by table 5.4, and built more accommodations to house them. To do so, he greatly expanded the most basic barrack accommodation with a 40 foot extension to the original barrack to then accommodate up to 300 men and by moving a small house from Advent City to house another 50 . He also built a large bunkhouse that accommodated 64 men in 16 rooms, which provided the workers more individual space than the barracks. Based on his satisfaction with that building, he replicated it in 1913 .

Also in 1912, Turner began to experiment with the workforce along ethnic lines. That year he diminished the size of the Norwegian force by hiring more Finnish men. These men presumably lived in the bunkhouses and barracks. He also began hiring more Americans and English men in higher ranking positions. For these men he had two types of family house built. Two individual family houses, each with four rooms and two stoves and internal bathroom, and one house with four 3-room apartments, providing space for four families. Turner's allocation of the facilities suggests that the social hierarchy of the company ran along both organizational ranking and ethnic lines. American's received the best accommodation as two American couples moved into the two independent houses, adjacent to the staff house. While one of the men held a high position in the company, 
the other did not. He was an American master mechanic and electrician who worked under an Englishman on the company's power system. That Englishman received lesser accommodations, either in one of the boarding houses or in the 4-apartment family house. The other English foremen, along with one German and one American, lived in the three boarding houses (double houses). ${ }^{263}$

Turner's 1912 approach ignored a strategy proposed by the previous General Manager and approved by the board. John Gibson had recommended the company build a house for foremen in 1912 but instead Turner proceeded with the strategy outlined above. When his labor experiments did not meet expectations, Turner decided to change course back towards Gibson's earlier approach, based on encouraging work shown by four or five Norwegian outdoor foremen. For the summer 1913 workforce, he directed the company to hire good quality Norwegian foremen who would chose around 20 of their own workers. ${ }^{264}$ In line with these efforts he had a house built for fourteen foremen with space in town for their own mess. The facility greatly expanded the company's ability to hire and maintain a middle-management workforce. The documentary evidence examined has not shown which foremen lived in these new accommodations but its use by Norwegian foremen seems likely. Table 5.5 shows the breakdown of the workforce in 1913 and 1914 by ethnicity. Turner used the same strategy to hire women employees, whereby one woman foreman hired the rest of the women employees and was responsible for them. ${ }^{265}$ This study has not found evidence of the number of female

263 Arctic Coal Company Annual Report covering the year 1911-1912, J.M. Longyear Research Library Archive, Longyear Spitsbergen Collection, Spitsbergen Papers \# 3 .

264 Letter from Scott Turner, General Manager of the Arctic Coal Company, to the Arctic Coal Company, October 14, 1912, Michigan Technical University Archives and Copper Country Historical Collections, Longyear Spitsbergen Collection (MS-031), box 5, folder 4.

265 Dole, America in Spitsbergen, ii, 295. 
employees, nor where they lived at camp although the company probably isolated them from the rest of the men in a separate housing facility.

\begin{tabular}{|c|c|c|c|}
\hline No. & Building Name & $\begin{array}{l}\text { Intended No. } \\
\text { of Inhabitants }\end{array}$ & $\begin{array}{l}\text { Average Square Feet per } \\
\text { Man }\end{array}$ \\
\hline & General Workforce & & \\
\hline 1 & Mess/Boarding House & 300 & Estimated 7.2 ' sq./man \\
\hline 18 & Bunkhouse \#7 & 50 & Approx. 11.65'sq..man \\
\hline 17 & Bunkhouse \#5 & 64 & 30.47’sq./man \\
\hline 25 & Bunkhouse \#6 & 64 & 30.47'sq./man + basement \\
\hline 9 & Barrack \#3 & 20 & 35 'sq./man \\
\hline 6 & Barrack \#1 & $\begin{array}{l}\text { Similar to } \\
\text { Barrack \#3 }\end{array}$ & $\begin{array}{l}\text { Similar to Barrack \#3 + } \\
\text { basement }\end{array}$ \\
\hline 2 & Barrack \#2 & $\begin{array}{l}\text { Similar to } \\
\text { Barrack \#3 }\end{array}$ & Similar to Barrack \# 3 \\
\hline 3 & Barrack \#4 & $\begin{array}{l}\text { Similar to } \\
\text { Barrack \#3 }\end{array}$ & Similar to Barrack \# 3 \\
\hline- & $\begin{array}{l}\text { Bunkhouse \#8 (Small } \\
\text { settlement to the north, near } \\
\text { wharfing and storage area) }\end{array}$ & ? & $?$ \\
\hline- & $\begin{array}{l}\text { Bunkhouse \#17 } \\
\text { (adjacent Bunkhouse \#8) }\end{array}$ & $?$ & $?$ \\
\hline- & Barrack at Mine \#2 & 8 & 72.25 'sq./man \\
\hline
\end{tabular}




\begin{tabular}{|c|c|c|c|}
\hline & Skilled Workers & & \\
\hline - & $\begin{array}{l}\text { Engineer's House (in wharfing } \\
\text { and storage Area) }\end{array}$ & $?$ & $?$ \\
\hline 24 & Foremen's House & 14 & 151.3'sq./man \\
\hline 13 & Barrack \#9 & $\begin{array}{l}-2 \text { Couples } \\
\text { - } 16 \text { Boarders }\end{array}$ & $\begin{array}{l}\text { - 307.2'sq./couple } \\
\text { - 51.6'sq./ man }\end{array}$ \\
\hline 14 & Barrack \#11 & $\begin{array}{l}-2 \text { Couples } \\
-16 \text { Boarders }\end{array}$ & $\begin{array}{l}\text { - 307.2'sq./couple } \\
\text { - 51.6'sq./ man }\end{array}$ \\
\hline 15 & Barrack \#13 & $\begin{array}{l}-2 \text { Couples } \\
-16 \text { Boarders }\end{array}$ & $\begin{array}{l}\text { - 307.2'sq./couple } \\
\text { - 51.6'sq./ man }\end{array}$ \\
\hline 16 & Family House & 4 Families & 291.45’sq./ family \\
\hline 20 & Cottage \# 1 & 1 Family & 632.18'sq./ family \\
\hline 21 & Cottage \#2 & 1 Family & 632.18'sq./ family \\
\hline 23 & Cottage \#3 & 1 Family & 632.18'sq./family \\
\hline 22 & Superintendents House & 1 & $\begin{array}{l}\text { Approx. } 963.2 \text { 'sq./family } \\
\text { (Only basement completed) }\end{array}$ \\
\hline 10 & Staff House & $1+$ & $\begin{array}{l}\text { Approximately 1300'sq. for } \\
\text { office, dining and } \\
\text { accommodations }\end{array}$ \\
\hline
\end{tabular}

Table 5.3 shows the breadth of accommodation types in Longyear City at the close of business in 1916, which stood in essentially the same form from the end of 1913.

Also in 1913, Turner began to expand the number of Americans in upper level management positions, who he had work over the winter and summer months. 
Previously, Americans had never worked over winter. In line with that expansion, Turner had one more cottage built at the northern end of town with the same design as those built in 1912. Table 5.3 shows the breadth of accommodations in Longyear Valley by the sale of the enterprise in 1916, the same as it was at the end of 1913.

The ethnic approach to housing never totally dominated the company's housing policy, only helped to shape it. From 1913, some Norwegian and English workers brought their wives and lived in family housing. The company even provided an English mine foreman, W. H. Gibbs, with cottage \# 2, the best family accommodations then available. ${ }^{266}$ Gibbs probably earned the right to the place as he had worked for the company since at least 1907.

At the same time as these developments, Turner confronted increasing pressures on storage space and shifted most construction to concrete materials. Turner found that despite the construction of a new warehouse in 1912 "at least double the warehouse room was needed. Material and supplies had to be scattered through the bunkhouses and camp buildings, stored in three lighters, and piled in many places on the ground without any roof over them.”267 This forced some English foremen into a bunkhouse, which then pushed sixteen unskilled workers into the stables. With limited eating space available, the company erected tents as temporary messes. Turner proposed a two year construction program over the summers of 1913 and 1914, including but not limited to

266 Letter from Frank Dalburg to W. H. Gibbs, July 14, 1914, Michigan Technical University Archives and Copper Country Historical Collections, Scott Turner Collection (MS-018), box AA folder 01.

267 General Manager's report for the year 1911-1912 by Scott Turner, March 27, 1913. Michigan Technical University Archives and Copper Country Historical Collections, Scott Turner Collection (MS-018), box Z folder 13. 
more housing, storage and a hospital and doctor's house. ${ }^{268}$ Ayer and Longyear approved one year's expansion, forcing Turner to scale back his plans.

To increase storage space, Turner had another warehouse constructed in 1913, another two in 1915 and used new concrete construction in the town as an opportunity to build basements to provide even more. Turner used concrete in some construction work of 1912 including a blacksmith shop, office and the mine portal to replace those lost in a fire at the mine in November 1911, and a new office building in Longyear City across from the staff house. The office building provided working space to allow the company to meet its upgraded accounting and design goals and featured a basement vault designed to hold records and valuables. The following year the Arctic Coal Company purchased a rock breaker that automated part of the concrete making process and allowing them to use concrete in most subsequent construction. ${ }^{269}$

The foremen's barrack received full concrete construction, save its roof. Bunkhouse \#6 also featured full concrete construction with a basement designed to hold 60 tons of potatoes with shelves and a hot water system. The company designed the new Superintendent's house to be made of concrete with a basement vault for the storage of up to 200 meat carcasses. Bunkhouse \#1, which may have been a storage house built in 1907 that the company moved in 1913 to make space for the foreman's barrack, sat on a

268 Arctic Coal Company General Managers Report for the year from Oct.1 1912 to Aug 31,1913, Michigan Technological University Archives and Copper Country Historical Collections, Longyear Spitsbergen Collection (MS-031), box 4, folder 13.

269 Arctic Coal Company General Managers Report for the year from Oct.1 1912 to Aug 31,1913, Michigan Technological University Archives and Copper Country Historical Collections, Longyear Spitsbergen Collection (MS-031), box 4, folder 13. 
high concrete foundation that appears to also be a storage basement. ${ }^{270}$ Photographic evidence suggests that company builders cut shallow trenches, perhaps down to permafrost, and poured concrete into timber frames. ${ }^{271}$ This approach avoided the difficulties associated with working in the permafrost by simply sitting atop it. So long as the basements remained cold, the permafrost remained solid and the building stable.

While the company had hoped to shift towards a system of boarders managed by others, it made little progress on this front and by the time of sale was still almost completely responsible for all aspects of housing and boarding men. During his visit to the operations in 1913, J. M. Longyear noted only one family boarding foremen, probably in one of the boarding houses at the southern end of town. ${ }^{272}$ At that time he expressed the hope in his journal that the company could get the whole boarding business on this basis but the company made no further progress in this direction. His concerns faced a real concern for the company. That year, the cost of simply operating the housing and feeding the men reached $\mathrm{Kr} .39,105.10$ (around \$10,400), 23\% of total general expenses and almost $9 \%$ of the coal production cost. The cost of housing and feeding the men had become a significant hindrance to making the operations viable.

2701915 photograph of Barrack \#1, Michigan Technological University Archives and Copper Country Historical Collections, Keweenaw Digital Archives, No Neg 2007-07-30-33.

271 Two photographs show the Arctic Coal Company building structures in concrete, both in Statsarkivet i Tromsø, Arctic Coal Company Collection (Privatarkiv Nr. 101), box 241. Photograph 110 shows the foundations of Barrack \#6 being prepared and photograph 115 shows the concrete formwork for the basement of the Superintendent's house.

272 Journal of John M. Longyear, July 5, 1913 - August 8, 1914, Transcribed by Mary Longyear Paul, J.M. Longyear Research Library and Archive, Longyear Spitsbergen Collection (MS-018), box 2. 


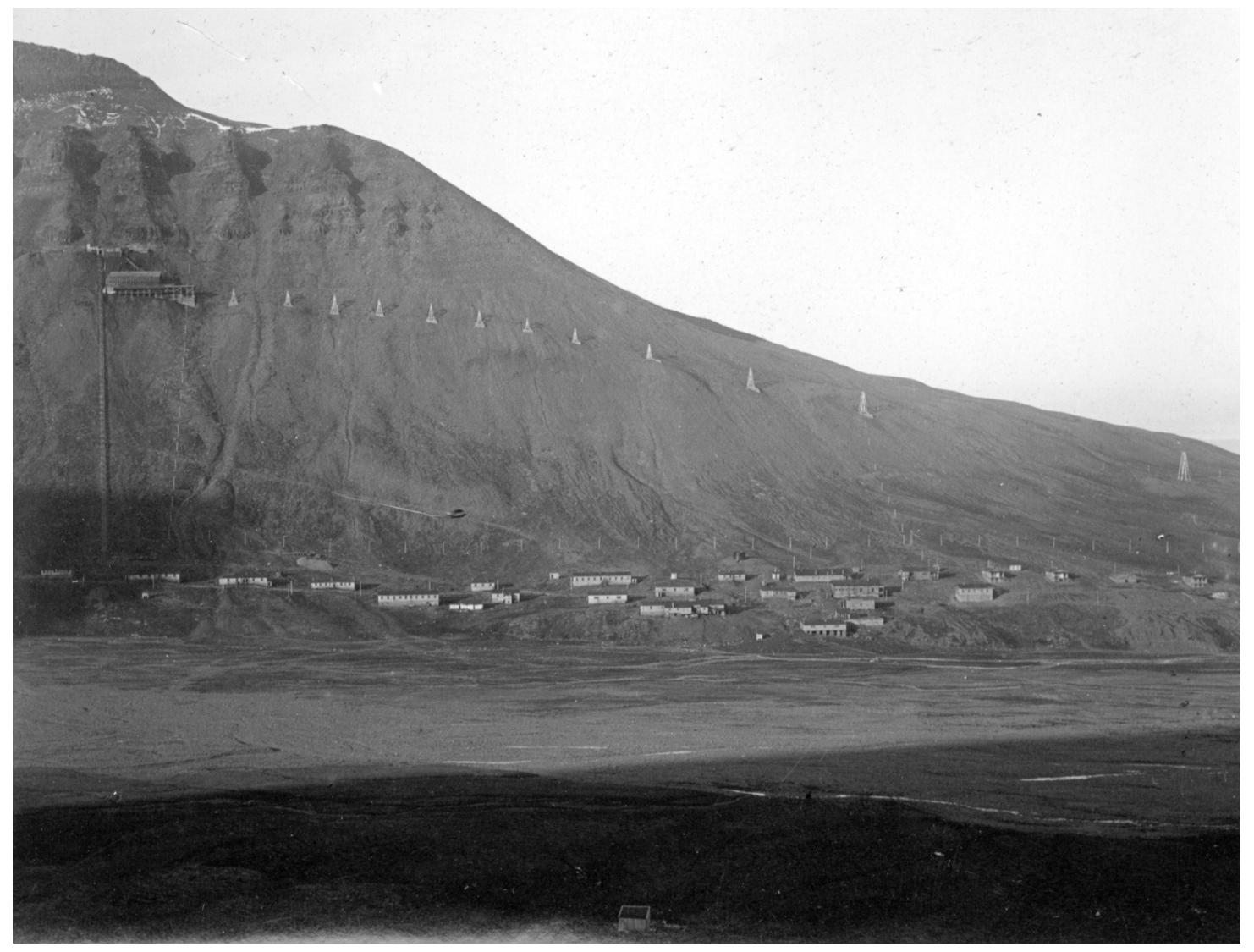

Figure 5.10 1915 photograph of Longyear City from the west side of Longyear Valley. This photograph shows the full extent of Longyear City as developed by the Arctic Coal Company. Michigan Technological University Archives and Copper Country Historical Collections, Michigan Technological University, Keweenaw Digital Archives, No Neg 2007-07-30-24. 


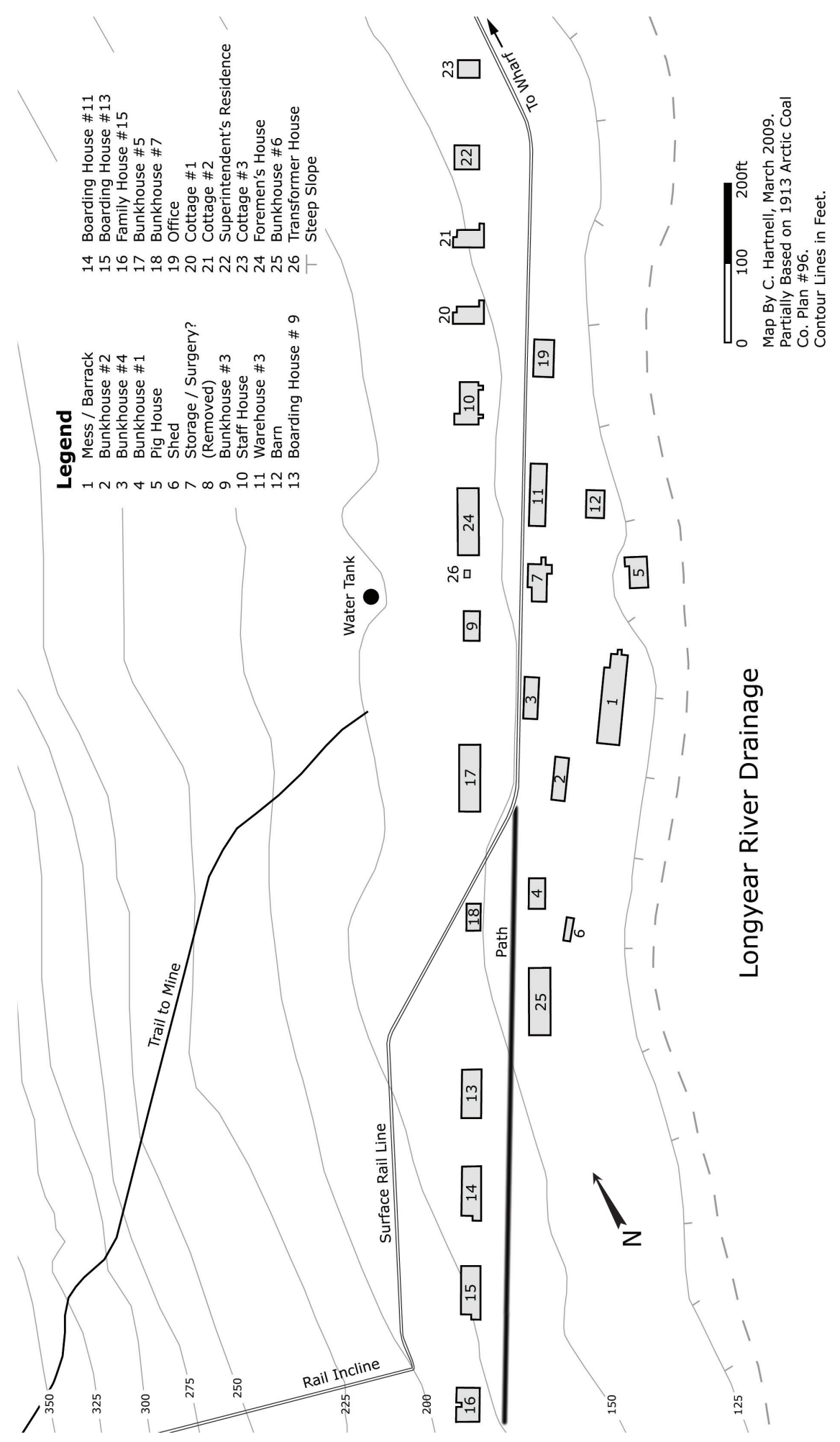

Figure 5.11 Plan of Longyear City in 1913-1916. A large building campaign under Scott Turner filled out the town, emphasizing the corridor of the surface rail line and further south. Plan by author, March 2009. 


\section{Broad View of the Development of Longyear City}

This section provides an overview of the main themes of Longyear City's development both to summarize the findings of the above analysis and to bring in notions that do not fit the above period history structure to allow for comparison with contemporary American company town practice, below.

The Arctic Coal Company built all the buildings in Longyear City and housed all of its workers. Table 5.4 shows the number of people inhabiting Longyear City under the Arctic Coal Company. Despite theoretically having space for over 700 people and employing much less than that, the settlement was often overcrowded. Table 5.5 shows how the workforce broke down ethnically from 1913-1914. Longyear City housed most of the workforce in bulk accommodations and with the sole exception of one family boarding some of the foremen, the company managed the accommodation and feeding of

all of its men. Far from providing greater control over its workforce, as the subsequent section will show was a common outcome at other American company towns, the provision of housing actually gave the company little control over its men. The bulk accommodation of men invited disruptive behavior and may have assisted the organization of strikes. Furthermore, management's control was diminished because Spitsbergen's extreme climate and geographic isolation forced them to house and feed men no matter how men acted towards the company. 


\begin{tabular}{|l|l|l|}
\hline Year & Summer & Winter \\
\hline 1905 & 27 & o \\
\hline 1906 & Over 80 & 23 \\
\hline 1907 & About 150 & About 40 \\
\hline 1908 & About 120 & 45 \\
\hline 1909 & 82 & 50 \\
\hline 1910 & 128 & 77 \\
\hline 1911 & 185 & 91 \\
\hline 1912 & Up to 311 & 210 \\
\hline 1913 & 275 average & 240 \\
\hline 1914 & 207 & 120 \\
\hline 1915 & Variable: $125-217$ & 3 \\
\hline 1916 & o (sold) & - \\
\hline
\end{tabular}

Table 5.4 Table showing the number of men employed at the Arctic Coal Company. The figures given for the summer months are approximate only as employee numbers fluctuated over that time. The numbers also exclude non-employed persons living in Arctic Coal Company accommodations, such as workers wives, which numbered up to around 20 people by the later years of operation. Table compiled by the author from Arctic Coal Company annual reports found in the MTU Archives and Copper Country Historical Collections and the US National Archives II. 


\begin{tabular}{|l|l|l|}
\hline Nationalities & Winter 1913/14 & Summer 1914 \\
\hline Norwegians & $74.0 \%$ & $62.3 \%$ \\
\hline Swedes & 13.6 & 14.0 \\
\hline Finns & 6.8 & 15.0 \\
\hline Russian & $\ldots$ & 3.3 \\
\hline German & 1.0 & .5 \\
\hline English & 4.1 & 4.0 \\
\hline Danish & .5 & .5 \\
\hline Unknown & $\ldots$ & .4 \\
\hline & $100 \%$ & $100 \%$ \\
\hline & $\begin{array}{l}225 \text { men on pay roll } \\
\text { No Americans }\end{array}$ & $\begin{array}{l}207 \text { men on pay roll } \\
\text { Including 10 Americans }\end{array}$ \\
\hline
\end{tabular}

Table 5.5 Arctic Coal Company survey of worker nationalities at the Advent Bay Operations, from note titled “Men Employed on Spitsbergen," author unknown, Michigan Technological University Archives and Copper Country Historical Collections, Scott Turner Collection (MS-018), box Z, folder Z11.

One of the most defining aspects of Longyear City is that it always remained a housing camp and never really became a community. The company attracted few long-term employees and the constant turnover of an impermanent seasonal workforce meant that the inhabitants had almost no collective memory of the development of the town and the 
history of the people therein. No one owned their own place, almost no one had control over their own space in the camp over sequential seasons and very few even had their own room. The workforce also had minimal opportunity to enjoy the place as Longyear insisted that the company not provide any facilities for recreation in the interests of thriftiness. To all inhabitants, this was a place of work, not a place to settle down.

The form of Longyear City seen at the point of sale in 1916 is the result of an evolutionary process of development rather than a formal town planning approach. As planning proceeded less than two years in advance of construction and usually within one year of the work, the buildings reflect the changing company attitudes towards housing, particularly the types of men it hoped to hire, visible in the forms of houses constructed. Rather than following a pattern of design, Longyear City features a great variety of types. Of the 23 buildings built by the Arctic Coal Company in Longyear City, excluding those brought across from Advent City, there are sixteen individual building forms. When including the wharfing and storage area, which has a set of totally unique building forms, that variety increases. Only five building designs are repeated, then only once or twice.

The town follows a linear pattern, one that initially followed environmental contours and then shifted to following a strict line on a roughly north-west/south-east axis from 1910. The buildings are mostly irregularly spaced on the landscape. Only two collections of houses have a regular spacing: the three boarding houses built in 1910 and the building surrounding and including the two cottages built in 1912. Otherwise the layout shows the company used a spacing method of rough estimation and immediate convenience of construction rather than by any formal town design process. Archival research has only found references by company officials on recommendations for types of buildings and no reference to broader development and layout patterns of the town. 
After 1909, the Arctic Coal Company continued and enhanced existing patterns of town layout. The buildings most associated with waste, such as the stables, pig house and large mess house, stood on the edge of the bluff over the Longyear River drainage, allowing easy disposal of waste. The rest of the town followed a town corridor a little up slope. By 1913 a vague hierarchical grouping was visible in the town's layout. The administrative buildings and housing for the highest level of workers stood on the northern end of town. The mid-section predominantly housed the general workforce while the southern housed skilled workers.

Preferring cheap, quick construction, the Arctic Coal Company always built single story, gable structures, the engineer's house built and the barn being exceptions at $1 \frac{1 / 2}{1}$ stories. While it started with double sheathed frame structures with simple board wall exteriors, it appears that the company moved to triple sheathed ones after strong complaints from its workers, and later to concrete construction. ${ }^{273}$ The housing proved adequate and no more. In winter storms, snow still made its way into the bedrooms of workers making them cold. ${ }^{274}$ No structure had internal running water, due to the severe lack of a stable water supply, and only the cottages seem to have had toilets accessible from inside.

Other than sleeping berths, housing structures generally only had a stove for melting ice for drinking and washing water and perhaps a mess. With the erection of the powerhouse in 1910, electric lights lit the houses. The men slept on simple wooden bunks

273 Dole, America in Spitsbergen, ii, 149.

274 Letter from Bert Mangham to the Arctic Coal Company, May 30, 1908. Statsarkivet i Tromsø, Arctic Coal Company Collection (Privatarkiv Nr. 101), box 6, folder 'M 1908,' and Letter from George Conant to W. B. Clark, June 29, 1913. Michigan Technological University Archives and Copper Country Historical Collections, Longyear Spitsbergen Collection (MS-031), box 5, folder 6. 
or iron spring beds and furniture was very simple, being made on site with wooden packing boxes or made on site with Norwegian lumber. ${ }^{275}$

Seeking to reduce costs and effort, the company was always willing to use short-cuts to housing construction whenever available. The company took three walls of a house from a historic Swedish camp on the Ice Fjord in 1905. From at least 1910, operations, the Arctic Coal Company began to salvage material from the Spitsbergen Coal and Trading Company's settlement, Advent City, paying the owners a fair value. ${ }^{276}$ At first they took small goods and equipment, possibly including house furnishings, doors and windows, although the records aren't specific. During 1912 - 1913, the Arctic Coal Company took five houses and probably also took a pig house. ${ }^{277}$ Over the winter of 1913-1914, the company hoped to take many more structures but stopped when it changed strategy to concentrate solely on mine development and production. In 1913, Scott Turner considered a novel alternative to formal housing; to tow hulks to Advent Bay, beach them and altering the decks and one under-story for barrack accommodations, leaving the lower decks for storage. He abandoned the plan before the outset of summer when he found that it would cost more than simply building more bunk-houses.

275 Mrs. Louise Brigham, a friend of Mrs. Munroe, stayed at camp over the summers of 19061907 to make furniture with discarded wooden packing boxes and later published described these efforts in a book: Brigham, Box Furniture. This project has located few photographs showing building interiors. Five photographs of Louise Brigham's furniture in the engineer's house are stored at Statsarkivet i Tromsø, Arctic Coal Company Collection (Privatarkiv Nr. 101), box 241, 117-121. A private photographic collection of Mr. Fred Tibbets has one photograph of the interior of an Arctic Coal Company mess hall.

276 Noted in John M. Longyear's Journal, July 5, 1913 - August 8, 1914, Transcribed by Mary Longyear Paul, J.M. Longyear Research Library and Archive, Longyear Spitsbergen Collection, box 2. The company showed its payments to the Spitsbergen Coal \& Trading Company in its Annual Reports.

277 These structures became Bunkhouses \#7, \#8 and \#17, the pig house, the bunkhouse at Mine 2. The Arctic Coal Company intended to place one hut at the head of the Flower Valley, now Bloomsterdalen, but appears not to have done so. The final location of that structure is not known to this project. 
Archival documentation includes few complaints of the cold living conditions, most contemporary accounts describe the housing as at least reasonably comfortable. On inspecting the town in $1913, \mathrm{~J}$. M. Longyear described the town in exactly these terms, ${ }^{278}$ as did a later account by Scott Turner. ${ }^{279}$ The company's doctor, A. Macaulay, replied to a request for information by the Norwegian group who eventually purchased the works by writing that the houses provided comfortable and sanitary accommodations, the company had good cooking facilities and the lack of any cases of infectious disease spoke highly of the good living conditions. ${ }^{280}$ These accounts suggest that the company's housing proved adequate for the purpose. Never the less, it is hard to imagine that the town provided a satisfying existence. A visiting Brit suggested that living there over the winter would probably be very dreary. ${ }^{281}$ The voice of the company's workmen is missing in this respect, although newspaper accounts provide an overwhelmingly negative view of the operations. ${ }^{282}$ Archival research has uncovered no account of the works from the point of view of a common Scandinavian worker that might shed light on this period of Spitsbergen's history.

278 Journal of John M. Longyear, July 5, 1913 - August 8, 1914, Transcribed by Mary Longyear Paul, J.M. Longyear Research Library and Archive, Longyear Spitsbergen Collection, box 2.

279 Turner, Scott, 'Mining in Spitsbergen,' Encyclopedia Arctica, 1949, Michigan Technological University Archives and Copper Country Historical Collections, Scott Turner Collection (MS-018), box Z, folder 18 .

280 Letter, A. Macaulay to the President CentralBanken, January 14, 1916. Statsarkivet i Tromsø, Arctic Coal Company Collection (Collection \#101), box 103, folder 'Folder - 1915-1916 Korrespondanse I Forbindelse Med Salg Av AC's Eiendommer.'

281 Atkinson, J.B. Spitsbergen Coal, 1913, 23. Riksarkivet, Spetsbergenarkivet, Vol. 4. Stockholm, Sweden.

282 In Norwegian newspapers including Dagsposten, Nordlys, Aftenposten, Dagbladet, Verdens Gang and Tidens Tegn. 


\section{Comparison with Company Town Practice in the United States}

Comparing Longyear City with different examples and trends allows identification of elements that are typical or unusual to this particular case and provides opportunities to better assess the qualities of the town and its relationship with company workers. The examples adopted were chosen for their relationship with different facets of Longyear City's design. They are mostly American because the Arctic Coal Company was owned and led by Americans.

Comparison with the American reform movement explains the extent that the Arctic Coal Company adopted contemporary philosophies regarding the relationship of companies with their workforce. The physical attributes of the settlement, including construction materials, floor-space and the provision of utilities are juxtaposed against company coal mining settlements in Pennsylvania and West Virginia, then the largest coal mining region in the US and related to Spitsbergen through the common type of mineral extracted. The Kennecott Mill Town, in south-central Alaska, and Kiruna, in Northern Sweden, offer two case studies of isolated contemporary mining camps situated in cold, northern climates.

The comparison is essential to establish a broader understanding of Arctic Coal Company's efforts and its relationship to the workforce. A review of anthropological practice by Carol S. Holzberg and Maureen J. Giovannini underscores the real importance of comparative analysis when related to labor. ${ }^{283}$ They observed that the bulk of anthropological studies on industrial settings used the case study method that correlated individual workplaces with small holistic communities. This approach framed

283 Holzberg, Carol S. and Maureen J. Giovannini, 1981, "Anthropology and Industry: Reappraisal and New Directions," Annual Review of Anthropology 10(181): 317-360. 
workplaces as integrated social systems with a stable social equilibrium. Most importantly, few studies compared findings with other industrial workplaces or related their sites with the communities associated with it, limiting the potential to challenge assumptions of social balance and potentially masking realities such as worker exploitation. The following comparisons resist any impulse to frame the Arctic Coal Company's works as a stable social equilibrium. Quite the opposite, it shows that the company's approach was at least in part responsible for a highly transient workforce.

\section{Contemporary American Attitudes Towards Company Housing}

Company housing has been associated with European and American industry for many centuries. By providing housing, industries located in isolated locales improved their ability to draw in the workers it needed to function. Housing also played a role in the types of workers a company attracted and the attitudes of the workforce towards a company. The quality of workers enlisted has a relationship with the level of pay and quality of life on offer compared with alternatives. Furthermore, the way companies interacted with their worker communities could have important impacts on the commitment and permanence of the workers towards their employers. All these factors played into the ongoing national dialogue over the approaches to worker housing and how best to bring together corporate interest with community needs.

The company town offers rich prospects for comparison because American industry depended on them so heavily. By the 1930's, the use of the company town in America peaked with around 2,000,00o inhabitants. ${ }^{284}$ Thousands of communities across the country followed similar patterns of development, which were the target of large scale

284 Metheny, Karen Bescherer, From the Miners' Doublehouse: Archaeology and Landscape in a Pennsylvania Coal Company Town (Knoxville: University of Tennessee Press, 2007), 1. 
government and social investigation and debate. Later scholars have examined these towns from all historic periods across the country allowing Longyear City to be placed within a strong historic contextual framework.

Margaret Crawford traces the changing form of company houses and the debate surrounding that change in America from the earliest forms in New England to the 1920s. ${ }^{285}$ Through much of the nineteenth century, companies regularly adopted paternalistic practices towards its workers, such as providing housing and community facilities with the expectation of exercising greater control over the workforce and gaining an increased commitment from it. A violent strike at Pullman, Illinois, that grabbed national attention in the 1890 s shook attitudes towards this approach. George Pullman created the Pullman Palace Car Company there and erected a town to house part of its workforce. He had the town professionally designed with attention to street layout, housing architecture and community facilities but insisted on extensive control over the lives of its inhabitants. The strike attracted criticism of Pullman's approaches and companies around the nation shied away from this form of paternalism.

A social era known as the 'progressive movement' followed from the 1890 s through the period of the Arctic Coal Company. With arguments based on assessments of the Pullman failure, the movement sought a middle ground between the power of large corporations and militant labor organizations through the provision of social services. Initially strongly identifying with protestant values, by the turn of the century rationality overtook the religious as the movement's defining value base. In doing so, the effort shifted from improving workers' moral conditions to enhance the allegiance between

285 Crawford, Margaret, Building the Workingman's Paradise: The Design of American Company Towns (London: Verso, 1995). 
employers and their employees. Under this reasoning, by assuming a larger degree of responsibility for the health and well-being of its workforce through welfare programs, the company would be rewarded by increased worker loyalty. On a practical level, Crawford connects this movement of corporate welfare with improvements such as lighting and safety in the workplace as well as programs to improve worker morale and financial self-improvement. These programs carefully avoided the rhetoric and actions of paternalism that could be associated with overt control. Crawford sees far less change in American industrial housing. While some companies adopted minor improvements, little innovation is evident until around 1910 when some started hiring professionals to design entire town landscapes. The progressive movement's main efforts centered on improvements to urban slums through political reform and improved housing design. ${ }^{286}$

Arnold A. Alanen traces the impact of this national discussion about corporate housing on the iron ranges of Lake Superior. ${ }^{287}$ Starting in 1844 on the Marquette Iron Range, many small mining companies attempted iron mining in the iron ranges of Michigan, Minnesota and Wisconsin. European immigrants far outnumbered American born residents in these towns. As the companies generally lacked significant capital, they typically built simple towns with few services and basic town planning methods. Hundreds of settlements spread across the ranges, the most common form being "company locations," where rows of ubiquitous houses with uniform design are built on a pre-platted orthogonal street layout featuring only simple community services. In some locations, immigrant labor constructed their own small communities, usually with low quality housing and unplanned layout. The financial panic of 1893 changed the

286 Crawford, Building the Workingman's Paradise, 46-6o. 287 Alanen, Arnold R., 1979: "The Planning of Company Communities in the Lake Superior Mining Region,” APA Journal, July 1979, 256-278. 
commercial climate dramatically by allowing large integrated companies to take over much of the ranges. Better capitalized, these companies quickly upgraded the living conditions on their properties as a strategy to attract and maintain a large, stable workforce.

Wary of the lessons of Pullman, stronger companies adopted the contemporary ideas of welfare capitalism that looked to play a co-operative role in miner's lives. In keeping with the national trends described above, these efforts avoided the appearance of paternalism and control. Some companies began to improve conditions with recreational facilities, urban improvements such as water and sewer systems, and beautification programs often involving extensive tree plantings. Some went as far so to hire professional architects and planners to lay out new towns that broke up the visual monotony of past towns, provided extensive services and encouraged community spirit and good living standards with social programs. These planners brought their own perception of worker needs to their designs rather than consulting with the workers. Towns such as Gwinn, Michigan, designed in 1906, and Morgan Park, Minnesota, designed in 1913, placed the iron ranges amongst the forerunners of new company town design.

Alanen emphasizes that the primary governing philosophy of mining companies was to fit town development within their entrepreneurial values. Where investment exceeded expectations or the anticipated benefits, plans were altered or abandoned altogether. The interests of the mining operation always came first.

American planners borrowed many ideas for planned communities originating in Europe. Kiruna, the settlement for the Swedish iron mining company LuossavaaraKiirunavaara $\mathrm{AB}$ (LKAB), is an example of a European planned company town in the 
Swedish Arctic. Much of the plans for Kiruna reflect the planned Lake Superior iron mining towns but differences between them speak to the European approach to managing workers and worker expectations. ${ }^{288}$ Groups staked claims in the area in the 1880 s and in the 1890 s, when the two largest claimants merged into LKAB, work began on a simple settlement and operation to test and open the iron field. Offering employment and connected to southern cities by rail, hundreds of people moved to the temporary settlement and established a crowded shanty town out of scrap and local materials. The Swedish government took an active interest in the region with aims to extend political influence there and accepted the land claims on the basis the company developed a sustainable settlement designed for families with adjoined company and government sections under the authority of a municipal community administration. From 1900, the company led the planning and construction of the two adjacent settlements and soon constructed a church, personage, fire station, hospital, water system, street lighting and a street car line. The settlements resemble the Lake Superior planned communities with their curvilinear streets and parks but are divergent because the company built more facilities for inhabitants, rather than help them build for themselves, and adopted this style of settlement earlier in the operation's development. With greater expectations for services and housing than in the US, Scandinavian workers would have viewed Longyear City negatively, encouraging action against the Arctic Coal Company.

In comparison, the Arctic Coal Company adopted almost no aspects of welfare capitalism and professional town planning practice in Longyear City. In line with Alanen's

288 Brunnström, Kiruna - A Swedish Mining City from the Turn of the Century. 
explanation of mining company behavior, community development there fell strictly within the bounds of the financial capacity and interest to do so. The Arctic Coal Company never made money and struggled with even proving that any company here could be profitable in the future. By Alanen's rationale, the company would not consider more sophisticated worker-company relations until that situation had been resolved.

Longyear City fell behind the contemporary American industrial towns because it made almost no headway in developing a community. Every aspect of the city emphasized its status as a functional camp. The Arctic Coal Company's commitment to its workforce went only as far as providing adequate food and housing and a marginally safe working environment. It provided no recreational facilities and no churches or even a religious figure. The Arctic climate prevented the possibility of tree plantings and the company undertook no beautifying programs. Enormous seasonal worker turnover with few returning workers meant that town inhabitants had little to no collective memory of the place. Very few families ever lived there and then only at the tail end of the company's existence, and no one owned their own house or land. The company never even divided the land into plots. Almost no one had any stake in the town as a community member. The concept of adopting welfare capitalist approaches made little sense in this type of settlement. This description fits with David Sugden's analysis of Spitsbergen that characterizes the archipelago in 1982 as a resource frontier on the periphery of Europe and Russia under Friedman's Core/Periphery model. ${ }^{289}$ Sudgen cites as evidence the region's dependence on a single economic resource with direct links to outside economic 'cores,' which is manifested in specialized towns that meet economic goals rather than

289 Sugden, Arctic and Antarctic, 285-286. 
sustainable ones and dominated by a transient, young, male social structure or workforce.

The company did emphasize the provision of a safe mining environment, mostly by minimizing the risk of coal dust explosion. This may indicate a limited recognition of contemporary American attitudes towards safe workplaces but the company also did this out of practical necessity. The deaths of miners in its works, it thought, would seriously damage its ability to hire good workers in the future and bring a loss in that year's investment in labor. ${ }^{290}$

\section{Contemporary American Industrial Housing Types}

This section makes a simple comparison between the types of houses adopted by the Arctic Coal Company and those of companies in America with particular attention to the coal fields of south-western Pennsylvania and West Virginia as they are a good representative of American approaches to coal mining towns and because the Arctic Coal Company drew some of its skilled workforce and one Superintendent from that region.

In 1920, Leifur Magnusson represented the Bureau of Labor Statistics of the US Department of Labor in a nationwide survey of company housing. ${ }^{291}$ He examined 216 companies, operating 423 establishments and employing 423,991 men, of which $34.4 \%$ lived in company homes. The study only looked at towns associated with mining and manufacturing, leaving aside several industry groups including those characterized by

290 Turner, Scott, "Mining in Spitsbergen," 1949, Encyclopedia Arctica, Michigan Technological University Archives and Copper Country Historical Collections, Scott Turner Collection (MS-018), box Z, folder 18 .

291 U.S. Dept. of Labor. Bureau of Labor Statistics. "Housing by Employers in the United States." Bulletin No. 263, Washington G.P.O., 1920 and Yost, Scott Turner, 10. 
seasonal work. Much of the study is statistical and calculates numerous spatial and financial variables by region and industry. It also asked employers why they adopted company housing and their satisfaction with the results. One limitation is the study's limited insight into the numbers of people living in each dwelling, which would further explain patterns of use and status.

Magnusson found that among the many reasons that companies provided housing, the primary one was that private interests would or could not provide it. Companies rarely built housing unless it was really necessary but most were satisfied with the results when they did. In response to a survey, companies placed their ability to secure better workers and to stabilize the workforce at the top of the list. The survey found only $1 / 7^{\text {th }}$ of company towns used town planning principles, the greater majority adopting the simplest grid design and repetitive housing forms. ${ }^{292}$ For decades prior to the study, company housing had witnessed improvements in quality, space and facilities for those living in them. A remark by an unnamed Superintendent of an isolated Pennsylvania mining town is revealing: "the time is gone when it is possible to pack foreigners in boxes for houses; we must supply them with clean, homelike quarters; for neatness of the town tends to cheerfulness and contentment of employees. The operator must consider the welfare of his workers." 293

Magnusson's survey of 32 companies controlling 114 establishments in the bituminous coal region of Pennsylvania and West Virginia showed semi-detached form dominating. $63.1 \%$ of housing was semi-detached while $33.2 \%$ were detached. Only $3.7 \%$ were row houses. The dominance of houses represents the companies' strong preference for 292 Ibid. 293 Ibid., 21. 
married employees. The houses typically featured two-story balloon frame construction, although one story houses were not uncommon. The region also had a range of rooms per dwelling and no one type dominated. Dwellings with three rooms were most prevalent, at $28.7 \%$, with significant numbers of houses of 4, 5 and 6 rooms. Few houses had two rooms and none had one. ${ }^{294}$

The study's use of the term 'dwelling' did not necessarily indicate accommodations for one employee or one family. Many families across the country augmented their income by providing food and lodging to boarders. One study on a small house in Michigan's Copper Country showed seventeen people living in a four room house with a 544 square foot floor space. ${ }^{295}$ Based on gross figures, Magnusson calculated 1.8 employees per dwelling in Pennsylvania and 2.5 in West Virginia. The survey lacked the data to calculate people per dwelling, which would be much higher when families were included.

Housing in this region remained exceptionally basic throughout the period of the Arctic Coal Company and beyond. The majority of houses for the general workforce featured clapboard or siding with no undersheathing, leaving them poorly insulated from the weather. Companies rarely painted, plastered or wallpapered the interior. The region's company housing featured a pronounced lack of modern conveniences. $49.8 \%$ had no conveniences at all, including water, sewage, gas, bath and electricity and $42.6 \%$ only

294 Ibid., 44.

295 Hoagland, Alison K., "The Boardinghouse Murders: Housing and the American ideals in Michigan's Copper Country In 1913," Perspectives in Vernacular Architecture: the Journal of the Vernacular Architecture, Forum 11 (Fall 2004), 2. 
had electricity. For those two classes, outside toilets was the norm. Of all industries, the American coal mining industry provided the least conveniences in its worker housing. ${ }^{296}$

The provision of housing and facilities related both to employment and racial hierarchies. Companies offered better housing as one way to attract and retain skilled workers and management. Companies typically had different housing standards for American and non-American workers, with Americans receiving higher standard facilities than foreigners and African Americans.

The coal companies of this region were slow to adopt the housing reforms advocated by the progressive movement. At first, many avoided larger beautification and recreational park programs and promoted simple gardening contests for town inhabitants. By 1915, the reforms started to be reflected in larger room sizes and increased rooms per dwellings. Increasingly, companies provided bath houses for employees, although most left that responsibility to the inhabitants. ${ }^{297}$

The poor quality housing and low investment by companies in Pennsylvania and West Virginia coal communities led historian Margaret Mulrooney to describe accommodations as houses, not homes. The houses, she argues, fell well short of providing a haven for the family and retreat from the world because they were generally crowded, uncomfortable, stuffy and poorly lit. ${ }^{298}$ Never-the-less, she identified a distinct

296 U.S. Dept. of Labor, "Housing by Employers in the United States," 44-47.

297 Mulrooney, Margaret M, A Legacy of Coal: The Coal Company Towns of Southwestern Pennsylvania, (Washington D.C.: Historic American Buildings Survey / Historic American Engineering Record, 1989), 19-23.

298 Ibid., 27. 
sense of community in these places well after most companies had closed operations, attributing this to the local sense of place and shared past coal mining experience.

Longyear City has much in common with contemporary company housing standards of Pennsylvania's and West Virginia's coal regions. Both show a preference for timber frame houses, although the Arctic Coal Company almost exclusively constructed single story dwellings and increasingly used concrete in later years. Both provided minimal facilities to the inhabitants with better facilities for the higher order employees. The Arctic Coal Company supplied slightly better services in this respect as they supplied all dwellings with electric light. Longyear City had unpaved dirt roads with no sidewalks, no sewage and no beautification and recreational parks.

In keeping with the national trend, the Arctic Coal Company built houses to attract workers and designed some specific housing forms to suit the particular type of workers it was looking for. The company maintained a hierarchy in the housing based both on company ranking and on racial and national characteristics. There, as in America, American workers received better treatment than employees of other origins.

Unlike in the coal regions of Pennsylvania and West Virginia, and for much of America, the Arctic Coal Company did not adopt a grid plan layout and did not construct houses of identical form. The layout of the town and the form of its structures represents an evolutionary approach to development, rather than a pre-determined, planned outcome. The most significant difference between the two regions is the size and type of housing constructed. Longyear City had dwellings both significantly smaller and of lower order than those found in Pennsylvania and West Virginia. The Arctic Coal Company provided a much greater proportion of bunk and boarding style houses, where almost every 
dwelling constructed fell within or below the lowest bracket of housing generally on offer on the bituminous coal fields. Based on the number of men dwellings in Longyear City could theoretically hold, Longyear City's greatest accommodation capacity was in two facilities with large rooms for sleeping up to 350 men. This housing was below the worst housing generally offered in Pennsylvania and West Virginia. Not much better were six structures with rooms for 4-10 men in bunk beds with room for around a maximum of 228 men. Better than both of these but still within the lowest bracket of housing are the three 1910 barracks and the adjacent family house built in 1912. This accommodation deterred most of the workers from forming an ongoing relationship with the company and settling in Longyear City whereas the American coalfields had much greater success in attracting and retaining its workforce.

Even the best houses of Longyear City fell well below comparable levels in Pennsylvania and West Virginia. The three cottages built at the north end of town for the families of the company's best workers each had a floor space of around 630 square feet. These provided a smaller living space than the average miner's cottage in Pennsylvania and West Virginia. Based on floor plans of three contemporary miner's dwellings from that region, most simple miner's dwellings had around 800 square feet. ${ }^{299}$ There, the houses for more upper level employees were generally larger by one or two rooms. One example of a standard six-room dwelling in a double- house built in 1900 had a floor space of just over 1000 square feet, larger than the incomplete Superintendent's house of the Arctic Coal Company, which had a proposed floor space of around 960 square feet. 300

299 Ibid., 40; 63; and 99.

300 Square footage for the Arctic Coal Company cottages and Superintendent's house calculated from measurements of the remains of the cottage's footprint made by MTU/LASHIPA in an archaeological survey of 2004. 
Longyear City held little resemblance with the coal miner's housing around Sheffield, where the majority of the company's British foremen and engineers originated. While the qualities of worker housing varied across regions, most coal company's built housing in attached rows of brick or stone from the mid-eighteenth century. ${ }^{301}$ Housing was often small and crowded, particularly in fast expanding mining areas including Sheffield, and typically lacked basic utilities, such as internal water and sewage, which only began to be installed in the early twentieth century. By the time of the Arctic Coal Company, the percentage of British miners in company houses was in decline and in 1913 represented only $12 \%$ of housing. ${ }^{302}$ The majority of miner's rented from non-company landlords and an increasing number owned their own homes with the assistance of building clubs and cooperative societies. While many British coal mining communities were isolated, the ones in Sheffield and nearby Rotherham existed within a diverse urban landscape which increased inhabitants' access to goods and freedom of movement.

\section{Comparison with the Kennecott Mill Town}

The Kennecott Mill Town offers a good opportunity for comparison as a contemporary and isolated mining camp existing in a cold northern climate. ${ }^{303}$ The Kennecott Mill Town Cultural Landscape Report divides the site's history into four phases: 1900-1908; 1908-1915; 1915-1938; 1938-1997. This section focuses primarily on the period of 19061915, which includes initial construction and the early maturing of the town site. After

301 Flinn, Michael W. The History of the British Coal Industry, Volume 2, 1700 - 1830: The Industrial Revolution (Oxford: Clarendon Press, 1984), 431.

302 Church, The History of the British Coal Industry, 599-614.

303 This section primarily uses the Cultural Landscape Report of the site as the basis for the majority of the historical outline: Cathy Gilbert, Paul White, and Anne Worthington, Cultural Landscape Report: Kennecott Mill Town (Copper Center: Wrangell-St. Elias National Park/Preserve, 2001). 
1915, the owners and developers of the town site reorganized the controlling company into a much larger public corporation, somewhat similar to the ownership change over Longyear City, which moved into the hands of a larger syndicate. This section reinterprets that timeframe into three phases that match local stages of construction to facilitate a more detailed view of the early expansion of the site: 1906-1908; 1909-1911; and 1912-1915. Co-incidentally, these phases exactly match those used for Longyear City.

The town stands around 2,00o feet above the Kennecott glacier on the western slope of Bonanza Ridge, which is on the south side of the Wrangell Mountains in south-central Alaska. The area has a long cold winter and a short, warm summer season. It has a mean annual temperature of $28.4^{\circ} \mathrm{F}$ with an annual rainfall average of 15.7 inches, placing the area within the definition of semi-desert. 304

Knowledge of copper ores in the region stretches back at least 500 years with exploitation of them by native inhabitants, probably ancestors to the modern Ahtna peoples living there today. The first survey of the area by European people took place in 1885 by a party led by Lt. Henry Allen and was further investigated by US Military expeditions of 1898-99. In 1899 and 1900, men identified as the McClellan Group identified and made claims on three major copper lodes. A young mining engineer, Stephen Birch, heard of the finds and drew on significant outside financial backing to form the Alaska Copper Company, which bought out claims and claim options over all lodes by 1902. Slowed by legal struggles over the action, the Alaska Copper Company used 1902-1905 to prospect the claims and attract additional capital to develop the region. It constructed no permanent structures in these years.

304 Encyclopedia Britannica, "Desert," Encyclopedia Britannica Home Page, <http://www.britannica.com> (31 March 2009). 
Birch recognized the need to develop a reliable method of transportation to the Alaskan coast, around 200 miles away, and successfully brought together the large financial interests capable of meeting that goal. Members of the Guggenheims, the House of Morgan, the Havemeyers, and Kuhn, Loeb and Co., formed the Alaska Syndicate, which re-organized the Alaska Copper Company, by then the Alaska Copper and Coal Company, into the Kennecott Mines Company with \$25 million dollars allocated for the construction of a railroad and mill. The syndicate owned the Alaska Steamship Company, which it used to transport copper ores to a Guggenheim-controlled smelter in Tacoma, Washington.

Efforts to develop mining operations on the 'Bonanza Lode' on Bonanza Ridge began in 1906. The company faced a difficult local terrain featuring steep inclines and little flat ground and chose the location of the mill town on the basis of the availability of suitable land, ability of a future rail line and aerial tramway to meet the site, access to drinking water from two creeks later called the National and Bonanza, and space to dispose of mill tailings. From 1906 to 1908, identified here as Phase 1, the Kennecott Mines Company built a small, simple construction camp and began to erect industrial facilities. The company placed most capital and effort on the structures associated with the industrial operations, leaving the settlement as a secondary feature. In 1906, a party sledded construction material to the site for the mill and aerial tramway and by 1907 had erected two log structures, the General Manager's office and a storage building. In 1908, the company built four more buildings: a small blacksmith shop, a 1-story post office/storage building, a 10,000 square foot sawmill and a 1 1/2 story bunkhouse. This study has not uncovered the internal layout of that bunkhouse. That year it began work on erecting the 
concentration mill and aerial tramway. Prior to 1908, workers may have been housed in canvas tents.

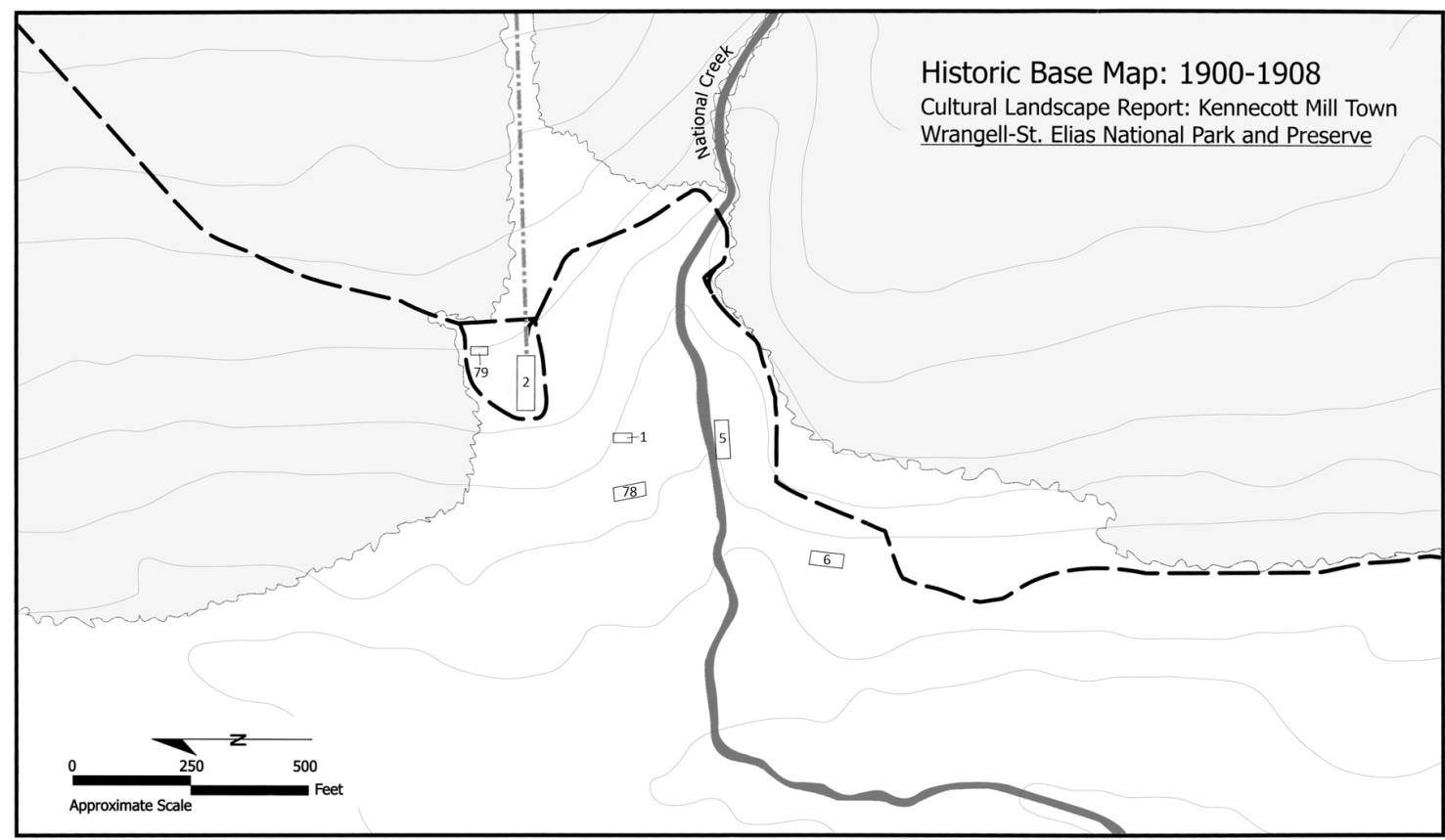

BUILDING LEGEND

$$
\begin{aligned}
& \text { Manager's Office } \\
& \text { Tram Terminus } \\
& \text { Bunkhouse } \\
& \text { Sawmill/Carpentry } \\
& \text { Warehouse } \\
& \text { Blacksmith }
\end{aligned}
$$

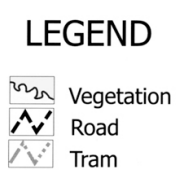

$\hat{\wedge}$ Road

Figure 5.12 Plan of the Kennecott Mill Town at the close of phase 1 in 1908. The Kennecott Mines Company concentrated more on building its industrial facilities than the town, which lay scattered on the landscape and conforming to local environmental features. Gilbert et. al., Cultural Landscape Report: Kennecott Mill Town, 21 (public domain) altered by C. Hartnell.

This phase of development shows several parallels with Phase 1 of Longyear City. Above all, the company emphasized the operational aspects of the enterprise over the settlement. The operational buildings including the General Manager's office and storage buildings stood before accommodations did, and when built, the settlement consisted of a simple barrack structure. 
As with the Arctic Coal Company, the Kennecott Mill Town's earliest manifestation matches local environmental conditions rather than a larger settlement plan. The Kennecott Mines Company made carefully planned choices on the town's location and the layout of critical technical infrastructure and devoted less time to laying out the town. The location of these structures, shown in Figure 5.12, fit local environmental conditions such as topography and the course of the National creek and lay in a scattered pattern rather than follow any town planning principles.

During the second development phase, 1909-1911, the Kennecott Mines Company undertook to expand the town. In 1908, the company hired L. A. Levensaler to map some nearby gold claims. In 1910, it instructed him to prepare the Bonanza and Jumbo lodes for mining. As work on the railway and concentration mill was still underway, he decided to concentrate on site improvements first. Like the Arctic Coal Company, the Kennecott Mines Company expanded the types of facilities available at the town with a more extensive range of accommodation, technical, storage and living facilities.

In 1910, Levensaler had a crib dam erected on the National River above the town that provided drinking water and electric power to the camp and mines, the same year the Arctic Coal Company's operations received power. He augmented the accommodations with a $2^{1 / 2}$ story bunkhouse, known as the East Bunkhouse, a $3^{1 / 2}$ story staff house for the upper staff, and a 1 1/2 story manager's house. Workers also erected a bunkhouse, mess hall and blacksmith shop above at the mine. Levensaler expanded the industrial facilities with an assay office, a storage building / company store and a powderhouse. The layout, design and color of these facilities reflected both the social status of the company and the functional needs of the operations. 
The East Bunkhouse provided much better living conditions than all bunkhouses at Longyear City. The first floor provided living facilities including washrooms, locker rooms, a reading room and a pool room. The second floor provided thirteen 83.5'sq. rooms attached to a central hallway, each accommodating either one or two to a room depending on rank. These rooms provided more space to the inhabitants and split them into smaller groups. ${ }^{305}$ This type of accommodation was best suited to single workers, forcing married employees to leave their families behind.

The company expanded its local food sources by erecting a dairy barn, providing a community garden and acquiring meat and vegetables from Chitina Valley residents. Those efforts only made a small impact on food needs and the company imported most of its food from elsewhere. Levensaler also upgraded general town facilities with pedestrian boardwalks, a fire hydrant system and some landscaping features.

This second phase of the Kennecott Mines Company's development largely resembles that of the Arctic Coal Company. Both companies broadened their industrial and settlement facilities at this time. Parallels exist with the worker housing, where the general workforce lived in bunkhouses, the upper staff lived together in a more spacious staffhouse, and the General Manager lived in his own accommodations. This restricted the option of bringing families only to upper employees.

One difference is that the Kennecott Mines Company erected two and three story structures whereas the Arctic Coal Company remained at one. Both the local climate and much larger investment capital allowed the Kennecott Mines Company to go further than

305 Plan of the East Bunkhouse at the Kennecott Mill Town, National Park Service, Wrangell-St. Elias National Park \& Preserve, 13 February, 2008, Drawing No. 190 / 80,103. 
the Arctic Coal Company in providing more facilities for local food production and procurement, better employee living and recreation facilities and more safety equipment.

Financial success prompted a third phase of development, 1912 -1915. In 1911, the Alaska Syndicate completed the Copper River and Northwestern railway between the Kennecott mines and the port of Cordova and soon afterwards, the Kennecott Mines Company completed the mill. By April, it sent out its first shipment of high grade copper ore with subsequent shipments each two weeks. The company boasted immediate profits and by 1912 had paid $\$ 3$ million in dividends. Further ore discoveries in the area matched the financial success, indicating a bright future for the enterprise.

The commercial success prompted further improvements at the settlement from 1912. The company made several improvements to its concentrating mill and technical system. It expanded the General Manager's office with a 1 1/2 story addition and the East Bunkhouse both in length and height. In 1915, the company completed work on a hospital and six small staff cottages. Company housing could not accommodate the full workforce of around 500 and the Kennecott Mines Company housed some workers in tents nearby.

The authors of the Cultural Landscape Report for the Kennecott Mill Town argue that the spatial organization of the town developed from the pattern established by 1908. The administrative and residential area developed around National Creek with the administrative functions located nearer the mill and aerial tramway. Warehouses and work shops stood around the rail line and the cottages ran in a line at the north end of town. Figure 5.13 shows that the town had begun to take a more formalized shape with 
buildings standing in rows but by no means followed a formal town plan such as the grid system.

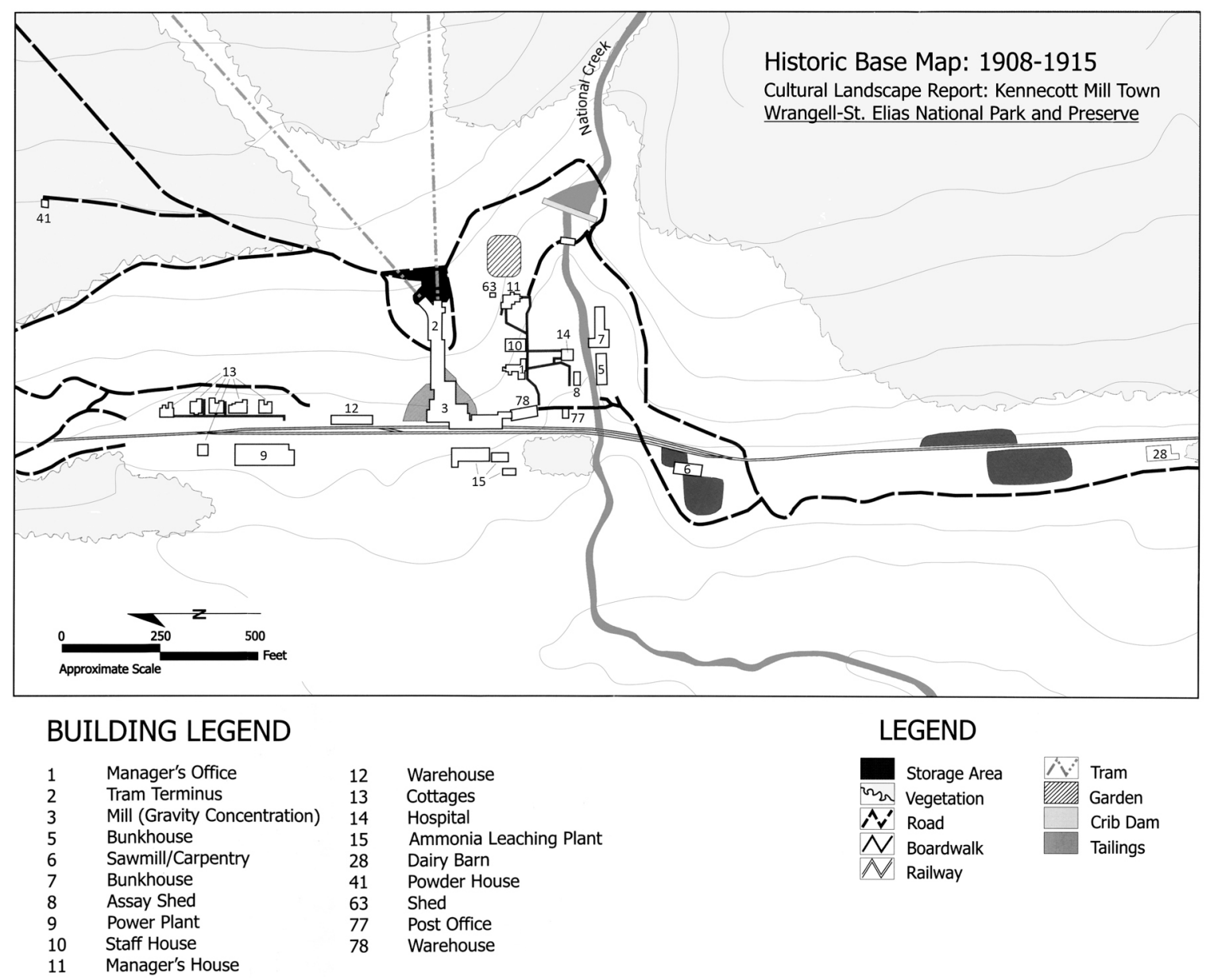

Figure 5.13 Plan of the Kennecott Mill Town at the close of phase 3 in 1915. Through phases two and three, the Kennecott Mines Company expanded its housing types and enhanced the settlement pattern of phase 1. Gilbert et al., Cultural Landscape Report: Kennecott Mill Town, 33 (public domain) altered by C. Hartnell.

This third phase again follows the broad pattern of development seen at the Arctic Coal Company. At Kennecott, as at Longyear City, the town now provided better facilities in the form of cottages for high-level employees to bring their families and live more independently from the rest of the workforce. The town developed towards a planned layout through a process of evolutionary expansion that built upon earlier patterns of 
development. The resources of the Kennecott works, though, allowed that company to provide better facilities than those at Longyear City even though its workforce was not much larger. While the head of the Arctic Coal Company turned down Scott Turner's proposal to construct a doctor's surgery, the Kennecott Mines Company proceeded with a hospital.

The Kennecott workforce, like that of the Arctic Coal Company, was highly transitory. Native born employees numbered around half of the workforce, followed by Scandinavians, then people from Canada, Britain and Slavic countries. The company employed some Japanese people for work in the cook houses and laundries. The Kennecott Mines Company took responsibility for housing its entire workforce and did so with all timber, balloon frame structures with the exception of using tents for excess workers. But the company always experienced dramatic worker turnover. Almost every year, numbers larger than the entire working force quit and required replacement. ${ }^{306}$

Broadly speaking, the Kennecott Mill Town shows an exceptionally similar pattern of development compared with Longyear City. That both have three identifiable periods of expansion of almost identical timeframes is a significant parallel alone. Beyond that, the Arctic Coal Company and the Kennecott Mines Company pursued a very similar development approach. In the earliest years, the companies invested most heavily in the industrial system while leaving the settlement as a secondary consideration. At that time, both towns featured simple accommodations and a limited breadth of structure types that lay scattered on the landscape with positioning that matched local environmental features. In the second phase, both companies invested in expanding the types of

306 Hovis, Logan, Mining Historian, National Parks Service, email correspondence, March 30-31 2009. 
structures to provide power, improve industrial function and expand worker accommodations. In the third phase, both again expanded the town facilities, including cottages for the most skilled workers and their families. The companies never implemented a formal town plan. Rather, they built upon an existing layout pattern that began by utilizing local environmental features, particularly topography, and later formalized those patterns.

Of particular interest is the reliance on bunkhouses at both operations. As argued above, bunkhouses lay at the low end of worker housing in typical bituminous coal towns of Pennsylvania and West Virginia, where companies preferred to attract married workers with single or double houses. Yet this form of accommodation is prevalent in settlements of American mining companies working in Alaska. This type of structure required less time and material to build than compared with building houses for the same number of people. The structures also take less space, which was particularly important at the Kennecott Mill Town. Bunkhouses and boarding houses are also more efficient to heat than collections of individual structures as they have a much smaller surface area to internal space ratio. At Kennecott, the use of multi-storied structures would have further retained heat as most warm air on the ground floor would pass through the above floors before being lost to the atmosphere.

Alaskan mining companies of the period commonly used bunkhouse accommodations. The later Kennecott operations built one more bunkhouse at the Kennecott Mill Town and constructed similar bunkhouses at its three mine sites. ${ }^{307}$ The Suntrana Mine in central Alaska, started in 1921 and soon the largest coal mining operation in the state, constructed at least two bunkhouses as part of its earliest development of the Suntrana

307 Hovis, Logan, email correspondence, March 30-31, 2009. 
Township. That mine attracted a predominantly single male workforce until it erected houses suited to families. ${ }^{308}$ By 1938, the Independence Mine, a gold mine in southcentral Alaska, had both houses and a three story bunkhouse. ${ }^{309}$ Other Alaskan mines including the Monarch and the Ruff \& Tuff also used bunkhouses. ${ }^{310}$

Governments and companies of other nations preferred multi-habitation structures for settlements in the Arctic. The Russian government favored apartment blocks of up to 5 stories in its Arctic region and Kiruna featured a mix of houses and compact apartment buildings. As with the Arctic Coal Company, the Russian government found poor housing and limited cultural amenities the main factors discouraging workers from moving into settlements. ${ }^{11}$ Russian settlements on Spitsbergen also used this type of housing ${ }^{312}$ as did other companies working on the Archipelago. ${ }^{13}$

The most noticeable difference between Longyear City and the Kennecott Mill Town is the superior form and facilities associated with the latter. Clearly the vast capital backing of the Kennecott mine enabled it to attempt a more sophisticated settlement but climate also played a significant role. Even from the beginning, the Kennecott Mines Company had better access to its mine than the Arctic Coal Company. It sledded some materials to

308 Buzzell, Rolfe G., Mining the Burning Hills: A History of Alaska's Suntrana Coal Mine and Townsite (Anchorage: Alaska Department of Natural Resources, 1984).

309 Photograph of the bunkhouse at the Independence Mine, Alaska's Digital Archives. Josette and William Stoll Papers, UAA-hmc-0236-s3a-84.

310 Based on search of 'Bunkhouse' at Alaska's Digital Archives website, <http://vilda.alaska.edu/> (March 30, 2009).

311 Armstrong et al., The Circumpolar North, 43.

312 Including Barentsburg, Pyramiden and Grumantbyen.

313 Sveagruvan, the Swedish company AB Isfjorden-Belsund's settlement at Braganza Bay featured bunkhouses for its workers. Avango, Sveagruvan: Svensk Gruvhantering Mellan Industri, Diplomati Och Geovetenskap, 217-243. 
the site over the winter months and had a longer and warmer summer for construction. This placed the company under less time pressure than the Arctic Coal Company, which looked to ship building supplies and erect buildings within a single summer season. Once its railway was completed, Kennecott had an all-year access to the rest of the US, further easing that pressure. The difference of capital and climate helps explain why the Kennecott Mines Company could attempt two and three story structures and better community facilities while the Arctic Coal Company almost exclusively stayed with single story structures.

\section{Conclusions}

While Ayer and Longyear afforded their managers limited capital and labor for the construction of Longyear City, the management did what they could to use buildings as tools to strengthen the network and defend it against dislocation from labor resistance. Ultimately, though, they only made limited progress and the threat of worker resistance and workforce transience almost always remained. Furthermore, basic housing, the almost total lack of beautification features, recreational facilities, general lack of private space and lack of private ownership of housing, left Longyear City a medium sized camp, not a community.

The Arctic Coal Company's development of its settlement matches the broad periodization and evolutionary development pattern of its technical system, where management gradually expanded existing patterns rather than adopt formal town planning methods. The evolution of the town shows evidence of management responding to different actants working upon the network. Operational pressures included the need to prioritize capital and effort available between the operations and the settlement, 
where the settlement received secondary attention. Management responded by building simple structures that could be erected quickly and cheaply, evidenced by the company's use of single story gable structures and its avoidance of underground basements that would confront complications with permafrost. They also made small adaptations to the Arctic climate and Spitsbergen's isolation by triple-sheathing at least some of its frame housing to better insulate them and protect them from strong winds and increasingly used concrete as a construction material that drew on local materials, required less space on transporting ships and cost less.

Above all other actants, management paid greatest attention to the issue of labor in building housing as it continually attempted to provide facilities that created space for the operational hierarchy they desired while working against the threat of labor resistance. In 1908, housing at Longyear City provided the simplest manifestation of hierarchy with almost no space for middle management but from that time forward, the company concentrated on building facilities for a variety of management levels within an ethnic context. This helped strengthen the network as it helped enroll the skilled workers needed at the operations and emphasized the power structure of the operations used to control the workforce. Housing for unskilled workers undermined these gains as it held the majority of people in crowded, mass accommodations that made them harder to control and more inclined to act against the company. While management recognized the negative impact of mass accommodations, and built a few better structures to counter that, it largely failed to overcome the problem. One recurring strategy to introduce a boarding house system run by others almost totally failed to materialize and the company remained stuck with a responsibility it did not want and struggled to handle. 
Comparative analysis shows that the central characteristics of contemporary American housing reform movements and company housing methods had little impact on the Arctic Coal Company's approach to its settlement. The Arctic Coal Company did not utilize any beautification strategy nor did it undertake a 'capitalist welfare' strategy with its workforce. The company's approach does match Alanen's assertion that company housing fit within the commercial interests of the company involved, which in this case meant lowering investment to a minimum. The company's attitude towards providing a safe working environment may related to the growing assumption of responsibility for safe workplaces by American companies.

The housing seen in Longyear City fell well below the contemporary standards for company housing in the bituminous coal fields of Pennsylvania and West Virginia, which itself sat below the standards across most of the US. Company towns there used a high proportion of single and double houses, which promoted settlement by married couples. There, the amount of space per worker reached levels well above those at Longyear City. Even housing for married couples on Spitsbergen provided less space than an average miner's house in Pennsylvania and West Virginia and the planned Superintendent's house would have provided less space than a skilled worker on the bituminous fields. Several aspects of these two regions are common. At both, the use of timber frame structures prevailed over other construction forms. Each region rarely provided housing facilities such as utilities and internal toilets and both used inadequate construction to insulate inhabitants from the climate.

Longyear City compares well with the Kennecott Mill Town, in south-central Alaska. Like Longyear City, it developed in phases of construction in an evolutionary fashion that built upon earlier layout patterns. Initial decisions over the layout of each followed local 
environmental conditions including topography and the location of water, rather than formal town planning methods. In later years, the controlling company began formalizing the form of both by locating new construction in rows adjacent existing structures. The isolation and climate of both camps, and the strategy towards housing the workforce, promoted the use of a predominantly single male workforce that remained highly transitory. Kennecott Mines Company's much larger capital budget year-round access to its mines allowed it to provide better facilities than the Arctic Coal Company, in the form of larger quarters and better community facilities. Even still, both faced the destabilizing reality of a heavily transient workforce.

While companies in the continental US used few bunkhouses in their settlements, the housing type was much more common in the Arctic. Settlements across Alaska, Russia, Spitsbergen, and to at least some extent Scandinavia, commonly featured bunkhouses or apartment buildings, perhaps because they better retained heat in a cold Arctic climate, were quicker to build and used less construction material. Some, such as those at Kennecott, also improved living conditions as they provided multiple facilities under one roof which reduced the need to interact with the outside environment. 


\section{CHAPTER 6}

\section{Comparison of the Arctic Coal Company with Typical American Mining Practice Overseas}

\section{Introduction}

Spitsbergen's extreme location marks the Arctic Coal Company's attempt to mine there as historically unusual but contemporaries would have found nothing unique in the act of mining under difficult circumstances. American mining engineers attempted to exploit all kinds of landscapes around the world and sometimes under conditions that people found hard to bear. Chapter Four showed that the Arctic Coal Company adopted standard technologies in its operations and did not need to develop new equipment to match the high-Arctic environment. This chapter compares the Arctic Coal Company's choices for sourcing technologies, skilled workers and capital with typical American practice and explains findings through environmental, technical and social factors. A desktop survey establishes if American companies' choices of where to obtain equipment, capital and skilled labor followed a pattern and how it was manifested across the world. Histories of technology transfer, which assess the reasons why cultures adopt some technologies over others, form a backdrop to analysis of American company behavior and the question of why the Arctic Coal Company fits or diverges from that pattern.

By examining the sources of people, capital and equipment alone, the chapter simplifies the complex realities of modern mining because technology suppliers can be located in different places to where technologies were developed or adapted. The constant flow of people, ideas, machinery and capital across the world characterized an increasingly 
global mining industry from at least the mid-nineteenth century. Diane Menghetti points to the blurring of lines between invention, innovation and adaptation in Australia, where Australian, British, American and other peoples, capital, technologies and ideas contributed to the adaptation of existing technologies and the development of new ones. 314 The same is certainly true for America, a land filled with immigrants, ideas and technologies from all over the world, where multi-national relationships leave definitions of strict national origins irrelevant. The distinction is especially important for American mining equipment. According to mining historian Roger Burt, Americans were more adopters and adapters, rather than innovators in the nineteenth to early-twentieth centuries. ${ }^{315}$ He argues that cultural conservatism and rich, easily worked mineral deposits tempered the need for innovation in American mining, which consistently lagged behind Europe. Americans, however, successfully adapted many European technologies to better suit American conditions and preferences. In this way, the light European stamping technologies of the mid-nineteenth century became larger, heavier and faster operating in America. In other words, the European stamps were 'Americanized.'

\section{Methods}

A contemporaneous survey of American companies working overseas, based on descriptions in mining journals, historical literature and historic studies, provides the basis for characterizing the location of American mining companies across the world and their pattern to importing technologies. The comparison necessarily rests at a basic level

314 Menghetti, Diane, 2005. "Invention and Innovation in the Australian Non-Ferrous Mining Industry: Whose Technology?" Australian Economic History Review, 45(2):204-219.

315 Burt, Roger, "Innovation or Imitation? Technological Dependency in the American Nonferrous Mining industry." Technology and Culture, 41 (2000):321-347. 
because of the variety of minerals mined and vast numbers of American companies under consideration. All types of mining are considered through US history up to the outbreak of World War I in 1914, including but not limited to coal, non-ferrous metals, iron, oil and precious stones.

Excluding Canada and Mexico, where many American firms invested, evidence exists for at least one hundred American mining companies working overseas. Exact numbers are difficult to calculate given the meager references made to some companies, which may or may not have even started mining, and the real possibility that minor companies changed names, leaving the impression in the sources that two companies existed. The study referenced readily available secondary sources, particularly using American mining journals, ${ }^{316}$ US government reports and books and articles on individual mines and mining regions. The information retrieved on individual operations varies considerably from simply a company name and location to detailed accounts.

\section{Overview of Approaches used by the Arctic Coal Company}

Under its first three General Managers to mid-1911, William Munroe, John Gibson and Frederick Burrall, the Arctic Coal Company adopted English mining approaches, employed English mine bosses and purchased predominantly British and European manufactured equipment. From 1905, the company looked to Bert Mangham lead the development of the mine, the employment of foremen and skilled miners and to choose mining equipment. He chose to use the mining approach, people and machinery of the

316 In particular, the study referenced The Mining and Engineering Journal, Institute of Mining and Metallurgical Transactions, Mining and Scientific Press and the Engineering and Mining Journal. 
region he came from, the coal mining and manufacturing districts around Sheffield, England.

Following the English miners' advice, the Arctic Coal Company designed its underground workings for longwall mining. ${ }^{317}$ In the longwall method, miners extract coal along an extended coal face, gradually moving the whole wall forward while abandoning extracted areas behind them to collapse, often after filling it with waste material. The method has the advantage of extracting all coal in an area but took an extended time to prepare and required co-coordinating a team of people under a supervisor. ${ }^{318}$ Inside the mine, the company used rail cars purchased from a manufacturer in Sheffield and upon electrifying the operations in 1910, purchased English mechanical coal mining equipment. ${ }^{19}$ While an American always headed the Company, English men directed work in the mine. Bert Mangham brought several mining engineers from Rotherham, adjacent Sheffield, to design and direct the opening of the Arctic Coal Company's mine and reflected "I feel sure in saying that men from the Rotherham area were the Pioneers of Spitsbergen Mining.” ${ }^{200}$

Even for equipment outside the mine in Longyear Valley, the Arctic Coal Company generally chose to purchase from English or European manufacturers. Adolf Bleichert \& Co. of Leipzig Germany, designed, manufactured and directed the installation of the

317 DePasqual, "Winning Coal at $78^{\circ}$ North."

318 Daunton, M.J. 1981. "Down the Pit: Work in the Great Northern and South Wales Coalfields, 1870-1914." The Economic History Review, New Series 34(4):581-582.

319 The company bought its coal cars from the Hadfield Steel Foundry Co. Ltd., of Sheffield, and two coal cutting machines from Diamond Coal Cutter Co., of Wakefield, England.

320 Bertrand Mangham, The First Mining in Spitsbergen, Unpublished notes, date unknown, transcribed by G. A. Mangham in 1993, 10. 
company's aerial tramway system. The company chose predominantly English made equipment for its 1910 powerhouse, also purchasing two boilers from a Norwegian company. ${ }^{321}$ The American General Managers made decisions on the aerial tramway and powerhouse technologies based on assessments of quality and price. The company's ship came from Norway and much of the food, timber and basic equipment came from either Norway or England. The company's Norwegain shareholders supported access to much of the Norwegian goods, particularly food and timber, through their knowledge of the local markets and peoples. In contrast, the company purchased little from American manufacturers, the most significant item being a crane for coal loading from a New York manufacturer. ${ }^{322}$

Under Scott Turner, beginning in late-1911, the company moved towards using predominantly American management, mining methods and manufactured equipment. Turner saw the American mining sector as superior to those of other nations and viewed the change as a natural improvement. His letters and reports show that he believed American mining men to be superior to others and attributed improvements in the operations to their presence. In 1914 he wrote "For the first time in the history of the Company, the administration of affairs was entirely in the hands of Americans on Spitsbergen, and this change from the former English regime has been most satisfactory.” ${ }^{323}$ He also viewed American machinery to be almost always more reliable

321 Hartnell, Cameron, 'Arctic Coal Company Powerhouse' inventory card, in Hartnell, Cameron, Seth DePasqual and Patrick Martin Heritage Survey of the Arctic Coal Company, Svalbard: Svalbard's Environmental Protection Fund Final Report, (Houghton, MI: Michigan Technological University, 2008).

322 A 1 5/8 Cubic Yard C.S. Steel Travelling Excavator, from the Hayward Company of New York. 323 Arctic Coal Company Annual Report for the year from September 1, 1913 to May 31, 1914, Michigan Technological University Archives and Copper Country Historical Collections, Longyear Spitsbergen Collection (MS-031), box 4, folder 15. 
than most foreign competitors and American mining methods to be more efficient and cost effective than the alternatives. On finding that he could have American equipment delivered to Spitsbergen as cheaply as European alternatives, he felt little compulsion to remain with the British mining system he had inherited. 324

At first Turner simply added the presence of American men, methods and equipment while continuing to use existing systems. In 1912, he decided to introduce the room-andpillar coal extraction method into Mine 1 and developed a new mine across the valley, Mine 2, along the same lines. The room-and-pillar method featured smaller teams of workers that worked an entry off a main heading and extract coal in a way that leaves a room supported by walls of coal. Miners may later remove the remaining coal, allowing that part of the mine to collapse. ${ }^{25}$ American mining companies adopted the room-andpillar method from the British, which remained the dominant approach at the time of the Arctic Coal Company. ${ }^{26}$ The British used both longwall and room-and-pillar methods, and their associated methods. ${ }^{327}$ In 1912, Turner purchased both American and English manufactured mining equipment and used both American and English mine foremen under the direction of Bert Mangham. Turner shifted further towards American sources in 1913. That year he fired Bert Mangham, the English Winter Superintendent, and replaced him with an American coal mining engineer, Frank Dalburg, who was experienced in the American preferred room and pillar approach. He expanded the

324 Letter from Scott Turner, General Manager of the Arctic Coal Company to the Arctic Coal Company, April 30, 1912, Michigan Technological University Archives and Copper Country Historical Collections, Longyear Spitsbergen Collection (MS-031), box 5, folder 3 .

325 Daunton, "Down the Pit," 580-582.

326 Seltzer, Curtis, Fire in the Hole: Miners and Managers in the American Coal Industry (Lexington, Kentucky: The University Press of Kentucky, 1985), 12.

327 Daunton, "Down the Pit." 
American management force both inside and outside the mine and looked predominantly at American manufacturers to supply infrastructure development. He also largely abandoned Sheffield as a British base, preferring Newcastle and London. The Newcastle region predominantly used the bord-and-pillar method, similar to the roomand-pillar approach. ${ }^{228}$

Turner also turned to American sources for aspects of the organization outside the mine. He looked into purchasing a broad array of more simple goods including condensed milk from the US, believing it may be cheaper but found otherwise. He placed all American made equipment in the powerhouse expansion save a de-oiler from England ${ }^{329}$ and purchased other equipment including a second crane and a mine hoist from the US. Longyear also purchased the second company ship from a merchant in Canada. Turner never turned away completely from English and European equipment and methods, he only went as far as was practical. While he successfully introduced the room-and-pillar approach in a section of mine 1 , that mine mostly continued to operate under the existing longwall method, which had a longwall mining layout and equipment. Figure 6.1 shows the use of both mining methods in mine 1 at the close of operations.

328 Daunton, "Down the Pit," 578-597.

329 Hartnell et al., 'Arctic Coal Company Powerhouse' inventory card. 


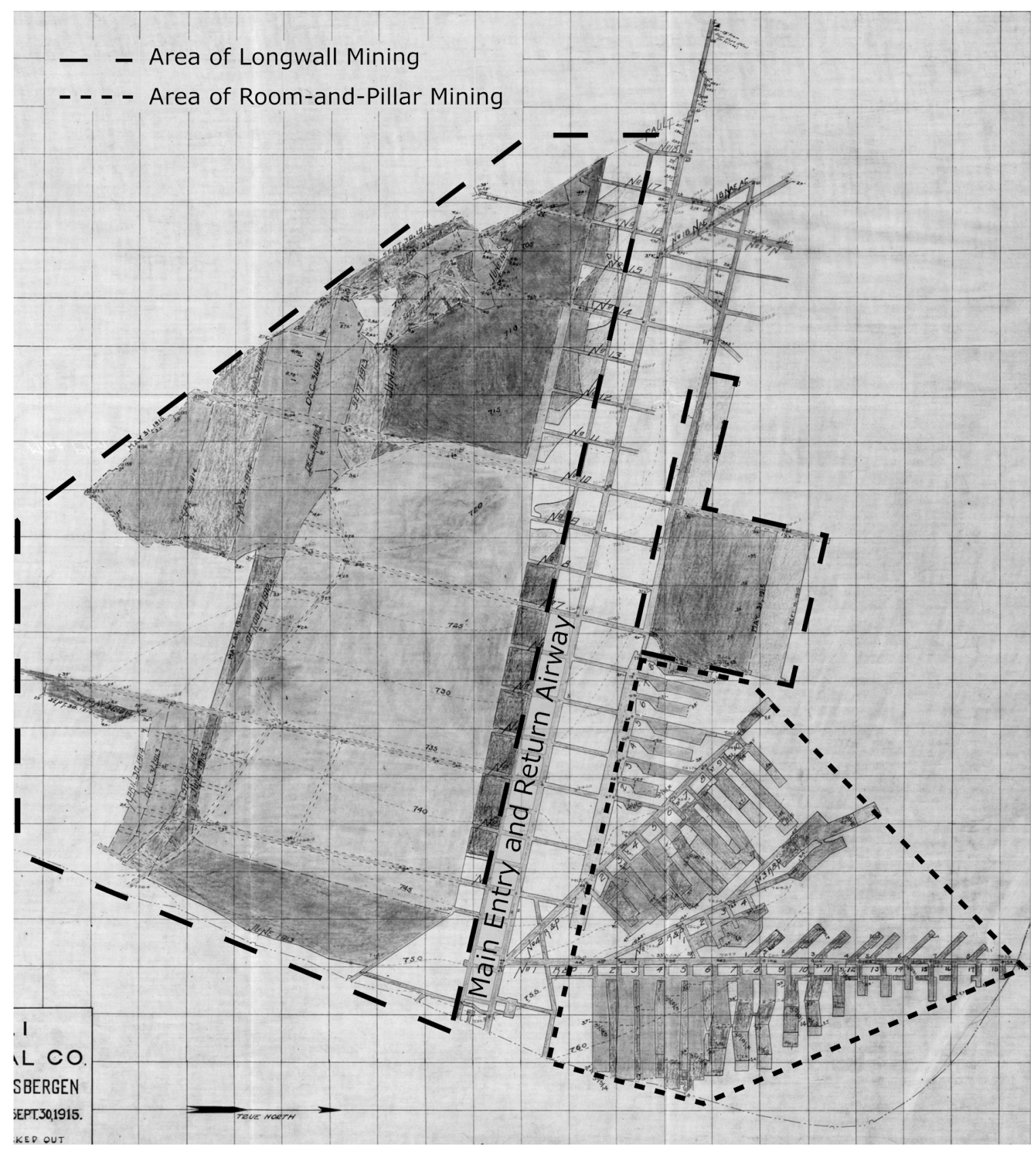

Figure 6.01 Plan of ACC mine 1, September 30, 1915. Blueprint altered by author. The plan shows the final state of the mine at the point of sale in 1916. Two different dashed lines indicate areas of Longwall mining, preferred in Sheffield, England, and the room and pillar method, preferred in the US. Michigan Technological University Archives and Copper Country Historical Collections, Michigan Technological University, Keweenaw Digital Archives, MSo18-Z-02-01. 


\section{The Pattern of American Mining Companies Overseas}

\section{Two Major Elements of American Mining Adopted Overseas}

American companies overseas turned to American sources in part because it had a strong mining sector that led the world in different aspects of mineral extraction. It was rational for companies to use workers, methods and equipment that they were familiar with and which compared favorably with alternatives. Two important historic facets of American mining are particularly relevant to efforts overseas, the California gold mill and the Porphyry copper mining sector. Gold mines, often associated with silver, represented the most common operation overseas and copper mining attracted the largest capital investment of any extracted mineral.

\section{The California Gold Mill}

This study identified eighteen American operations outside North America before World War I primarily concerned with gold mining, and twenty five primarily mining silver, together comprising the largest number of operations of any non-domestic American mining sector. The information on these operations, while inconsistent, shows them to be small to medium in size, up to $\$ 5,000,000$ capitalization, that generally existed independently from companies in the US. The historical data also presents a strong pattern of adoption of American manufactured milling machinery associated with the California Gold Mill.

The establishment of a distinctive ‘American’ approach to gold milling began developing soon after the California gold rush in $1849,{ }^{330}$ when hard rock and placer mining drew on

330 The first stamp mill in California was built in 1850-51. Ed. B. Preston, California Gold Mill Practices, California State Mining Bureau Bulletin No. 6. (Sacramento: A. J. Johnston, 1895), 7. 
well-known historic European and Mexican mining and milling methods. As the milling process is often closely associated with a gold mine's profitability, Americans continually looked to improve the process and they quickly adapted and improved the technologies, 'Americanizing' the process and over doubling gold recovery rates. Ed Preston neatly summed up the advancement of milling technology, culminating in the 'California gold mill' form, in 1895:

"While the stamp-mill itself had been used for crushing ores long before the discovery of gold in California, since that time it has been greatly improved in detail, and its capacity and efficiency increased, hence what is now known as the "California gold mill" is a very different affair from the clumsy mills first used for crushing quartz in this State. The California gold-milling processes and the California millmen are, as a result, finding due recognition outside of their own immediate field of operation, as evidenced by the increasing outside and foreign demand for our men and milling machinery". ${ }^{331}$

Since both gold and silver freely amalgamate with mercury, and as gold and silver often occur together, American miners regularly adopted the California gold mill for both gold and silver mines. ${ }^{332}$ Furthermore, the improvements in stamping technologies associated with the mill were applicable to crushing other hard rock ores, making the California gold mill a pivotal part of American milling advancement.

While regionalized and subject to different environmental and economical forces, the California gold mill model represented a fairly consistent collection of technologies set in series. Of particular importance was the use of stamps to reduce gold ores before concentration. While European mills had used stamps for centuries, the California gold mill involved the use of heavier, more powerful stamps. Mill constructors commonly set the mill against a slope, giving the structure a stepped appearance and allowing

331 Preston, 1895, 83.

332 Quivik, Fred, 2003. "Gold and Tailings: The Standard Mill at Bodie, California." IA, The Journal of the Society for Industrial Archaeology, 29(2):6. 
operators to use gravity to move ores through the milling process. Ores were most commonly concentrated through the combination of amalgamation and gravity concentration or amalgamation and cyanidation. 333

Surrounding improvements to the California gold mill were the maturity of the American gold and related metals mining sector. Local mining skill increased through practical experience and the establishment of professional mining and engineering schools such as Stanford. ${ }^{334}$ An actively collaborative mining community emerged that promoted technological improvement, the diffusion of ideas, and worked as a support mechanism to the entire industry. ${ }^{335}$ Extensive publication on milling methods and improvements in government documents, technical journals and local newspapers disseminated ideas to a wide American audience and the formation of 'discussion clubs' and the movement of skilled tradesmen were also pivotal in diffusing technical ideas. American companies came to manufacture all aspects of gold milling equipment associated with the California Gold Mill and adapted them into distinctive American forms.

By late in the nineteenth century, America could boast a very strong domestic gold mining industry capable of facilitating all aspects of gold and silver hard rock mining, which operations overseas could easily draw on for all their needs. And they did. This study has found extensive use of American milling machinery by American companies overseas, the great majority of which likely followed the California gold mill model. The historical record repeatedly describes the use of machinery from major manufacturers

333 White, Paul et al. Skidoo Mine, Death Valley National Park, HAER No. CA-290,

(Washington D.C.: Historic American Engineering Record, 2001), 4-14.

334 Spence, Clark C., Mining Engineers and the American West: The Lace-Boot Brigade, 18491933 (New Haven: Yale University Press, 1970).

335 White, Paul et al. Skidoo Mine, Death Valley National Park, 11. 
such as Fraser \& Chalmers, Union and Hendy wherever Americans are mining and milling these ores. This study has found no evidence suggesting that any American gold or silver mining operation overseas deviated from this milling approach.

\section{The American Copper Industry}

After 1869, the American copper mining industry experienced an accelerated growth based on US tariffs on copper imports, expanding operations in Michigan's Copper Country and the discovery and development of large copper ore fields particularly in Montana and Arizona. While American copper companies grew internally, the greatest growth came from mergers that allowed vertical and horizontal integration. Companies like Anaconda, originally of Butte, Montana, used mergers as a strategy to help control fluctuating copper markets and price volatility. Concurrently, American companies faced increasingly lower grade ores and needed to develop larger operations to work them profitably. 336

The industry first developed the techniques to work low-grade porphyry copper ores in Arizona at the end of the nineteenth century. Porphyry copper ore bodies hold roughly $3 \%$ or less copper content and require sophisticated concentration technologies to produce commercial grade copper. While Daniel C. Jackling is the most noted figure in developing the approach, his efforts came after other companies had already begun to move in that direction. Copper production in Arizona began in the mid-1880s under traditional underground mining techniques but soon some companies adapted to low copper prices and low grade ores by introducing mass mining and innovative smelting

336 Schmitz, Christopher, 1986. "The Rise of Big Business in the World Copper Industry 1870 1930." Economic History Review, 2nd ser. 39(3):392-410. 
techniques. From 1896, James Colquhoun developed a pilot plant and later a full scale plant for mining and concentrating ores of above $3 \% .337$

In 1899, Jackling and Robert C. Gemmell made a thorough examination of mining claims in Bingham Canyon. Finding an abundance of $2 \%$ ores, the men recommended open pit mining using steam shovels and specialized concentrating and smelting technologies. With extensive investment capital from the Guggenheims and others, Jackling led the incorporation of the Utah Copper Company in 1903 and in 1905 installed a pilot plant for mining and milling porphyry ores. By 1908, the company had transferred to full operations, finding spectacular financial and technical success. Jackling adopted many of the mining approaches innovated on Minnesota's Mesabi iron range, which combined advanced blasting techniques and non-selective mining with steam shovel and railway transportation. Soon other engineers enhanced Jackling's approach by adopting the flotation concentration technique, first used in the US in 1912, which enabled companies to work copper ore below $1 \%$ concentration. ${ }^{338}$

The success of the porphyry mining approach led the Guggenheims and others to pursue other porphyry ore bodies. 339 Soon, porphyry mining dominated western copper mining and huge American corporations began introducing it to the enormous known ore bodies of Mexico, Chile and Peru, particularly after the introduction of flotation concentration. The Guggenheims invested heavily in the Chile Copper Company, which by 1920 had a market capitalization of $\$ 135,000,000$. The company worked the Chuquicamata field,

337 Hyde, Charles K., Copper for America: The United States Copper Industry from Colonial Times to the 1990s (Tucson: The University of Arizona Press, 1998), 129-139.

338 Ibid., 139-142.

339 O'Brien, Thomas F., 1989. "Rich beyond the Dreams of Avarice: The Guggenheims in Chile," The Business History Review 63(1):122-159. 
then the largest developed ore body in the world, largely along the lines used at Bingham Canyon and with American engineers and American equipment. ${ }^{340}$ The Kennecott Copper Company, with the Guggenheims also substantial investors, purchased the Braden Copper Company that controlled the El Teniente mine at Sewell, Chile, in 1906 and developed that ore body into a huge operation. ${ }^{341}$ The Anaconda Company invested \$50,000,00o into the Andean Copper Mining Company, which worked the Potrerillos mine in Chile. The Cerro de Pasco Copper Company invested in the most expensive copper mining operation in history to date in Peru, featuring open pit copper mining, three coal mines and rail line construction, ${ }^{342}$ almost exclusively purchasing its equipment and technology from the United States. As one contemporary source put it, "the whole Cerro de Pasco district is testimony to the supremacy of American mining machinery." 343

All these large-scale companies adopted American capital and American technology. Combined, the mines made copper the largest sector of American foreign mining investment and the mechanism for enormous movements of American business and management techniques, people, capital and equipment overseas.

340 Weed, Walter Harvey, Mines Register: Successor to the Mines Handbook and the Copper Handbook, Describing the Non-ferrous Metal Mining Companies in the Western Hemisphere (NY: W. H. Weed, 1920), 1779-1783.

341 Klubock, Thomas Miller, Contested Communities: Class, Gender, and Politics in Chile's El Teniente Copper Mine, 1904 - 1951 (Durham: Duke University Press. 1998).

342 Weed, Mines Register.

343 "Copper Mining in Peru: Supremacy of American Machinery." Mining Science, 57 (8 1908):204. 


\section{American Mining Companies in the Americas}

Mira Wilkins' economic history of American enterprises up to World War I describes the distribution and size of mining companies working outside the US, including the changing distribution of American direct investment in all industries overseas and the regional character of those businesses. 344 Table 6.1 shows the change in direct investments in mining and smelting compared with total investment over the period. Mining and smelting had enormous national importance as the largest single investment sector for American companies overseas in the study period but companies had an overwhelming preference for mining in the Americas over elsewhere in the world, which garnered only $1.7 \%$ of the capital invested in the sector.

\begin{tabular}{|c|c|c|c|c|c|c|}
\hline \multirow{3}{*}{$\begin{array}{l}\text { Country or } \\
\text { Region } \\
\text { Mexico }\end{array}$} & \multicolumn{3}{|c|}{ Mining and Smelting } & \multicolumn{3}{|c|}{ Total Direct Investments } \\
\hline & $\mathbf{1 8 9 7}$ & 1908 & 1914 & $\mathbf{1 8 9 7}$ & 1908 & 1914 \\
\hline & 68 & 234 & 302 & 200 & 416 & 587 \\
\hline $\begin{array}{l}\text { Canada and } \\
\text { Newfoundland }\end{array}$ & 55 & 136 & 159 & 160 & 405 & 618 \\
\hline $\begin{array}{l}\text { Cuba and other } \\
\text { West Indies }\end{array}$ & 3 & 6 & 15 & 49 & 196 & 281 \\
\hline Central America & 2 & 10 & 11 & 21 & 38 & 90 \\
\hline
\end{tabular}

344 Wilkins estimates that in 1914 the book value of US direct investment in foreign mining was $\$ 720$ million. The manufacturing sector was the second largest sector at $\$ 478$ million. Wilkins, Mira, The Emergence of Multinational Enterprise: American Business Abroad from the Colonial Era to 1914 (Cambridge, Massachusetts: Harvard University Press, 1970), 206. 


\begin{tabular}{|l|c|c|c|c|c|c|}
\hline South America & 6 & 53 & 221 & 38 & 104 & 323 \\
\hline Rest of the World & - & 6 & 12 & 167 & 479 & 753 \\
\hline
\end{tabular}

Table 6.1 Estimates of US direct foreign investment for the years 1897, 1908 and 1914 (book value in millions of US dollars). From Wilkins, Mira, 1970, p110, who cites Lewis, Cleona. America's Stake in International Investment (Washington, D.C.: Brookings Institution, 1938).

\section{American Mining in Canada}

America's northern neighbor offered a friendly investment atmosphere coupled with enormous opportunities in mineral extraction. Canadian mining remained the second largest sector of US direct investment until just before World War I when South America took its place. America's mining relationship with Canada extends at least as far back as the 1840 , when prospectors looked for copper ores around Lake Superior and gold in British Columbia. The mining companies that emerged on the north side of Lake Superior drew on the mining methods at use on the American side to the south. The powerful American copper mining industry continued to play a leading role in the Canadian copper fields for many years, notably in its contribution to opening up the large nickel-copper fields in Sudbury, Ontario and the copper fields of Flin Flon, Manitoba. In the Fraser River gold rush of 1858 in British Columbia, an estimated 30,000 prospectors from California poured into the region. They brought the skills and technologies of the California gold fields with them. Some continued to prospect in other areas of Canada, some settled and others returned home or moved on to the next rush. 345

345 Mouat, Jeremy, Metal Mining in Canada, 1840-1950 (Ottawa, Canada: National Museum of Science and Technology, 2000), 34. 
From around 1870, the Canadian mining industry matured under the guidance of government policy that promoted industrialization, the local manufacture of American goods and improved mining education. From the formation of the unified dominion of Canada in 1867, and with an 1879 national policy that endorsed industrialization, Canada pursued economic policies aimed to encourage investment that would expand domestic industrial capabilities and enable it to compete internationally in sophisticated industries. Unlike most countries in the Americas, Canada had political and economic strength to support these goals. The government used tariffs, policies on patent rights and other mechanisms at its disposal to develop an economic environment favorable to manufacturing American goods in Canada. The policies were successful and by 1912, around two hundred branch factories of American companies produced their goods in Canada, including much of the mining equipment sold there. 346

As mining became more sophisticated in the late-nineteenth century, American skilled labor increasingly outcompeted their Canadian counterparts for skilled positions. Canadians found opportunities for advancement by working with Americans both in Canada and the US and some went to US mining schools. Still, progress in skills and education proved slow. In 1890, the Royal Commission on the Mineral Resources of Ontario and Measures for their Development noted that over half the capital invested in Ontario's mines came from America, most of which were managed by skilled people from the US. The report suggested the establishment of mining schools in Canada, a strategy that the government adopted. From that time, Canadian engineers quickly rose to high

346 Wilkins, The Emergence of Multinational Enterprise, 141, and Moore, E. S., American Influence in Canadian Mining (Toronto, Canada: The University of Toronto Press. 1941), 90. 
prominence in the field both in Canadian and American operations and by 1923 four Canadians had headed the American Institution of Mining Engineers. 347

Also in the late nineteenth century, Canada invested in infrastructural developments that encouraged foreign and domestic investment, helped unify disparate markets, and promote the industrial objectives of the country. In the 1870s, the Canadian government with domestic, British and American investors first began connecting the two sides of the continent by rail. The construction of the Canadian Pacific, a transcontinental line constructed in the 1880s, and the Northern Pacific Railway, an American rail network connecting with parts of Canada, had a profound influence in the development of the national economy and opened new mineral fields where joint Canadian-American operations prospered. ${ }^{448}$ The completion also freed the hands of the Canadian Government and private investors to invest in new mining ventures and studies. ${ }^{349}$

By the early twentieth century, the Canadian and US economies had substantially integrated and Canada represented an extension of the US to the north. 350 This integration is visible in Canadian mining where Canadians participated strongly in new American mining operations, with Canadian capital investment, skilled labor and Canadian made American mining equipment. These operations still followed the character of typical American domestic operations, as they had done in Canada previously, but did so using Canadian sources that had largely melded with their

347 Mouat, Metal Mining in Canada, 1840-1950, 35-7.

348 Ibid., 31.

349 Moore, American Influence in Canadian Mining, x.

350 Aitken, Hugh G. J., American Capital and Canadian Resources (Cambridge, Massachusetts: Harvard University Press, 1961), 72. 
American counterparts. Canada was the most successful of any nation in promoting its capabilities in American mining operations and did so by offering attractive American styled alternatives.

\section{American Mining in Mexico}

America's entry and rapid domination of the Mexico's mining industry from the late1870 s marked an important symbolic change in the mining world, as it was the first foreign country that American companies dominated against foreign competition. By that time, Mexico was already a famous mining country that groups from various nations had mined for centuries. Many Americans respected Mexican mining history and the skill of Mexican miners, ${ }^{351}$ yet American companies almost solely drew on American capital, equipment and skilled labor for their mining operations in Mexico. Furthermore, while Americans often smelted ores in Mexico, they invested almost nothing in secondary industries there, such as manufacturing mining equipment or fabrication plants, which could have further utilized Mexico's mineral wealth. The benefits of American mining in Mexico overwhelmingly favored the US, including American manufacturers of mining equipment and secondary industries.

Mexico remained the country with the largest direct American investment in mining and smelting throughout the study period. American prospectors had crossed the border to look for opportunities for many years but by the early-1870s, few American mining companies were working there. In 1877, Porfirio Diaz assumed the presidency of the

351 Papers coming from the annual general meeting of the American Institution of Mining engineers of 1901 contain numerous accounts to the grand history of Mexican mining and the quality of Mexican workers. Transactions of the American Institute of Mining Engineers, containing the Papers and Discussions of 1901, relating to the Mineral Resources and Industries of Mexico 32 (1902). 
country and looked to foreign investment to improve Mexico's economic situation. He formed a strong police force to bring order to the country and offered subsidies and opportunities to foreign railroad builders. From 1879, foreign capital flowed into the country. Some of the earliest railways were extensions to American lines that simply met their American commercial goals. Soon though, foreign investors, particularly those who had built America's railways, began constructing railways to service Mexico itself. A few decades of booming investment in the railway sector extended Mexico's rail links dramatically and to the beginning of the twentieth century, was easily the largest national sector of direct US investment anywhere in the world. ${ }^{352}$

Railway lines supported investments in mining, particularly from the US, opening new mineral lands and better connecting with old ones. The Mexican mining laws of 1884 and 1892 also supported new investment by providing a clear and secure method of claiming and working mineral lands. Mining claimants surged into Mexico and by 1908, 840 US mining companies operated there, replacing the railways as the largest sector of investment. Changes in US tariffs and duties on minerals made around 1890 encouraged Americans to invest in building smelters across the border. The Guggenheims and others soon erected huge smelting works to process Mexico's mined ores, which themselves promoted more investment in mining. Mexico's mining industry emerged a world player in terms of output, particularly in silver, lead and copper. In 1902, Mexico became the largest silver producing nation in the world. In 1904, Mexico became the second largest copper producing country, after the US. 353 The ousting of President Diaz in 1911 began an unruly revolutionary period in Mexican politics that damaged Mexico's ability to

352 Wilkins, The Emergence of Multinational Enterprise, 114. 353 Ibid. 
attract new investment. The final years of the study period were one of declining US investment in all areas of the Mexican economy, except in oil extraction.

American companies of this period show an overwhelming pattern of technology importation from the US. Americans rarely joined with local capital in their business ventures, preferring full American ownership with almost no exception. American companies hired thousands of Americans to fill positions and manage their operations while drawing on local labor for lower order positions. They also drew the bulk of their technological needs from the US, thus strengthening the American manufacturing sector rather than helping develop one in Mexico. ${ }^{354}$ Americans also brought modern ore processing methods that superseded existing Mexican methods. 355 One contemporary commentator wrote that by 1885 , American manufacturing companies had sent over 1000 American stamps to Mexico. 356

The case study of the Las Esperanzas coal mines shows the pattern of American exploitation of Mexican minerals at work and brings a view of the speed of coal mine development in a difficult, isolated region that contrasts with the Arctic Coal Company. In the spring of 1899, J. L. Elliot and E. D. Peters found potentially valuable coal reserves in the northern Mexican state of Coahuila (then Coahuila de Zaragoza). ${ }^{357}$ James T. Gardiner, a mining engineer from New York, soon examined and confirmed the find and

354 Ibid.

355 Spence, Mining Engineers and the American West, 292.

356 McDowell, F. H., 1885. "American Mining Machinery in Mexico and Central America." Transactions of the American Institute of Mining Engineers, 13:408-417.

357 The details of the company provided here came from: Ludlow, Edwin, 1901. "The Coal-Fields of Las Esperanzas, Coahuila, Mexico." Transactions of the American Institute of Mining Engineers, containing the Papers and Discussions of 1901, relating to the Mineral Resources an Industries of Mexico, 32 (New York: The American Institute of Mining Engineers, 1902). 
New York investors, including the wealthy banker George Foster Peabody organized the Mexican Coal \& Coke Company in New Jersey in June, with millions of dollars capital available for development. 358

Diamond drilling revealed the presence of an estimated 50,000,000 tons of workable bituminous steam and coking coal in a seam $6-8$ feet thick covering an area of about 6000 acres. Attempting to develop operations in as little time as possible, Superintendent Edwin Ludlow planned and constructed an operation entirely using American capital and technologies. Construction began in earnest in November 1899 and by November 1,1901 the company boasted the extraction of 1,200 tons of coal per day, coking around $18 \%$ of it, which it traded with smelting companies in the United States and Mexico. The company soon dominated coal and coke production in Mexico and continued to use American engineers to lead the expansion of its operations. 359 The operation featured three American coal tipples, an American coal washing facility, a 10mile standard gauge railway with American locomotives and 224 beehive coking ovens built with American firebrick.

Like the Arctic Coal Company, the Mexican Coal \& Coke Company had difficulty securing a stable workforce and needed to train people predominantly from an agricultural background, which Ludlow blamed for a lower than expected output. The company appears to have always used American managers and engineers in the highest positions of authority, from Superintendent to foremen, although it found Americans preferred to work in the US and was challenged in filling these positions. A British visitor wrote of the

358 Saward, Frederick Edward, The Coal Trade: 1906 (The Coal Trade Journal, 1906), 9. 359 Based on references to the company in contemporary engineering and mining journals. 
company "American methods have been used throughout and the mine differs but little from an American plant except as to the labor."360

\section{American Mining in the Caribbean, Central and South America}

Prior to the Spanish-American War of 1898, American mining companies made little headway in exploiting the ores of these regions. Americans dominated a silver and gold rush in Honduras beginning at the end of the 1870 (discussed below) and some companies invested in countries such as Cuba, Bolivia and Ecuador but by 1897 American direct investment in mining and smelting in these regions remained a paltry $\$ 11$ million. After the war, American investment in mining and smelting jumped. South America easily led the group, rising with astonishing rapidity from $\$ 6$ million in 1897 to \$221 million in 1914, overtaking Canada as the second largest region for American direct investment. Caribbean and Central American mining and smelting took a much more moderate rise, offset by huge increases in other areas such as agriculture. ${ }^{361}$

After the war, investment in South American mining and smelting largely came from a handful of huge American corporations seeking to expand their resource base with the US as their primary market. ${ }^{62}$ Copper mining easily dominated this investment, discussed earlier, and brought American technology, capital and management to South America. From 1906, the American Vanadium Corporation began mining Peruvian vanadium and soon was the world's largest supplier. Oil companies, including Jersey

36o Calderón, Roberto R., Mexican Coal Mining Labor in Texas and Coahuila, 1880-1930 (College Station, Texas: Texas A\&M University Press, 2000).

361 Wilkins, The Emergence of Multinational Enterprise.

362 Wilkins, Mira, 1975. The Maturing of Multinational Enterprise: American Business Abroad from 1914 to 1970 (Cambridge, Massachusetts: Harvard University Press, 1975), 10. 
Standard, began exploration and extraction of oil in Peru and Columbia. In 1913, the Bethlehem Steel Corporation leased a large iron mining enterprise in Chile as a supply for its US steel operations. ${ }^{363}$

The reliance of these operations on American manufacturing companies to supply machinery they needed is visible in the sales figures of US mining equipment manufacturers to South America, which rose from \$38 million in 1900 to $\$ 146$ million in 1913. ${ }^{364}$ By 1914, American companies had only just begun to install branch sales offices in South America and almost no companies did any sort of manufacturing or assembly there. By World War I, America had also only begun establishing strong transportation links with South America while Britain and Europe had long had such links and local social connections. Britain in particular had significantly larger investments in South America than the US, providing American mining companies with ample opportunities to learn about and access British and European technologies and personnel for its operations. The structure of American mining investment there, however, precluded any need to consider that option.

The history of American mining companies in Honduras shows that they followed the same pattern of behavior in their technological choices as those in Mexico. Honduras is a small Central American country with gold districts to the north and south and a notably rich silver belt around fifty miles wide stretching across its center. The Spanish extensively worked many of Honduras' mineral veins, particularly silver, from the early sixteenth century, producing around four-fifths of the ore the Spanish took from Central

363 Wilkins, The Emergence of Multinational Enterprise. 364 Ibid, 191. 
America. 365 Honduras' population declared independence in 1821, forcing out many existing Spanish mining companies. While some mines ceased operating, native Honduran companies continued many of the mining areas. Local efforts generally used simple technologies and non-scientific approaches, limiting extraction to easily accessible areas. 366

The Honduran government encouraged investment in the country by foreign nations from 1876 with the inauguration of a liberal government under Marcos Aurelio Soto, followed by liberal leadership under Luis Bogràn, Honduran president from 1883-91. Both presidents saw foreign investment as an avenue to the advancement of the country. Through the provision of concessions to foreign companies, changes in the mining code, legal protection, and active government assistance to mining company interests, about 100 mining companies formed, most between 1883 and 1887.367 The initiatives attracted investors from England, France, Honduras and particularly America, who the Honduran government especially courted and who quickly dominated mining there. Many of these companies attempted to reopen historic mines or mining regions with new methods and equipment.

By 1887 , Americans were the largest investors in mining in Honduras with $\$ 9,276,000$ invested. By 1891, two of the three largest mining companies in the country were American and one of them, the New York \& Honduras Rosario Mining Company,

365 Lombard, Thomas R., The New Honduras: Its Situation, Resources, Opportunities and Prospects, Concisely Stated from Recent Personal Observations (Chicago: Brentano's, 1887).

366 W. A. Thatcher, 1891. "Mining in Honduras," Transactions of the American Institute of Mining Engineers, 20:395-6.

367 Finney, Kenneth V., 1979. "Rosario and the Election of 1887: the Political Economy of Mining in Honduras," The Hispanic American Historical Review, 59(1): 81-107. 
continued to be the largest mining company in the country well into the twentieth century. ${ }^{368}$ The American companies predominantly brought machinery from the Rocky Mountains region to work their claims. The New York \& Honduras Rosario Mining Company led the modernization by introducing scientific mining practices and all American mining, milling and transportation equipment to its historic mines at Puerto Cortes. ${ }^{369}$ This operation continued growing after the study period with American equipment including advanced California gold mills and an American made flotation plant.370 American companies working gold placer deposits used Californian hydraulic mining methods and experienced financial losses because that approach was poorly suited to the Honduran environment. ${ }^{371}$

At least two American companies opened smelting works in Honduras, both with smelting technologies from the US. The Cuasucarán and California Mining and Milling Company introduced a California gold mill style plant and a Russell Lixiviation processing plant that failed to function well. The Los Angeles Mining and Smelting Company introduced a smelter from San Francisco but it failed to function profitably. The company, then much smaller, turned to erecting native Honduran smelting technology, called chimbos, and found some success. ${ }^{372}$

American companies that found their claims promising typically invested in American stamp mills over existing cheaper alternatives. Many companies failed while upgrading

368 Lombard, The New Honduras.

369 Finney, In Quest of El Dorado, 172.

370 Weed, Mines Register, 1753-55.

371 Finney, In Quest of El Dorado, 158. 372 Ibid., 201. 
with this expensive equipment where earlier Spanish companies had succeeded with cruder methods. 373 While ore matrix is an important factor in the choice of appropriate milling technology, arrastra technology often out performed stamping in both cost and effectiveness. Arrastras grind ores by dragging a stone over them in a circular stone pit and allow mineral recovery through amalgamation. ${ }^{374}$ This study has found no evidence of American mining companies adopting or continuing existing arrastras at any of their mines, despite their existence at many mine locations and proven effectiveness.

Few examples deviate from the pattern of using American methods, equipment, capital and skilled labor in American operations, mostly matched by special circumstances. Major Edward A. Burke of New Orleans looked for funding in Britain, probably because he was a wanted man back in the US. The Cuasucarán and California Mining and Milling Company hired a British man to lead its operations, probably because he had worked that mine for many years. Already stated, the Los Angeles Mining and Smelting Company constructed native smelting technologies after is lost most its capital on American ones. 375

\section{American Mining Outside the Americas}

While contemporary European mining companies attempted mining across much of the world, American companies focused mostly on the Americas. When asked about this, Thomas H. Leggett, an American mining chemist, replied "I think, too, that this [the Siberian mineral fields] is too far afield for American capital, just as South Africa has

373 Ibid., 221.

374 Van Bueren, Thad M., 2004. "The 'Poor Man's Mill': A Rich Vernacular Legacy.” IA, The Journal of the Society for Industrial Archeology. 30(2): 5-23.

375 Finney, In Quest of El Dorado. 
always been considered to be too distant ... American capital in the mining field certainly has been largely restricted to this continent, and apparently with good reason, considering the undeveloped areas that have existed and still exist." ${ }_{376}$

Like the Arctic Coal Company, the American mining companies working outside the Americas existed further from American manufacturing centers, American markets and often American political influence. There, companies largely exploited four regions: Korea, the Philippines, Cyprus and the Congo. Case studies of the American mines in these locations highlight the impact of distance on the pattern of technology adoption when compared with mining in the Americas.

\section{Korean Gold Mining}

The Korean Royal House invited European and American investors to exploit its gold in the late-nineteenth century as a way to generate revenue, train Koreans in modern mining methods, and to counterbalance growing Japanese power in the region. 377 Political factors, particularly between Russia, Japan, Korea, America and European nations form the contextual background to these investments. ${ }^{378}$ Two large American concerns flourished there before Japanese domination forced them out before the beginning of World War II: The Oriental Consolidated Mining Company and the Seoul Mining Company. Close inspection of those companies' choices for ore reduction technologies is revealing of people in those decisions.

376 Interview with Thomas H. Leggett in Rickard, Thomas Arthur, Interviews with Mining Engineers (San Francisco: The Mining and Scientific Press, 1922), 269.

377 Palmer, Spencer J., 1962. "American Gold Mining in Korea's Unsan District." The Pacific Historical Review, 31(4): 379-391. At least one Japanese firm received a concession in Korea.

378 For an extensive treatment of the political forces at work, and a wider view of foreign investment in Korea, see: Arnold, American Economic Enterprises in Korea. 


\section{The Oriental Consolidated Mining Company}

The Korean Peninsula remained closed to foreigners until 1876 and to foreign mining until 1883, when a short-lived British firm began gold mining there. In 1895 the Royal House of Korea granted a 25 year mining concession in the Unsan district of northern Korea to Mr. James R. Morse, an American. They later granted concessions to other interests from Britain, France, Germany, America. The Royal House set conditions on the concession with a $25 \%$ royalty on net profits and no importation tax on mining supplies. Prospecting mining engineers under Morse found large veins of low-grade quartz but provided an unfavorable report on its economic viability and Morse sold the concession to a group of American investors in 1897.379

The investment group opened the Chittabalbie Mine in 1897 and erected a stamp mill using a light 10-stamp borrowed from the Royal House that had been brought to Korea from California for an earlier failed British mining operation. Later that year, the company added ten heavier stamps. The group amalgamated the ore at the mill and then shipped the remaining concentrate to the Tacoma, Washington, for further processing. By good fortune, this mine produced a high-grade gold ore that allowed simple extraction procedures to be used. By the time of its closing in 1905, this mine had produced about $\$ 1,500,000$ worth of ore, which the company used to fund further expansion of operations into lower grade gold ore areas with little new investment. In 1899, the company opened the Tabowie mine with a 20-stamp mill with the intention of also sending its concentrates to the US.

379 Palmer, "American Gold Mining in Korea's Unsan District." 379-383. 
In 1900, the group hired prominent American mining engineer Henry C. Perkins to examine the property. He gave a favorable report and reorganized a new company to take over the existing concessions and operations. He formed the Oriental Consolidated Mining Company under the laws of West Virginia with $\$ 5,000,000$ capital by bringing in new American investors to join the existing group. ${ }^{380}$ Perkins took the position of president and led the company for many years. From that time, the company continued to expand and open new mines, all of similar design and following the California stamp mill form, and upgraded the milling processes to include cyanide processing and thereby extract a greater percentage of ore.

Once established, the new company pushed extensive prospecting efforts across its concession. This work was aided by the fact that Korean groups had already mined all of the areas the company chose to open up. The Oriental Consolidated mining Company opened mines in four new areas in rapid succession. It opened the Kuk San Dong with a 20 stamp mill in 1900, later expanded to 40, the Maibong with a 40 stamp mill in 1902 and the Taracol mine in 1903 with an 80 stamp mill. In 1908, mines were opened at East Candlestick and West Candlestick, each equipped with a small mill.

While the gold ores of the Chittabalbie were rich enough to support transportation to America for secondary treating, the ores found at Tabowie, and at all of the company's subsequent mines, were not. As the California gold mills there recovered less than $50 \%$ of the gold ores through standard mercury amalgamation practice, the company turned to on site cyanidation to improve yields and it hired a British metallurgist and chemist, S. J. Speak, to analyze its ores and find economic processing solutions. ${ }^{381}$ Before arriving

380 British and French investors later became shareholders. 381 Arnold, American Economic Enterprises in Korea, 221. 
in Korea, Speak had gained foreign experience in mining metallurgy in Australia, South Africa, and West Africa and was able to provide thoughtful advice on contemporary approaches.

In 1901, Speak installed a small cyanide percolation plant at the Tabowie mine. The technology was outdated and generic but it allowed him to test the company's ores. Later that year, he suggested that the cyanidation approach adopted in Southern Africa's Witwatersrand gold region would best suit the company's ores best. Mining companies of the Witwatersrand region had largely adopted the German developed Siemens-Halske approach, an adaptation of the MacArthur-Forrest approach of Scottish origin that used electrical deposition to remove gold from cyanide solution rather than using zinc shavings. ${ }^{382}$ The company considered Speak's recommendation uneconomical and Speak simply adjusted the existing percolation plant to work as best as possible. He installed a simple cyanide agitation plant at the Maibong mine the same year, but found it less efficient than the plant at Tabowie. In 1903, the company finished construction of a large, low-cost cyanide percolation plant at the Taracol mine with around a 20-day cyanidation cycle. ${ }^{83}$ As with the other plants, the equipment was generic, and did not represent any particular national approach. The facility recovered an average of $84 \%$ of gold in the ore and continued as the company's central cyanide plant for many years.

Seeking to improve gold recovery rates, the Oriental Consolidated Company hired American metallurgist A. E. Drucker to lead the management and installation of its milling and cyanidation operations. Drucker ignored Speak's suggestion and developed

382 Burt, "Innovation or Imitation?" 321-347.

383 S. J. Speak, "Milling in Korea," Transactions of the Institution of Mining and Metallurgy, 12:427-441. 
his own innovative designs for new plants. He started by building a small experimental plant adjacent the Taracol cyanide percolation plant in 1906, and a full scale facility by the East Candlestick plant in 1908, based around tube milling and zinc precipitation. ${ }^{384}$ Claiming his innovation would process ores in around 48 hours and allow total extraction rates of 92\%, he dubbed the approach the 'Drucker Process.' ${ }^{385}$ While gaining good extraction rates, the full-scale plant had smaller than expected processing abilities, mechanical issues and high costs. Drucker traveled the mining regions of the United States, India, South Africa, Australia and New Zealand for 18 months to learn from modern plants there and upgrade his approach. He made drastic adjustments to the East Candlestick plant in 1909 but the designs failed to prosper. The company dropped his designs and returned to their old plant. ${ }^{386}$ Still dissatisfied with ore recovery rates, the company charged Drucker with designing and installing new cyanidation plants, for newly mined ores, and re-cyanidation plants to re-process the tailings of the company's three simple percolation plants. Having failed with his own designs, Drucker turned to American methods and equipment.

Retreating cyanide tailings was difficult as old oxidized cyanide tailings concentrate posed difficult metallurgical problems. In 1911, he built a pilot plant at the Kuk San Dong mine, a mine that was almost exhausted of ore. ${ }^{387}$ Abandoning much of his earlier work,

384 Druker, A. E., September 22, 1906. "Tube Milling in Korea," Mining and Scientific Press, 93(12): 346-348, and A. E. "Tube Mill Lining, November 17, 1906. "Mining and Scientific Press, 93(20): 594-5.

385 A. E. Drucker, April 4, 1908. "Treatment of a Concentrate-Slime," Mining and Scientific Press, 96(14):458-460.

386 J. D. Hubbard, October 2, 1909. "Cyaniding Concentrate at Taracol, Korea," Mining and Scientific Press, 99(14):471-3.

387 A. E. Drucker, January 13, 1912. "Kuk San Dong Cyanide Plant," Mining and Scientific Press, 104(2):103. 
the plant, he said, resembled a plant at the Alaska Treadwell mine, Alaska. ${ }^{88}$ He ordered the equipment for this mill from US manufacturing companies and the results were reasonably successful. Drucker began constructing a larger retreating plant at the Taracol mine in 1912, which appears to have remained incomplete.

In 1912, Drucker completed a regrinding and cyanidation plant at Taracol to supersede the simple 1903 percolation plant. The new plant would treat the amalgamated concentrates coming from the Taracol and Tabowie mines, as well as the ores coming from Korean mining leases of the company's lands. Drucker again used an assortment of American manufactured equipment for the cyanidation process, resembling those used at the new re-processing plant at Kuk San Dong. He projected that the new mill would be able to recover $91 \%$ of the gold mined, an improvement on the percolation works but still unimpressive by contemporary standards. Mechanical problems plagued the facility and the company quickly adjusted its classification and grinding facilities in an attempt to improve its operations. Ultimately, the new plant got only a slightly better extraction rate than the percolation works but was much more expensive to operate. The company abandoned the new plant in late 1913 and again returned to its old facility, continuing with it for many years. Despite low recovery rates and continual failure with American processing technologies, the Oriental Consolidated Mining Company never tested foreign alternatives which the Seoul Mining Company found great success with, as discussed below.

Americans always dominated the ownership and management of the Oriental Consolidated Mining Company, who sought out American foremen, particularly from the

388 Ibid, 103. 
western states, to supervise the operations. ${ }^{389}$ In 1919, the company had 45 foreigners working on its concession. The British metallurgist, S. J. Speak, is the sole known example of a non-American working for the company.

The associated Chosen Mining Company is another example of an American mining company overseas utilizing an all American management force and American machinery. Two American men formed the company in 1911 under the laws of Arizona with $\$ 50,000$ capital and hired Perkins of the Oriental Consolidated Mining Company as President. 390 The company opened the Kosung mine and hired the Oriental Consolidated Company's American metallurgist J. D. Hubbard to test the local ores and design a reduction plant. Hubbard recommended a direct reduction plant and the company ordered the plant through Allis-Chalmers Co., an American ore dressing equipment manufacturing company with a branch office in Japan. ${ }^{391}$ The mine gave disappointing results and the company sold out in 1919 .

\section{The Seoul Mining Company}

In 1905, the Korean Royal House granted a British mining engineer, Arthur L. Pearse, a 35 year concession of 160 square miles of land in central Korea, containing gold and copper, as well as bismuth and tungsten ores, carrying an annual tax and $1 \%$ royalty on annual output. For the next three years, the Korean Syndicate (British), the Mitsui and Company (Japanese), and Collbran and Bostwick, an American firm financed through

389 S. J. Speak, "Milling in Korea," 427-441.

390 Arnold, American Economic Enterprises in Korea, 366-7.

391 Hubbard, H. D., "Gold Mining in Korea," Mining \& Scientific Press 105(3): 83-5 and Hubbard, H. D., "Chosen Mining Company's reduction Plant," Mining \& Scientific Press 106(14): 510-13. 
London houses, collaborated on the property, prospecting and examining options for exploitation. In 1908, after its partners had effectively pulled out of the property, the American concern, Collbran and Bostwick, proved profitable gold ore bodies. It purchased the rights, titles and interests of the property from the Korean Syndicate giving it an $8 \%$ royalty and a one-fifth interest in a new company, and incorporated the Seoul Mining Company in Connecticut with a head office in Denver, Colorado, with $\$ 500,000$ capitalization. 392

While an American company under an American General Manager, the Seoul Mining Company always retained an international outlook, likely due to the multi-national character of its beginnings. The president of the company, Harry Collbran, grew up in Britain but became wealthy in Midwestern and Colorado railways and became a naturalized American in 1881. Collbran collaborated closely with the American government in his interests in Korea but the company's top-ranking workforce consisted of Americans and Britons. One Australian, A. R. Weigall, participated in the early formation of the company and later returned to be its General Manager. The company drew on scientists from Britain, America and Australia to analyze the concession's geology and ores and sent its ores to both Britain and America for processing. It looked to British, Australian, and American expertise to introduce the new flotation technology to process its complex ores. 393 While much of the mill machinery came from America and represented the California gold mill or post-California gold mill style technologies, it had greater access to world skills and technologies than most American companies because of the international character of its management.

392 Weigall, A. R. and J. F. Mitchell-Roberts, 1919. "Technical Operations on the Suan Concession - 1," Mining and Scientific Press, 119(1919), 509-519.

393 Arnold, American Economic Enterprises in Korea, 369. 
The Seoul Mining Company took a highly scientific approach to developing the mine. It made extensive and detailed geological investigations of the property and designed mills and workings suited to the nature of the ore and geological conditions. 394 Based on ore analysis done in San Francisco, the company built a 20-stamp California gold mill style milling operation, the 'Suan Mill,' in 1909, and expanded it to a 40-stamp operation in 1910. At its Tul Mi Chung mine, the company sought to work difficult gold, silver and copper deposits and turned to flotation technologies. While mineralogists, scientists, and mining people from around the western world made advancements to flotation technology, Australian and British companies contributed the most crucial developments in Broken Hill, Australia, from 1900 to around 1910.395 The Seoul Mining Company tapped into this expertise by sending ore samples to both Britain and Australia for examination. The company may have benefitted from having on staff an American geologist who had previously worked for Mineral Separation Limited, a British firm that had contributed to recent advancements in flotation technology. Satisfied with the Australian analysis, the company added a test flotation plant, based on a British design, to its existing milling plant in 1913. After experimenting with that plant, the company built a new, full-scale milling plant with flotation technology. 396

Engineers designed the technologically complex Tul Mi Chung mill to specifically match the ore matrix of this area, with ball mills and pebble mills replacing the stamps. All the equipment for this mill came from American manufacturers save the flotation mill, which was of a British design, and the Danish Pebbles used in the pebble mill coming

394 Weigall et al.,"Technical Operations on the Suan Concession - I," 509-519.

395 Blainey, Geoffrey, The Rush that Never Ended: A History of Australian Mining, 4th ed. (Carlton, Victoria: Melbourne University Press, 1993), chapter 22.

396 Weigall et al.,"Technical Operations on the Suan Concession - III," 805. 
from Greenland. Ancillary equipment introduced around this time, such as the powerhouses, appears to have come from the US. 397

\section{The Philippines}

After the US occupied the Philippine Islands in 1898, teams from the Bureau of Science investigated and promoted industrial and agricultural possibilities there. The government placed particular emphasis on mineral resources to improve the local economy and to provide military installations with coal. Investigations revealed that the Philippine archipelago had significant quantities of coal and gold as well as some copper and iron. 398 Prospectors and companies, particularly from the US but also from Australia and New Zealand, responded and a modern mining industry slowly emerged in the country. Bureau reports show that while the Australasian groups looked to several manufacturing centers around the world for their equipment needs, American companies almost exclusively used US suppliers. This pattern is visible in the coal, hard rock and placer gold mining performed on the archipelago.

The US government was particularly interested in establishing a local coal supply to supports its naval base there, eliminating the need to bring coal from Australia or Japan. While the Philippines used little coal, the US Navy base required considerable amounts. Coal had first been discovered in the Philippine Islands in 1827 and attempts at mining

397 Ibid., 805-815.

398 The government published findings in detailed annual reports: The Philippines Division of Mines, The Mineral Resources of the Philippine Islands (Manila: Bureau of Printing, and United States Philippine Commission, 1908 - 1912) and Report of the Philippine Commission to the Secretary of War (Washington D.C.: Government Printing Office, 1900-1916). 
started in the 1840s. ${ }^{399}$ Bureau investigations found coal deposits throughout the archipelago, with the island of Batan showing particular promise. From 1901, the US Army sporadically funded geological exploration in that area and operated a mine there from around 1904 to 1907, when it closed for lack of funds. Around 1910, the government reopened the mine and the army updated the operation with modern equipment, entirely of US origin, and a skilled American workforce. With American equipment and American skilled workers, the mine most likely featured the American preferred room-and-pillar mining method. The government also promoted various local coal mining companies. It worked with the East Batan Coal Company, a Philippine company, possibly funded by Americans living in the country, by giving it contracts for coal and by building infrastructure. This company used American equipment and expertise and adopted the room-and-pillar mining approach.

Gold dredging efforts best reveal the strong American preference for American people and technologies in the Philippines. American companies consistently chose American dredging technology despite viable alternatives available from New Zealand, which was also located closer than American suppliers. New Zealand engineers took the lead in developing dredging technology from the 1860s. By 1881, the first commercially successful gold dredge worked the soils of the Clutha River, New Zealand, and by 1902 New Zealand boasted 292 dredges. While the United States had made considerable advances in general dredging technology, it lagged in dredging for minerals. The first commercially successful gold dredge operated in Montana from 1895. Later that decade, the Risdon Company began manufacturing dredges, initially based on designs from a New Zealand engineer, and soon drawing on aspects of dredging in Chicago and 399 US War Department, Report of the Philippine Commission to the Secretary of War, 1908 (Washington D.C.: Government Printing Office, 1909), 369 
Montana. Californian dredges came to dominate the industry with a superior design, whose heyday extended from 1905 to 1920 as engineers continually improved the design for lower grade placer deposits. 400

With the exception of one very small dredge built in the Philippines in 1896, gold dredging commenced in the Philippines from 1903 when an American firm, the Philippine Mining Company, brought a Risdon dredge from San Francisco. The dredge failed and the company appears to have abandoned it. In 1905, The Oriental and Masbate Dredging Company, an American company, also brought a Risdon dredge to the Islands but this dredge also failed to function properly. The dredge was tried in two other locations before working properly. Two New Zealand companies worked the area in 1907 and 1908, bringing New Zealand dredging technology with them. For several years, their dredges were the most productive in the country and one company, the Paracale Gold Dredging Company, dominated the country's gold mining and continued to grow and expand. An Australian group eventually bought it out and built at least three more dredges, combining New Zealand and Australian design features. These Australasian companies used other mining equipment from New Zealand, the US and England while American companies never swayed from American equipment. In 1912, the Gumaus Placer Company constructed a very large dredge designed by the New York Engineering Company. This time, the American dredge proved successful and was the largest extractor gold in the remainder of the study period. Other minor dredging companies

400 Spence, Clark C., "The Golden Age of Dredging: The Development of an Industry and Its Environmental Impact.” The Western Historical Quarterly, 11(4, Oct., 1980): 401-414. 
worked in the Philippines at this time but the national origin of either the company or their equipment is not known. 401

Hard rock mining efforts in the Philippines focused mostly on gold extraction, where again American companies also preferred American equipment. At least eighteen companies advanced to the stage of installing milling machinery on their properties in the study period, the great majority likely coming from the US. Of these, fourteen companies used American milling technology, probably of the California gold mill form. The other four companies were very small and used milling machinery fabricated in Manila, the Philippines. The US Government studies records no machinery from any other nation being used on the Philippines at the time.

\section{The Cyprus Mines Corporation}

The bulk of development of the copper regions of Cyprus by the Cyprus Mines Corporation occurred after the close of the study period and, as such, this section offers only an overview summary of its activities. After successfully developing the Ray Mine, a pyritic copper mine in Arizona, from the late-nineteenth century, Seeley Mudd and Philip Wiseman funded Charles Gunther to prospect the historic copper regions of Mexico, Egypt, Spain and Cyprus. Satisfied with his finds in Cyprus, Gunther secured two prospecting permits at Skouriotissa and convinced Mudd and Wiseman to fund a pilot operation. The men organized the Cyprus Mines Corporation in 1916 under the laws of NY and based their American offices in Los Angeles. ${ }^{402}$

401 The Mineral Resources of the Philippine Islands, 1908- 1912 and Report of the Philippine Commission to the Secretary of War, 1900-1916.

402 This case study is based on Lavender, David, The Story of Cyprus Mines Corporation (San Marino, California: The Huntington Library, 1962). 
Drawing on the advanced knowledge and technologies of the American pyritic copper mining sector from 1914, the group prospected the landscape and constructed a simple, small and somewhat improvised operation under American management using local, European and British labor and foremen. From 1918, the company attempted to raise further capital for the development of a full-scale operation but found meager interest in the US and Europe. By 1922, the company funded the upgrade through selling a $25-45 \%$ interest to a European conglomerate, increased investment by primary shareholders and by taking out loans. The operations began financial success around 1924 with annual sales of over 100,000 tons to European markets and continued to operate into the latetwentieth century.

The company upgraded the works in the 1920 s using American equipment for the most technologically complex elements, such as power houses and milling equipment, British sources for some more basic equipment and materials, and local sources for simple materials such as timber. Until at least the 1930s, it always hired Americans for the highest positions, predominantly American and British foremen, and a majority of local peoples for mining and unskilled labor. The Cyprus Mines Corporation largely fits the typical pattern of technology choices by American mining companies overseas, particularly in terms of the labor policy and technologies purchased. The company partially deviated from the pattern when it sought European investment capital and by marketing to European copper markets.

\section{Forminière / The American Congo Company}

The American Congo Company and its parent Forminière represented the sole American mining investment in Africa known by the author in this period. While secondary sources disagree on the nature of these related companies, it is clear that Americans 
owned up to half of the diamond operations of the Belgian Congo and that they collaborated with the Belgian colonial government to develop and operate the mines. In this way, the operation represents a mix of American and European approaches, and of capitalism and colonialism.

In an effort to counter a strong reform movement and the threat of annexation of Congo by Belgium, King Leopold II courted British, American and European political and commercial groups on his interests in the Congo. American investors including Senator Nelson W. Aldrich, Thomas Fortune Ryan, Bernard Baruch and Daniel Guggenheim, partnered with Belgian investors and himself to develop the mineral and agricultural resources of the region. The American investors, all major investors in the Continental Rubber Company, saw potential in the development of rubber plantations there. Some, especially Thomas Ryan and Daniel Guggenheim, were also interested in the potential of finding lucrative mineral deposits, then little explored. ${ }^{403}$

In 1906, King Leopold II negotiated the creation of the Sociètè Internationale Forestière et Minière du Congo, also known as Forminière. Daniel Guggenheim and Thomas Fortune Ryan registered the American Congo Company in NY with a capitalization of $\$ 510,000$ to explore and exploit the mineral resources of Forminière. ${ }^{404}$ American interests took between $25 \%$ and 50\% interest in Forminière, the rest retained by Leopold, Belgian investors, and the Congo Free-State. The organizations established head offices in both New York and Belgium, cementing a close co-operative,

403 Sternstein, Jerome L. 1969. "King Leopold II, Senator Nelson W. Aldrich, and the Strange Beginnings of American Economic Penetration of the Congo." African Historical Studies, 2(2):189-196.

404 O'Connor, Harvey, The Guggenheims: The Making of an American Dynasty (New York: Covici Friede, 1937), 97. 
government/private, approach to the exploitation of Congo's natural resources. In 1908, the Belgian government annexed the state, and re-arranged the grants and obligations of the company. The co-operative arrangement and goals of the company remained largely in place and dual-national management structure of the operation continued well into the future. 405

Investor interest in rubber opportunities quickly dropped as they realized the scale of capital and time required. Mining, on the other hand, prospered when a team working in Belgium found a diamond sample in 1909. A Guggenex ${ }^{406}$ prospecting team then went to the area and found a significant quantity of diamonds near the Kasai River in 1911.407 The operation grew rapidly from about 100,000 carats in 1913 to 200,000 in 1918 ; it was the largest diamond exporter in the world after the inter-war period. Correspondingly, the workforce grew from several hundred in 1913 to about 7000 in 1919. These fields were shallow and for several decades the mining operations were largely non-mechanized, relying instead on local labor based in temporary work camps. 408

The Forminière / American Congo Company operations represent the blurred coordination of American and European capitalism and Belgian colonial policy in a way that makes it impossible to delineate the specific influence of American mining practice.

405 Derksen, Richard, 1983. "Forminière in the Kasai, 1906 - 1939." African Economic History, 12: 50 .

406 Guggenex, or Guggenheim Exploration Company, was a prospecting company created by the Guggenheims in 1899. Unger, Irwin and Debi Unger, The Guggenheims: A Family History (HarperCollins, 2005), 74.

407 Unger and Unger, The Guggenheims, 97.

408 Derksen, "Forminière in the Kasai, 1906 - 1939," 54-55. 
Technologically, the operation always remained relatively simple and Belgian colonialism led the policy towards labor and settlement. The Americans were a fairly passive force within colonial goals, what Stenstein calls the American investors' “imperialism without effort.” ${ }^{409}$

\section{American Mining Engineers Overseas}

American mining engineers followed a somewhat different pattern of behavior to the conservative companies of the US. Desired by mining districts around the world and profoundly influencing the direction of mining through their work, Herbert Hoover described the quarter century leading up to World War I as the golden age of American mine engineers. ${ }^{410}$ From Australia to Japan, Siberia, South Africa and elsewhere, American mining engineers brought their skills to bear on the major ore bodies of many foreign countries. While these men usually had a general preference for American methods and technologies, they were adaptable in their approaches through working with engineers of other nationalities.

Perhaps the most famous foreign mineral region influenced by American engineers at that time is the Witwatersrand in the Transvaal of Southern Africa, one of the most productive gold regions in world history. Otherwise known as the Rand, the area stood inside the Boer Republic during the early mining phase until 1902 when the British government took control. Major exploitation started in a rush in the mid-1880s and European and British companies quickly established themselves on the 'main reef.'

409 Sternstein, "King Leopold II, Senator Nelson W. Aldrich, and the Strange Beginnings of American Economic Penetration of the Congo." 204.

410 Hoover, Herbert, The Memoirs of Herbert Hoover: The Years of Adventure, 1874-1920 (New York: The Macmillan Company, 1951), 161. 
Immediately, American mining engineers found themselves in demand with support of H. C. Perkins and Hamilton Smith, two mining leaders that had influence with the major figures working the Rand. ${ }^{411}$ Perkins and Smith had worked in the hugely profitable El Callao gold mine in Venezuela in the 1870 s with several American mining engineers who they then invited to work on the Rand. ${ }^{412}$

Working with mining engineers from around the world, the Americans dominated efforts to open this region until 1910, when mining companies began seeking more British and local engineers. From 1893-99, well over 60 American mining engineers worked on the Rand at any time. In 1903, ten of the fifteen members of the influential Transvaal Chamber of Mines, representing the major mining houses of the region, were American. ${ }^{413}$

The American mining engineers' tendency towards bold and adaptable decisions suited the difficult mineral environment they faced and they led development that lent on both American and European technologies. Rand mines adopted American sorting practices and relied on the American speed of shaft sinking and adopted European blasting gelatin, steel and electrical equipment. Americans focused on preparing the mines for economies of scale through mass mining and processing techniques but did so with equipment from both British and American sources. ${ }^{414}$

\footnotetext{
411 Interview of Hennin Jennings in Rickard, Interviews with Mining Engineers, 244. 412 Katz, Elaine, 2005. "The Role of American Mining Technology and American Mining Engineers in the Witwatersrand Gold Mining Industry 1890 - 1910." The South African Journal of Economic History, 20(2):66.

413 Ibid., 48-50.

414 Ibid., 48-82.
} 
Some countries invited American mining engineers to bring American advanced methods of mining and metallurgy to their mining regions. Americans had worked with Australian minerals since the gold rushes of Victoria and New South Wales in the 1850s but stronger collaboration waited until the 1880s. The Broken Hill Proprietary (BHP), of New South Wales, made a great break with typical Australian practice by hiring Americans to be General Manager and head metallurgist in 1886.415 From that time, a stream of mining engineers from the American West joined Australian operations and several mining equipment manufacturers established branch offices there. ${ }^{416}$

Other American mining engineers joined European mining houses to represent their interests around the world. In 1897, Herbert Hoover joined the large British mining house, Bewick, Moreing and Co. and worked for them in Australia, China, South Africa, Burma and Russia. 417 John Hays Hammond worked for British and European companies that took him to Zimbabwe, South Africa and Russia. ${ }^{418}$ While both men displayed a general preference for American practice and equipment, they also drew from other sources in their operations. Hoover, for instance, adopted Australian advancements on flotation concentration technologies for different operations under his control.

Scott Turner had similar attitudes for operating mines to Hoover, which was fairly typical for Americans in the industry. Both men believed in strong management controlling and coordinating the labor force and both explicitly preferred 'white' labor at

415 Blainey, The Rush that Never Ended: A History of Australian Mining, 150.

416 Spence, Mining Engineers and the American West, 296-299.

417 Hoover, The Memoirs of Herbert Hoover.

418 Hammond, John Hays, The Autobiography of John Hays Hammond (Murray Hill, New York: Farrar \& Rinehart Incorporated, 1935). 
their operations. ${ }^{419}$ Hoover focused heavily on the efficiency of mining operations and saw quality labor as key to achieving that, since one worker could slow a group and reduce the productivity of expensive equipment. Hoover had an overt preference for American or Australian labor, who he felt could more than compensate for their high employment cost, over alternatives such as South African Kaffirs who he described as being "savages of low average mentality." 420 Similarly, Turner always viewed his Scandinavian labor negatively, once writing "this labor is inefficient when measured by American mining standards, still these workmen ... are peaceable, slow to act, and not clever enough to be efficiently treacherous." ${ }^{221}$

\section{Analysis of American Companies Overseas}

With few exceptions, American mining companies working overseas chose American capital, methods, technologies and management for their operations. In only one case other than the Arctic Coal Company did an American company chose significant alternatives. Why is this pattern so prevalent and why did the Arctic Coal Company break away from it? The most important factor behind this question was the managers and engineers that developed the operations. An all-American management and mining engineering team was likely to look to American sources while a multi-national team was much more likely and able to consider alternatives.

419 Hoover, Herbert, Principles of Mining: Valuation, Organization and Administration; Copper, Gold, Lead, Silver, tin and Zinc (New York: McGraw-Hill Book Company, 1909), 161-168. Scott Turner only saw American labor as 'white,' Dole, America in Spitsbergen.

420 Ibid., 162.

421 Arctic Coal Company Annual Report for the year from September 1, 1913 to May 31, 1914, Michigan Technological University Archives and Copper Country Historical Collections, Longyear Spitsbergen Collection (MS-031), box 4, folder 15. 
The two American companies that used diverse sources of technology, the Arctic Coal Company and the Seoul Mining Company, could do so because they employed multinational teams. In both cases, the companies faced significant challenges to successfully developing their operations that provided incentives to consider alternatives. William Munroe lacked specific skills in coal mining and thus welcomed the leadership of and assistance of British engineers. The company also welcomed the local Norwegian knowledge provided by some of its shareholders to access goods and services available there. The Seoul Mining Company faced a difficult copper ore matrix and required advanced scientific techniques and technologies to reach economically feasible recovery levels. The diverse staff of both companies provided ready access to the technologies, approaches and skilled workers from elsewhere in the world.

Several historic studies of the technology transfer framework also point to the critical role individuals play in choosing, using and adapting technology. In its simplest form, the technology transfer framework focuses on the mechanisms that bring technology from one location to another and how that technology works in the new setting. In this way, the framework goes beyond the focus of this study because it looks at the results of transfer while this work does not. The term 'technology' here refers to specialized knowledge, technically skilled people, documentation of technology such as blueprints and technical guides, and technologies themselves. ${ }^{422}$

John Harris argues that eighteenth century France struggled to adopt advanced British industrial methods in large part because they paid insufficient attention to acquiring, retaining and effectively utilizing the skilled artisans that understood the technologies at

422 Bruland, Kristine, ed., Technology Transfer and Scandinavian Industrialisation (NY: Berg, 1991), introduction, and Lindqvist, Svante, Technology on Trial: The Introduction of Steam Power Technology into Sweden, 1715 - 1736 (Uppsala: Almqvist and Wiksell International, 1984). 
use. ${ }^{423}$ David Jeremy argues that skilled artisans were the preeminent factors in successfully transferring British textile technologies to a young American republic. ${ }^{424}$ Studies on the transfer of mining technologies outline a pattern of skilled miners and mining engineers bringing their native technologies to new areas they wish to exploit.

Alfred Rowse details how Cornish miners, throughout the nineteenth century and particularly with the collapse of Cornwall's copper mining sector in the 1860s, migrated in large numbers to the United States, bringing their mining skills and preferences with them. ${ }^{425}$ They worked in all hard rock mining forms in America, from quarrying, to tunneling, iron, nickel and copper mining but had little involvement in the coal mines, which required a different skill set than hard rock mining. The abilities and culture of these people had a profound influence on the development of mining in the US, where their skills spread, their terminology prevailed and the labor movement referenced contemporary Cornish policy. For example, Michigan's Copper Country attracted many Cornish miners in the mid-nineteenth century who helped develop the area into an economically successful and industrialized mining region. Mines there commonly employed these people as mine captains and foremen, who provided links to the Cornish copper mining and processing practice that prevailed in the region. This pattern is clearly visible at the Ohio Trap Rock Mine of the Copper Country, operational from 1848-58, where Cornish mine leadership and a predominantly Cornish workforce

423 Harris, John R. "Law, Espionage and the Transfer of Technology from Eighteenth-Century Britain." In Technological Changes: Methods and Themes in the History of Technology. Ed. Robert Fox. (London: Harwood Academic Publishers, 1996).

424 Jeremy, David. Transatlantic industrial Revolution: The Diffusion of Textile Technologies Between Britain and America, 1790-1830s (Cambridge, Massachusetts: The MIT Press, 1981).

425 Rowse, A. L., The Cousin Jacks: The Cornish in America (New York: Charles Scribner's Sons, 1969), 96. 
matched the Cornish styled technologies the company adopted. ${ }^{426}$ Beyond mining, Americans drew on European technologies across the spectrum of engineering projects in the nineteenth century, often adapting them to local conditions. 427

For most American companies, many reasons worked against breaking from their national model. By far the greatest number of American operations located themselves in Canada and Mexico, near American capital, manufacturing centers, labor and markets where it made little sense to look to more distant European or other alternatives unless for specialized needs. The majority of the remaining companies worked in the rest of the Americas where European trade links offered opportunities for using alternative technologies and people. Yet, this study has found no account of any American operation using either local or alternative options on any significant scale. The primary reason is that the American companies developed under American management and sold to US markets, which limited opportunities for outside interaction. Beyond that, many operations, particularly those in South America, existed within the framework of much larger American corporations which extended existing techniques, management strategies and supply lines. At no time during the formation or operation of these mines did the companies feel any particular need to look to outside expertise or technical sources. As the US mining sector boasted enormous strength in gold, silver and copper mining, the three minerals most commonly mined by Americans overseas, and also in iron mining and oil extraction, which Americans worked across different parts of the Caribbean, Central and South America, the companies found it easy to adopt the proven

426 Landon, David and Tumberg, Timothy, 1996: 'Archeological Perspectives on the Diffusion of Technology: An Example from the Ohio Trap Rock Mine Site', IA: Journal for the Society of Industrial Archaeology, 22 (2): 41-57.

427 Kemp, Emory L., 1993, "National Styles in Engineering: the Case of the 19th-Century Suspension Bridge," IA, The Journal of the Society for Industrial Archaeology 19(1):21-36. 
approaches of their homeland. A partial exception is Canada where a combined US/Canadian mining sector emerged.

The American mining education system may have helped support the pattern as schools shifted to an American focus in the late-nineteenth century. Most educated American mining engineers received schooling from European mining schools up to the 1870 , before American schools started to dominate. Even then, European mining texts remained core readings in American schools into the 1880 os. ${ }^{428}$ Gradually, the schools developed a stronger US focus, as shown by the curriculum of the Michigan Mining School, opened in 1886 . The school has particular relevance to this study since J. M. Longyear both supported and served in it, and three Arctic Coal Company General Managers attended as well. In the late-nineteenth century, the school provided very practical courses with no particular reference to mining practice overseas. 429 The photographic slide collection used in classes suggests that classes only referenced mines in the US and a few of Mexico. ${ }^{430}$ Just like the broader American mining engineer community, this education did not prevent Michigan Mining School graduates from working across the world. Graduates of the period worked across the Americas and as far as England, South Africa/the Transvaal and Australia.431

428 Spence, Mining Engineers and the American West, 24-39. 429 Michigan Mining School: Catalogue and Prospectus, 1894-1896, (Houghton, MI: The Michigan Mining School, 1896).

430 Photo Index Descriptions in Michigan Technological University Archives and Copper Country Historical Collections, Michigan Technological University Mining Engineering Photo Collection, box 21.

431 Michigan College of Mines, Graduates of the Michigan College of Mines (Houghton, MI: June 1910). 
The behavior of American companies outside the Americas shows that distance from the US brought additional incentive to adopt foreign alternatives but not enough to force substantial change. The Forminière / American Congo Company adopted both American and Belgian approaches to development, although the Americans in this case had little choice. The Cyprus Mines Corporation, while using predominantly American technology, methods and management, drew on European investment capital and worked within European copper markets. In the Philippines, a few American operations purchased stamp mills manufactured locally, perhaps based on American models. In Korea, the Oriental Consolidated Mining Company considered British investment capital, German concentration technologies and investigated processes around the world to improve its own concentration innovation but never succeeded in breaking from American approaches. Also in Korea, the Chosen Mining Company courted Korean and Japanese investment capital but never strayed from using all American management and technologies.

While the early management of the Arctic Coal Company exhibited an unusual approach to technology adoption compared to their American contemporaries, Scott Turner brought the company back towards more typical pattern. In this case, Turner's strong personal belief in the superiority of American men, equipment and methods drove the change, which is indicative of wider American sentiment towards America's mining abilities.

Spitsbergen's Arctic conditions had no impact on the Arctic Coal Company's decision to pursue non-American mining methods and technologies. The nature of the climate and sea conditions never entered into discussions over technology and other American mines overseas, such as the Mexican Coal \& Coke Co. and Cerro de Pasco Copper Company, 
worked in extremely difficult conditions while still using typical American approaches. The geological environment did play into the discussion as the English miners and mining engineers that examined the property testified that the geological conditions matched the longwall mining, although Turner later argued the room-and-pillar approach worked better in this respect. Spitsbergen's geographic location had some impact on the decision because its closer proximity to England supported Mangham's suggestion to pursue English mining methods. Above all, it was the Arctic Coal Company's use of skilled English men at the earliest stage of development that provided an avenue to alternative mining methods, technologies and people than those typically adopted by American companies overseas. 


\section{CHAPTER 7}

\section{The Heritage Significance of Arctic Coal Company Remains}

\section{Introduction}

To this point, this study has analyzed the expansion and character of the Arctic Coal Company's network and compared it to contemporary American examples. This leads to the practical question: what is the heritage significance of the remains of the company on Spitsbergen's landscape today? To answer this, it is important to understand the historical significance of the company and then connect that with the physical remains still extant on the landscape.

The Arctic Coal Company made a fairly short lived and ultimately unprofitable effort at mining on Spitsbergen. At the same time, it was the first of several large-scale attempts that industrialized the archipelago, established its main settlements and impacted its current political and commercial makeup. Coal mining on Spitsbergen, viewed historically, is important because it was a powerful force in shaping the political, economic and social character visible today but what role did the Arctic Coal Company play in those changes? Was it simply one of a number of mining attempts or did it play a larger part? William Cronon's discussion of the environmental history of the Kennecott Mines provides a methodology to draw out the company's legacy on Spitsbergen through exploration of the relationship between the operations and the environment.

The overarching goal of this chapter is to support local efforts to manage the historic resources of the Arctic Coal Company. It does so by clarifying the heritage significance of the remains that future planning efforts can draw on. This outline of values may help 
prioritize future plans for restoration, maintenance or interpretation and help shape their form. They also could benefit discussions about more general town projects, such as utility changes or private construction proposals, by promoting outcomes that minimize negative heritage impacts and avoid sensitive areas. The analysis has no statutory authority on Spitsbergen, nor has the office of Spitsbergen's Sysselmannen (the governor) requested it from the author. Rather, these arguments are an outgrowth of the historical study on the company. They are offered as a perspective that the Sysselmannen may or may not chose to adopt or otherwise as that office chooses.

\section{Heritage Legislation on Svalbard}

The Svalbard Sysselmannen's (governor's) office, within the Norwegian Directorate for Cultural Heritage, is responsible for the protection of cultural heritage on Svalbard. As the management of Svalbard exists within the Spitsbergen treaty, Norway must consider the rights of all signatory nations in its actions. As such, Norway uses a unique legal framework for cultural heritage on Svalbard, separate to its policies for the rest of the country. The Sysselmannen manages cultural heritage under the Environmental Protection Act, 2001, which also outlines regulations for the management of Svalbard's natural environment. In 2007, the Norwegian Directorate for Natural Management and the Directorate for Cultural Heritage nominated the entire archipelago as a World Heritage Site and Svalbard is on UNESCO's tentative list today. As that nomination specifically cites historic coal mining remains as significant aspects of the archipelago, its world heritage listing may extend heritage protection for Arctic Coal Company the remains in line with world heritage standards. 
The Environmental Protection Act, 2001, defines cultural heritage as any trace of human activity and deems as protected those created on or before 1945, on private or public land. The Sysselmannen may also protect sites of particular cultural value dated after that time. Under this definition, the law provides automatic protection for all remains of the Arctic Coal Company. The act provides a 100 meter security zone around protected sites, restricting any potentially damaging activities and excluding camping. The Sysselmannen administers the act by enforcing strict archaeological excavation standards, forbidding physical interaction with items of cultural heritage unless with specially permission. The Act maintains that any proposal for human action that may affect significant environmental or cultural heritage features be accompanied by an approved environmental assessment that addresses the activity's impacts on the environment.

The act defines and protects cultural heritage only in the broadest terms and includes minimal mechanisms on evaluating significance and the impact today's actions will have on them. The act refers to heritage 'values,' including provisions for sites of 'particular heritage value' and deters actions that may 'reduce the historical value,' but provides no specific mechanism to guide evaluation of 'values,' nor a definition of it. The act affords the Sysselmannen the authority of evaluating and approving all potentially damaging activities, with the goal of minimizing or preventing damage to historic values, without identifying a process for how that evaluation should take place. While the Act establishes that the remains of the Arctic Coal Company are protected, it lacks the provisions necessary to understand their heritage values more deeply on which to base a larger heritage management and preservation strategy. 


\section{Evaluating Heritage Significance}

This project adopts the guidelines of the Burra Charter, 1999,432 of Australia ICOMOS (International Council on Monuments and Sites) for evaluating heritage significance as it provides an excellent description of the process of significance assessment and its implication in heritage policy. It also defines relevant heritage terminology and provides a methodology for heritage work including identifying appropriate people to perform such work and stakeholders in changes to significant places. While Australian organizations developed the charter, it is broadly applicable as a heritage philosophy to any site because of its flexible methodology and groups across the world have applied it in this way.

The Burra Charter is an overarching heritage philosophy that provides guidelines to the conservation and management of places of cultural significance. It places cultural significance centrally in the practice of heritage management, whereby "the aim of conservation is to retain the cultural significance of a place." 433 The charter advocates a heritage process whereby historical and site analysis form the basis for assessing cultural significance and policies and actions are then developed around the assessed level and character of significance. The following analysis follows this methodology. The term 'cultural significance' here correlates with the term 'value' in the Environmental Protection Act, 2001.

The Charter characterizes significance broadly, considering more than purely historical issues. Significance, its states, are the aesthetic, historic, scientific, social or spiritual 432 ICOMOS Australia, The Burra Charter: The Australia ICOMOS charter for the conservation of places of cultural significance 1999 (Canberra, Australia: Australia ICOMOS, 1999), article 1.2 and Article 2.

433 Ibid., Article 2.2. 
values for past, present and future generations. This approach provides flexibility in illustrating the various values of a place, whatever they may be. Aesthetic values are those related to sensory perception, including the shape and form of structures and their landmark qualities to the surrounding area. Historic values may relate to the site of an important historical event, or have been influenced by or influenced an important historical person or event. Scientific value denotes a place's ability to yield further substantial information. Social value relates to the importance a site or object holds to a specific group, regardless of its other values. 434

The analysis of significance provided here is a partial account of all the values associated with the places featuring Arctic Coal Company remains when considered under the Burra Charter. This work does not consider the values of remains associated with the many different groups that operated in the same locations of the Arctic Coal Company. Store Norske Spitsbergen Kulkompani, for instance, adopted the Arctic Coal Company's operations in Longyear Valley, expanding them and changing them over time. A complete assessment of the historic remains of Old Longyear City would need to consider the history of Store Norske Spitsbergen Kulkompani there. The analysis also does not consider the social value of the company's remains to local or international groups. Heritage efforts should allow the people for whom a place has significance to participate. 435 The above being true, the analysis draws on enough historical research and field work to provide a good understanding of a large part of the significance values and further research into other histories and social values is likely to only expand and enhance the analysis provided here.

434 Australia ICOMOS, Guidelines to the Burra Charter, article 2. 435 Ibid., article 11. 


\section{Historic Significance of the Arctic Coal Company's efforts}

The Arctic Coal Company's effort has historical significance for several overlapping reasons. This section details the paramount points of significance, related to the company's place in Spitsbergen's coal and mineral rush and its influence on the later shape of Spitsbergen's social political economy.

\section{The First Major Coal Mining Operation on Spitsbergen}

The Arctic Coal Company is historically significant as the first fully operational, industrial scale mining operation on Spitsbergen, the leader of a string of operations that followed. Prior to its arrival, only small mining groups had attempted mining on Spitsbergen. The Trondhjem-Spitsbergen Kulkompani, the Bergen Spitzbergen Kulgrubekompani, Kulgrubekompagniet Isefjord-Spitsbergen, the Bergenske Kulkompagnie and others consisted of a small group of men that created small mine openings or small test pits and claimed lands. While they helped lay the foundation for others, none constructed significantly sized, ongoing operations or delivered large quantities of coal to market.

One possible exception is the Spitsbergen Coal \& Trading Company's operations on Advent Bay, which made the largest attempt at mining immediately prior to the Arctic Coal Company. From 1904-1908, that company erected Advent City with over a dozen well built log homes, an incline tramway, powerhouse, simple dock and mine across the bay from Longyear City. ${ }^{436}$ The difference between this enterprise and that of the Arctic Coal Company is that while the Spitsbergen Coal \& Trading Company had a settlement and equipment, it failed to develop an operation. The company never developed a fully

436 West, Ian and Miles Oglethorpe, Advent City in: Martin, Patrick et. al., Industrial Heritage in the Arctic, 33-50. 
operational mine, mined and sold little coal, failed to develop a market for coal and only gained a reputation for poor quality in Norway, and made little progress in prospecting and understanding the coal geology of its claim. It also invested far less than the Arctic Coal Company on their operations. This is important because one of the key conclusions arising from the analysis of the Arctic Coal Company's technical system is that the company only really began to face the major issues of building a coal mining network on Spitsbergen after it had begun full operations. The Arctic Coal Company distinguishes itself against its contemporaries because it was the first to confront the deeper operational issues of mining on Spitsbergen and made progress in developing a network that rationalized them.

\section{Part of Spitsbergen's Longest Lived Coal Mining Effort}

From 1900 through to today, three closely connected and sequential companies explored the southern Advent Bay landscape and surrounds and developed plans for expansion and development: The Trondhjem-Spitsbergen Kulkompagni, the Arctic Coal Company and Store Norske Spitsbergen Kulkompani. Rather than being three separate companies that changed in ownership as they met commercial failure, they characterize a continual, evolving effort that expanded and adapted with new investment capital. This lineage represents the longest running mining effort in the archipelago's history, which participated in many of the most important historical events on Spitsbergen since the beginning of the twentieth century and continues today, although in a minor way. The results of this ongoing effort had major implications for how people interact with Spitsbergen today and the significance of the remains of each stand partly in the context of the continual evolution of all three. 
The three companies' fairly unified attempt to develop the Ice Fjord landscape is visible in their commercial strategy, the people involved, and their operations. Commercially, both the Trondhjem-Spitsbergen Kulkompagni and the Arctic Coal Company pursued a deliberate strategy to investigate and develop Ice Fjord lands to attract larger investment capital. Both succeeded in doing so and thus the sequence of ownership represents the successful accomplishment of this goal, although at a small profit or financial loss.

Stockholders and employees of each company carried into subsequent organizations. Some of the founding members of the Trondhjem-Spitsbergen Kulkompagni continued their investment interest through both the Arctic Coal Company and Store Norske Spitsbergen Kulkompani times and Ayer and Longyear each took stock in the new company as a sizeable portion of their payment at sale. 437

Finally, each company built upon the efforts of its predecessor. While both the Arctic Coal Company and the Store Norske Spitsbergen Kulkompani expanded the existing works, they did so on the basis of the knowledge of their predecessors and within their general conception of future development. This environmental continuity is particularly relevant to the remains on Tract \#1, on Advent Bay, which saw continual exploration, development and exploitation by these companies through today.

\section{The Arctic Coal Company's Legacy on Spitsbergen}

Arguments in chapter 3 showed that one of the Arctic Coal Company's goals, to profit from their land claims through increased commercial interest in Spitsbergen's coal lands, largely failed to be realized and the claims lay in the background at the final sale of the company. In contrast, the company made considerable progress with its mining

437 Dole, America in Spitsbergen, ii, 423-425. 
network on Advent Bay. To understand the Arctic Coal Company's legacy on Spitsbergen, one must consider the extent that the Store Norske Spitsbergen Kulkompani adopted its operations and efforts, and the influence the Arctic Coal Company had on other mining groups on the archipelago.

\section{Legacy to the Store Norske Spitsbergen Kulkompani}

In developing an operation on Spitsbergen, the Arctic Coal Company connected technologies, markets, environmental features and people together in a particular and complex way. When the Store Norske Spitsbergen Kulkompani bought the operations, it faced the decision of continuing and adapting the existing system or reinventing a new approach to using landscape. The Arctic Coal Company had not been profitable but to abandon the existing approach would be very expensive and risky. The extent that the new company continued the Arctic Coal Company's current system and proposals for future growth, and its relationship to the make up of the Advent Bay area today is central to understanding the operation's legacy. William Cronon's environmental history of the Kennecott mines offers a method for understanding how the different elements of the Arctic Coal Company related with the Spitsbergen landscape and the extent that Store Norske Spitsbergen Kulkompani continued or diverged from that. 438

Cronon's environmental history framework for describing the "political economy of people as social beings reshaping nature and one another to produce their collective life” 439 shows the particular way the Kennecott Copper Company tied itself to the environment. Unlike its native neighbors, the company interpreted and adapted the

438 Cronon, "Kennecott Journey: The Paths out of Town."

439 Ibid, 32. 
environment within a capitalist mindset. It made land boundaries and secured ownership over them through the Alaskan legal system. It used science to understand the geography and geology of the landscape. It built transport systems and developed trade networks to support the flows of goods and people between the mine and the outside world. It developed a settlement that expressed specific capitalist social relations necessary for the operations. ${ }^{440}$ The technical systems that translated minerals into a commercial product could easily be added to this list. In all the ways described, the company's operations tied humans and human systems to the local landscape, and this place with the outside world.

The Kennecott Copper Company example very closely resembles the Arctic Coal Company's relationship with its environment. The difference between the two companies is that the former worked until it judged the ore body mined out and abandoned the area while the latter sold its works to a new group, and the factors highlighted, the land definition, transport systems, trade links, settlement, scientific landscape interpretation and technical system, were passed on. In other words, the Store Norske Spitsbergen Kulkompani purchased an existing relationship with the Advent Bay environment, that defined where and how to mine, how to transport coal, how to operate in the Spitsbergen climate, knowledge of the landscape, reputation to outside markets, and the character of the workforce.

In the earliest years, Store Norske Spitsbergen Kulkompani continued using the mining operations and settlement of the Arctic Coal Company. It mined the same mine, even

440 Ibid, 43-48. 
working the same areas already prepared using the same methods, ${ }^{441}$ and stored and transported the coal, as predecessors had done, until 1920 when mine 1 blew up, killing twenty six miners and destroying the mine. ${ }^{42}$ Longyear City also continued to be the major settlement and is today the capital and largest community of the archipelago. It is not surprising that Store Norske Spitsbergen Kulkompani would continue using these elements because they offered a point of immediate departure and afforded them time to find their feet and plan for the future. What is surprising is the extent to which the company pursued the Arctic Coal Company's plans for the area.

By 1913, the Arctic Coal Company had begun to see the limited lifespan of its existing operations and started outlining future directions. Geological investigations confirmed the limited commercial value of the Mine 1 area 443 but Turner found two areas of greatest future mining potential lay across Longyear Valley, one at the site of mine \#2 and another further south of that. 444 General Manager Scott Turner argued that the company needed a new powerhouse 445 and coal storage system. He advocated an overhead travelling crane to efficiently distribute and reload coal but designed a smaller

441 'Grube Nr. 1' (plan of Mine 1 in 1921), Statsarkivet i Tromsø, Store Norske Spitsbergen Kulkompani Collection, box 3896.

442 Dole, America in Spitsbergen, ii, 434.

443 Arctic Coal Company General Manager's Report Covering Operations during the year 19121913, Michigan Technological University Archives and Copper Country Historical Collections, Scott Turner Collection (MS-018), box Z, folder Z39.

444 Scott Turner states in a letter to geologist Drummond MacGavin that his prospecting work confirms that mine 1, mine 2, and south of mine 2 (later mine $2 \mathrm{~b}$ ) are the most important areas for development around Longyear City, January 8, 1913, Michigan Technological University Archives and Copper Country Historical Collections, Scott Turner Collection (MS-018), box CB, folder CBo4.

445 Arctic Coal Company General Manager's Report Covering Operations during the year 19121913, Michigan Technological University Archives and Copper Country Historical Collections, Scott Turner Collection (MS-018), box Z, folder Z39. 
adaptation of the existing system as an interim measure. ${ }^{446}$ Turner also had vague notions about Advent Point's harbor for shipping and had a hydrological and topographical survey of that area made. ${ }^{447}$ From both the network and environmental history perspective, these proposals grew from years of experience and development on Advent Bay that were intended to enhance of the company's relationship with the environment.

Store Norske Spitsbergen Kulkompani's development of the Advent Bay landscape shows striking similarities to all Arctic Coal Company development proposals and thereby continued the Arctic Coal Company's relationship with the environment. In the early 1920 , it constructed a new powerhouse and formally exploited mine \#2, storing its coal on Advent Point with a large overhead crane and shipping from the adjacent harbor. ${ }^{448}$ In 1937, it opened mine \#2b as its next mining location, further south of the valley in the place where Turner had suggested. 449 The Store Norske Spitsbergen Kulkompani also maintained other aspects of the operations. It continued to mine coal seam \#2, the Longyear Seam, which the Arctic Coal Company identified as the most commercially viable of the four seams available. ${ }^{40}$ It continued using and expanding Longyear City until the Germans burnt down the town during World War II, when it rebuilt the town

446 Arctic Coal Company General Manager's Report Covering Operations during the year 19111912, Michigan Technological University Archives and Copper Country Historical Collections, Scott Turner Collection (MS-018), box Z, folder Z13.

447 Combined Topographic and Hydrographic Map of Portion of Advent Point, Map 94, Michigan Technological University Archives and Copper Country Historical Collections, Scott Turner Collection (MS-018), box BU.

448 Westby, Sigurd, Store Norske Spitsbergen Kulkompani, 1916-1945, edited by Birger Amundsen (Longyearbyen, Norway: Store Norske, 2003).

449 "History / The Mines / Mine 2," Store Norske Group Homepage, <http://www.snsk.no/internet/> (May 7, 2009).

450 Ibid. 
nearby. ${ }^{451}$ It also retained the services of the Arctic Coal Company's accountant, Carl Saether; employed its superintendant, Kenneth Gilson, to take charge of the mine; and asked former Arctic Coal Company officials for advice on mining and machinery. 452

The Arctic Coal Company had a strong impact on the first decades of the Store Norske Spitsbergen Kulkompani and left its legacy in the ongoing and evolving human relationship with the environment from that time forward. From 1916 through today, the southern Advent Bay area gradually evolved from its Arctic Coal Company roots. Even though few of the Arctic Coal Company's facilities remain in use, the company has a large legacy for the area today because it represents the foundation of the ongoing and evolving modern human relationship with this environment. Economic theorists and social scientists observe this as a common pattern of change known as 'path dependency.’ 453 Developments in areas such as technology, economics and science relate strongly to existing knowledge, tools, infrastructure and people, which make progress in one direction much easier and more likely to occur.

\section{Legacy to other Spitsbergen Mining Operations}

The Arctic Coal Company's operations left a wider legacy for the archipelago as it served as an encouragement to other groups and a model of development. At least two other coal mining companies mimicked the mining and development strategy of the Arctic Coal Company on Spitsbergen. In 1913, a Russian company from St. Petersburg settled and claimed the western section of the Arctic Coal Company's Tract \#1, today called

451 Arlov, Thor B., A Short History of Svalbard (Oslo: Norsk Polarinstitutt, 1989),75-76.

452 Dole, America in Spitsbergen, ii, 425.

453 Rosenberg, Nathan, Exploring the Black Box: Technology, Economics, and History (Cambridge University Press, 1994). 
Grumantdalen. In 1914 they consulted the Sullivan Machine Company, located in Britain, asking them for a complete set of mining equipment that exactly duplicated that of the Arctic Coal Company. 454 The company never got the chance to use the equipment but returned to that location some years later and developed a sizeable mining operation.

In 1913, a Swedish team under J. B. Atkinson investigated the viability of opening a mine on Braganza Bay, south-east of Advent Bay. Atkinson prepared a report on the best approach to developing a mine and the expected results and costs. 455 His report made particular reference to the Arctic Coal Company's approach to mining in Longyear Valley and interviews with Scott Turner, and drew inspiration for many facets of the proposal from them. The most notable examples are his suggestion to use the room-and-pillar mining method, preferred by Turner, with the aim of extracting around 50,000 tons each year, roughly equivalent to the experience of the Arctic Coal Company. He suggested a similar coal storage and delivery system where the company would store coal outdoors over the winter and rapidly re-load coal using steam cranes. He also considered a small coal hopper at the mine site. The greatest diversion from the Arctic Coal Company model was his suggestion of moving coal via a surface rail line to save on cost. At first, the company pursued that idea but upon finding difficulty in moving coal in snowy, cold conditions, adopted the Arctic Coal Company's approach of using an aerial tramway system. 456

454 Dole, Nathan Haskell, America in Spitsbergen, $\ddot{i}, 333$.

455 Atkinson, J. B., Spitsbergen Coal, 1913, report for the Isfjorden-Belsund Company, 1913, Riksarkivet, Spetsbergenarkivet, Vol. 4, Stockholm. 456 Avango, Sveagruvan, 191-202. 


\section{Summary of Historical Significance}

The Arctic Coal Company has major historical significance, mostly centered on its activities at Advent Bay. Its mining operations in Longyear Valley were the first industrial scale mining operations on Spitsbergen and the first to confront the realities of mining in this high-Arctic location. Its work on Advent Bay played a major part in a continual effort to develop that area by three successive companies, the longest continual effort in Spitsbergen's history. The company left a major legacy in Advent Bay since the Store Norske Spitsbergen Kulkompani adopted its operations and pursued its plans for growth, and since considerable aspects of the area today resulted from the evolution of the human relationship with the environment established by the Arctic Coal Company. The operation had a wider consequence for Spitsbergen as it also served as an encouragement to other groups to attempt mining and as a model of development for at least two companies, and because Longyear City became the capital and administrative center of the archipelago.

At least one study supports the above assessment of the Arctic Coal Company's operation's legacy to the Store Norske Spitsbergen Kulkompani and wider coalfield development. In conclusion to their description of the Arctic Coal Company's activities, the authors of Store Norske 75 år write:

"In 1915 the facility at Longyear Valley had come up to a level where the owners deemed it feasible to make a profit. The Americans had proven it to be possible, and in this way Arctic Coal Company became a locomotive for the continued efforts in coalmining that followed the First World War. It is difficult to imagine that such a development would have taken place without the Arctic Coal Company. Finally, the activities of Arctic Coal Company were the reason for, and became the foundation for Store Norske." 457

457 Arlov, Thor B. (ed.), Store Norske $75 \AA ̊$, 54 . Translation by Ulf Gustafsson. 
The Arctic Coal Company's work on its four land claims, outside its Advent Bay operations, have more moderate historical significance. They helped define the land parcels and expanded knowledge of the coal resources of the Ice Fjord. They represent a strategy to influence and profit from the widespread development of the coal fields. They also participated in an important historical activity on Spitsbergen, coal mining.

\section{Significance of the Physical Remains of the Arctic Coal Company}

Four seasons of archaeological survey across the former Arctic Coal Company lands of Spitsbergen found extensive evidence of all types of activities performed by the company on the landscape. Michigan Technological University (MTU) has worked in collaboration with European universities and organizations on Polar industrial history under the research framework of LASHIPA since 2004. Students and staff of MTU concentrated on recording and interpreting the historic remains of the Arctic Coal Company with assistance from other members of LASHIPA while reciprocating with the research goals of other members. Michigan Technological University representatives recorded almost all the remains of the Arctic Coal Company in archaeological surveys of 2004, 2006, 2007 and 2008, which provides an excellent basis of understanding the extent and nature of those remains and, alongside historic research, their heritage significance (bibliography lists the reports that document those surveys.) The following sub-section assesses the significance of the remains first as a complete group and then as smaller groupings of remains of like type.

\section{Historic Significance of the Remains as a group}

The Burra Charter states under its definition of Historic Significance that "for any given place the significance will be greater where evidence of the association or event survives 
in situ, or where the settings are substantially intact, than where it has been changed or evidence does not survive." ${ }^{58}$ The surveys showed a very high rate of survival of Arctic Coal Company remains in situ, in conditions ranging from standing structures to ruins and surface remains. At the minimum, significant parts of the company's entire exterior industrial system, its settlement, transportation facilities and claim / prospecting huts are visible today and testify to the full range of activities the company undertook here.

Five structures remain standing, four of which are still in use today. These include the Mine 1 coal hopper, the dock, warehouse \#4, a hut on Cape Boheman 459 and a hut at Elveneset on Sassen Bay. Part of the surface plant at mine 1 also remains standing. The bulk of the company's prospecting pits remain intact with original walls or as simple pits that are easily interpretable by informed observers. Other remains exist as surface features that, for the most part, are visible and easily interpretable by informed observers.

In accordance with the Burra Charter, the relative completeness of the Arctic Coal Company's physical interventions on the landscape lends significance to the whole group of remains. The collection speaks to the broad range of activities of the company and exemplifies its full historic significance, described above. This means that all company remains, regardless of historic use, size or condition, have significance in their association with a highly significant collection of remains and should be protected. The loss of any component of the group would damage the integrity of the collection and thereby reduce its significance.

458 Burra Charter, Section 2.3, 12.

459 The Arctic Coal Company did not construct the hut on Cape Boheman but claimed it as part of the land claim and used it as a base for prospecting the landscape. 


\section{Significance of Individual Parts of the Remains}

In addition to the significance of the remains as a collection, smaller groups of remains have significance in their individual relationship to Spitsbergen's history. This section examines groups of like kind, expands on the discussion of their historical significance and provides insight into the level of significance of each.

\section{Remains of the Company's Land Claims}

Extensive evidence remains of the Arctic Coal Company's land claiming and geological surveying activities across the Ice Fjord. Figure 7.1 shows the location and status of Company huts around the Ice Fjord. Most exist as ruins or as foundations and two still stand. Only one hut, formerly located on Green Harbor, is no longer visible on the landscape. Later road construction likely covers those remains. Archaeologists are yet to definitively identify the hut remains on the east side of the Sassen Bay claim (Tract \#3) as coming from the Arctic Coal Company. Archaeological surveys identified prospecting pits at Cape Boheman (Tract \#4) and Green Harbor (Tract \#2) associated with the Arctic Coal Company and competing groups working there. 


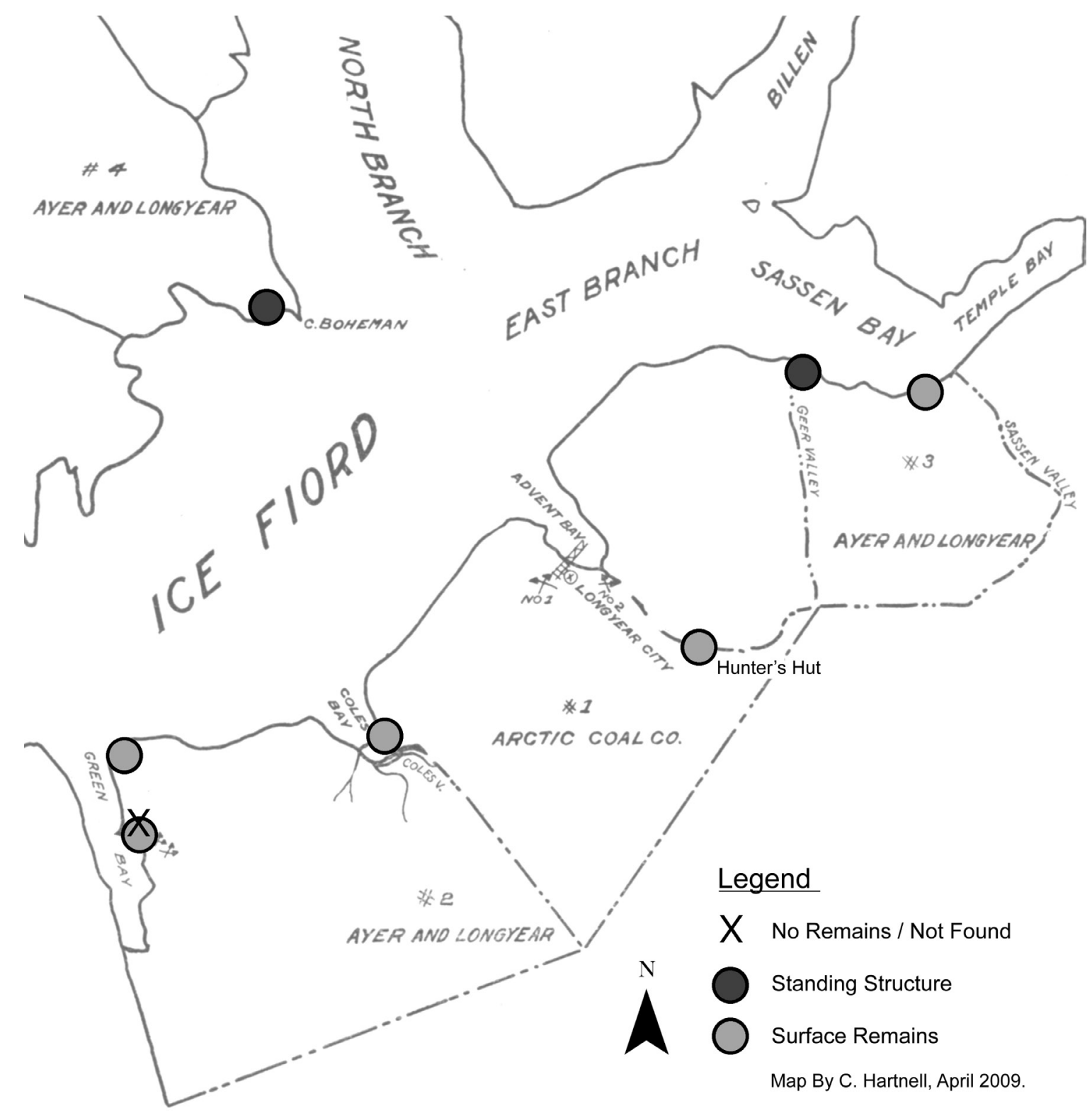

Figure 7.1 Map showing the status of Arctic Coal Company claim huts across the Ice Fjord, leaving out the main developments of the company on Advent Bay. Evidence of most huts remain on the landscape and two still stand today. Map by C. Hartnell, based on map from the Michigan Technological University Archives and Copper Country Historical Collections, Michigan Technological University, Keweenaw Digital Archives, MSo31-02-12-01.

The Arctic Coal Company huts served a functional and political purpose for the company. They speak to J. M. Longyear's ambitious strategy to direct the development of Spitsbergen's mineral lands, still visible in the private land holding pattern there today. 
Most huts supported coal prospecting activities by providing living and storage space for teams to work nearby coal seams. They also supported symbolic objectives by asserting the land claims to outside observers. The company used evidence of their huts, as well as signs and other activities and physical materials, in political discussions over the archipelago as evidence of their use of their land claims and their rights to maintain those claims. Few Arctic Coal Company claim signs remain on the landscape. The author knows of only one possible company claim sign that stands on the north-east end of the Sassen Bay claim (Tract \#3), in the general vicinity of the company's possible hut remains. No text remains on the sign, making it impossible to positively define its origins.

As per the analysis of historical significance above, the evidence of the company's claiming and prospecting activities have moderate historical significance.

\section{Remains at Green Harbor}

Archaeological surveys have confirmed the rich legacy of physical remains of Arctic Coal Company activities at Green Harbor. These remains speak to Ayer and Longyear's attempt to profit from their land claims with increased commercial interest in the region and the intense commercial and political struggle over control of this area. The Arctic Coal Company viewed Tract \# 2, particularly around Green Harbor, as its second most valuable land tract and invested time, effort and capital to prospect its resources and develop a basic foundation for future development. From 1913, the company attempted to lease or sell this tract separately from its Advent Bay negotiations but ended up selling it together with all other land claims. Figure 7.2 shows that evidence of most of these activities remains today. Two hut sites remain as surface remains, one north of the map 
area. Both company mines there remain in reasonably good condition with entry walls still standing and associated artifacts. ${ }^{460}$ Figure 7.3 shows the status of Green Harbor Mine 1 in 2007. Perhaps the majority of its prospecting efforts remain on the landscape, mostly indistinguishable amongst the coal testing efforts of numerous other competing companies that worked here.

Missing from the company's story on Green Harbor are the company's short-lived activities on the shoreline, downhill from its barrack. Archaeological surveys found no evidence of a hut there that the company purchased from Lars Iversen in 1908, nor of the temporary coal pile and simple wharf constructed in 1914 used to transport all its coal mined here since 1909.

Since Green Harbor was the site of the second most important operations of the Arctic Coal Company, was the most successful part of Ayer and Longyear's efforts to claim, and open new mining areas, and because it survives reasonably intact, the remains here have medium-high historical significance.

460 Aalders et al., LASHIPA 4, 59-60. 


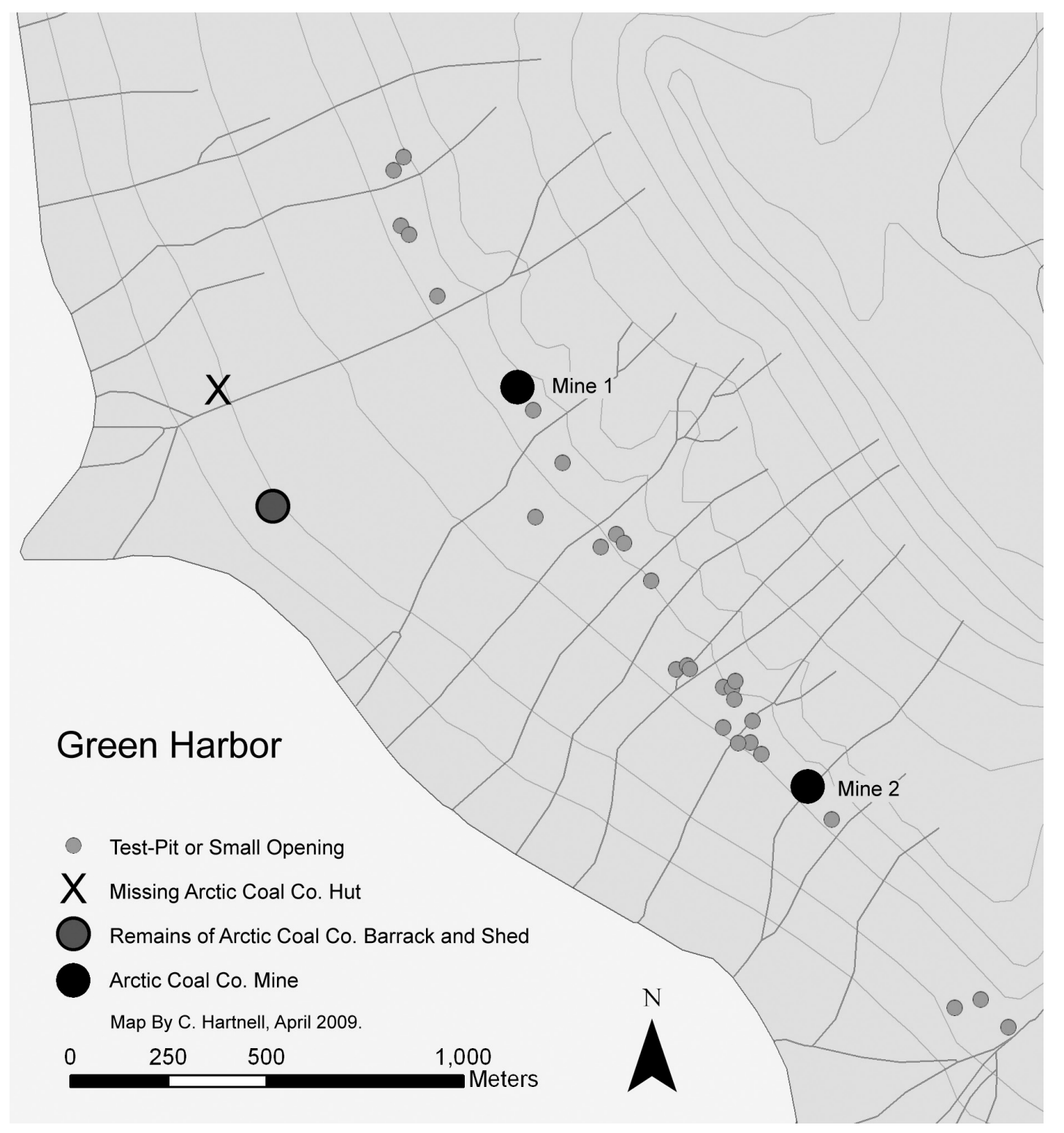

Figure 7.2 Map of results of MTU/LASHIPA archaeological surveys at Green Harbor showing test-pit and mine openings, the two Arctic Coal Company mines and two Arctic Coal Company huts, one missing, over looking Green Harbor. The surveys located the site of another Arctic Coal company hut on the north-east corner of the harbor. Map by author using MTU/LASHIPA survey data and Norsk Polarinstitutt base map information. 


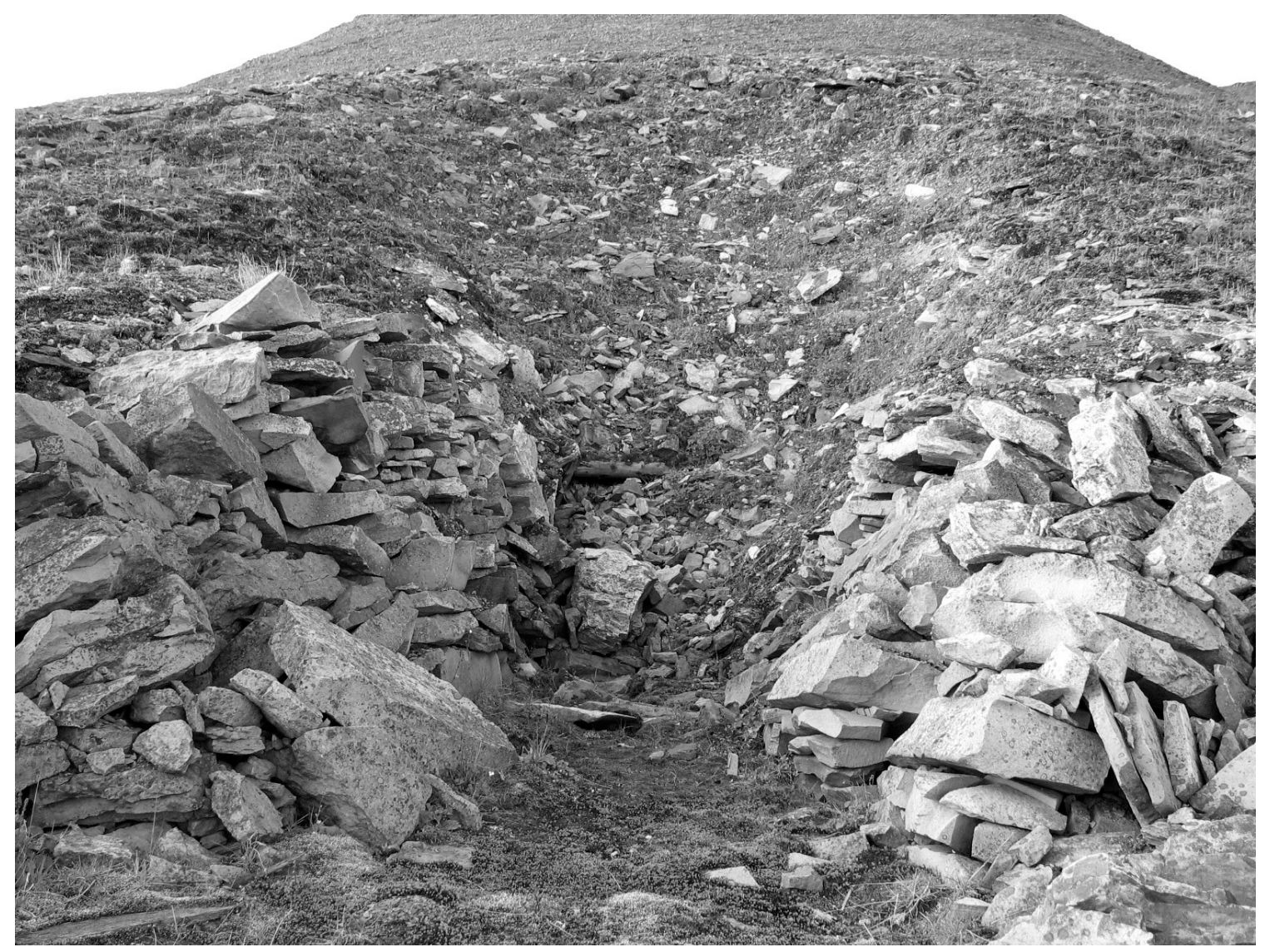

Figure 7.3 Photograph of the south entry to Green Harbor Mine 1 from above, taken by author in 2007. While collapsed soil and rock have closed the entry, its walls remain standing in good condition. Artifacts and remains in the vicinity testify to the former function of this mine.

\section{Remains of Geologic Testing and Mapping on Advent Bay}

Figure 7.4 shows the extensive remains relating to the Arctic Coal Company's geologic testing and mapping activities around Advent Bay. These remains have medium-high significance because they were an important part of the Arctic Coal Company's intensive efforts to develop this land tract, on which the company and perhaps their successor based many development decisions, which mostly survive in fair to good condition. The remains are associated with the exploitation of this area from the 1870 , were part of the 
most intensive mapping and commercial geological survey in the area and one of the most intensive ever undertake on Spitsbergen to that time.

The figure shows 55 test-pits and openings remaining on the landscape here, excluding mine entrances. The Arctic Coal Company created most of them but a few stem from James Lamont's mining, the Trondhjem-Spitsbergen Kompagni's testing and mining efforts, and Store Norske Spitsbergen Kulkompani's efforts, some of which overlap. Also shown are four Arctic Coal Company survey benchmarks, used to map the area. A few more test-pits and survey markers remain to be documented. Constructed as either basic structures or simple pits, the majority are reasonably intact and are easily interpretable by an informed observer.

In 1912 and 1913, the company undertook a major geological survey of the area, around $1 / 7^{\text {th }}$ of its Tract \#1, to establish the extent and quality of coal reserves here based on a scientific methodology. This was one of the most detailed geological survey of Spitsbergen's coal resources ever undertaken and the most detailed for this area. ${ }^{461}$ In conjunction with this, the company undertook a detailed mapping project of that area that presented the geographical features of the area and all the relevant cultural features on it. The maps resulting from this work were the most detailed maps produced of the area and one of the most detailed ever made on Spitsbergen to that time. ${ }^{462}$ Both the geological survey and mapping efforts formed essential parts to the company's attempt

461 Geological Report by Drummond MacGavin, November 19, 1913. Michigan Technological University Archives and Copper Country Historical Collections, Scott Turner Collection (MS-018), box Z, folder Z14.

4621912 map of the Arctic Coal Company's operations on Advent Bay by Thomas H. Moncure, Michigan Technological University Archives and Copper Country Historical Collections, Scott Turner Collection (MS-018), box Z, folder Zo6. 
to prepare the area for full commercial scale mining and the marketing of the land to outside investors.

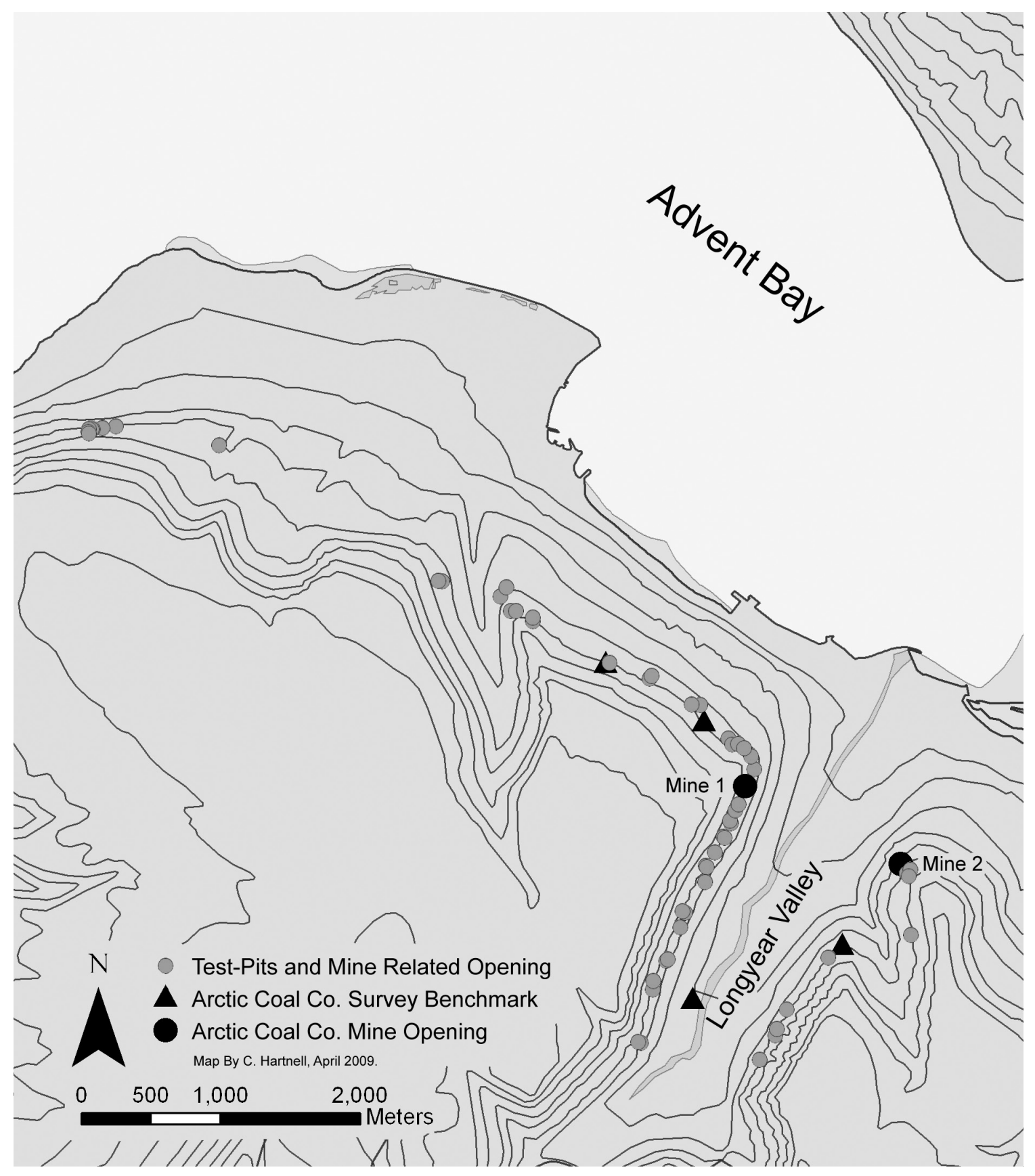

Figure 7.4 Map showing test-pits and survey benchmarks around Advent Bay located by the Michigan Technological University/LASHIPA archaeological surveys. Map By Author, April 2009, using MTU/LASHIPA survey data and Norsk Polarinstitutt base map information. 


\section{Old Longyear City}

Figure 7.6 provides a map that shows the evidence of Old Longyear City visible on the surface today. No structures from the Arctic Coal Company period still stand because the German military burnt the town during World War II, seen in Figure 7.5. ${ }^{463}$ Later development stands over sections of the town, obscuring them from view. Prior to WWII, Store Norske Spitsbergen Kulkompani continued to expand the town, occasionally building over some Arctic Coal Company structures. After the war, the city ran a road through the site, covering its mid-section with road fill. Later, the Sysselmannen built a settlement and government office over the small north settlement and other groups constructed some structures over the northern end of the Old Longyear City remains. Combined with the remnants of the later Store Norske Spitsbergen Kulkompani construction, the remains of the city are readily identifiable and the Sysselmannen promotes Old Longyear City as a local historical attraction with some on-site interpretation.

In line with the analysis of historical significance above, the remains of Old Longyear City have very high historical significance as it was an important component of the Arctic Coal Company's operations, represents the origins of Longyearbyen, the largest settlement on Spitsbergen and its administrative capital, and evidences the German attack on Spitsbergen in World War II. Heritage efforts should focus on preservation of the remains as they are today, including active management of human interaction with the remains to minimize negative impacts. No new construction should be permitted over the undeveloped section of Old Longyear City and should be minimized as much as is practicable over the partly developed northern area. Interpretation works are

463 Arlov, A Short History of Svalbard, 75-6. 
encouraged if they improve visitors' access to the history of this place and attempt to enhance the significance of the remains. Any interpretation works should be carefully planned to avoid damage to historic structures and manage artifacts appropriately. Interpretation work should also leave the undeveloped section of the city as open and visually unobstructed as possible as a reminder of its destruction in World War II. The area is likely rich with archaeological remains relating to Arctic Coal Company and Store Norske Spitsbergen Kulkompani occupations, which may reveal much new historical information. Should archaeological excavation proceed, it should carefully consider all historical values of this place, build upon existing archaeological work ${ }^{464}$ and be carefully planned to avoid any unnecessary loss of cultural materials.

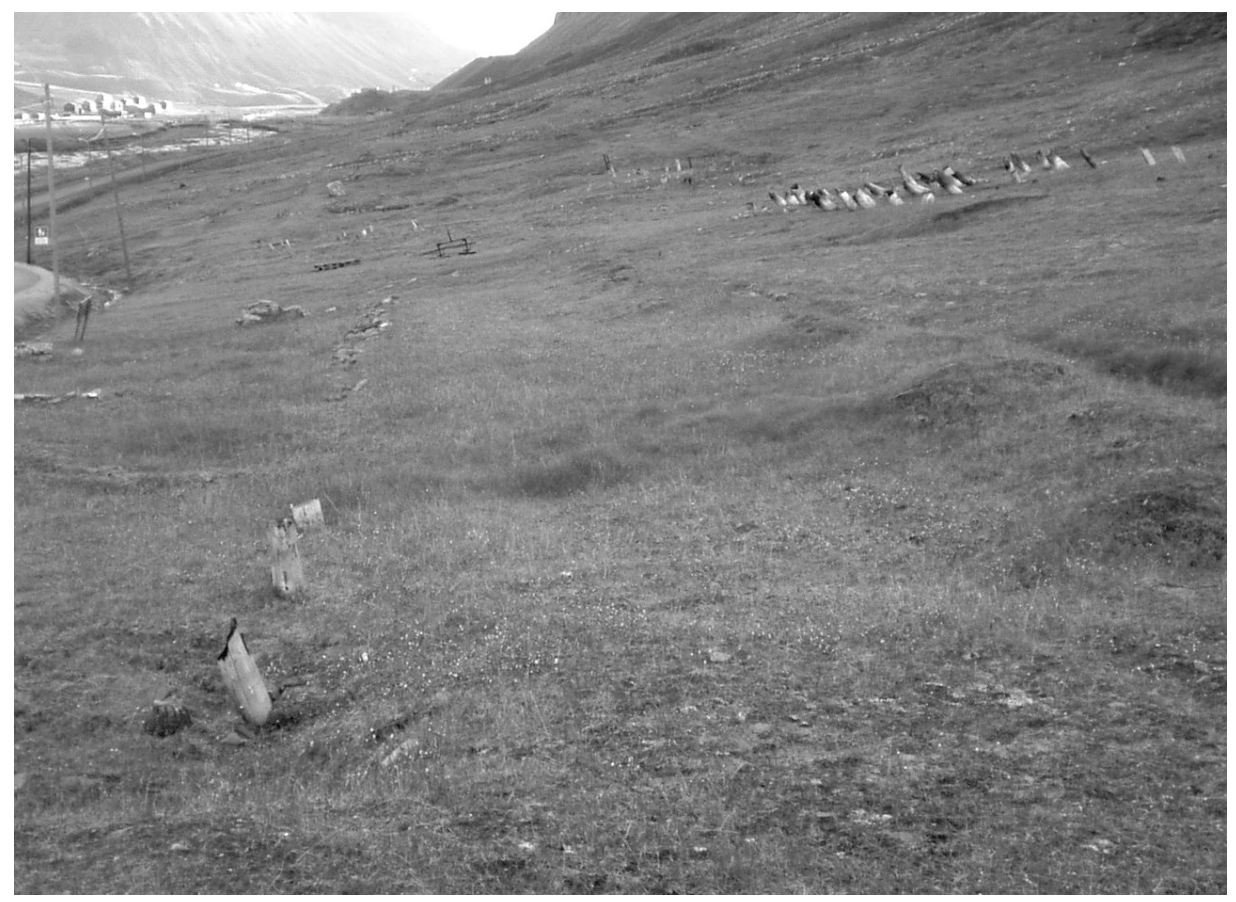

Figure 7.5 Photograph of southern part of Old Longyear City in 2003, by Patrick Martin/MTU. Note the foundation poles which show evidence of the town's destruction during World War II.

464 Future archaeological work should incorporate the efforts of LASHIPA from 2004-2009 to avoid duplication and confusion, and ensure the greatest possible knowledge of the area is adopted. 


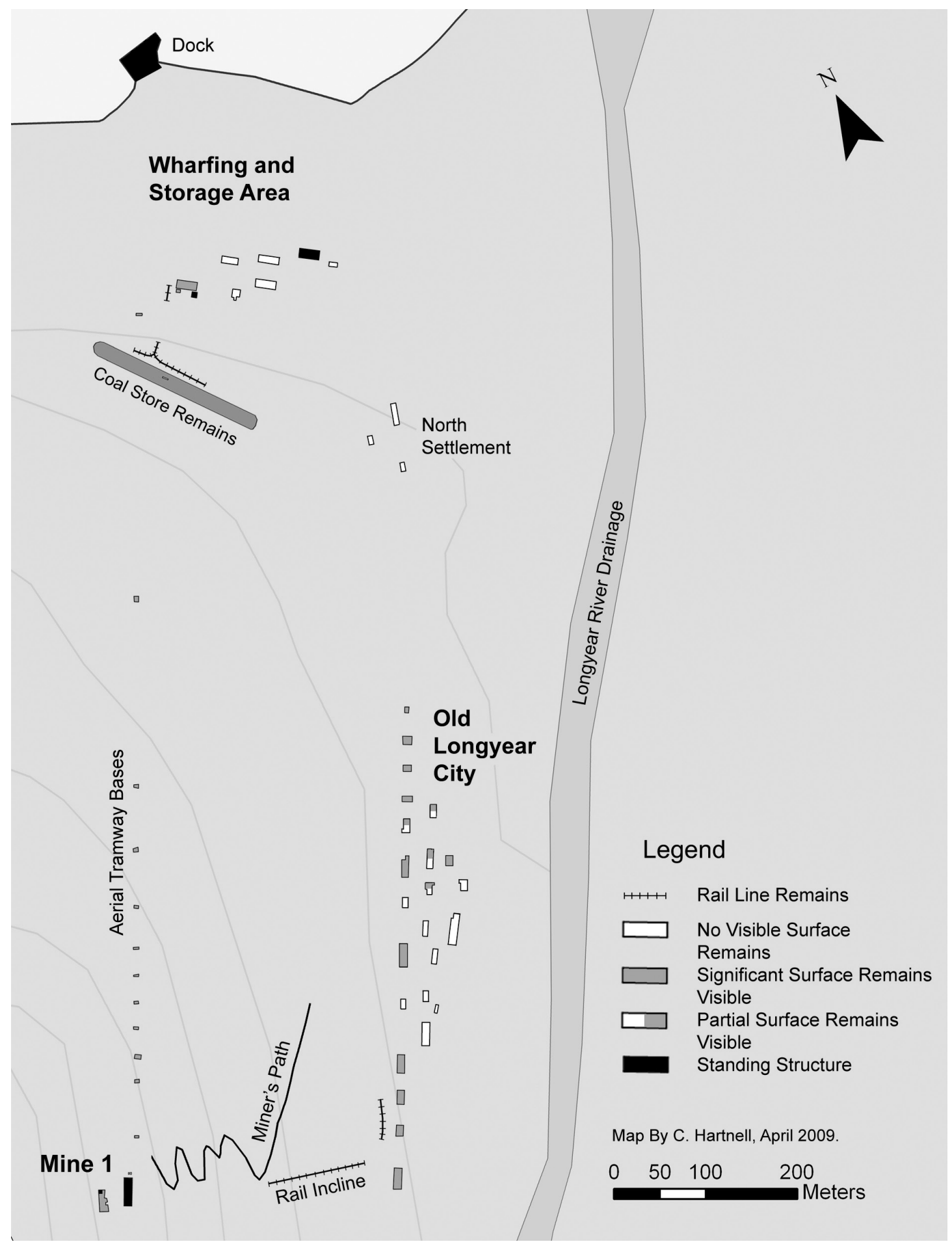

Figure 7.6 Map showing the remains of the Arctic Coal Company in Longyear Valley visible today. While much of the technical system is still visible, the buildings exhibit a patchy survival rate. Map by author, April 2009, using MTU/LASHIPA survey data and Norsk Polarinstitutt base map information. 
The small north settlement has little to no significance as later construction has hidden or removed all evidence of it. Future work should check for any possible impacts on historic remains here before proceeding.

\section{The Technical System}

The technical system associated with mine 1 has very high significance because it speaks to the core elements of the company's historical significance and because extensive evidence of the entire system remains on the landscape, including the largest number of standing structures of any part of the company. They are important as the first industrial scale and most extensive mine operations of Spitsbergen's early coal and mineral rush, which other operations looked to as a model for development. The mine also shows clear evidence of the explosion in 1920 that killed 26 workers. 465

Four components of this system still stand today: the coal hopper, the power stations condenser foundation, warehouse \#4 and the end of the dock. The mine, coal hopper and aerial tramway are local landmarks that stand clearly visible on the hillside to observers and from Longyearbyen below. A small part of the mine's surface plant also still stands while the rest is debris and structural sections that somewhat resembling its postexplosion form. ${ }^{466}$ The condenser foundation today serves as a storage space, the warehouse continues to store goods and the dock remains active in the port. All the bases of the aerial tramway are still in place and relatively visible on the mountainside running from the mine. The wharfing and storage area exhibits the greatest disturbance

465 Dole, America in Spitsbergen, ii, 434.

466 Photograph of the Mine 1 surface plant in 1920 after the explostion by Sigurd Westby in Westby, Sigurd, Store Norske Spitsbergen Kulkompani, 1916-1945, edited by Birger Amundsen (Longyearbyen, Norway: Store Norske, 2003), 184. 
of this group as no surface remains exist for four warehouse structures and the engineer's house. ${ }^{467}$ The Sysselmannen's office excavated the floor of warehouse \#2 in 2007, which a developer slated to demolish in 2008. The city has land-filled and developed much of that area, under which some physical remnants may still remain.

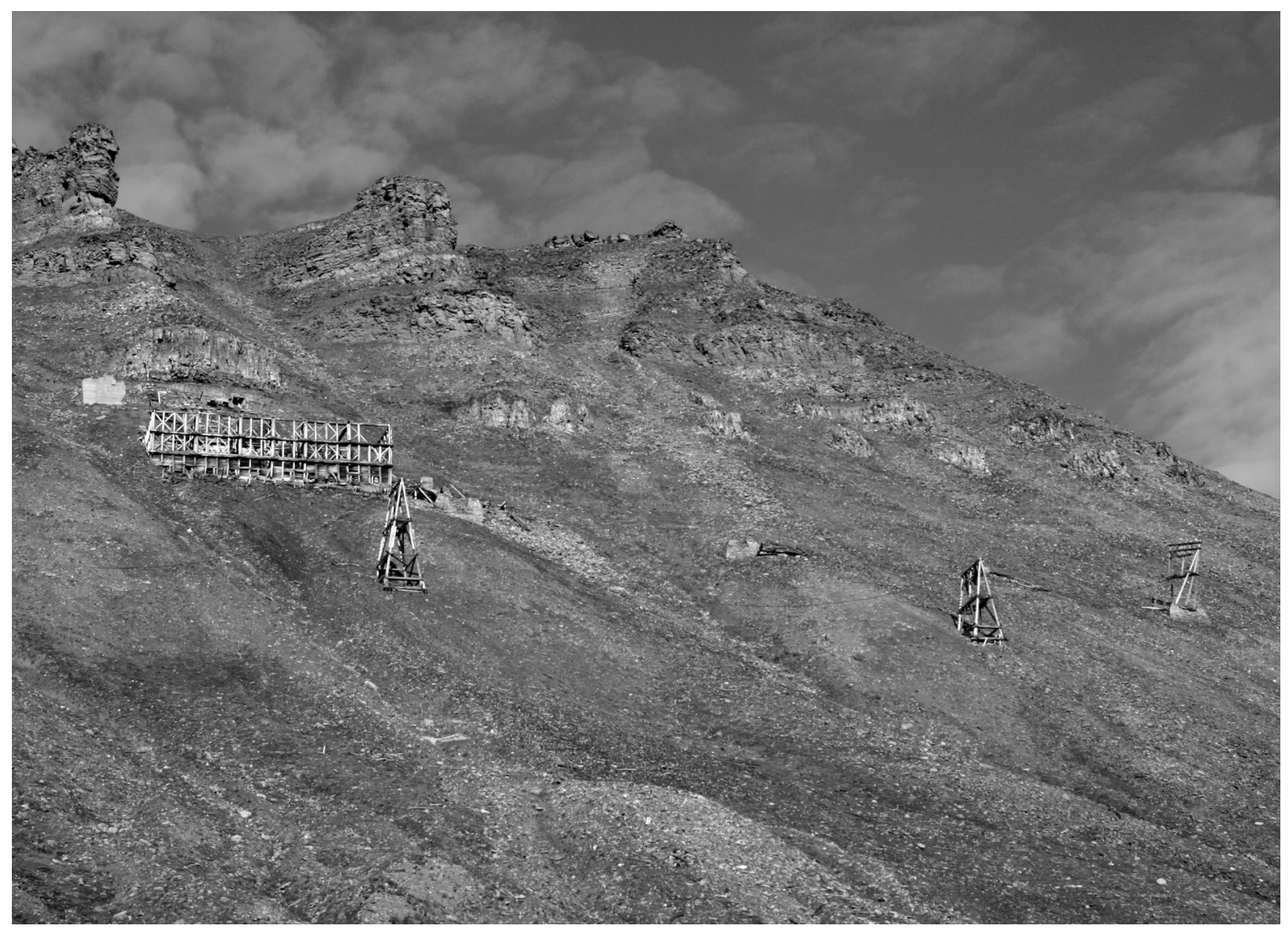

Figure 7.7 The mine 1 complex, particularly the coal hopper, stands over Longyear Valley as a historical monument. Photograph by MTU/Larry Mishkar.

The Mine 1 complex, including the mine's surface plant, the coal hopper and the aerial tramway's upper terminal remains are the most significant elements of all Arctic Coal Company remains and deserve active preservation action to retain them for future generations. These elements were at the heart of Arctic Coal Company's and Store Norske Spitsbergen Kulkompani's early operations: mining coal. They stand as an easily

467 Confirmed by LASHIPA surveys of this area made in 2004, 2007 and 2008. 
identifiable landmark over the valley and are of the most important coal-period landmarks on the archipelago. They are also a visual memorial to twenty-six miners that died when the mine exploded in 1920.468

Today the coal hopper is in danger of collapse. While it retains most of its structural fabric, the gradual slumping of the earth around it has unhinged some of its structural elements, thereby weakening it. Falling rocks from an escarpment above have the potential to hit the structure at high velocity and seriously damage it. The Sysselmannen made a preliminary assessment of the structure in 2007 and concluded that the difficult terrain and structural instability prevented stabilization. ${ }^{469}$ Based on this, the Sysselmannen has reluctantly left the hopper for eventual collapse.

The very high historical significance of the coal hopper as argued by this work suggests that the Sysselmannen should re-consider the possibilities of stabilization. The most significant aspect of the artifact is its landmark qualities that represent the history of two important companies and a tragic mine disaster. Second in importance is its historic design for function coal storage. Should the Sysselmannen again find that stabilization work for this structure in its current form is not possible, it should consider options that structurally alter the structure but retain its landmark qualities and, if possible, evidence of its former function.

\section{Conclusions}

This chapter offers an overview of the heritage significance of the Arctic Coal Company's remains on Spitsbergen to assist future planning efforts manage the remains with

468 Dole, America in Spitsbergen, ii, 434.

469 Amundsen, Birger, “Kullsilo dømt til undergang," Svalbardposten, 59(30): 4-5. 
minimal diminution of their heritage values. At the time of writing, the Environmental Protection Act, 2001, provides the legal framework for heritage and environmental issues and deems all Arctic Coal Company remains to be 'protected.' Norway has listed the entire archipelago on the tentative world heritage list for its environmental and historic values, including the remains of its coal mining history. Should the archipelago be accepted on the world heritage list, the legal heritage protections for Arctic Coal Company remains may be strengthened. The Environmental Protection Act, 2001, directs the Sysselmannen to deter actions that will reduce the historical value of protected sites but provides no definition of 'historic value,' nor does it provide mechanisms to determine that value or how changes would impact it. To fill that gap, this chapter adopts the internationally recognized framework of the Burra Charter, 1999, of Australia ICOMOS (International Council on Monuments and Sites).

The Burra Charter states that heritage significance assessment take account of aesthetic, historic, scientific, social and spiritual values associated with a site or artifact. The Arctic Coal Company's operations around Advent Bay have very high historical significance for several overlapping reasons. It was the first fully operational, industrial scale coal mining operation on the archipelago, an important historic economic activity there. The company made major contributions to the longest running, continual attempt to develop and exploit the mineral resources of Spitsbergen that progressed through three companies that built upon and incorporated their predecessors. The Arctic Coal Company left an important legacy for Spitsbergen because its successor, visible in the continuation of its human relationship at Advent Bay and in other mining companies entering Spitsbergen that looked to it as a model for development. In line with Cronon's environmental history of the Kennecott mines, the Store Norske Spitsbergen 
Kulkompani continued the Arctic Coal Company's human / nature relationship by buying its land parcels, using the same technical and settlement facilities, mining methods and some critical staff, inheriting its landscape knowledge and particularly in its adoption of much of the company's developmental plans for the future. That relationship is still visible today in the continuation of Spitsbergen's largest settlement and government center, Longyear City. The company's larger landscape strategy failed to appreciably materialize and left the minor legacy of land ownership patterns and knowledge of coal resources, of moderate historical significance.

Four seasons of archaeological survey work by MTU within the larger LASHIPA project has shown that substantial evidence remains of all Arctic Coal Company activities across the landscape. While many structures exist as ruins today, they are clearly visible on the surface and interpretable by informed observers. Enough evidence exists to show the broad range of activities the company undertook in the early twentieth century. Under the Burra Charter, this reasonably intact collection of remains has significance as a group that speaks to the entire significance of the company. Each component has significance by its association with this group and deserves protection for this reason alone.

The collection of remains were broken into smaller groups of like kind to assess their various values and provide insight into the various levels of significance and priorities for preservation, if any. Evidence of seven of eight claiming and prospecting huts used by the Arctic Coal Company have moderate significance in their association with the company's failed attempt to profit from their land claims. The majority of the company's physical interventions on the Green Harbor area is still visible today and has moderatehigh significance as its second most important mining center. Extensive remnants remain of the company's prospecting and mapping efforts around Advent Bay have high 
significance as the most in-depth commercial geological survey and mapping efforts by that time that formed part of the basis for ongoing operations there.

Old Longyear City exists as only as surface remains today but has very high significance as the first medium to large-scale mining settlement on the archipelago and because it represents the founding of Longyearbyen. The Arctic Coal Company's technical system is the most significant component of the remains because it sat at the core of the company's efforts. It is also the best surviving component of the operations, with four standing structures and extensive surface remains. Of this system, the coal mine complex and coal hopper are the most significant as they represent the true center of the operations, they stand as a prominent historic monument over Longyear Valley and are an informal memorial to twenty six miners who died there in 1920 . This mine complex is perhaps the most significant historic monument to the early coal mining era on the archipelago and deserves active preservation action to retain it for future generations. 


\section{CHAPTER 8}

\section{Conclusions}

The Arctic Coal Company attempted to encourage and profit from the transformation of Spitsbergen's undeveloped landscape into a commercial mining region, both by holding mineral lands and from its own mining operation. While it made real progress, the company ultimately failed to meet its goals because its main operations remained unprofitable and the mineral geology its other land claims proved less promising than anticipated. None-the-less, its operations by Advent Bay provided a reasonably strong footing upon which the next owner, Store Norske Kulkompani, developed a full scale, efficient operation. More than simply excavate coal, the Arctic Coal Company developed numerous instruments necessary to support a commercial mining operation in this location, such as sales and shipping strategies, mining and living facilities, and some political recognition of the right to their claims.

John Law's network approach, of the Actor Network Theory (ANT) group, provided the theoretical basis for the analysis, which proved useful in illuminating important aspects of the Arctic Coal Company's growth. Law's insistence on the variety of forces related to a network's evolution drew research attention to the social, political, commercial, environmental and technical forces surrounding the company's efforts, both in and outside Spitsbergen. The approach provided an avenue to openly address the role of the Arctic environment in the same language as other relevant factors and considering artifacts as both individual objects and a network of parts brought insights into the efficiency and robustness of the company's technical system. Above all, ANT provided a framework to examine the company's strategy to build a network that resisted dislocation, revealing that the Arctic Coal Company had made significant progress in 
developing a stable, functional network that effectively mined and sold coal but failed to be profitable.

This dissertation adapted Law's approach from analyzing a single artifact, a Portuguese galley, to a complex industrial enterprise. The adaptation presented no particular problem and simply required greater attention to the parts within the larger system. The approach, though, takes a loose view of technological change because actants can be any size and type and since Law makes few observations on technological patterns of change. That leaves researchers a wide space to adapt it towards particular research goals while limiting the theory's capacity to advocate a particular viewpoint and the ability of researchers to test it.

The Arctic Coal Company fit within and built upon many existing contextual factors surrounding Spitsbergen. It worked on western Spitsbergen where groups had exploited the archipelago's natural resources for centuries. Human interaction from hunting to geological studies since 1596 offered ample evidence on the nature of the archipelago and the location of coal there, in the form of maps, written sources and experienced people. Several teams had explored and at least two groups had specifically worked the lands that became the Arctic Coal Company's main land claim, Tract \#1. Economically, Scandinavia's industrialization increased the demand for coal and its growing northern settlements offered workers and expanded the ports nearest Spitsbergen. The archipelago's terra nullius status gave Ayer and Longyear cheap access vast quantities of coal lands, which benefited commercially risky mining efforts there, but limited their ability to defend their claims against competitors and themselves against their workforce. The establishment of the Arctic Coal Company did not match the current European political climate over Spitsbergen, over which several countries were then 
competing for control. This worked against the Arctic Coal Company when the Norwegian state acted to strengthen its claim to the archipelago, often counter to the interests of the company.

J. M. Longyear's network building efforts in the region began well before he invested in the Arctic Coal Company. He initially had interest in undeveloped iron lands of far northern Norway. Longyear and his associates considered that region in terms of its potential to function in different hypothetical commercial networks and attempted to draw together the environmental, political, technical and commercial actacts necessary to make such that a reality. They initially had little interest in Spitsbergen coal and only inspected the archipelago because they were looking for a source of coking coal, which they falsely believed Spitsbergen possessed, to supply a possible iron mining operation. Once on Spitsbergen, Longyear and his associates saw an opportunity to easily develop a coal operation that could supply the coking needs of the growing Scandinavian iron industry and the Scandinavian steaming coal market.

Arctic Coal Company Treasurer, Frederick Ayer, and President, J. M. Longyear, pursued two related goals on Spitsbergen. They financed the development a fully equipped mining operation at Advent Bay. They also attempted to encourage and profit from outside interest in the wider development of Spitsbergen's coal lands. Beyond their Advent Bay tract, they claimed three additional tracts of land around Spitsbergen's Ice Fjord and considered claiming or purchasing more, and then prospected the lands to better understand their future development potential. This land strategy matched Longyear's past approach to managing the timber and mineral lands around Lake Superior, where he gained control of huge areas of land and leased or sold them to others to develop. Longyear and the Arctic Coal Company's hopes for their three claims failed to 
be realized when prospecting revealed low-value coal veins and solicitations for their lease or sale brought few interested investors.

Much of the Arctic Coal Company's work at its mining operation on Advent Bay was typical of new American mining operations of the period. The company always used standard equipment and coal mining methods, which generally functioned adequately in the Arctic environment. The company also exhibited a typical pattern of growth for a startup mining company. In its earliest years, the company focused most on its mine and technical facilities in order to shorten the time needed to commence operations and limit capital outlay until it gained confidence in the mine's potential. Work was completed in 1909 on General Manager William Munroe’s original design, a generic mining system featuring multi-use equipment that gave the system functional flexibility. It was only on commencing full operations that year that many of the major problems facing the operation were identified. On receiving a positive account by a coal mining engineer, Ayer and Longyear invested in upgrading the whole works by expanding its range of facilities and improving weak aspects of the system, particularly the coal storage and delivery system. By the time of sale, the company had adapted the technical system to better meet local environmental and economic conditions and improved its efficiency through the use of more specialized, single-use equipment.

The Arctic Coal Company confronted numerous interrelated problems that required physical, social and economic solutions to overcome. The company largely overcame a costly and inefficient shipping system by upgrading its coal loading facilities on Spitsbergen, purchasing a new ship to lower cost and better controls its summer fleet, pursuing cheaper leasing arrangements and concentrated on meeting customer delivery expectations. Its efforts to develop an efficient, reliable and stable labor force brought 
mixed results. By introducing a contract work system and by relying on foremen to oversee daily operations and chose the labor force, the operations became more efficient and production costs fell. But the company always felt uncomfortably vulnerable to labor action. Spitsbergen's terra nullius status minimized their defense against labor action and misconduct by legal means while the use of Scandinavian labor brought with it socialist expectations in the workplace. The workforce was also highly transient and somewhat unreliable. While good pay encouraged workers to join the company, poor housing for most and difficult environmental conditions discouraged them from continuing for more than one season. By the last year of operations, the company succeeded in reaching good productivity levels and attracting a significant number of return workers.

Spitsbergen's Arctic environment did not prevent the Arctic Coal Company from utilizing typical mining approaches but profoundly influenced the enterprise's pattern of growth. Climactic conditions that froze and thawed Spitsbergen's waterways each year forced the company to have one group of workers for the winter season and another over the summer. To accommodate the freeze / thaw in its technical operations, from 1909 the company gradually built a large outdoor coal storage facility for coal extracted over the winter and an efficient coal loading facility to load ships quickly over the summer. The short summer construction season combined with the high transport cost for materials and Ayer and Longyear's restraint on spending weakened the company's ability to build some facilities and promoted an evolutionary style of growth. This is visible in the outdoor coal storage system which management gradually improved over time despite their explicit desire to develop a different system altogether. The archipelago's isolation from commercial centers was an important geographical feature that threatened the 
company's network because it added significant expense in the form of increased wages, additional transportation costs and the need to house and feed the entire workforce. The costs alone prevented the company any hope of profiting from the operations, a dislocating force in the network that the company temporarily overcame by paying for yearly losses.

The Arctic also had a strong influence on the development of Longyear City. As with the coal storage facility, the company was unable to build the quality of housing it wanted; while it built reasonable facilities for the management, it was unable to build good housing for the majority of the workforce, who lived in cramped, basic conditions. Town development was also evolutionary because planning typically occurred within one year of construction and reflected current company circumstances more than longer term planning goals. The settlement most resembles other isolated Arctic and sub-Arctic industrial settlements. The Kennecott Mill town developed at the same time and grew through the same process of gradual evolution rather than following town planning models. The use of bunkhouses, often avoided in contemporary American industrial company towns, were common in Longyear City, the Kennecott Mill Town, and in many other settlements on Spitsbergen and in the Arctic around that time. This is probably because the benefits of such a building type, including shorter construction time, less material requirements, lower construction cost and more efficient heating capacity per inhabitant in a cold climate, outweighed common concerns that bunkhouses were less attractive to workers and could encourage labor action. Longyear City's poor housing and lack of many social and recreational facilities came at the cost of a highly transient and disgruntled workforce and when the company was sold in 1916, the settlement more represented a camp than a community. 
The location of the Arctic Coal Company's operations in the European high-Arctic was fairly unusual for contemporary American mining companies who were primarily located in the Americas, particularly in North America. Of the almost one hundred American mining enterprises working outside North America to 1920, only around 25 worked outside the Americas and only one other is known to have worked in the European region. 470 The Arctic Coal Company adopted a very unusual approach to technology importation compared with contemporary American companies by adopting British and European management and equipment in its early operations. This study found only one other American company working outside the US that adopted a significant amount of non-American equipment and skilled labor. American companies had strong incentives to draw on American sources including a very strong domestic mining and manufacturing sector that offered familiar approaches and equipment. The reason the Arctic Coal Company broke from this pattern does not relate to the Arctic environment and is more a function of the people heading the organization. General Manager Munroe and President Longyear had little to no experience in coal mining but a British coal mining engineer working nearby offered the men advice and access to British men and equipment that would meet their needs. General Manager Scott Turner brought the company back towards a more typical pattern of sourcing technology when he introduced American preferred mining methods, hired more Americans for management positions and purchased most equipment from American suppliers.

The remains of the Arctic Coal Company on Spitsbergen are important historic relics and should be protected and in some cases actively preserved. The Environmental Protection Act, 2001, the Norwegian legal statute protecting Spitsbergen's environment, defines all

470 The Cyprus Mines Corporation worked in Cyprus. Lavender, The Story of Cyprus Mines Corporation. 
physical evidence of the Arctic Coal Company on Spitsbergen as protected but does not define the process of deciding appropriate actions, define heritage 'value' or provide a framework for its assessment. Under Burra Charter guidelines, ${ }^{471}$ the Arctic Coal Company has major historical significance as the first operational mining system at this northern latitude and an important part of an almost century's long effort to develop Advent Valley under three successive operations. The company had important legacy for the Archipelago as it served as a model for at least two other operations and the foundation for the Store Norske Kulkompani. Extensive evidence of almost all aspects of the company's efforts on the landscape in the form of standing structures and easily identifiable surface features that support the company's historic significance as a group, and Spitsbergen's Sysselmannen (governor) should manage them carefully for future generations. Evidence of Old Longyear City is partly obscured but should be preserved as the origins of Spitsbergen's largest settlement and administrative capital. The technical system is the best surviving and, together with the settlement, is most significant aspect of the company's activities and deserves careful protection. The standing coal hopper and mine remains are of the most notable coal-era historic landmarks on the archipelago and are worthy of active preservation.

\section{Recommendations for Future Research}

\section{Future Research Questions}

The author investigated all or parts of four archival collections on the Arctic Coal Company, which yielded the evidence necessary to provide the detailed account of the company's development provided in this dissertation. Neither all available evidence nor

471 ICOMOS Australia, The Burra Charter. 
all of the major questions were considered. Appendix A details the extent of archival research made.

Research into social aspects of Longyear City during the Arctic Coal Company's occupation would improve our understanding of the company with deeper insights into the functioning of the town and the lives of the people that lived there. Chapter 5 explains the expansion of the physical components of Longyear City, the forces that surrounded the changes and the some of the implications for those that stayed there. Based on that evidence, the chapter concluded that Longyear City represented a camp, not a town, and that its facilities were adequate to survive but not comfortable. Research into past inhabitants' attitudes towards the town could test the validity of that conclusion. The author encountered some evidence on what a few men thought of the settlement but almost nothing from the perspective of the regular Scandinavian worker. ${ }^{42}$ Since a few thousand men worked for the Arctic Coal Company, at least some written accounts of the experience are likely to have survived. Norwegian newspaper accounts of the company that claim to have interviewed returning workers provide some insights into daily life but may be at least partly biased because they run so strongly counter to company accounts of the food and conditions.

There is little evidence on how the inhabitants used the town, save a limited understanding of how the company divided them to inhabit various structures. Future research should consider how the workforce interacted with the town and surrounding landscape. Gaps remain on the internal layout of some buildings and their use, which Store Norske Kulkompani documentation or historic accounts of that company may

472 Chapter 5 references three accounts. Another comes from Theodor Georg Hornhauer, July 29 1915, Michigan Technological University Archives and Copper Country Historical Collections, Scott Turner Collection (MS-018), box CC folder 15. 
reveal. J. M. Longyear insisted that the company provide no recreation facilities or alcohol for the men, ${ }^{473}$ so how did they entertain themselves? 474 How did the workforce interact with the wider landscape in the workers time off and in simply living there? The answers to those questions are almost entirely vacant from the archival sources this project investigated. Scandinavian worker journals and letters are an ideal potential source of information to answer all of the above questions. An Arctic Coal Company list of many of its past employees may be a good starting point to sourcing that information. 475 Company lists of purchased goods, such as foodstuffs and general goods, would also be a helpful backdrop to describing daily life. ${ }^{476}$ Archaeological excavation of parts of Old Longyear City would almost certainly reveal important information on past inhabitants and forms of land use. That work, if pursued, should proceed after negotiation with Spitsbergen's Sysselmannen (governor) and should build upon the work performed by MTU with an international team of researchers working within the LASHIPA framework by continuing feature numbering systems and expanding MTU's inventory card system.

473 Letter from George Conant to W. B. Clark, June 29, 1913. Michigan Technological University Archives and Copper Country Historical Collections, Longyear Spitsbergen Collection (MS-031), box 5 , folder 6 .

474 Only one photograph has been located that shows the workers in their time off, in which there is a running race. Fred Tibbets private photograph collection.

475 Statsarkivet i Tromsø, Arctic Coal Company Collection (Privatarkiv Nr. 101), box 113 and Michigan Technological University Archives and Copper Country Historical Collections, Scott Turner Collection (MS-018), box Z folder 35, and in a letter from Scott Turner to Carl Saether, May 20th 1912, Michigan Technological University Archives and Copper Country Historical Collections, Scott Turner Collection (MS-018), box BT, folder 05 .

476 Including a list contained in a letter from Scott Turner to the Arctic Coal Company, May 4th 1912, Michigan Technological University Archives and Copper Country Historical Collections, Longyear Collection (MS-031), box 5, folder 3 and in a letter from Scott Turner to the Arctic Coal Company, May 23, 1912, Michigan Technological University Archives and Copper Country Historical Collections, Scott Turner Collection (MS-018), box A, folder 20. 
Further research into Spitsbergen's other historic mining ventures would provide an excellent base for comparing the development patterns of similar operations. This dissertation explains several models of development visible in the historic evolution of the Arctic Coal Company's works and proposes ways the Arctic environment impacted the company and presented itself in the pattern of development. Research into the development processes of other mining enterprises could test those models to understand their applicability to the wider Spitsbergen landscape and Polar environment. Researchers have investigated a number of Spitsbergen's historic mining sites and the LASHIPA group has recently made thorough archaeological surveys of significant parts of Spitsbergen's mining landscape, made a number of reports on them, and is in the process of completing a number of Master's theses and Ph.D. dissertations on them. Those larger works and future ones should make comparisons to extend their studies relevance.

Further research into historical and social significance would complete the significance assessment provided in this dissertation. The analysis of heritage significance provided in this work was based on the majority of the history associated with its remains but makes no assessment of the current social values associated with those remains, nor of the historic significance associated with later occupation and use of Arctic Coal Company constructed facilities. The significance assessment provided furnishes sufficient evidence to support the protection and preservation proposals subsequently given. As later groups, particularly the Store Norske Kulkompani, used, adapted and even expanded the Arctic Coal Company's facilities, a full heritage assessment should consider that history and its values. The Burra Charter maintains that social values are important to consider when assessing significance and considering heritage policies. Places, objects, 
structures, remains and histories have social significance when living people or groups of people hold that they are important. An investigation of social significance should consider all groups associated with the remains and the company's history as potential stakeholders by asking them if and how they find the history important and including those who value the place within decision making processes. 477 This includes descendant communities most associated with the Arctic Coal Company and the Store Norske Kulkompani, in Norway and the United States, and the communities of Spitsbergen. In the US, this would include but is not necessarily limited to descendents of J. M. Longyear, ongoing businesses of J. M. Longyear, the Michigan Technological University and the community of Marquette, Michigan. On Spitsbergen, this would include the Store Norske Kulkompani and the Longyearbyen community, amongst others. Several stakeholder groups likely exist in Norway, most likely in Trondheim and Tromsö, and amongst Arctic research groups. A survey of attitudes towards the company's history and its remains with these stakeholders is an ideal way to start this process. Research into social significance need not necessarily be extensive but should establish if and how people today find the history of the Arctic Coal Company and the early history of the Store Norske Kulkompani significant and if any particular remains of the companies are important to them.

477 Australia ICOMOS, Guidelines to the Burra Charter, article 11. 


\section{BIBLIOGRAPHY}

\section{Archival Sources}

Longyear Spitsbergen Collection (MS-031), Michigan Technological University Archives and Copper Country Historical Collections.

Scott Turner Collection (MS-018), Michigan Technical University Archives and Copper Country Historical Collections.

Keweenaw Digital Archives, <http://digarch.lib.mtu.edu/>, Michigan Technical University Archives and Copper Country Historical Collections.

Longyear Collection, J. M. Longyear Research Library, Marquette Michigan.

U. S. Department of State records, National Archives II, College Park.

United States Geological Survey Records, U.S.G.S. Headquarters, Reston, Virginia.

Arctic Coal Company Collection (Privatarkiv \#101.), Statsarkivet i Tromsø, Norway.

Store Norske Spitsbergen Kulkompani Collection, Statsarkivet i Tromsø, Norway.

Anders Beer Wilse Collection, Norsk Folkemuseum, Oslo, Norway.

Riksarkivet, Spetsbergenarkivet, Stockholm, Sweden.

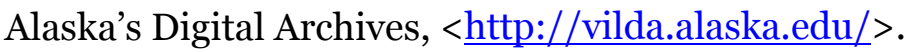




\section{Documentary Sources}

Aitken, Hugh G. J., American Capital and Canadian Resources. Cambridge, Massachusetts: Harvard University Press, 1961.

Alanen, Arnold R., "The Planning of Company Communities in the Lake Superior Mining Region," APA Journal, 45, (July 1979): 256-278.

AMAP, AMAP Assessment Report: Arctic Pollution Issues. Arctic Monitoring and Assessment Programme: Oslo, Norway, 1998.

Amundsen, Birger, “Kullsilo dømt til undergang," Svalbardposten, 59(30): 4-5.

American Geographical Society, 1903. "The Most Northern Railroad," Bulletin of the American Geographical Society 35(1):49-50.

Arlov, Thor B (ed.)., Store Norske 75 År. Longyearbyen: Store Norske Spitsbergen Kulkompani A/S, 1991.

Arlov, Thor B., Svalbards Historie 1596-1996, Oslo: Tapir Akademisk Forlag, 1996.

Arlov, Thor B., A Short History of Svalbard. Oslo: Norsk Polarinstitutt, 1989.

Armstrong, Terence, George Rogers and Graham Rowley, The Circumpolar North: A Political and Economic Geography of the Arctic and Sub-Arctic. London: Methuen \& Co. Ltd., 1978.

Arnold, Dean Alexander, American Economic Enterprises in Korea. Ph.D. Disseration Thesis. NY: Arno Press, 1976. 
Avango, Dag. Sveagruvan: Svensk Gruvhantering Mellan Industri, Diplomati Och Geovetenskap. Stockholm: Jernkontoret, 2005.

Avango, Dag., Patrick Martin, Larry Mishkar, Ian West, Miles Oglethorpe, Gustav Rosness, Susan R. Martin, Industrial Heritage in the Arctic: Research and Training in Svalbard, August 2004. Houghton, USA / Stockholm / Groningen: LASHIPA, 2006.

Avango, Dag, Ben Bekooy, Ulf Gustafsson, Louwrens Hacquebord, Cameron Hartnell, LASHIPA 2: Archaeological expedition on Svalbard August 8 - 20, 2005.Groningen, the Netherlands: The Arctic Centre: University of Groningen, 2006.

Avango, Dag, Ulf Gustafsson, Louwrens Hacquebord, Cameron Hartnell, LASHIPA 3: Third Field Campaign on Svalbard, August 7-24, 2006. Groningen: The Arctic Centre, 2006.

Avango, Dag, Ypie Aalders, Ulf Gustafsson, Hidde de Haas, Louwrens Hacquebord, Cameron Hartnell, LASHIPA 4: Archaeological Expedition on Svalbard, August 2 - 25, 2007. Groningen: The Arctic Centre, 2008.

Avango, Dag, Ypie Aalders, Seth DePasqual, Ulf Gustafsson, Hidde de Haas, Louwrens Hacquebord, Cameron Hartnell, Frigga Kruse, LASHIPA 5: Archaeological Expedition on Spitsbergen, 27 July - 17 August, 2008. Groningen: The Arctic Centre, 2008.

Berg, Roald. “A Norwegian Policy of the North before World War 1?,” Acta borealia, 1112 (1984): 5-18.

Blainey, Geoffrey, The Rush that Never Ended: A History of Australian Mining, 4th ed. Carlton, Victoria: Melbourne University Press, 1993. 
Bravo, Michael and Sverker Sörlin (eds.), Narrating the Arctic - A Cultural History of Nordic Scientific Practices. Canton: Science History Publications, 2005.

Brigham, Louise, Box Furniture: How to Make a hundred Useful Articles for the Home. New York: The Century Co., 1910.

Bruland, Kristine, ed., Technology Transfer and Scandinavian Industrialisation. NY: Berg, 1991.

Brunnström, Lasse, Kiruna - A Swedish Mining City from the Turn of the Century. Umeå, Sweden: University of Umeå, 1981.

Burt, Roger, 2000. "Innovation or Imitation? Technological Dependency in the American Nonferrous Mining industry." Technology and Culture, 41:321-347.

Buzzell, Rolfe G., Mining the Burning Hills: A History of Alaska's Suntrana Coal Mine and Townsite. Anchorage: Alaska Department of Natural Resources, 1984.

Calderón, Roberto R., Mexican Coal Mining Labor in Texas and Coahuila, 1880-1930. College Station, Texas: Texas A\&M University Press, 2000.

Capelotti, P. J., By Airship to the North Pole: An Archaeology of Human Exploration. New Jersey: Rutgers University Press, 1999.

Carey, Forests, Streams, Lakes and Resources of Northern Michigan. Marquette, Michigan: J. M. Longyear and J. M. Case, 1884.

Case, John and Shirley Schwaller, 1998. The Longyear Legacy: land, Timber, Minerals. Dallas: Horizon Communications, 1998. 
Church, Roy. The History of the British Coal Industry, Volume 3, 1830-1914: Victorian Pre-eminence. Oxford: Clarendon Press, 1986.

Crawford, Margaret, Building the Workingman's Paradise: The Design of American Company Towns. London: Verso, 1995.

Cronon, William, “Kennecott Journey: The Paths out of Town.” In Under an Open Sky: Rethinking America’s Western Past, edited by William Cronon, George Miles and Jay Gitlin. New York: W. W. Norton \& Company, 1992.

Cronon, William. Nature's Metropolis: Chicago and the Great West. New York: W.W. Norton \& Company, 1991.

Cronon, William (ed.), Uncommon Ground: Toward Reinventing Nature. New York: W. W. Norton \& Co., 1995 .

Crowell \& Murray, Inc. The Iron Ores of Lake Superior. Cleveland: The Penton Press Co., 1920.

Daunton, M.J. 1981. "Down the Pit: Work in the Great Northern and South Wales Coalfields, 1870-1914." The Economic History Review, New Series 34(4):578-597.

De Geer, Gerard, The Coal Region of Central Spitsbergen, in 'YMER', A.-B. Nordiska Bokhandeln, Stockholm, 1912.

Derksen, Richard, 1983. "Forminière in the Kasai, 1906 - 1939." African Economic History, 12: 49-65.

Dole, N., America in Spitsbergen, The Romance of an Arctic Coal-Mine, 2 vols. Boston: Marshall-Jones Company, 1922. 
Eckrose, Roy, America's Gogebic Range: The Gogebic Iron Range of Upper Michigan and Northern Wisconsin. Saxon, Wisconsin: Exploration Press, 2007.

Ellis, Richard, Men and Whales. NY: Alfred A. Knopf, 1991.

Evjen, Bjørg. Longyearbyen 1916-1975: Fra Arktisk Arbeidsplass Til Etablert Industrisamfunn? Tromsø: Universitetet Tromso, 1995.

Finney, Kenneth W., In Quest of El Dorado: Precious Metal Mining and the modernization of Honduras 188o-19oo. New York: Garland Publishing, 1987.

Finney, Kenneth V., 1979. "Rosario and the Election of 1887: the Political Economy of Mining in Honduras,” The Hispanic American Historical Review, 59(1): 81-107.

Flinn, Michael W. The History of the British Coal Industry, Volume 2, 1700 - 183o: The Industrial Revolution. Oxford: Clarendon Press, 1984.

Hounshell, David, 1984. From the American System to Mass-production, 1800-1932, Baltimore: Johns Hopkins University Press.

Fletcher, Alfred C. B., "From Job to Job Around the World. The Adventures of Two Wanderers.” The Wide World Magazine IX (1912).

Fletcher, Alfred C. B., From Job to Job Around the World. New York: Dodd, Mead \& Company, 1917.

Francaviglia, Richard V., Hard Places - Reading the Landscape of America's Historic Mining Districts. Iowa City: University of Iowa Press, 1997. 
Freshfield, Douglas W., April 1918, "British Interests in Spitsbergen," The Geographical Journal 51(4): 245-249.

Friedmann, J., Regional Development Policy: A Case Study of Venezuela. Cambridge, Massachusetts: MIT Press, 1966.

Gilbert, Cathy, Paul White, and Anne Worthington, Cultural Landscape Report: Kennecott Mill Town. Copper Center: Wrangell-St. Elias National Park/Preserve, 2001.

Governor of Svalbard, Svalbard: Experience Svalbard on Nature's own terms. Svalbard, Longyearbyen: Svalbard Reiseliv, 2006.

Grattan, C. Hartley, 1963: The Southwest Pacific to 19oo, A Modern History: Australia, New Zealand, The Islands, Antarctica. Ann Arbor, Michigan: The University of Michigan Press, 1963.

Hacquebord, L. "Dutch Cultural Heritage in the Arctic" in Barr, S. and Chaplin , P. (eds), Cultural Heritage in the Arctic and Antarctic Regions. Monuments and Sites Series VIII. Oslo: International Polar Heritage Committee, 2004.

Hacquebord, L. "European Whalers and their Relations with Pomor fur Hunters on Spitsbergen.” Paper presented at the Scientific Conference Barentsburg (Spitsbergen), Archaeological Researches in Spitsbergen and the International Polar Year, August 2022, 2006.

Hacquebord, Louwrens, "Whaling Stations as Bridgeheads for Explorations of the Arctic Regions in the Sixteenth and Seventeenth Century," International Conference on Shipping, Factories and Colonization (Brussels, 24-26 November, 1994), 289-297. 
Hacquebord, L., F. Steenhuisen and H. Waterbolk, "English and Dutch whaling trade and whaling stations in Spitsbergen (Svalbard) before 1660," International Journal of Maritime History 15(2003): 117-134.

Hammond, John Hays, The Autobiography of John Hays Hammond. Murray Hill, New York: Farrar \& Rinehart Incorporated, 1935.

Hardesty, Donald L. and Barbara J. little, Assessing Site Significance: A Guide for Archaeologists and Historians. New York: AltaMira Press, 2000.

Harland, W. B., The Geology of Svalbard. London: The Geological Society, 1997.

Harris, John R. "Law, Espionage and the Transfer of Technology from EighteenthCentury Britain." In Technological Changes: Methods and Themes in the History of Technology. Ed. Robert Fox. London: Harwood Academic Publishers, 1996.

Hartnell, Cameron and Seth DePasqual, ACC Warehouse \# 4, Feature 0.19, Unpublished Inventory Sheet. Houghon, MI: Michigan Technological University, 2007.

Hartnell, Cameron, 'Arctic Coal Company Powerhouse' inventory card, in Hartnell, Cameron, Seth DePasqual and Patrick Martin Heritage Survey of the Arctic Coal Company, Svalbard: Svalbard's Environmental Protection Fund Final Report. Houghton, MI: Michigan Technological University, 2008.

Hatton, T.J. and J.G. Williamson, 1994, "What drove the mass migrations from Europe in the late Nineteenth century?" Population and Development Review 20, 533-559.

Herzog, Werner, dir. Encounters at the End of the World, Discovery Films, 2008. 
Hoagland, Alison K., "The Boardinghouse Murders: Housing and the American ideals in Michigan's Copper Country In 1913," Perspectives in Vernacular Architecture: the Journal of the Vernacular Architecture, Forum 11 (Fall 2004).

Hoel, A., 'Spitsbergen-Bjornoykullene of Norges Braendselsforsyning. Saertryk av Teknisk Ukeblad nr. 51, 1922. S. T. nr. 14,' Michigan Technological University Archives and Copper Country Historical Collections, Longyear Spitsbergen Collection, MSo31-0403-01.

Hoel, Adolf, 1966. Svalbard's Historie 1596 - 1965. 3 vols. Oslo: Kildahls Boktrykkeri, 1966.

Holzberg, Carol S. and Maureen J. Giovannini, "Anthropology and Industry: Reappraisal and New Directions," Annual Review of Anthropology, 10 (181): 317-36o.

Hoover, Herbert, The Memoirs of Herbert Hoover: The Years of Adventure, 1874-1920 New York: The Macmillan Company, 1951.

Hoover, Herbert, Principles of Mining: Valuation, Organization and Administration; Copper, Gold, Lead, Silver, tin and Zinc. New York: McGraw-Hill Book Company, 1909.

Hoover Medal Board of Award, Scott Turner: Hoover Medalist. NY: 1957.

Huggett, Richard John, Fundamentals of Geomorphology, second edition. Routledge, 2007.

Hughes, Thomas, Networks of Power: Electrification in Western Society 1880-1930. Baltimore: The Johns Hopkins University Press, 1983. 
Hyde, Charles K., Copper for America: The United States Copper Industry from Colonial Times to the 1990s. Tucson: The University of Arizona Press, 1998.

Icelandic Annals, 1194.

ICOMOS Australia, The Burra Charter: The Australia ICOMOS charter for the conservation of places of cultural significance. Canberra, Australia: Australia ICOMOS, 1999.

Jasinski, M.E., Pomors in Grumant: Archaeological Studies of Russian Hunting Stations in Svalbard, 2 Vols. Tromso, Norway: Institute of Social Science, 1993.

Jeremy, David. Transatlantic industrial Revolution: The Diffusion of Textile Technologies Between Britain and America, 1790-1830s. Cambridge, Massachusetts: The MIT Press, 1981.

Katz, Elaine, 2005. "The Role of American Mining Technology and American Mining Engineers in the Witwatersrand Gold Mining Industry 1890 - 1910." The South African Journal of Economic History, 20(2):48-82.

Katzenellenbogen, Simon, "Cyanide and Bubbles: Patents and Technological Change in Gold and Non-Ferrous Metals Treatment" in K. Tenfelde (ed.), Sozialgeschichte des Bergbaus im 19. und 2O. Jahrundert. Munich: Verlag C. H. Beck Munchen, 1982.

Kemp, Emory L., 1993, "National Styles in Engineering: the Case of the 19th-Century Suspension Bridge," IA, The Journal of the Society for Industrial Archaeology 19(1): 2136. 
Klubock, Thomas Miller, Contested Communities: Class, Gender, and Politics in Chile’s El Teniente Copper Mine, 1904 - 1951. Durham: Duke University Press. 1998.

Lamont, James, Yachting in the Arctic Seas or Nortes of Five Voyages of Sport and Discovery in the Neighborhood of Spitzbergen and Novaya Zemlya. London: Chatto and Windus, 1876.

Landon, David and Timothy Tumberg, 1996: "Archeological Perspectives on the Diffusion of Technology: An Example from the Ohio Trap Rock Mine Site," IA: Journal for the Society of Industrial Archaeology, 22 (2): 41-57.

Lankton, Larry, Beyond the Boundaries: Life and Landscape at the Lake Superior Copper Mines 1840 - 1875. Oxford University Press, 1997.

Latour, Bruno, "On Recalling ANT" in Law, John and John Hassard. Actor Network Theory and After. Malden, MA: Blackwell, 1999.

Latour, Bruno, Science in Action: How to Follow Scientists and Engineers through Society. Cambridge, Massachusetts: Harvard University Press, 1987.

Lavender, David, The Story of Cyprus Mines Corporation. San Marino, California: The Huntington Library, 1962.

Law, John, “Technology and Heterogeneous Engineering: The Case of Portuguese Expansion” in Bijker, Wiebe E., Thomas P Hughes, and T. J. Pinch, eds., The Social Construction of Technological Systems. Cambridge, Mass: MIT Press, 1987.

Law, John and John Hassard. Actor Network Theory and After. Malden, MA: Blackwell, 1999. 
Lewchuk, Wayne, American Technology and the British Vehicle Industry. Cambridge: Cambridge University Press, 1988.

Lindqvist, Svante, Technology on Trial: The Introduction of Steam Power Technology into Sweden, 1715 - 1736. Uppsala: Almqvist and Wiksell International, 1984.

Lloyd, Trevor, 1955. "Iron Ore Production at Kirkenes, Norway," Economic Geography 31(3):211-233.

Lombard, Thomas R., The New Honduras: Its Situation, Resources, Opportunities and Prospects, Concisely Stated from Recent Personal Observations. Chicago: Brentano's, 1887.

Lund-Mathiesen, Ivar. Grubesamfunnene På Spitsbergen 1905-1917 -

Syndikaliststreiken Og Militærintervensjonen Sommeren 1917. Oslo, 1974.

Mangham, Bertrand, The First Mining in Spitsbergen, Unpublished notes transcribed by G. A. Mangham in 1993, date unknown, personal collection of G. A. Mangham.

McFadden, Terry T. and F. Lawrence Bennett, Construction in Cold Regions: A Guide for Planners, Engineers, Contractors, and Managers, third edition. New York: John Wiley and Sons, 1991.

McGhee, Robert, The Last Imaginary Place: A Human History of the Arctic World. Oxford University Press, 2005.

Menghetti, Diane, 2005. "Invention and Innovation in the Australian Non-Ferrous Mining Industry: Whose Technology?" Australian Economic History Review, 45(2):204-219. 
Metheny, Karen Bescherer, From the Miners' Doublehouse: Archaeology and Landscape in a Pennsylvania Coal Company Town. Knoxville: University of Tennessee Press, 2007.

Michigan College of Mines, Graduates of the Michigan College of Mines up to an including the class of 1909. Houghton, MI: June 1910.

Michigan Mining School: Catalogue and Prospectus, 1894-1896. Houghton, MI: The Michigan Mining School, 1896.

Moore, E. S., American Influence in Canadian Mining. Toronto, Canada: The University of Toronto Press. 1941.

Mouat, Jeremy, Metal Mining in Canada, 1840-1950. Ottawa, Canada: National Museum of Science and Technology, 2000.

Mulrooney, Margaret M, A Legacy of Coal: The Coal Company Towns of Southwestern Pennsylvania. Washington D.C.: Historic American Buildings Survey / Historic American Engineering Record, 1989.

Nasht, Simon, The Last Explorer: Hubert Wilkins, Hero of the Great Age of Polar Exploration. NY: Arcade Publishing, 2005.

Nathorst, A.G., "Beiträge zur Geologie der Bären-Insel, Spitzbergens, und des König-Karl Landes," Bulletin of the Geological Institution of the University of Uppsala 10 (1910): $261-416$.

Neatby, L. H., Conquest of the Last Frontier. NY: H. Wolff, 1966. 
O'Brien, Thomas F., 1989. "Rich beyond the Dreams of Avarice: The Guggenheims in Chile.” The Business History Review 63(1):122-159.

O’Connor, Harvey, The Guggenheims: The Making of an American Dynasty. New York: Covici Friede, 1937.

Okhuizen, Edwin, "Dutch Pre-Barentsz Maps and the Pomor Thesis about the Discovery of Spitsbergen,” Acta Borealia: A Nordic Journal of Circumpolar Societies 22(1): 21 41.

Palmer, Spencer J., 1962. "American Gold Mining in Korea's Unsan District." The Pacific Historical Review, 31(4): 379-391.

The Philippines Division of Mines, The Mineral Resources of the Philippine Islands. Manila: Bureau of Printing, and United States Philippine Commission, 1908 - 1912. Prestvold, Kristin, Isfjorden: A Journey Through the Nature and Cultural History of Svalbard. Longyearbyen, Norway: The Governor of Svalbard, Environment Section, 2003.

Preston, B. (ed.), California Gold Mill Practices, California State Mining Bureau Bulletin No. 6. Sacramento: A. J. Johnston, 1895.

Purchas, Samuel. 1906. Hakluytus Posthumus or Purchas his Pilgrimes. Vol. 14. Glasgow: James MacLehose and Sons.

Purchas, Samuel. 1906. Hakluytus Posthumus or Purchas his Pilgrimes, Contayning a History of the World in Sea Voyages and Lande Travells by Englishmen and Others. Vol. 13. Glasgow: James MacLehose and Sons. 
Quigg, Philip W., Antarctica: The Continuing Experiment. Foreign Policy Association, 1985.

Quivik, Fred, 2003. "Gold and Tailings: The Standard Mill at Bodie, California." IA, The Journal of the Society for Industrial Archaeology, 29(2): 5-28.

Rabot, Charles, October/November 1919, "The Norwegians in Spitsbergen."

Geographical Review 8(4/5): 209-226.

Rosenberg, Nathan, Exploring the Black Box: Technology, Economics, and History. Cambridge University Press, 1994.

Saward, Frederick Edward, The Coal Trade: 1906. The Coal Trade Journal, 1906.

Schmitz, Christopher, 1986. "The Rise of Big Business in the World Copper Industry 1870 - 1930." Economic History Review, 2nd ser. 39(3):392-410.

Seltzer, Curtis, Fire in the Hole: Miners and Managers in the American Coal Industry. Lexington, Kentucky: The University Press of Kentucky, 1985.

DePasqual, Seth, "Winning Coal at $78^{\circ}$ North: Mining, Contingency and the Chaíne Opératoire in Old Longyear City.” (Master's Thesis, Michigan Technological University, 2009).

Singh, Elen C., The Spitsbergen (Svalbard) Question: United States Foreign Policy, 1907-1935. Oslo: Universitetsforlaget, 1980.

Smolka, H. P., 40,ooo against the Arctic: Russia's Polar Empire. NY: William Morrow and Company, 1937. 
Smolka, H.P., "Soviet Development of the Arctic New Industries and Strategical Possibilities," International Affairs 16, 4 (1937) 564-578.

Spence, Clark C., Mining Engineers and the American West: The Lace-Boot Brigade, 1849-1933. New Haven: Yale University Press, 1970.

Spence, Clark C., "The Golden Age of Dredging: The Development of an Industry and Its Environmental Impact.” The Western Historical Quarterly 11(4, Oct., 1980): 401-414.

Starkov, Vadim F., "Methods of Russian Heritage Site Dating on the Spitsbergen Archipelago," Acta borealia 22(1):63-78.

Sternstein, Jerome L. 1969. "King Leopold II, Senator Nelson W. Aldrich, and the Strange Beginnings of American Economic Penetration of the Congo," African Historical Studies 2(2):189-204.

Sugden, David, Arctic and Antarctic: A Modern Geographical Synthesis. Totowa, New Jersey: Barnes and Noble Books, 1982.

Report of the Philippine Commission to the Secretary of War. Washington D.C.: Government Printing Office, 1900-1916.

Rickard, Thomas Arthur, Interviews with Mining Engineers. San Francisco: The Mining and Scientific Press, 1922.

Rowse, A. L., The Cousin Jacks: The Cornish in America. New York: Charles Scribner's Sons, 1969. 
Tennant, Edward W., Using ArcGIS to Create 'Living Documents' with Archaeological Date: A Case Study from Svalbard, Norway. Masters Thesis, Michigan Technological University, 2005.

Torreano, Peter F., Mesabi Miracle: The 10o-Year History of the Pillsbury-BennettLongyear Association. Hibbing, Minnesota: Sargent Land Company, 1991.

Tymms, T., 1925. "Aerial Navigation in the Arctic," The Geographical Journal 66(2):12629.

Unger, Irwin and Debi Unger, The Guggenheims: A Family History. HarperCollins, 2005 .

U.S. Dept. of Labor. Bureau of Labor Statistics. "Housing by Employers in the United States." Bulletin No. 263, Washington G.P.O., 1920.

Van Bueren, Thad M., 2004. “The "Poor Man's Mill": A Rich Vernacular Legacy.” IA, The Journal of the Society for Industrial Archeology 30(2): 5-23.

Vatten, Ole. Longyearbyen 1905-1935: Et Norsk Samfunns Oppbygging Og Utvikling. Trondheim, 1980.

Vaughan, Richard, The Arctic: A History. Phoenix Mill: Sutton Publishing, 1994.

Weed, Walter Harvey, Mines Register: Successor to the Mines Handbook and the Copper Handbook, Describing the Non-ferrous Metal Mining Companies in the Western Hemisphere. NY: W. H. Weed, 1920.

Westby, Sigurd, Store Norske Spitsbergen Kulkompani, 1916-1945, edited by Birger Amundsen. Longyearbyen, Norway: Store Norske, 2003. 
White, Paul et al. Skidoo Mine, Death Valley National Park, HAER No. CA-290.

Washington D.C.: Historic American Engineering Record, 2001.

White, Richard, The Organic Machine. New York: Hill and Wang, 1995.

Wilkins, Mira, The Emergence of Multinational Enterprise: American Business Abroad from the Colonial Era to 1914. Cambridge, Massachusetts: Harvard University Press, 1970.

Wilkins, Mira, The Maturing of Multinational Enterprise: American Business Abroad from 1914 to 1970. Cambridge, Massachusetts: Harvard University Press, 1975.

Wråkberg, Urban, "IPY Field Stations: Functions and Meanings,” in: Legacies and Change in Polar Sciences: Historical, Legal and Political Reflections on the International Polar Year, eds. Jessica M. Shadian \& Monica Tennberg. Farnham: Ashgate Publishing, 2009, 47-71.

Yost, Edna, Scott Turner: Distinguished Alumnus Award, 1966. Houghton, Michigan: Michigan Technological University Alumni Association, 1966.

\section{Internet Sources}

Encyclopedia Britannica Home Page, < http://www.britannica.com/>.

Governor of Svalbard, “The Svalbard Treaty,” October 3, 2008, $<$ http://www.sysselmannen.no/hovedEnkel.aspx?m=45301 $>$.

Humlum, Ole, "Monitoring Surface Climate Around Longyearbyen, Svalbard," UNIS, Department of Geology, CALM project page, 3 January 2006, 
$<$ http://www.unis.no/10 STUDIES/1020 Courses/Arctic Geology/ag 204 more inf o/Ole/MonitoringSurfaceClimate.htm $>$ (July 14, 2009).

Karpoff, Jonathan M. "Roald Amundsen," in Mark Nuttall (ed.), The Encyclopedia of the Arctic. Routledge, 2005.

$<$ http://faculty.washington.edu/karpoff/Research/Amundsen.pdf $>$.

LASHIPA Home Page, < $\underline{\text { http://www.lashipa.nl/>. }}$

Rana Gruber AS Home Page,

$<$ http://www.ranagruber.no/index.php/13536? wpsid=9oubeul1cgeo648dtojb1d22d4>.

Store Norske Group Homepage, <http://www.snsk.no/internet/>.

Arctic Monitoring and Assessment Programme (AMAP) Homepage, <http://amap.no/> .

\section{Historic Journals}

The Mining and Engineering Journal.

Institute of Mining and Metallurgical Transactions.

Mining and Scientific Press.

Engineering and Mining Journal.

Mining Science. 


\section{APPENDIX A}

\section{Archives and Data Sources Related to the Arctic Coal Company}

Several archives and private document collections have the potential to provide the data needed to answer the above questions. This section details the collections known to the author with descriptions of the sections examined and unexamined.

\section{Michigan Technological University Archives and Copper Country \\ Historical Collections}

○ Longyear-Spitsbergen Collection (MS-031) - 6 boxes

- Scott Turner Collection (MS-018) - 8 boxes

- Keweenaw Digital Archives, containing digital copies of most of the photographs from the Longyear Spitsbergen Collection and the Scott Turner Collection (302 photographs - $\underline{\text { http://digarch.lib.mtu.edu/ - }}$ search under 'spitzbergen.')

This project examined all the above collections in full. The Scott Turner Collection holds the most extensive documentation of the Arctic Coal Company during Scott Turner's tenure as general manager (1911-1916) of any collection examined.

\section{J. M. Longyear Research Library Archives}

- Spitsbergen Collection

- Longyear Collection

- Photo Albums

6 boxes and 2 photograph albums partly mixed with other material. Records include photographs, maps, documents and journals of J. M. Longyear when visiting 
Spitsbergen. Examined all documents on the Arctic Coal Company. The archive also holds extensive collections related to other areas of J. M. Longyear's life that may provide further context to the Arctic Coal Company's efforts on Spitsbergen.

\section{College Park US National Archives (Archives II)}

○ State Department Collections

- 1906 - 1910: Numerical File Arrangement

- 1910 - 1963: Decimal File Arrangement

Documentation related to the Arctic Coal Company is spread throughout the State Department holdings. The author examined all or almost all the records held in the Numerical File Arrangement and a fraction of those held in the Decimal File Arrangement. The collection is strongest in the political aspects of the company and the region.

\section{Statsarkivet i Tromsø}

- Arctic Coal Company Collection (No. 101)

241 Boxes and one roll of six maps. Examined in full boxes 91, 103, 105, 106, 107, Roll 58, 113, 241 and skimmed through boxes 92, 104, 133, 134, 179, 180, 182, 227. Large part of collection not examined. This collection holds the most extensive documentation of the earliest years of the company of any archive examined.

- Store Norske Kulkompani Collection (No. 73)

3924 boxes and an extensive collection of maps held in rolls. Examined very little of the collection.

○ Carl Sæther Collection (No. 112) 
23 boxes. Not examined.

\section{Nasjonalbiblioteket, Norway}

- Anders Beer Wilse Photographic Collection

151 photographs of Spitsbergen including the Arctic Coal Company and Store Norske Kulkompani. Previews available online at

http://www.nb.no/gallerinor/. Examined in full. 


\section{APPENDIX B \\ Permissions for Copyrighted Material}

\section{Terms of use for AMAP Images}

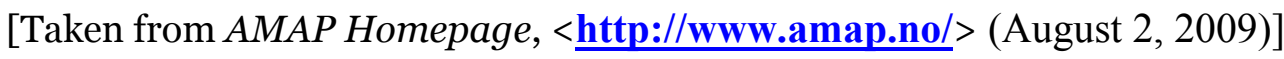

General policy regarding use and reproduction of AMAP maps and graphics by third parties

We kindly request all users of the AMAP graphics to respect the following conditions of use and reproduction.

The AMAP graphics are freely available in the form of bitmap images for use by individuals and groups involved in non-commercial enterprises, for example, students, teachers, researchers, scientists and scientific institutes, policy units, etc. engaged in producing reports, scientific or policy papers, presentation materials, etc. The bitmap images (jpeg files) can be downloaded from the AMAP website (maps and graphics database) or delivered on request (in the form of an e-mail message specifying the required images).

Under these arrangements:

- The individual or group concerned is generally expected to be interested in using single or a limited number (upto ca. 10) of the available graphics.

- No conditions are placed on use of the AMAP graphics for non-commercial purposes, however we do make a standard request that all users of the AMAP graphics make appropriate acknowledgement of the Arctic Monitoring and Assessment Programme (AMAP) as the source of the graphics and, where 
relevant (e.g. in publications), include a full citation to the AMAP report from which they are taken. The necessary citation information, together with full documentation for each graphic, including sources used, etc., is contained in the AMAP maps and graphics database.

Organizations engaged in commercial ventures who wish to use or reproduce selected AMAP graphics are requested to contact AMAP with details of the intended use of the graphics, arrangements for acknowledgment/citation of the source, and if appropriate, compensation (financial or in-kind) for permission to use the graphics. Vector graphic files (e.g., eps files) are available and can be requested from AMAP, for example, to meet requirements for high quality printed reproduction.

Users interested in reproducing AMAP graphics in electronic documents are subject to the same basic conditions applicable in the case of printed copies of the graphics. However, in the case of re-use of the AMAP graphics in the construction of websites, the following additional consideration applies. In general, AMAP is reluctant to see the AMAP graphics used in applications that have a degree of duplication or overlap with the objectives and services provided by the AMAP website. In such cases, it is generally preferred that other websites wishing to utilise to the AMAP graphics do so by inserting appropriate links to the AMAP website pages rather than inserting copies of the AMAP graphics. Part of the reason for this is to ensure that maintenance of the AMAP graphics (correction of errors, provision of updated versions of graphics and data, etc) can be accomplished without a proliferation of outdated or erroneous materials on the web. If you have any questions concerning the above, please contact us by sending an e-mail to s.wilson@inter.nl.net 


\title{
Permission to use Norsk Folkemuseum Image
}

\author{
THE NORWEGIAN MUSEUM OF CULTURAL HISTORY
}

Material: Please do not mind piont 2 in the contract, Photo. Wilse, Norsk Folkemuseum, Oslo. NF. W $09360+66,09401,05523+24+25+28,10578+80+81$ og 10617

Purpose: For research purposes and master-degrees small printrun only.

Special terms :

Production costs each photo JPG-files e-mail: Each photo NOK 85, or 170,- and one time NOK 100.- in expedition fee. There is no usage fee to be paid.

We have 2-3 weeks normal delivery time. If you want it at once, please double the production costs. In that case we can deliver within 2-3 days after we have received the contract with your signature. Please do not pay in advance, but wait for the invoice.

For all other use please contact the museum for permission.

The following general terms apply:

1) The photos may only be used for the purpose agreed upon.

2) The $\mathrm{CD}$ are to be returned as soon as possible

3) The name of the museum must be mentioned and also the name of the photographer if it is known. It will then be written in the contract under material.

4) The usage fee will be charged when the museum gets the photos/CDs in return with information of use / no use. Please do not pay in advance

5) .According to the Norwegian law, the user must show due care that persons portrayed will not be injured or portrayed in a negative manner.

6) Please sign one copy and return to us. The photos are not released before the contract is signed by both parts

Place and date:

Oslo 25/04-07

Liv Bentsborg

Norsk Folkemuseum

Museumsveien 10

0286 Oslo

Norway

Fax: +4722123777

e-mail: liv.bentsborg@norskfolkemuseum.no

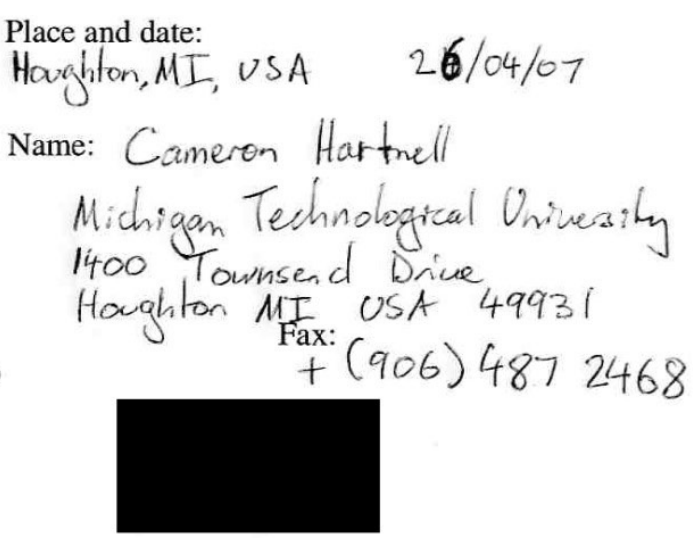

